ORNL -6605

DE93 000494

Health and Safety Research Division

\title{
HEALTH AND SAFETY PROCEDURES MANUAL FOR HAZARDOUS WASTE SITES
}

\section{J. E Thate}

\section{Prepared by}

Pollutant Assessments Group

Oak Ridge National Laboratory

Grand Junction, Colorado

Date Published: September 1992

Prepared by the

Oak Ridge National Laboratory

Oak Ridge, TN 37831-6285

managed by

MARTIN MARIETTA ENERGY SYSTEMS, INC.

for the

U.S. DEPARTMENT OF ENERGY 
MARTIN MARIETTA

ENERGY SYSTEMS, INC.

Oak Ridge National Laboratory
Pollutant Assessments Group

Health and Safety

Procedures Manual
Front Matter

Date 4/92

Page iii of xxii

SUBJECT: CONTENTS

\section{CONTENTS}

LIST OF TABLES $\ldots \ldots \ldots \ldots \ldots \ldots \ldots \ldots \ldots \ldots \ldots \ldots \ldots \ldots \ldots \ldots$

LIST OF FIGURES $\ldots \ldots \ldots \ldots \ldots \ldots \ldots \ldots \ldots \ldots \ldots \ldots \ldots \ldots \ldots \ldots$

ACKNOWLEDGMENTS $\ldots \ldots \ldots \ldots \ldots \ldots \ldots \ldots \ldots \ldots \ldots \ldots \ldots \ldots \ldots$

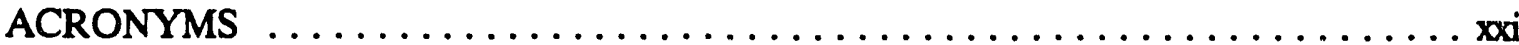

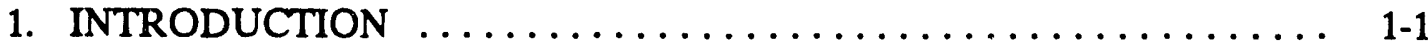

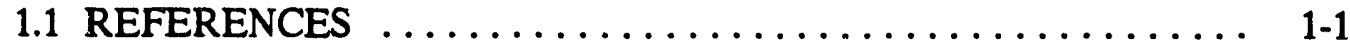

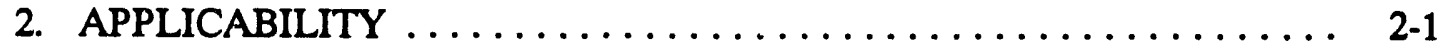

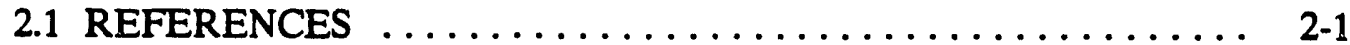

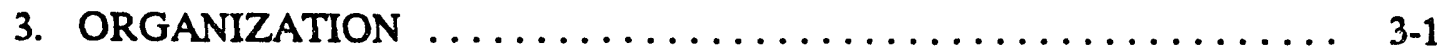

3.1 PURPOSE .........................

3.2 APPLICABILITY . . . . . . . . . . . . . . . .

3.3 CHEMICAL PROJECTS MANAGER ............... 3-1

3.4 SITE PROJECT MANAGER .................. $3-2$

3.5 SITE SAFETY AND HEALTH OFFICER . . . . . . . . . . $3-2$

3.6 PROJECT PERSONNEL $\ldots \ldots \ldots \ldots \ldots \ldots \ldots \ldots \ldots \ldots \ldots . \ldots \ldots$

3.7 REFERENCES $\ldots \ldots \ldots \ldots \ldots \ldots \ldots \ldots \ldots \ldots \ldots \ldots \ldots . \ldots \ldots$

4. MEDICAL PROGRAM $\ldots \ldots \ldots \ldots \ldots \ldots \ldots \ldots \ldots \ldots \ldots \ldots$ 4-1

4.1 PURPOSE $\ldots \ldots \ldots \ldots \ldots \ldots \ldots \ldots \ldots \ldots \ldots \ldots$ 4-1

4.1.1 Routine Health Care $\ldots \ldots \ldots \ldots \ldots \ldots \ldots \ldots \ldots$ 4-1

4.1.2 Emergency Medical Care .................. 4-1

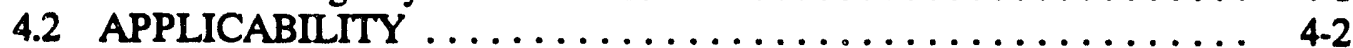

4.2.1 Health Records ....................... 4-2

4.2.2 Rules of Confidentiality .................. 4-2

4.2.3 Program Participation ..................... 4-3

4.2.4 Disclosure Agreement . . . . . . . . . . . . . . . . 4. 4.3

4.2.5 Monitoring Program $\ldots \ldots \ldots \ldots \ldots \ldots \ldots \ldots \ldots \ldots$ 4-3

4.2 .6 Examinations $\ldots \ldots \ldots \ldots \ldots \ldots \ldots \ldots \ldots \ldots \ldots \ldots . \ldots \ldots$

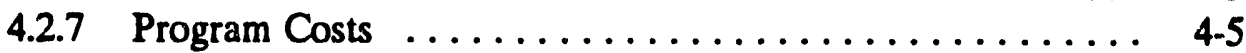

4.2.8 Examination Content $\ldots \ldots \ldots \ldots \ldots \ldots \ldots \ldots \ldots \ldots \ldots . \ldots \ldots$ 4-5

4.2.8.1 Medical history $\ldots \ldots \ldots \ldots \ldots \ldots \ldots \ldots \ldots$ 4-6

4.2.8.2 Privacy statement $\ldots \ldots \ldots \ldots \ldots \ldots \ldots \ldots . \ldots 4$ 4.6

4.2.8.3 Diagnostic tests ................. 4-6

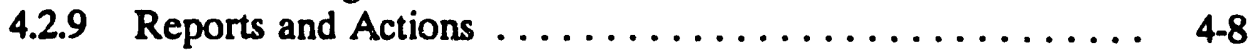

4.3 STRESS $\ldots \ldots \ldots \ldots \ldots \ldots \ldots \ldots \ldots \ldots \ldots \ldots . \ldots \ldots$ 4-8

4.4 REFERENCES $\ldots \ldots \ldots \ldots \ldots \ldots \ldots \ldots \ldots \ldots \ldots \ldots \ldots .8 \ldots \ldots \ldots$ 
MARTIN MARIETTA

ENERGY SYSTEMS, INC.

Oak Ridge National Laboratory
Pollutant Assessments Group

Health and Safety

Procedures Manual
Front Matter

Date $4 / 92$

Page iv of xxii

SUBJECT: CONTENTS

5. TOXIC PROPERTIES OF HAZARDOUS MATERIALS $\ldots \ldots \ldots \ldots \ldots$ 5-1

5.1 PURPOSE .......................... $5-1$

5.2 APPLICABILITY $\ldots \ldots \ldots \ldots \ldots \ldots \ldots \ldots \ldots \ldots \ldots \ldots$ 5-1

5.2.1 Toxicological Determination ............... $5-2$

5.2 .2 Dependent Variables .................... 5-2

5.3 HAZARDOUS MATERIALS CHARACTERISTICS . . . . . . . . 5-2

5.3 .1 Systemic Poisons . . . . . . . . . . . . . . . . . . 5-2

5.3 .2 Asphyxiants ...................... $5-4$

5.3.2.1 Simple asphyxiants .............. 5-5

5.3.2.2 Chemical asphyxiants ............. 5-5

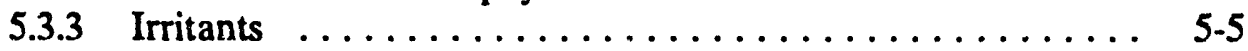

5.3 .4 Allergic Sensitizers $\ldots \ldots \ldots \ldots \ldots \ldots \ldots \ldots \ldots \ldots \ldots$

5.3.5 Carcinogens, Mutagens, and Teratogens .......... 5-7

5.3.6 Radiation Standards ... . . . . . . . . . . . . . . . . 5 5-8

5.4 OTHER HAZARDOUS CONSIDERATIONS $\ldots \ldots \ldots \ldots \ldots \ldots$ 5-8

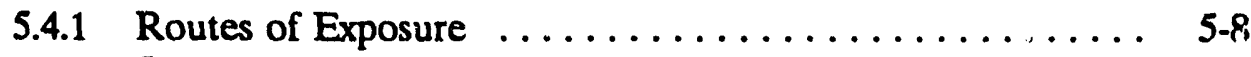

5.4.1.1 Exterior organs $\ldots \ldots \ldots \ldots \ldots \ldots \ldots \ldots \ldots . \ldots \ldots$

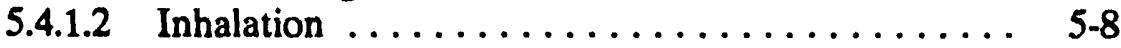

5.4 .1 .3 Ingestion $\ldots \ldots \ldots \ldots \ldots \ldots \ldots \ldots \ldots \ldots \ldots$

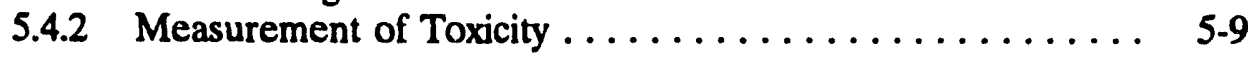

5.4.2.1 Dose response .................. 5-9

5.4 .2 .2 Data analysis $\ldots \ldots \ldots \ldots \ldots \ldots \ldots \ldots \ldots$ 5-9

5.4.2.3 Dose rate concerns ................ 5-10

5.4.2.4 Practical considerations ............. 5-10

5.5 CALCULATION OF EXPOSURE LIMITS .......... 5-11

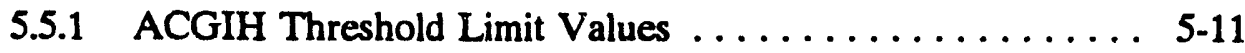

5.5.2 Time-Weighted Averages (TWA) ........... 5-11

5.5.3 TVLs Designated with "Skin" Notation .......... 5-12

5.3 .4 Excursions ...................... 5-12

5.5 .5 Mixture TLV .................... 5-13

5.5.5.1 Mineral Dust and Nuisance Dust TLV ...... 5-15

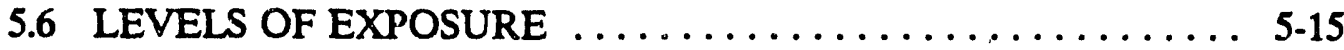

5.6.1 Protection Factors ................... 5-15

5.6 .2 Lower Flammable Limit $\ldots \ldots \ldots \ldots \ldots \ldots \ldots \ldots \ldots$ 5.15

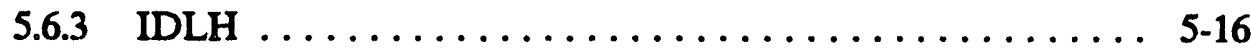

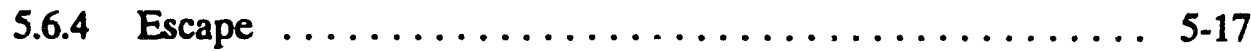

5.7 REFERENCES ...................... $5-17$

6. SITE-SPECIFIC HEALTH AND SAFETY WORK PLAN $\ldots \ldots \ldots \ldots \ldots$ 6-1

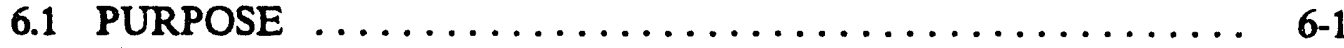

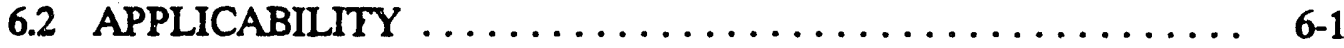

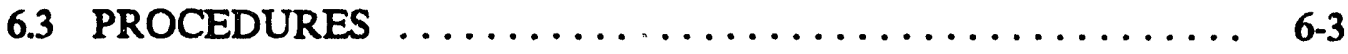


MARTIN MARIETTA ENERGY SYSTEMS, INC. Oak Ridge National Laboratory
Pollutant Assessments Group

Health and Safety

Procedures Manual
Front Matter

Date 4/92

Page $v$ of xxii

SUBJECT: CONTENTS

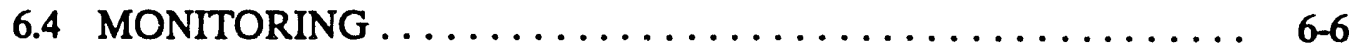

6.4 .1 Monitoring Requirements ............... 6-6

6.4 .2 Monitoring Schedule .................... 6-6

6.4.2.1 Instrument calibration . . . . . . . . . . . . 6-8

6.4.2.2 Background readings ................ 6-8

6.4.2.3 Recording environmental exposure levels ..... 6 6-8

6.5 LEVELS OF PROTECTION .................. 6-9

6.6 REFERENCES ........................ 6-9

7. RESPIRATORY PROTECTION $\ldots \ldots \ldots \ldots \ldots \ldots \ldots \ldots \ldots \ldots$ 7-1

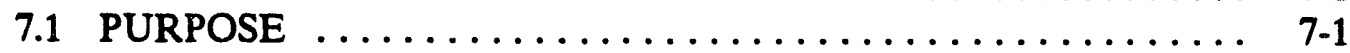

7.2 APPLICABILITY . . . . . . . . . . . . . .

7.2.1 Supervisors of Respirator Users $\ldots \ldots \ldots \ldots \ldots \ldots \ldots \ldots$ 7-2

7.2.2 Division Safety Officers ................ 7.2

7.3 METHODS OF PROTECTION $\ldots \ldots \ldots \ldots \ldots \ldots \ldots \ldots \ldots \ldots$ 7-2

7.3.1 Legal Requirements ................... 7-2

7.3.2 Respirator Control Measures .............. 7-3

7.4 AIR-PURIFYING RESPIRATORS $\ldots \ldots \ldots \ldots \ldots \ldots \ldots \ldots \ldots$

7.4.1 Respirator Use Requirements .............. 7-4

7.4.2 Types of Air-Purifying Respirators ............. $7-4$

7.4.3 Donning of Respirators .................. 7.8

7.4 .4 Escape Mask Use ....................... 7-9

7.4.5 Respirator Fit-Testing ................... 7-9

7.4.6 Stage I Fit-Testing $\ldots \ldots \ldots \ldots \ldots \ldots \ldots \ldots \ldots \ldots \ldots \ldots$

7.4.6.1 Positive-pressure sealing test $\ldots \ldots \ldots \ldots \ldots \ldots 7-11$

7.4.6.2 Negative-pressure sealing test $\ldots \ldots \ldots \ldots \ldots \ldots 7-11$

7.4.7 Stage II Fit-Testing . . . . . . . . . . . . . . 7-11

7.4.7.1 Isoamyl acetate test $\ldots \ldots \ldots \ldots \ldots \ldots \ldots \ldots 7-12$

7.4.7.2 Irritant smoke (stannic chloride) test ...... 7-13

7.5 FIT-TESTING RESPIRATOR EXERCISE $\ldots \ldots \ldots \ldots \ldots \ldots \ldots$ 7-14

7.5.1 Fit-Testing Personnel $\ldots \ldots \ldots \ldots \ldots \ldots \ldots \ldots \ldots \ldots$ 7-14

7.5.2 Fit-Test Selection ................... 7-14

7.6 RESPIRATOR INSPECTION AND MAINTENANCE $\ldots \ldots \ldots .7$ 7-16

7.6.1 Respiratory Concerns ................... 7-16

7.6.2 Inspection for Defects ................ 7-16

7.6.3 Office Inspection $\ldots \ldots \ldots \ldots \ldots \ldots \ldots \ldots \ldots \ldots .16 \ldots \ldots$

7.6.4 Field Inspection $\ldots \ldots \ldots \ldots \ldots \ldots \ldots \ldots \ldots \ldots \ldots$

7.6.4.1 Facepiece .................... 7-17

7.6.4.2 Headgear .................... . 7-17

7.6.4.3 Exhalation valve $\ldots \ldots \ldots \ldots \ldots \ldots \ldots \ldots . \ldots .7-17$

7.6.4.4 Air purifying elements .............. 7-17

7.6.5 SCBA Care and Cleaning $\ldots \ldots \ldots \ldots \ldots \ldots \ldots \ldots \ldots$ 7-18 
MARTIN MARIETTA

ENERGY SYSTEMS, INC.

Oak Ridge National Laboratory
Pollutant Assessments Group

Health and Safety

Procedures Manual
Front Matter

Date 4/92

Page vi of xxii

\section{SUBJECT: CONTENTS}

7.6.5.1 Preliminary inspection $\ldots \ldots \ldots \ldots \ldots \ldots \ldots$ 7-18

7.6.5.2 Backpack and harness assembly .......... 7-18

7.6.5.3 Cylinder and cylinder valve assembly ........ 7-19

7.6.5.4 Regulator and high-pressure hose ......... 7-19

7.6.5.5 Facepiece and corrugated breathing tube ..... 7-20

7.6.5.6 Storage of units $\ldots \ldots \ldots \ldots \ldots \ldots \ldots \ldots \ldots$ 7-20

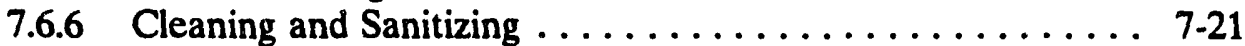

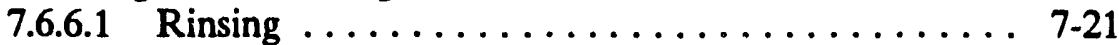

7.6.6.2 Drying ................... 7-21

7.6.6.3 Reassembly and inspection ........... 7.22

7.6.6.4 Maintenance and repair ............. 7-22

7.6.6.5 Respiratory storage ............... 7-22

7.7 REFERENCES . . . . . . . . . . . . . . . . . . 7-23

8. STANDARD OPERATING PROCEDURES $\ldots \ldots \ldots \ldots \ldots \ldots \ldots \ldots$ 8-1

8.1 PURPOSE $\ldots \ldots \ldots \ldots \ldots \ldots \ldots \ldots \ldots \ldots \ldots \ldots \ldots \ldots . \ldots \ldots \ldots$

$8.2 \quad$ APPLICABILITY ........................ 8-1

8.3 EMERGENCY RESPONSE .................... 8-1

8.3.1 Site Emergency Personnel . . . . . . . . . . . . .

8.3.2 Acute Hazardous Material Exposures .............. 8-2

8.3.3 Personnel Notification . . . . . . . . . . . . . . . . . 8-2

8.3.4 Emergency Contacts ....................... 8-2

8.3.5 Emergency Procedures ................... 8-3

8.4 HEALTH AND SAFETY CONTACT $\ldots \ldots \ldots \ldots \ldots \ldots \ldots \ldots$.

8.5 TRAINING ........................... 8-5

8.5.1 All Site Workers ..................... 8-5

8.5 .2 Additional Training ................... 8-5

8.5.3 Training Checklist . . . . . . . . . . . . . . . . . 8-7

8.5.4 Task Training $\ldots \ldots \ldots \ldots \ldots \ldots \ldots \ldots \ldots \ldots . . \ldots \ldots$

8.5.5 Rescue Training . . . . . . . . . . . . . . . . 8 8-7

8.5.6 Site Visitors . . . . . . . . . . . . . . . . . . . 8-7

8.5.7 Subcontractor Personnel . . . . . . . . . . . . . . . 8-8

8.5 .8 PSI Training $\ldots \ldots \ldots \ldots \ldots \ldots \ldots \ldots \ldots \ldots \ldots \ldots . . \ldots \ldots$

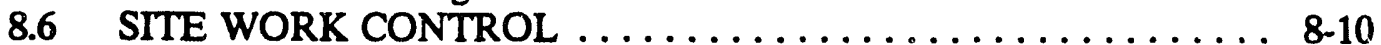

8.6.1 Site Entry Authorization ................... 8-10

8.6.2 Initial Site Determination Procedures ............ 8-10

8.6.2.1 Performing tasks in a confined space ........ 8-11

8.6.2.2 Rescue training for confined space ....... 8-12

8.6 .3 Site Safety Equipment ................. 8-12

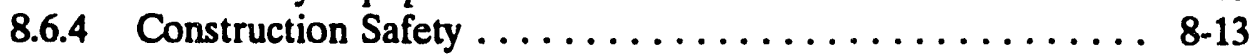

8.6 .5 Monitoring Well Safety $\ldots \ldots \ldots \ldots \ldots \ldots \ldots \ldots \ldots . \ldots .14$

8.6 .6 Slope Sampling Safety $\ldots \ldots \ldots \ldots \ldots \ldots \ldots \ldots \ldots$. $\ldots \ldots$ 
MARTIN MARIETTA

ENERGY SYSTEMS, INC.

Oak Ridge National Laboratory
Pollutant Assessments Group

Health and Safety

Procedures Manual
Front Matter

Date $4 / 92$

Page vii of xxii

\section{SUBJECT: CONTENTS}

8.6.7 Excavation Requirements $\ldots \ldots \ldots \ldots \ldots \ldots \ldots \ldots \ldots$ 8-15

8.6 .8 Water Safety . . . . . . . . . . . . . . . . . 8.16

8.6 .9 Noise Control $\ldots \ldots \ldots \ldots \ldots \ldots \ldots \ldots \ldots \ldots \ldots \ldots \ldots$ 8-16

8.6.10 Radio Control . . . . . . . . . . . . . . . . 8 8-16

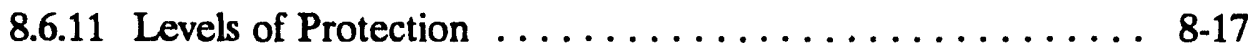

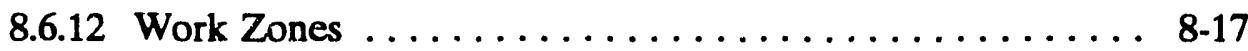

8.6.12.i Zone 1: Exclusion zone ............ 8-17

8.6.12.2 Zone 2: Contamination reduction zone ..... 8-19

8.6.12.3 Zone 3: Support zone . ........... 8-19

8.6.13 Worker Safety Procedures . . . . . . . . . . . . 8-20

8.7 DECONTAMINATION $\ldots \ldots \ldots \ldots \ldots \ldots \ldots \ldots \ldots \ldots \ldots . . \ldots .21$

8.7.1 Personnel Decontamination $\ldots \ldots \ldots \ldots \ldots \ldots \ldots \ldots$ 8-21

8.7.2 Equipment Decontamination ............... 8-22

8.7.3 Sample Container Decontamination $\ldots \ldots \ldots \ldots \ldots \ldots$ 8-23

8.7.4 Waste Disposal ..................... 8-23

8.7.5 Contamination Reduction Corridor .............. 8-24

8.7.6 Medical Emergency Decontamination . . . . . . . . . 8-24

8.8 CONTINGENCY PLANNING $\ldots \ldots \ldots \ldots \ldots \ldots \ldots \ldots \ldots . . \ldots .24$

8.8.1 Key Personnel . . . . . . . . . . . . . . . . 8-24

8.8.2 Emergency Evacuation Procedures ... . . . . . . . . 8 8-24

8.8.3 Nonroutine Occurrences . . . . . . . . . . . . . 8-24

8.9 RECORDKEEPING $\ldots \ldots \ldots \ldots \ldots \ldots \ldots \ldots \ldots \ldots \ldots . . \ldots \ldots$

8.10 EMERGENCY PLANNING . . . . . . . . . . . . . . .

8.10.1 Emergency Medical Services . . . . . . . . . . . 8-25

8.10.2 On-Site First Aid Preparations ............. 8-25

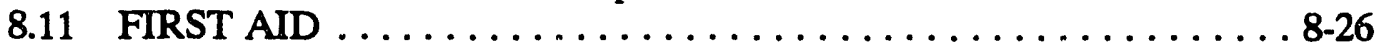

8.11.1 Accident/Incident Assessment . . . . . . . . . . 8-26

8.11 .2 Vital Signs $\ldots \ldots \ldots \ldots \ldots \ldots \ldots \ldots \ldots \ldots \ldots \ldots \ldots . \ldots . \ldots \ldots$

8.11.3 Pulmonary Emergency . . . . . . . . . . . . . . 8-27

8.12 HEAT STRESS PREVENTION . . . . . . . . . . . . 8 8-27

8.12.1 Identification and Treatment $\ldots \ldots \ldots \ldots \ldots \ldots \ldots \ldots$ 8-27

8.12.2 Prevention of Heat Stress . . . . . . . . . . . . 8-29

8.12.3 Heat Stress Monitoring . . . . . . . . . . . . . . 8-29

8.13 COLD STRESS PREVENTION $\ldots \ldots \ldots \ldots \ldots \ldots \ldots \ldots \ldots . . \ldots .30$

8.13 .1 Cold Injuries $\ldots \ldots \ldots \ldots \ldots \ldots \ldots \ldots \ldots \ldots \ldots . \ldots \ldots \ldots$

8.13.2 Systemic Cold Injuries $\ldots \ldots \ldots \ldots \ldots \ldots \ldots \ldots \ldots \ldots$ 8-33

8.14 FIRST AID EQUIPMENT $\ldots \ldots \ldots \ldots \ldots \ldots \ldots \ldots \ldots . . \ldots \ldots$

8.15 ADVERSE WEATHER OPERATIONS $\ldots \ldots \ldots \ldots \ldots \ldots .8 .35$

8.15.1 Preliminary Assessment $\ldots \ldots \ldots \ldots \ldots \ldots \ldots \ldots \ldots$ 8-36

8.15.2 Scheduling $\ldots \ldots \ldots \ldots \ldots \ldots \ldots \ldots \ldots \ldots \ldots \ldots \ldots \ldots \ldots$

8.15 .3 Lightning Storms $\ldots \ldots \ldots \ldots \ldots \ldots \ldots \ldots \ldots \ldots \ldots . \ldots \ldots$

8.15 .4 Tornadoes $\ldots \ldots \ldots \ldots \ldots \ldots \ldots \ldots \ldots \ldots \ldots$ 8.37 
MARTIN MARIETTA ENERGY SYSTEMS, INC.

Oak Ridge National Laboratory
Pollutant Assessments Group

Health and Safety

Procedures Manual
Front Matter

Date 4/92

Page viii of xxii

\section{SUBJECT: CONTENTS}

8.15.5 Site Access Maintenance . . . . . . . . . . . . . . 8-37

8.15 .6 Equipment and Supplies $\ldots \ldots \ldots \ldots \ldots \ldots \ldots \ldots \ldots$ 8-38

8.16 WOUND CARE . . . . . . . . . . . . . . . . . . . 8-38

8.16.1 Surface Wounds ................... 8-38

8.16.2 Deep Wounds and Serious Burns ............. 8-39

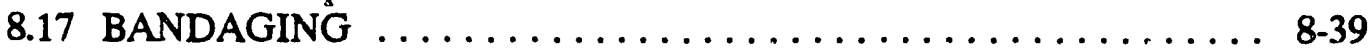

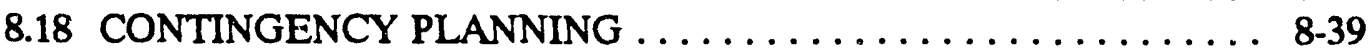

8.19 POTENTIAL HAZARDS $\ldots \ldots \ldots \ldots \ldots \ldots \ldots \ldots \ldots \ldots \ldots . \ldots \ldots$

8.19 .1 Accidents . . . . . . . . . . . . . $\ldots \ldots \ldots$

8.19.2 Contact and/or Ingestion of Hazardous Materials . . . . . 8-41

8.19.3 Personal Protective Clothing . . . . . . . . . . . 8-41

8.19 .4 Explosion Hazards $\ldots \ldots \ldots \ldots \ldots \ldots \ldots \ldots \ldots \ldots \ldots$ 8.42

8.19 .4 Fire $\ldots \ldots \ldots \ldots \ldots \ldots \ldots \ldots \ldots \ldots \ldots . \ldots \ldots$. 4.43

8.20 EVACUATION PROCEDURES $\ldots \ldots \ldots \ldots \ldots \ldots \ldots \ldots \ldots . \ldots .43$

8.20 .1 Withdrawal Upwind $\ldots \ldots \ldots \ldots \ldots \ldots \ldots \ldots \ldots \ldots \ldots . \ldots .44$

8.20.2 Site Evacuation . . . . . . . . . . . . . . . 8-44

8.20 .3 Evacuation of Surrounding Area $\ldots \ldots \ldots \ldots \ldots \ldots \ldots . . . .44$

8.20 .4 Exclusion Zone Reentry ................... . 8-45

8.20.5 Emergency Reporting Requirements ... . . . . . . . . . 8 8-45

8.20 .6 Ordnance Materials ................... 8-45

8.20.7 Illumination Recommendations . . . . . . . . . . . . 8 8-46

8.21 REFERENCES ....................... 8-46

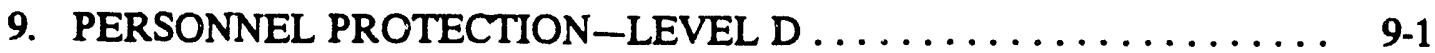

9.1 PURPOSE ............................. 9-1

9.2 APPLICABILITY $\ldots \ldots \ldots \ldots \ldots \ldots \ldots \ldots \ldots \ldots \ldots \ldots . \ldots \ldots$

9.3 PROCEDURES $\ldots \ldots \ldots \ldots \ldots \ldots \ldots \ldots \ldots \ldots \ldots \ldots \ldots \ldots$ 9-1

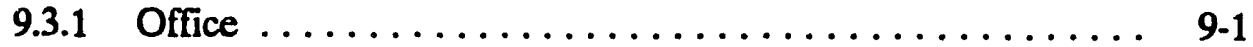

9.3.2 Field $\ldots \ldots \ldots \ldots \ldots \ldots \ldots \ldots \ldots \ldots \ldots \ldots \ldots \ldots$

9.4 OPERATION ..........................

9.5 LEVEL D+ PROTECTION ................... 9-4

9.6 LEVEL D+ EQUIPMENT DECONTAMINATION . . . . . . . . 9-6

9.7 POSTOPERATION $\ldots \ldots \ldots \ldots \ldots \ldots \ldots \ldots \ldots \ldots \ldots . \ldots \ldots$. 9.7

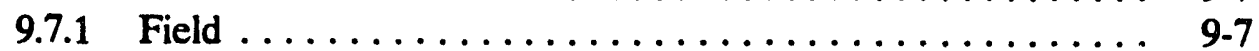

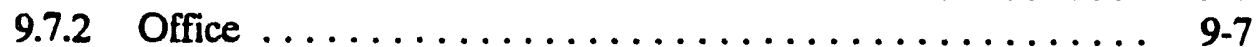

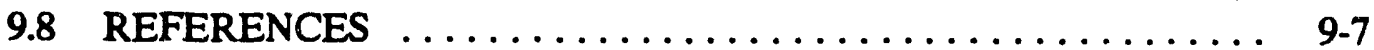

10. PERSONNEL PROTECTION-LEVEL C . . . . . . . . . . 10-1

10.1 PURPOSE ........................... 10.1

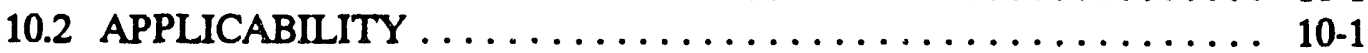

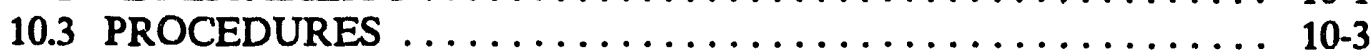

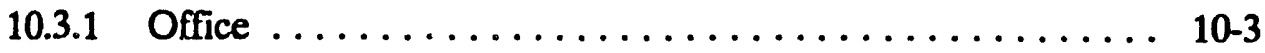


MARTIN MARIETTA

ENERGY SYSTEMS, INC.

Oak Ridge National Laboratory
Pollutant Assessments Group

Health and Safety

Procedures Manual
Front Matter

Date 4/92

Page ix of xxii

\section{SUBJECT: CONTENTS}

10.3.2 Field $\ldots \ldots \ldots \ldots \ldots \ldots \ldots \ldots \ldots \ldots \ldots \ldots \ldots \ldots$ 10-3

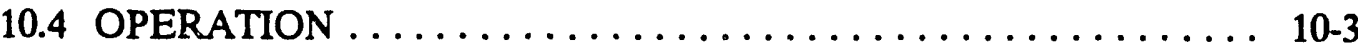

10.4.1 Maximum Decontamination Measures ............ 10-3

10.4.2 Modification of Maximum Decontamination Measures ... 10-10

10.4.3 Minimum Decontamination Measures . . . . . . . . . . . 10-10

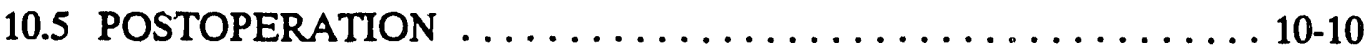

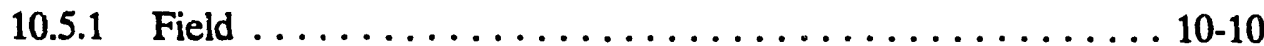

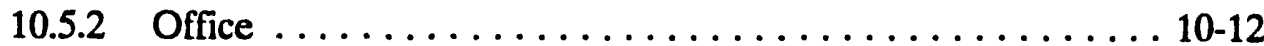

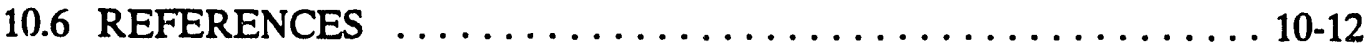

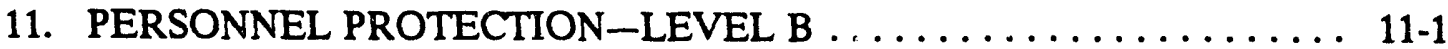

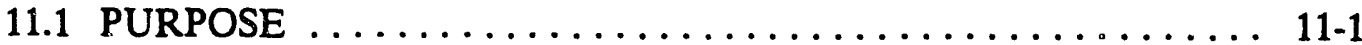

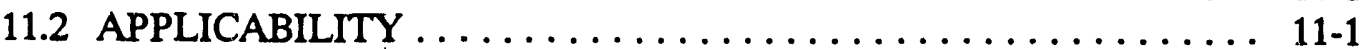

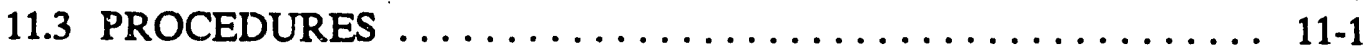

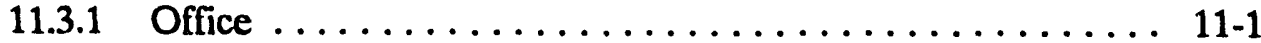

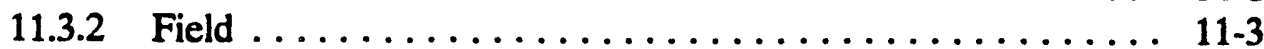

11.4 OPERATION ......................... $11-6$

11.4.1 Maximum Decontamination Measures ............ 11-6

11.4.2 Modification of Maximum Decontamination Measures .... 11-6

11.4.3 Minimum Decontamination Measures .............. 11-12

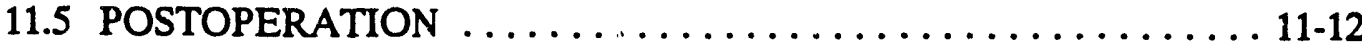

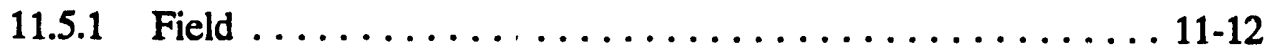

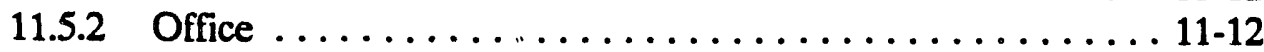

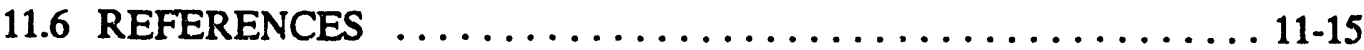

12. PERSONNEL PROTECTION_LEVEL A ............... 12-1

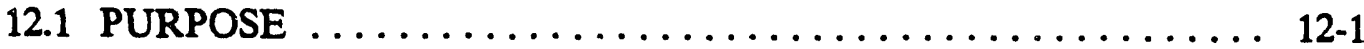

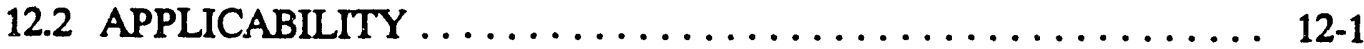

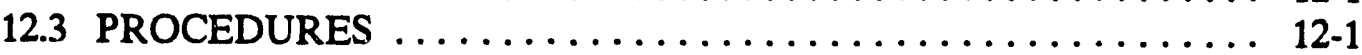

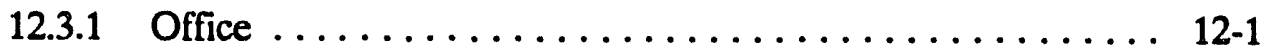

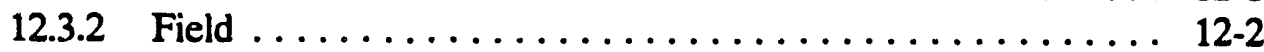

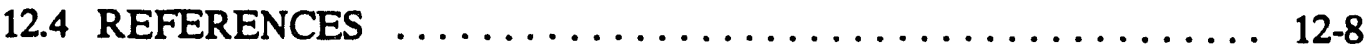

13. SAMPLING AND DRILLING SAFETY PROCEDURES ........ 13-1

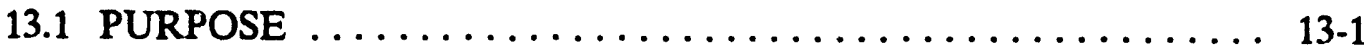

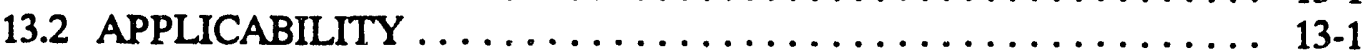

13.3 EQUIPMENT AND MATERIALS $\ldots \ldots \ldots \ldots \ldots \ldots \ldots \ldots \ldots$ 13-2

13.4 RESPONSIBILITIES ........................ 13-2

13.5 DEFINITIONS ........................... 13-4

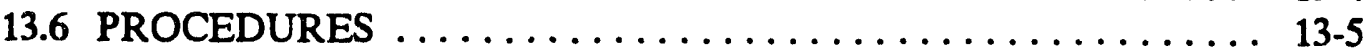

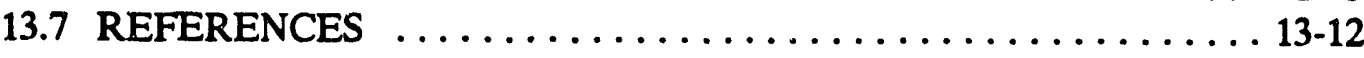


MARTIN MARIETTA

ENERGY SYSTEMS, INC.

Oak Ridge National Laboratory
Pollutant Assessments Group

Health and Safety

Procedures Manual
Front Matter

Date 4/92

Page $x$ of xxii

SUBJECT: CONTENTS

14. PHOTOIONIZATION DETECTOR (PID) $\ldots \ldots \ldots \ldots \ldots \ldots \ldots \ldots$ 14-1

14.1 PURPOSE ......................

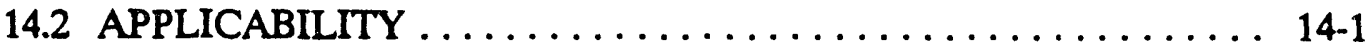

14.2.1 Specification Data ....................... 14-2

14.2.2 Control and Indicators . . . . . . . . . . . . . . . 14-3

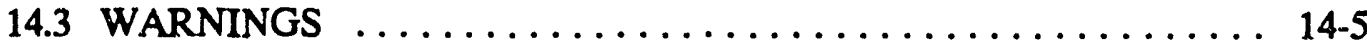

14.4 OPERATING PROCEDURES $\ldots \ldots \ldots \ldots \ldots \ldots \ldots \ldots \ldots$ 14-6

14.5 RECORDING THE PID OFFICE CHECK . . . . . . . . . . . 14-7

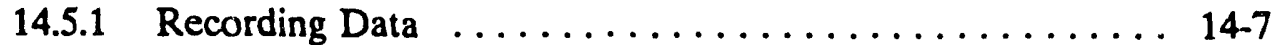

14.5.2 Postoperation .................... 14-7

14.6 BATTERY CHARGING $\ldots \ldots \ldots \ldots \ldots \ldots \ldots \ldots \ldots \ldots$ 14-9

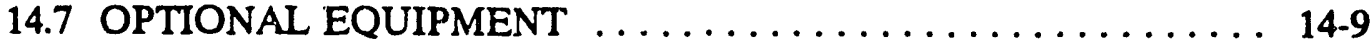

14.8 PID CALIBRATION $\ldots \ldots \ldots \ldots \ldots \ldots \ldots \ldots \ldots \ldots \ldots \ldots$ 14-11

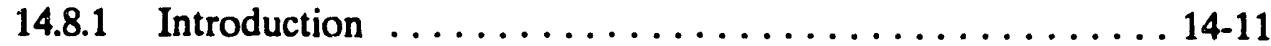

14.8.2 Calibration Gas Cylinder . . . . . . . . . . . . . 14-12

14.8.3 Probe Selection ... . . . . . . . . . . . . . . . . . . . 14-14

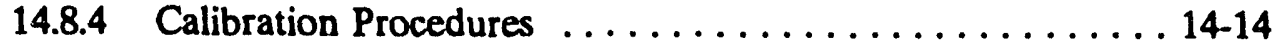

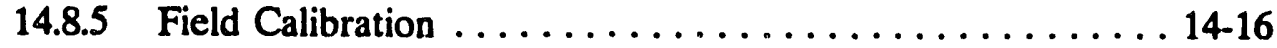

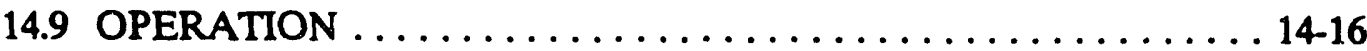

14.9.1 Recording Field Data .................. 14-16

14.9.2 Hazardous Waste Site Investigation . . . . . . . . . . . . 14-17

14.10 POSTOPERATION . . . . . . . . . . . . . . . . . . . . 14-18

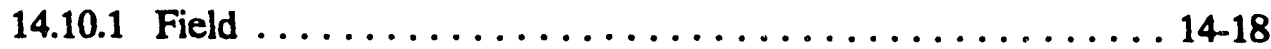

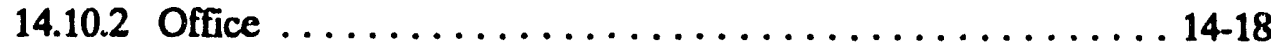

14.11 PID INSTRUMENT LIMITATIONS . . . . . . . . . . . . . . . 14-18

14.12 MAINTENANCE . . . . . . . . . . . . . . . . . . . . . . 14-19

14.12.1 Introduction ........................ 14-19

14.12.2 UV Lamp and Ion Chamber Cleaning . . . . . . . . . . 14-20

14.12.3 9.5- and 10.2-eV Lamps . . . . . . . . . . . . . 14-20

14.12.4 11.7-eV Lamp . . . . . . . . . . . . . . . . . . . . . . 14-20

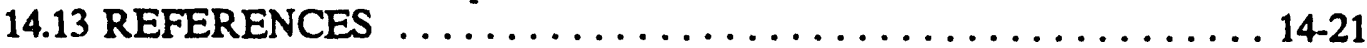

15. EXOTOX MODEL 50 COMBUSTIBLE GAS INDICATOR (CGI) . . . 15-1

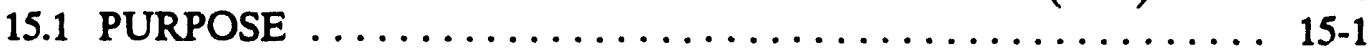

15.2 APPLICABILITY $\ldots \ldots \ldots \ldots \ldots \ldots \ldots \ldots \ldots \ldots \ldots \ldots \ldots \ldots$ 15-1

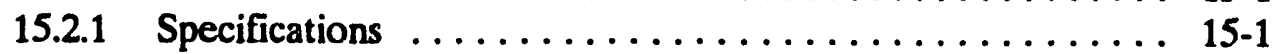

15.2.2 Normal Operation . . . . . . . . . . . . . . . . . 15-1

15.2.3 Mode Selection (Normal Operating Modes) ... . . . . . . 15-2

15.2.3.1 Channel LEDs . . . . . . . . . . . . . . . . . . 15-3

15.2.3.2 Oxygen real-time display mode ........... 15-3

15.2.3.3 Carbon monoxide real-time display mode ...... 15-3

15.2.3.4 Carbon monoxide TWA display mode $\ldots \ldots \ldots$ 15-3 
MARTIN MARIETTA ENERGY SYSTEMS, INC. Oak Ridge National Laboratury
Pollutant Assessments Group

Health and Safety

Procedures Manual
Front Matter

Date 4/92

Page xi of xxii

\section{SUBJECT: CONTENTS}

15.2.3.5 Carbon monoxide STEL display . . . . . . . 15-3

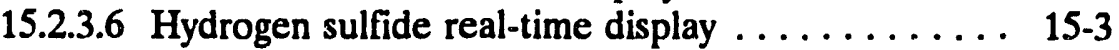

15.2.3.7 Hydrogen sulfide TWA display mode . . . . . . . 15-4

15.2.3.8 Hydrogen sulfide STEL display $\ldots \ldots \ldots \ldots \ldots$ 15-4

15.2.3.9 Explosive gas display mode $\ldots \ldots \ldots \ldots \ldots \ldots \ldots$ 15-4

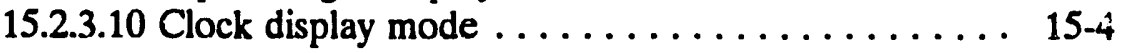

15.2.3.11 LCD backlight $\ldots \ldots \ldots \ldots \ldots \ldots \ldots \ldots \ldots \ldots$ 15-4

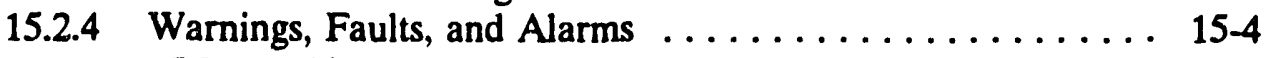

15.2.4.1 Alarm cancel .................. 15-5

15.2.4.2 Subsequent alarms ............... 15-5

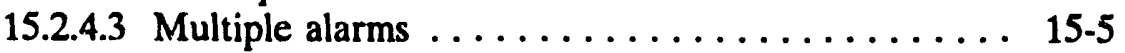

15.2.4.4 Alarm modes . . . . . . . . . . . . . 15-6

15.2.4.5 Battery exhaustion alarm ............. 15-7

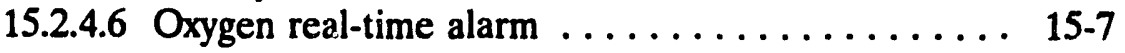

15.2.4.7 Hydrogen sulfide real-time alarm . . . . . . 15-7

15.2.4.8 Carbon monoxide real-time alarm . . . . . . . 15-7

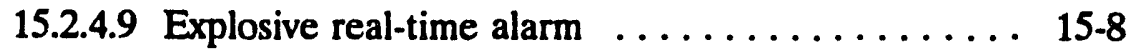

15.2.4.10 Hydrogen sulfide STEL alarm . . . . . . . . 15-8

15.2.4.11 Carbon monoxide STEL alarm . . . . . . . . 15-8

15.2.4.12 Hydrogen sulfide TWA alarm . . . . . . . . 15-8

15.2.4.13 Carbon monoxide TWA alarm ........... 15-9

15.2.5 Warnings ....................... 15-9

15.2.5.1 Fault indications . . . . . . . . . . . 15-10

15.2 .6 Standby Mode . . . . . . . . . . . . . . . . . . 15-11

15.2.7 Data Recording ..................... 15-11

15.2.8 Acoustic Earphone .................... 15-11

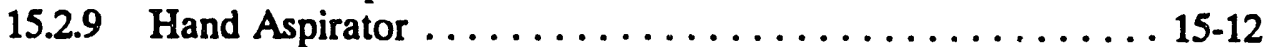

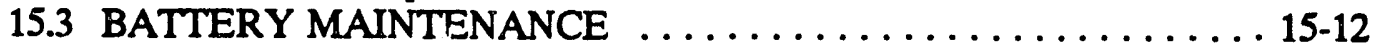

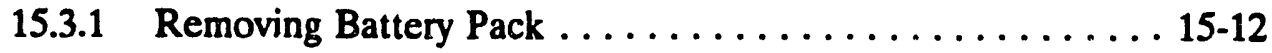

15.3.2 Battery Pack Contacts . . . . . . . . . . . . . . . 15-13

15.3.3 Charging the Battery . . . . . . . . . . . . . . 15-13

15.3.4 Battery Replacement ................... 15-14

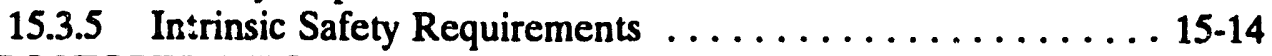

15.4 POSTOPERATION . . . . . . . . . . . . . . . . . . 15-14

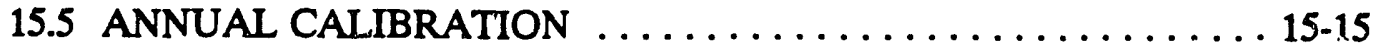

15.5.1 Performance Check .................. 15-15

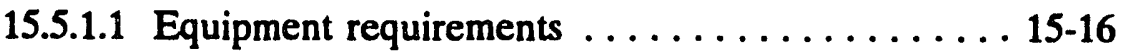

15.5.1.2 Functional check . . . . . . . . . . . 15-16

15.5.1.3 Gas calibration check ............ 15-17

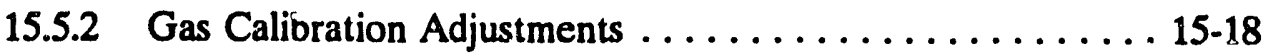

15.5.2.1 Oxygen calibration . . . . . . . . . . . . 15-20

15.5.2.2 Carbon monoxide calibration .......... 15-20 
MARTIN MARIETTA ENERGY SYSTEMS. INC.

Oak Ridge National Laboratory
Pollutant Assessments Group

Health and Safety

Procedures Manual
Front Matter

Date 4/92

Page xii of xxii

\section{SUBJECT: CONTENTS}

15.5.2.3 Hydrogen sulfide calibration $\ldots \ldots \ldots \ldots \ldots \ldots$ 15-20

15.5.2.4 Explosive test gas calibration (methane) . . . . . 15-21

15.5.2.5 Recording CGI office calibration .......... 15-21

15.6 REFERENCES

$15-25$

16. GASTECH MODEL GX-86 COMBUSTIBLE GAS INDICATOR (CGI) 16-1

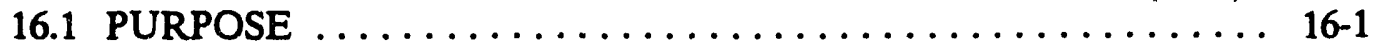

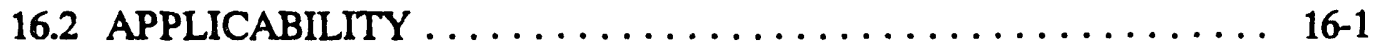

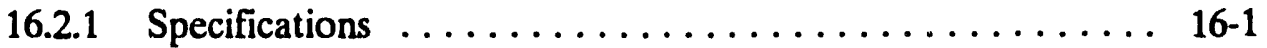

16.3 INSTRUMENT DESCRIPTION $\ldots \ldots \ldots \ldots \ldots \ldots \ldots \ldots \ldots 16-2$

16.3.1 Detection ....................... 16-2

16.3.2 Controls and Indicators . . . . . . . . . . . . 16-2

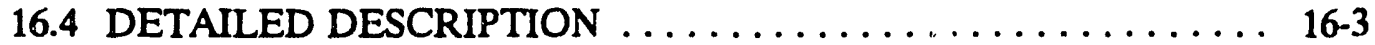

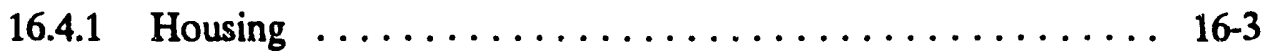

16.4.2 Combustible Gas Detector ................ 16-3

16.4.3 Carbon Monoxide and Hydrogen Sulfide Detectors . . . . . 16-3

16.4.4 Oxygen Detector . . . . . . . . . . . . . . . . . 16-4

16.4.5 Display ......................... 16-4

16.4.6 Controls and Indicators $\ldots \ldots \ldots \ldots \ldots \ldots \ldots \ldots \ldots \ldots \ldots$

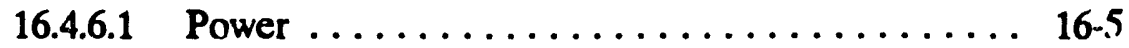

16.4.6.2 Voltage display $\ldots \ldots \ldots \ldots \ldots \ldots \ldots \ldots$ 16-5

16.4.6.3 Automatic zero adjustment ........... 16-8

16.4.6.4 Updated exposure rate .............. 16-8

16.4.6.5 Highest gas concentration ........... 16-8

16.4.6.6 Alarm lights $\ldots \ldots \ldots \ldots \ldots \ldots \ldots \ldots \ldots 16.8$

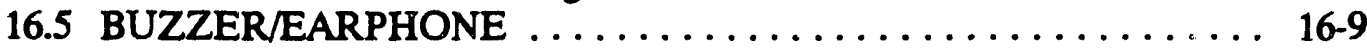

16.6 BATTERIES . . . . . . . . . . . . . . . . . . . . . . 16-9

16.7 CIRCUIT BOARDS $\ldots \ldots \ldots \ldots \ldots \ldots \ldots \ldots \ldots \ldots \ldots \ldots$ 16-9

16.8 PREPARATION $\ldots \ldots \ldots \ldots \ldots \ldots \ldots \ldots \ldots \ldots \ldots \ldots \ldots \ldots$ 16-11

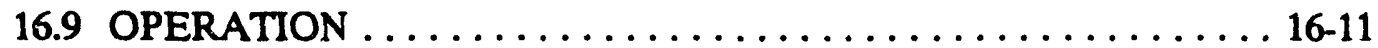

16.9.1 Initial Activation Procedures ............... 16-12

16.9.1.1 Data recording . . . . . . . . . . . . . 16-12

16.9.2 Span Adjustment . . . . . . . . . . . . . . . . . 16-12

16.9.3 Quick Field Check . . . . . . . . . . . . . . . . 16-12

16.10 DETECTION . . . . . . . . . . . . . . . . . . . . . 16-13

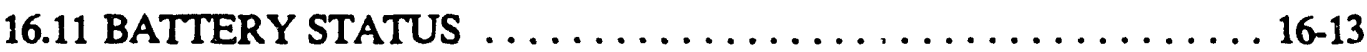

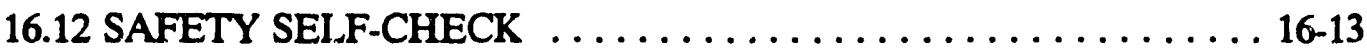

16.13 EMERGENCY OPERATION . . . . . . . . . . . . . 16-14

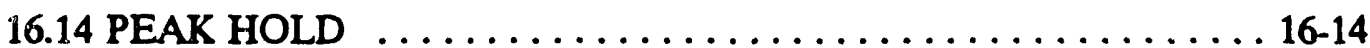

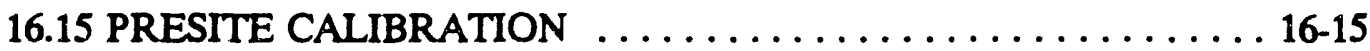

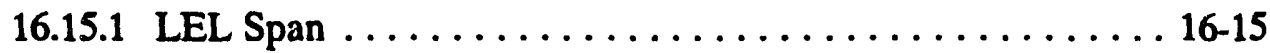

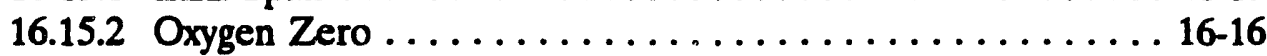


MARTIN MARIETTA ENERGY SYSTEMS, INC. Oak Ridge National Laboratory
Pollutant Assessments Group

Health and Safety

Procedures Manual
Front Matter

Date $4 / 92$

Page xiii of xoii

\section{SUBJECT: CONTENTS}

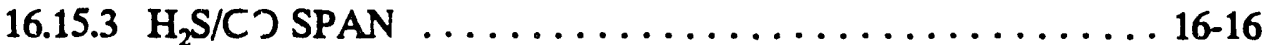

16.16 MAINTENANCE . . . . . . . . . . . . . . . . . . 16-16

16.16.1 Batteries ........................ 16-16

16.16.2 Combustibles Detector ................. 16-17

16.16.3 Oxygen Detector . . . . . . . . . . . . . . . 16-17

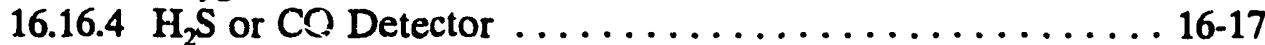

16.16.5 Detector Repair . . . . . . . . . . . . . . . . 16-18

16.16.5.1 Recording CGI office calibration .......... 16-18

16.16.6 Detector Removal/Replacement . . . . . . . . . . . . 16-19

16.16.7 CO Filter . . . . . . . . . . . . . . . . . . 16-19

16.17 OPTIONAL ACCESSORIES . . . . . . . . . . . . . . . . . 16-19

16.17.1 Extender Cable . . . . . . . . . . . . . . . . . 16-19

16.17.2 Sample Drawing Accessory . . . . . . . . . . . . 16-20

16.17.3 Confined Space Entry Kit . . . . . . . . . . . . 16-20

16.17.4 Lapel Buzzer . . . . . . . . . . . . . . . . 16-20

16.17.5 Earphones ...................... 16-20

16.17.6 Nickel-Cadmium Batteries . . . . . . . . . . . . . 16-21

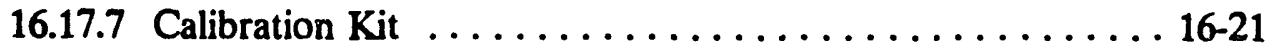

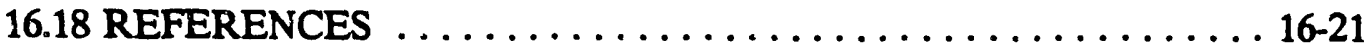

17. SENSIDYNE GAS DETECTOR SYSTEM $\ldots \ldots \ldots \ldots \ldots \ldots \ldots \ldots \ldots$. $\ldots \ldots-1$

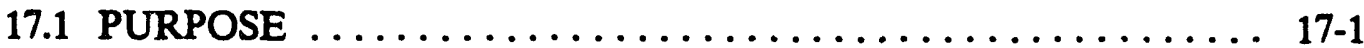

17.2 APPLICABILITY ........................ 17-1

17.2.1 Characteristics of Gastec Detector

System-Detector Tube ................. 17-2

17.2.2 Specifications-Sampling Pump .............. 17-2

17.3 ACCURACY OF GASTEC DETECTOR TUBE . . . . . . . . . 17-2

17.4 NORMAL OPERATION ..................... 17-5

17.4.1 Sampling and Measurement Procedure .......... 17-5

17.4.2 Correction for Temperature, Humidity, or Pressure . . . . . 17-5

17.5 DIFFERENT METHODS OF SAMPLING ... . . . . . . . . 17-6

17.5.1 Effect of Sampling Time and Related Data . . . . . . . 17-6

17.5.2 Tanks, Manholes, or Confined Spaces ... . . . . . . . 17-6

17.5.3 Leak-Check from Pipeline or Wellhead ... . . . . . . . . 17-7

17.5.4 Measurement and TLV of Liquid Mixture .......... 17-7

17.5.4.1 Elements evaporating from solvent ........ 17-7

17.5.4.2 Selecting measuring apparatus ......... 17-8

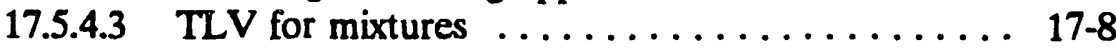

17.6 COMPRESSED AIR ACCESSORY $\ldots \ldots \ldots \ldots \ldots \ldots \ldots \ldots \ldots 1 . \ldots \ldots \ldots$

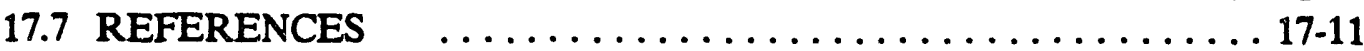


MARTIN MARIETTA

ENERGY SYSTEMS, INC.

Oak Ridge National Laboratory
Pollutant Assessments Group

Health and Safety

Procedures Manual
Front Matter

Date 4/92

Page xiv of xxii

\section{SUBJECT: CONTENTS}

18. QUEST ELECTRONICS MICRO-14 NOISE DOSIMETER . . . . . . . 18-1

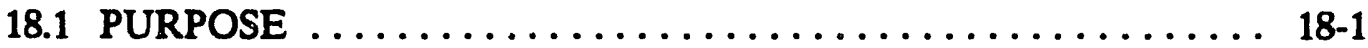

18.2 APPLICABILITY $\ldots \ldots \ldots \ldots \ldots \ldots \ldots \ldots \ldots \ldots \ldots \ldots \ldots \ldots \ldots$

18.3 SPECIFICATIONS $\ldots \ldots \ldots \ldots \ldots \ldots \ldots \ldots \ldots \ldots \ldots \ldots \ldots$ 18-1

18.4 INSTRUMENT DESCRIPTION $\ldots \ldots \ldots \ldots \ldots \ldots \ldots \ldots \ldots \ldots \ldots$ 18-2

18.5 DETECTION $\ldots \ldots \ldots \ldots \ldots \ldots \ldots \ldots \ldots \ldots \ldots \ldots \ldots \ldots \ldots$ 18-2

18.5.1 Microcomputer Modes ................ 18-3

18.5.2 Weighting Characteristics ................ 18-3

18.5.3 Microphone Characteristics ............... 18-3

18.5.4 Internal Electrical Noise $\ldots \ldots \ldots \ldots \ldots \ldots \ldots \ldots \ldots$ 18-3

18.6 CONTROLS AND INDICATORS $\ldots \ldots \ldots \ldots \ldots \ldots \ldots \ldots \ldots$ 18-3

18.7 READING DATA $\ldots \ldots \ldots \ldots \ldots \ldots \ldots \ldots \ldots \ldots \ldots \ldots \ldots$

18.7.1 Displayed Data ..................... 18-5

18.7.2 Data Recording . . . . . . . . . . . . . . . 18-5

18.8 OFFICE CALIBRATION $\ldots \ldots \ldots \ldots \ldots \ldots \ldots \ldots \ldots \ldots$ 18-5

18.9 FIELD CALIBRATION $\ldots \ldots \ldots \ldots \ldots \ldots \ldots \ldots \ldots \ldots \ldots \ldots$. . . . . . . .

18.10 OPERATING PROCEDURE $\ldots \ldots \ldots \ldots \ldots \ldots \ldots \ldots \ldots \ldots$ 18-8

18.10.1 Interpreting Results . . . . . . . . . . . . . . . . 18-9

18.10.1.1 Estimating TWA from AVG LEVEL . . . . . 18-9

18.10.1.2 Continuous or intermittent $\ldots \ldots \ldots \ldots \ldots \ldots$ 18-11

18.10.2 Considerations of Measurement and Accuracy . . . . . . 18-12

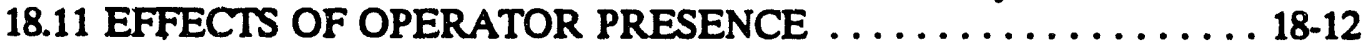

18.11.1 Use with Windscreen . . . . . . . . . . . . . . 18-13

18.11.2 Internal Electrical Noise . . . . . . . . . . . . . . . 18-13

18.11.3 Accuracy of Readings ................... 18-13

18.12 REFERENCES ........................... 18-14 
MARTIN MARIETTA

ENERGY SYSTEMS, INC.

Oak Ridge National Laboratory
Pollutant Assessments Group

Health and Safety

Procedures Manual
Front Matter

Date 4/92

Page xv of xxii

SUBJECT: LIST OF FIGURES

\section{LIST OF FIGURES}

Figure

Page

6.1 Example Plan Acceptance Form $\ldots \ldots \ldots \ldots \ldots \ldots \ldots, 6,2$

6.2 Site description $\ldots \ldots \ldots \ldots \ldots \ldots \ldots \ldots \ldots \ldots \ldots 6,4$

6.3 Emergency information $\ldots \ldots \ldots \ldots \ldots \ldots \ldots \ldots \ldots 6.6 \ldots$

6.4 Hazardous site training checklist $\ldots \ldots \ldots \ldots \ldots \ldots \ldots \ldots 6-7$

6.5 Daily instrument calibration check $\ldots \ldots \ldots \ldots \ldots \ldots \ldots 6.6 \ldots$

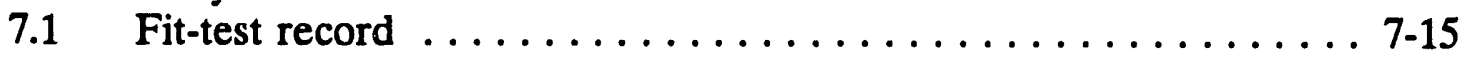

8.1 Accident Report Form .................... 8-4

8.2 Health and safety checklist $\ldots \ldots \ldots \ldots \ldots \ldots \ldots \ldots \ldots$ 8-6

8.3 Diagram of site work zones $\ldots \ldots \ldots \ldots \ldots \ldots \ldots \ldots \ldots$ 8-18

9.1 Minimum decontamination layout-Level $\mathrm{D}$ protection $\ldots \ldots \ldots .9-2$

10.1 Minimum decontamination layout-Level C protection ....... 10-6

10.2 Maximum decontamination layout--Level C protection . . . . . . 10-7

11.1 Maximum decontamination layout-Level B protection ........ 11-4

11.2 Minimum decontamination layout-Level B protection ........ 11-5

12.1 Minimum decontamination layout-Level A protection $\ldots \ldots \ldots$ 12-9

14.1 Air quality monitoring record $\ldots \ldots \ldots \ldots \ldots \ldots \ldots \ldots \ldots$ 14-8

14.2 ORNL service request $\ldots \ldots \ldots \ldots \ldots \ldots \ldots \ldots \ldots \ldots \ldots$ 14-10

14.3 Photoionization detector checklist ................ 14-13

15.1 Combustible gas indicator equipment checklist $\ldots \ldots \ldots \ldots \ldots$ 15-19

$18.1 \quad$ Noise Monitoring Form $\ldots \ldots \ldots \ldots \ldots \ldots \ldots \ldots \ldots \ldots \ldots$ 
MARTIN MARIETTA

ENERGY SYSTEMS, INC.

Oak Ridge National Laboratory
Pollutant Assessmenis Group

Health and Safety

Procedures Manual
Front Matter

Date 4/92

Page xvii of xxii

\section{SUBJECT: LIST OF TABLES}

\section{LIST OF TABLES}

Table

5.1 Hazardous material and environmental characteristic $\ldots \ldots \ldots \ldots \ldots .5-3$

5.2 Systemic poisons $\ldots \ldots \ldots \ldots \ldots \ldots \ldots \ldots \ldots \ldots \ldots \ldots \ldots$

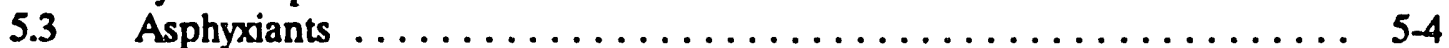

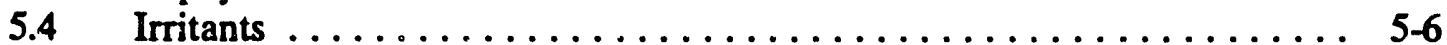

$5.5 \quad$ Allergic sensitizers $\ldots \ldots \ldots \ldots \ldots \ldots \ldots \ldots \ldots \ldots \ldots \ldots \ldots \ldots \ldots \ldots \ldots$

$5.6 \quad$ Carcinogens and teratogens $\ldots \ldots \ldots \ldots \ldots \ldots \ldots \ldots \ldots \ldots \ldots \ldots . \ldots \ldots$

5.7 Relative index of toxicity: Probable oral dose to humans ......... $5-10$

7.1 Effect of solvent vapor on respirator cartridge efficiency $\ldots \ldots \ldots \ldots$ 7-5

8.1 Safe working distances from electrical transmission lines for drilling $\ldots \ldots \ldots \ldots \ldots \ldots \ldots \ldots \ldots \ldots \ldots \ldots \ldots$ 8-14

8.2 Illumination recommendations $\ldots \ldots \ldots \ldots \ldots \ldots \ldots \ldots \ldots \ldots$ 8-48

9.1 Measures for Level D+ Decontamination ................. 9-5

10.1 Equipment needed for Level $C$ protection $\ldots \ldots \ldots \ldots \ldots \ldots \ldots$ 10-1

10.2 Equipment needed to perform minimum decontamination measures for Level $C \ldots \ldots \ldots \ldots \ldots \ldots \ldots \ldots$ 10-2

10.3 Equipment needed to perform maximum decontamination measures for Level $\mathrm{C} \ldots \ldots \ldots \ldots \ldots \ldots \ldots \ldots \ldots \ldots \ldots$ 10-4

10.4 Maximum measures for Level $C$ decontamination stations $\ldots \ldots \ldots \ldots$ 10-8

10.5 Minimum measures for Level $C$ protection $\ldots \ldots \ldots \ldots \ldots \ldots \ldots \ldots$ 10-11

11.1 Maximum equipment recommendations for Level B ............ 11-2

11.2 Minimum equipment recommendations for Level B ........... 11-3

11.3 Equipment needed to perform maximum decontamination measures for Level B . . . . . . . . . . . . . . . . . . . 11-7

11.4 Maximum measures for Level B protection and decontamination

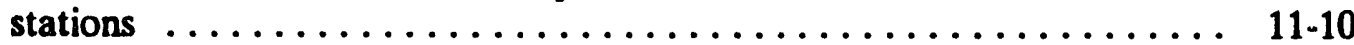

11.5 Equipment needed to perform minimum decontamination measures for Level B . . . . . . . . . . . . . . . . . . . . 11-13

11.6 Minimum measures for Level B decontamination stations . . . . . . . . . . 11-14

12.1 Equipment recommended for Level A protection . . . . . . . . . . . 12-3

12.2 Equipment needed to perform decontamination measures for Level A . . . . . . . . . . . . . . . . . . . . . . . . . . 12-4

12.3 Measures for Level A decontamination stations . . . . . . . . . . . 12-6

13.1 Safe working distance from power transmission lines $\ldots \ldots \ldots \ldots \ldots$ 13-11

14.1 Controls ............................. 14-3

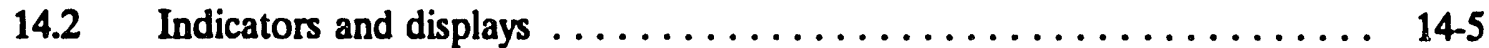

14.3 Typical applications of interchangeable probes .............. 14-15

14.4 Relative photoionization sensitivities for gases ............... 14-19 


\section{SUBJECT: LIST OF TABLES}

$15.1 \quad$ Alarm mode priority $\ldots \ldots \ldots \ldots \ldots \ldots \ldots \ldots \ldots \ldots \ldots \ldots, 15-6$

$15.2 \quad$ Negative reading warning point $\ldots \ldots \ldots \ldots \ldots \ldots \ldots \ldots \ldots \ldots, 15-10$

15.3 Display interpretation for the Exotox Model 50 CGI .......... 15-22

15.4 Alphanumeric display indications for the Exotox Model 50 CGI . ..... 15-23

15.5 Relative sensitivity to eiplosive and flammable gases

(for instruments calibrated with 20\% LEL of methane in air ....... 15-24

16.1 Indications-Model GX-86 . . . . . . . . . . . . .

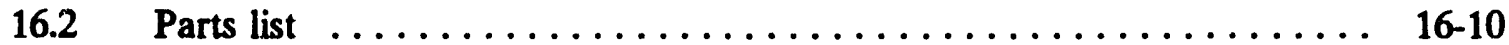

17.1 Purity of compressed air for breathing $\ldots \ldots \ldots \ldots \ldots \ldots \ldots \ldots, 17-10$

18.1 Corrections for computing 8-h TWA from short-term noise monitoring $\ldots \ldots \ldots \ldots \ldots \ldots \ldots \ldots \ldots \ldots \ldots \ldots \ldots, 1 ; s-9$

18.2 Threshold limit values for noise $\ldots \ldots \ldots \ldots \ldots \ldots \ldots \ldots \ldots \ldots$ 18-11 
MARTIN MARIETTA

ENERGY SYSTEMS, INC.

Oak Ridge National Laboratory
Front Matter

Date 4/92

Page xix of xxii

\section{SUBJECT: ACKNOWLEDGMENTS}

\section{ACKNOWLEDGMENTS}

This manual is a product of many staff members from within the ORNL/CAT project and from other groups. The major task of coordinating the overall completion of this manual was accomplished by J. E. Thate. Reviewers of various sections of the manual include: N. E. Korte, C. A. Little, D. R. Smuin, and A. K. Klitz. The author thanks these reviewers for their attention to detail and their enthusiasm for the task. The author also appreciates the manuscript preparation and revision by D. K. Barslund, T. L. Bradford, T. M. Williams, V. Johnson, and C. Griffith. Thanks go to Lydia S. Corrill and Victor Legg for editing, formatting, and coordination of publication.

This manual has not received formal review and approval by Martin Marietta Energy Systems, Inc. (MMES) and Oak Ridge National Laboratory (ORNL). The ORNL Chemical Assessments Team shall comply with MMES/ORNL policies and procedures. 


\section{ACRONYMS}

ACGIH

AIHA

ANSI

AVG

CERCLA

CFR

CGI

CPE

CPM

CPR

dB

dBA

DES

DOE

DOT

EKG

EPA

ER

FCC

FEV

FVC

HEPA

$\mathrm{H}_{2} \mathrm{~S}$

HR

$\mathrm{Hz}$

IDLH

IEC

IP

$\mathrm{LC}_{50}$

LD

$L_{\text {so }}$

LEL

LFL

LTE

MSDS

MSHA

NBR

NFPA
American Conference of Governmental Industrial Hygienists American Industrial Hygienist Association

American National Standards Institute average

Comprehensive Environmental Response, Compensation, and Liability Act of 1980

Code of Federal Regulations

combustible gas indicator

chlorinated polyethylene

Cr.emical Projects Manager

cardiopulmonary resuscitation

decibels

decibels on the A-weighted scale

diethyistilbestrol

Department of Energy

Department of Transportation

electrocardiogram

Environmental Protection Agency

exchange rate in decibels

Federal Communication Commission

forced expiratory volume in 1 Second

forced vital capacity

high-efficiency particulate air (filter)

hydrogen sulfide

heart rate

Hertz

immediately dangerous to life and health

International Electric Code

iobization potential

lethal concentration $50 \%$

lethal dose

lethal dose $50 \%$

lower explosive limit

lower flammable limit

long-term exposure

Material Safety Data Sheet

Mine Safety and Health Administration

nitrile butyl rubber

National Fire Protection Association 
MARTIN MARIETTA ENERGY SYSTEMS, INC. Oak Ridge National Laboratory
Pollutant Assessments Group

Health and Safety

Procedures Manual
Front Matter

Date 4/92

Page xxii of xxii

\section{SUBJECT: ACRONYMS}

\begin{tabular}{|c|c|}
\hline NIOSH & National Institute for Occupational Safety and Health \\
\hline NPL & National Priorities List \\
\hline NUREG & $\begin{array}{l}\text { U.S. Nuclear Regulatory Commission Document ORNL/CAT } \\
\text { Oak Ridge National Laboratory/Chemical Assessments Team }\end{array}$ \\
\hline OSHA & Occupational Safety and Health Administration \\
\hline OT & oral temperature \\
\hline PAG & Pollutant Assessment Group \\
\hline PEL & permissable exposure limit \\
\hline PID & photoionization detector \\
\hline PPE & personal protective equipment \\
\hline psi & pounds per square inch \\
\hline PSI & Preliminary Site Investigation \\
\hline PVA & polyvinyl alcohol \\
\hline PVC & polyvinyl chloride \\
\hline QA & quality assurance \\
\hline RASA/UMTRA & $\begin{array}{l}\text { Radiological Survey Activities/Uranium Mill Tailings Remedial } \\
\text { Action Project }\end{array}$ \\
\hline RASCA & Remedial Action Survey and Survey Activities \\
\hline RCRA & Resource Conservation and Recovery Act of 1976 \\
\hline RH & relative humidity \\
\hline $\mathbf{R I}$ & remedial investigation \\
\hline RM & readings per minute \\
\hline SARA & Superfund Amendments and Reauthorization Act of 1986 \\
\hline SB & sample bottle \\
\hline SCBA & self-contained breathing apparatus \\
\hline SL & surface location \\
\hline SOL & solubility in water $\mathrm{g} / 100 \mathrm{~g}$ water at $200 \mathrm{C}$ \\
\hline SPM & Site Project Manager \\
\hline SS & soil sample \\
\hline SSHO & Site Safety and Health Officer \\
\hline STEL & Short-term exposure limits \\
\hline TLV & threshold limit values \\
\hline TLV-C & threshold limit values-ceiling value \\
\hline TP & test pit \\
\hline TSD & transport, storage, and disposal \\
\hline TWA & time-weighted average \\
\hline UEL & upper explosive limit \\
\hline USCG & U.S. Coast Guard \\
\hline UV & ultraviolet \\
\hline WBGT & wet-bulb globe test \\
\hline WL & well location \\
\hline
\end{tabular}


MARTIN MARIETTA

ENERGY SYSTEMS, INC.

Oak Ridge National Laboratory
Pollutant Assessments Group

Health and Safety

Procedures Manual
Sect. 1 Rev. 2

Date 6/92

Page 1 of 1

\section{SUBJECT: INTRODUCTION}

\section{INTRODUCTION}

The Oak Ridge National Laboratory Chemical Assessments Team (ORNL/CAT) has developed this Health and Safety Procedures Manual for the guidance, instruction, and protection of ORNL/CAT personnel expected to be involved in hazardous waste site assessments and remedial actions. This manual addresses general and site-specific concerns for protecting personnel, the general public, and the environment from any possible hazardous exposures. The components of this manual include

- medical surveillance,

- guidance for determination and monitoring of hazards,

- personnel and training requirements,

- protective clothing and equipment requirements,

- procedures for controlling work functions,

- procedures for handling emergency response situations,

- decontamination procedures for personnel and equipment,

- associated legal requirements, and

- safe drilling practices.

This procedures manual ensures that the organizational, administrative, and technical activities of the ORNL/CAT personnel properly conform to operating procedures mandated by the U.S. Department of Energy (DOE); Martin Marietta Energy Systems, Inc. (Energy Systems); the U.S. Environmental Protection Agency (EPA); and other associated regulatory agencies. This manual also ensures that the techniques and procedures used by the ORNL/CAT and subcontractor personnel meet the requirements of applicable scientific and industrial standards.

\subsection{REAERENCES}

Code of Federal Regulations-29, Pt. 1900-1910, 7/87. 
MARTIN MARIETTA

ENERGY SYSTEMS, INC.

Oak Ridge National Laboratory
Pollutant Assessments Group

Health and Safety

Procedures Manual
Sect. 2 Rev. 2

Date 6/92

Page 1 of 1

SUBJECT: APPLICABILITY

\section{APPLICABILITY}

This procedures manual provides comprehensive guidelines for ORNL/CAT employees engaged in ha: ardous material management activities, including, but not limited to, initial site reconnaissance, planning, mobilization, field investigations, project operations, and demobilization. Additionally, if site-specific conditions dictate requirements beyond the scope of this manual, further mandates should be addressed.

Subcontractors engaged in hazardous materials management may be required to provide their employees with a health and safety plan covering any potential exposure to hazardous materials and shall complete all work in accordance with that plan. ORNL reserves the right to review, approve, and audit the subcontractor's health and safety plan at any time.

Grossly inadequate health and safety precautions on the part of the subcontractor, or belief that subcontractor personnel are or may be exposed to an immediate health hazard, can be cause for ORNL/CAT to suspend subcontractor site work and ask subcontractor personnel to evacuate the hazardous area.

The subcontractor may be required to provide its own safety equipment in accordance with the health and safety plan requirements and will comply with all regulations including Occupational Safety and Health Administration (OSHA) standards (29 CFR 1910 and 1926).

ORNL may require the subcontractor to follow an ORNL/CAT-prepared health and safety plan. Subcontractor personnel will be given a site-specific indoctrination, as necessary, prior to commencing work on a site. Similarly, ORNL/CAT may provide monitoring devices and other safety equipment. These arrangements will be completed, understood, and agreed upon in writing by all personnel prior to the commencement of site activities.

\section{REFERENCES}

Code of Federal Regulations-29, Pt. 1900-1910, 7/87. 
MARTIN MARIETTA

ENERGY SYSTEMS, INC.

Oak Ridge National Laboratory
Pollutant Assessments Group

Health and Safety

Procedures Manual
Sect. 3 Rev. 2

Date 6/92

Page 1 of 3

SUBJECT: ORGANIZATION

\section{ORGANIZATION}

\subsection{PURPOSE}

itiu purpose of this procedure is to outline relevant responsibilities of ORNL/CAT management.

\subsection{APPLICABILITY}

This directive applies to ORNL/CAT personnel performing duties for hazardous substance investigations.

\subsection{CHEMICAL PROJECTS MANAGER}

The chemical projects manager (CPM) directs the organizational, technical, and business requirements of hazardous waste site investigations and provides full-time professional support to the ORNL/CAT program. The CPM, assisted by the site project manager (SPM), will

1. Implement project activities according to federal, state, and local regulations.

2. Ensure that all necessary ORNL/CAT personnel, principal subcontractors, and local and pool subcontractors, including consultants, are provided for site investigations.

3. Provide technical assistance for health and safety, quality assurance, training, and community relations. 
MARTIN MARIETTA

ENERGY SYSTEMS, INC.

Oak Ridge National Laboratory
Pollutant Assessments Group

Health and Safety

Procedures Manual
Sect. 3 Rev. 2

Date 6/92

Page 2 of 3

SUBJECT: ORGANIZATION

\subsection{SITE PROJECT MANAGER}

The SPM shall plan and direct on-site investigations and operational efforts. The SPM, assisted by the site safety and health officer (SSHO), has primary responsibility to

1. Monitor task performance records of all personnel to ensure the required work practices are employed.

2. Ensure that personnel receive this plan, are aware of its provisions, are instructed in safe work practices, and are familiar with planned emergency procedures, and ensure that this is documented.

3. Confirm that all field personnel have verified documents on file supporting a minimum of the training or documented equivalent field experience and/or additional training as required by 29 CFR $1910.120(e)(1-9)$ and receive any additional training that is required specific with task requirements.

4. Ensure that personnel are aware of the potential hazards associated with site operations, affected media, routes of entry, signs and symptoms of exposure, and health effects.

5. Verify that appropriate personnel protective equipment and monitoring equipment are available and properly utilized by all on-site personnel.

6. Correct any work practices or conditions that may result in injury or hazardous exposure to site personnel, the general public, or the environment.

7. Prepare any accident/incident reports.

\subsection{SITE SAFETY AND HEALTH OFFICER (SSHO)}

The SSHO or designated representative shall be responsible for adherence to this Health and Safety Procedures Manual and shall assume the role of on-site safety coordinator in emergency response situations. The SSHO shall remain at the project site during activities. The SSHO reports directly to the CPM and and has the following responsibilities:

1. Implement project health and safety plans, perform site monitoring, report to the SPM for action if any deviations from the anticipated conditions exist, and authorize the cessation of work at site investigations if necessary.

2. Establish site emergency procedures.

3. Calibrate or ensure calibration of all monitoring equipment and record results.

4. Ensure that all monitoring equipment is operating correctly according to manufacturer's instructions, record field data, and if the equipment is not operating properly, provide maintenance.

5. Confirm that, prior to a hazardous waste site visit, site personnel have the proper medical surveillance program and health and safety training to qualify them to 
MARTIN MARIETTA

ENERGY SYSTEMS, INC.

Oak Ridge National Laboratory
Pollutant Assessments Group

Health and Safety

Procedures Manual
Sect. 3 Rev. 2

Date 6/92

Page 3 of 3

\section{SUBJECT: ORGANIZATION}

perform their assigned tasks. Identify all site personnel with special medical conditions (e.g., allergies).

6. Advise the SPM on the safest possible means of performing hazardous waste site investigations.

\subsection{PROJECT PERSONNEL} include

Responsibilities of project personnel involved in on-site investigations and operations

1. Take all reasonable precautions to prevent injury to themselves and fellow employees.

2. Perform only those tasks they can do safely, and immediately report any accidents and/or unsafe conditions to the SSHO.

3. Notify the SPM and SSHO of any special medical conditions (e.g., allergies) and ensure that all on-site personnel are aware of any such conditions.

4. Use their senses (all senses) to alert them to potentially harmful situations.

5. Practice good housekeeping. Keep everything orderly and out of potentially harmful situations.

6. Be familiar with the physical characteristics of investigations, including

- wind direction in relation to ground zero

- accessibility to associates, equipment, and vehicles

- hot-zones (areas of known or suspected contamination)

- site access

- nearest water sources.

\subsection{REFERENCES}

Code of Federal Regulations-29, Pt. 1900-1910, 7/87. 
SUBJECT: MEDICAL PROGRAM

\section{MEDICAL PROGRAM}

\subsection{PURPOSE}

A medical program has been established to safeguard the health of ORNL/CAT personnel. Two essential components of this program are routine health care and emergency medical care and treatment.

\subsubsection{Routine Health Care}

Routine health care will consist of

1. Preemployment medical examinations to establish state of health, baseline physiological data, and ability to wear personnel protection equipment, as required by 29 CFR 1910. The frequency and type of periodic examinations to be conducted thereafter shall be determined by the ORNL Health Division. Exit examinations will also be required.

2. Special medical examinations, care, and counseling in case of known or suspected exposures to toxic substances. Any special tests performed would depend on the chemical substance(s) to which the individual may have been exposed.

\subsubsection{Emergency Medical Care}

Site safety plans will address emergency medical care and treatment of remedial investigation personnel in the Emergency Response Contingency Guidelines section, including possible exposures to toxic substances and injuries resultirg from accidents or physical problems. The following items are to be included in emergency care provisions:

1. Conspicuous posting of name, address, and telephone number of the nearest medical treatment facility. A map and/or adequate directions for locating the facility should be readily available. 
MARTIN MARIETTA

ENERGY SYSTEMS, INC.

Oak Ridge National Laboratory
Pollutant Assessments Group

Health and Safety

Procedures Manual
Sect. 4 Rev. 2

Date 6/92

Page 2 of 9

SUBJECT: MEDICAL PROGRAM

2. Ability of the facility to provide care and treatment of personnel exposed or suspected of being exposed to toxic (or otherwise hazardous) substances should be ascertained. If the facility lacks toxicological capabilities, arrangements should be made for physician services, as necessary.

\subsection{APPLICABIITY}

ORNL has established a health monitoring program to identify, monitor, and prevent health risks for employees potentially exposed to hazardous materials. This program is mandatory for all employees who exceed 30 days of participation with hazardous substances exposure in excess of mandated permissible exposure limits or published exposure levels in a 12-month period, who are required to wear a respirator $\mathbf{3 0}$ days or more per year, or who are injured, become ill, or develop signs or symptoms as a result of possible overexposure involving hazardous substances.

The SSHO is responsible for ensuring compliance with this program and will schedule examinations for personnel involved and forward data and reports to the physician. The SSHO shall provide the ORNL HAZWOPER Program Coordinator witli the names of ORNL/CAT personnel on the medical surveillance program. Data and reports will be reviewed by the physician to determine the suitability of each individual for the performance of his assigned tasks.

\subsubsection{Health Records}

Personnel information is requested to enable the examining physician and safety personnel to provide an occupational health prograin directed toward protecting employees from potential hazards in their work environment and toward the reduction of these hazards. The records will document employee health status and any changes in health status through the years and will provide an account of any care or recommendations given.

This information will be used to determine unusual susceptibility to illness or injury from exposures in the work environment and to provide medical treatment and advice.

\section{Rules of Confidentiality}

The information contained in these files will be available only for review and use by examining and consulting physicians. 
MARTIN MARIETTA

ENERGY SYSTEMS, INC.

Oak Ridge National Laboratory
Pollutant Assessments Group

Health and Safery

Procedures Marual
Sect. 4 Rev. 2

Date 6/92

Page 3 of 9

SUBJECT: MEDICAL PROGRAM

The records will be securely maintained. Access will be limited to the medical director. A copy of these records should be securely maintained in the office of the physician.

Medical information about an applicant, employee, or annuitant may be disclosed only by a licensed physician; such disclosure is strictly controlled by legal guidelines.

\section{Program Participation}

Preemployment, periodic, and exit (at termination) medical examinations may be requested by the physician for employees involved in

1. Work around hazardous radiation sources.

2. Physical contact or potential physical contact with hazardous materials.

3. Strenuous work tasts, hazardous duty, or physical requirements more arduous than normal that may pose health complications to employees.

If the amount of hazardous material handling is extensive, the number of periodic examinations may need to be increased. Employees that remain eligible for tasks requiring air-purifying or supplied-air respirators will be required to participate every 12 months. The entire employee roster will be reviewed annually by a company physician to ensure the inclusion of all "at-risk" personnel.

\section{Disclosure Agreement}

A disclosure agreement generated by client physicians may be provided to personnel included in the health monitoring program. Signatures on the disclosure agreement are required for employment and to grant permission to disclose pertinent information to bealth care providers for respirator fit-testing, bioassay monitoring, and other specific client needs.

\subsection{Monitoring Program}

This monitoring program is designed for personnel whose work may involve exposure to hazardous materials above PELs for $\mathbf{3 0}$ days or more per year. The program will also satisfy the needs of laboratory analysts whose jobs require preplacement and/or periodic health assessment. Administrative, fiscal, secretarial, statistical, and other support personnel who are not required to work in areas in which the risk of exposure to toxic materials exists will generally not be included in an annual program but may be included after an accidental exposure. 
MARTIN MARIETTA

ENERGY SYSTEMS, INC.

Oak Ridge National Laboratory
Pollutant Assessments Group

Health and Safery

Procedures Manual
Sect. 4 Rev. 2

Date 6/52

Page 4 of 9

SUBJECT: MEDICAL PROGRAM include

Those employees that may have medical monitoring as a condition of employment

- chemists,

- microbiologists,

- toxicologists,

- physical scientists,

- technical personnel supporting those who may be exposer to hazardous materials of quantities equal to or exceeding OSHA-permissible exposure limit (PEL) mandates,

- personnel required to work at hazardous waste sites,

- personnel who collect various types of potentially hazardous samples (because of their exposure to levels of toxicants that are significantly in excess of ambient concentrations),

- maintenance personnel accidentally exposed to hazardous materials,

- personnel who perform custodial services in laboratories or areas where toxic materials are stored, and

- part-time and temporary employees whose jobs are similar to those of the specialists previously mentioned.

The decision about which employees are nominated will rest with the CPM, SPM, and the SSHO most familiar with the possible hazards involved and the ORNL HAZWOPER Program Coordinator and ORNL Health Division.

Occupational histories for all ORNL employees are developed and maintained in Oak Ridge, Tennessee.

Medical characteristics that may be of concern include

1. Vision. Visual acuity of less than 20/40 (Snellen) in one eye and 20/20 in the other, with or without corrective lenses; binocular vision; vision sufficient to read printed material the size of typewritten characters; depth perception, field of vision: and the ability to distinguish the basic colors of red, black, and yellow. Deviation from these requirements must be approved by an ORNL physician.

2. Hearing. Hearing loss to the point of being unable to hear warning signals should be considered.

3. Speech. Diseases or conditions resulting in miscommunication with site investigation personnel should be reviewed.

4. Olfactory sense. Abnormalities in the sense of smell that would conflict with the need to use odor thresholds to detect hazards should be a health concern. 


\section{SUBJECT: MEDICAL PROGRAM}

5. Respiratory system. Any chronic disease or condition affecting the respiratory system that would adversely affect the performance of duties as perceived by an ORNL physician.

6. Cardiovascular system. Organic heart disease (compensated or not) hypertension with repeated readings that exceed 150 systolic and 90 diastolic should be addressed by an ORNL physician.

An ORNL physician will also review results of employee physicals, if necessary, to determine how the following and other conditions should be considered:

- gastrointestinal system

- endocrine system

- genitourinary disorders

- extremities and spine

- nervous system

\section{Examinations}

The rate and content of monitoring examinations will be determined by an evaluation of the occupational risk (i.e., the probability of adverse effects of exposure). A baseline exam with periodic reexaminations are expected to suffice for most participants.

Participants are advised that this program of medical monitoring is not a direct substitute for "general checkups" or other periodic examinations designed to monitor or promote general health.

\section{Program Costs}

Medical monitoring costs for ORNL work-related conditions is covered by ORNL.

\section{Eramination Content}

ORNL conducts physical examinations of all employees at the time of hiring, periodically during employment, and at termination of employment.

\subsubsection{Medical history}

A medical and occupational history form will be completed by each individual preceding the physical examination. This allows health personnel to review occupational 
MARTIN MARIETTA

ENERGY SYSTEMS, INC.

Oak Ridge National Laboratory
Pollutant Assessments Group

Health and Safety

Procedures Manual
Sect. 4 Rev. 2

Date 6/92

Page 6 of 9

\section{SUBJECT: MEDICAL PROGRAM}

medical information and aids the examining physician in determining the appropriate scope of examination. When completed, the form will be turned over to the physician or physician's designee.

Medical histories are developed and maintained in Oak Ridge, Tennessee, for all ORNL employees.

A confidential health questionnaire will be submitted by subcontractors to an ORNL physician, if requested, regarding specific information concerning employee health.

Completed questionnaires will be delivered in person or mailed directly to ORNL Health Division.

\subsection{Privacy statement}

Each participant will be required to notify ORNL Health Division if any health concerns associated with work tasks arise. This information will be made part of the employee's medical records. Employee's written requests for the release of information will also be made a part of the permanent record.

\section{Diagnostic tests}

Each individual may receive a basic panel of blood and urine counts and chemistries to evaluate heavy-metal accumulation and blood-forming, kidney, liver, and endocrine/metabolic functions if requested by the Health Division. The following tests may be considered for routine monitoring by the physician.

\section{Blood tests}

1. White blood cell count and differential cell count

2. Hemoglobin and hematocrit

3. Total bilirubin

4. Serum glutamic-oxalacetic transaminase

5. Lactic dehydrogenase

6. Alkaline phosphatase

7. Uric acid

8. Creatinine

9. Urea nitrogen

10. Cholesterol

11. Glucose 
MARTIN MARIETTA

ENERGY SYSTEMS, INC.

Oak Ridge National Laboratory
Pollutant Assessments Group

Health and Safety

Procedures Manual
Sect. 4 Rev. 2

Date 6/92

Page 7 of 9

\section{SUBJECT: MEDICAL PROGRAM}

Urinalysis

1. Color and character

2. Specific gravity

3. $\mathrm{pH}$

4. Microscopic particles

5. Protein

6. Acetone

7. Glucose

$\underline{X \text {-rays }}$

A baseline chest X-ray should be at least a standard 14 in. $\times 17$ in. P-A (posterior-anterior) exposure. The film will be read or reviewed by a board-certified radiologist or other competent medical specialist. Subsequent periodic chest $\mathbf{X}$ rays will be performed when clinically indicated or at the discretion of the physician.

\section{Electrocardiogram}

An electrocardiogram (EKG) will be included in the baseline examination and at periodic intervals, as required by the physician.

\section{Pulmonary function}

Pulmonary function testing may be included in the baseline examination. The physician may include this test in the periodic examination, especially for employees with a respiratory system risk, such as those with significant need to don respiratory protection because of possible exposure to toxic dusts and irritants. The exam consists of simple tests of lung ventilation to measure forced expiratory volume in $1 \mathrm{~s}\left(\mathrm{FEV}_{1}\right)$ and forced vital capacity (FVC) and any other factors deemed necessary by the physician.

\section{Audiometry}

Audiometry is required as part of the baseline examination.

\section{Visual acuity}

Visual acuity may be tested as part of baseline and periodic examinations. 
MARTIN MARIETTA

ENERGY SYSTEMS, INC.

Oak Ridge National Laboratory
Pollutant Assessments Group

Health and Safety

Procedures Manual
Sect. 4 Rev. 2

Date $6 / 92$

Page 8 of 9

\section{SUBJECT: MEDICAL PROGRAM}

\section{Other special tests}

Workers who are significantly exposed to hazardous materials and/or working conditions may require special procedures in addition to the basic panel of tests. This need will be determined by the physician after reviewing medical history forms and materials of exposure and after consulting with supervisors. Provisions will be made for repeating tests when necessary.

\subsection{Reports and Actions}

In case of suspected exposure to hazardous materials, the examining physician will notify the employee about any findings that, in the physician's opinion, indicate adverse effects of occupational exposure or preexisting physical conditions.

\subsection{STRESS}

Under certain conditions, both physiological and psychological stress can contribute significantly to accidents or harm workers in other ways. To reduce the potential for abnormal physical stress or mental anxiety, the ORNL Health Division should be consulted.

\subsection{REFERENCES}

Code of Federal Regulations-29, Pt. 1900-1910, 1990.

Code of Federal Regulations-40, Pt. 150-189, 1990.

Condensed Chemical Dictionary-11th Ed., 1989. Revised by. N. Irving Sax, Richard J. Lewis, Sr.

DOE. 1985. Comprehensive Environmental Response, Compensation, and Liability Act Program. DOE Order 5480.14. U.S. Department of Energy, Washington, D.C.

Doull, J., Klaasen, C. D., and Amdur, M. O. 1986. Casarett and Doull's Toxicology, Macmillan, New York.

EPA. 1981. Health and safety requirements for employees engaged in field activities. Environmental Protection Agency Order 1440.1. U.S. Environmental Protection Agency, July 12, 1981.

Merck and Company, Inc. 1983. Merck Index-Tenth Ed., Rathway, N.J.

NIOSH. 1985. Occupational safety and health guidance manual for hazardous waste site activities. National Institute for Occupational Safety and Health, Occupational Safety and Health Administration, U.S. Coast Guard, and Environmental Protection Agency, DHHS (NIOSH) Publication 85-115, October 1985. 
MARTIN MARIETTA

ENERGY SYSTEMS, INC.

Oak Ridge National Laboratory
Pollutant Assessments Group

Health and Safety

Procedures Manual
Sect. 4 Rev. 2

Date $6 / 92$

Page 9 of 9

SUBJECT: MEDICAL PROGRAM

Occupation Health Guidelines for Chemical Hazards, January 1981, Part 1 of $3-$ PB83-154609.

Occupational Health Guidelines for Chemical Hazards, January, 1981, Part 2 of 3PB83-154609.

Occupational Health Guidelines for Chemical Hazards, January 1981, Part 3 of 3PB83-154609.

Registry of Toxic Effects of Chemical Substances, 1983-84 Cumulative Supplement to the 1981-82 Edition, NIOSH-Vol. 1 A-G.

Registry of Toxic Effects of Chemical Substances, 1983-84 Cumulative Supplement to the 1981-82 Edition, NIOSH-Vol. 2 H-Z.

Basic Science of Poisons, Macmillan Publishing Company, New York.

Threshold Limit Values and Biological Exposure Indices for 1986-1987, QV-600-A54 1986-87-3 445600669694.

Weast, R. C., and M. J. Astle. 1986. Handbook of Data on Organic Chemicals, Second Ed. 
MARTIN MARIETTA

ENERGY SYSTEMS, INC.

Oak Ridge National Laboratory
Pollutant Assessments Group

Health and Safety

Procedures Manual
Sect. 5 Rev. 2

Date 6/92

Page 1 of 18

\section{SUBJECT: TOXIC PROPERTIES OF HAZARDOUS MATERIALS}

\section{TOXIC PROPERTIES OF HAZARDOUS MATERIALS}

\subsection{PURPOSE}

Toxic materials cause local or systemic detrimental effects in an organism. Exposure to such materials does not always result in extreme health degradation or death, although that is often the most immediate concern. Types of toxic hazards can be categorized by the physiological effect they have on the organism, and a material may induce more than one physiological response. A brief description of the types of toxic hazards (applicable to hazardous waste site investigations and other considerations) of toxicity such as signs, symptoms, and target organs are detailed in this section.

\subsection{APPLICABIITTY}

All personnel who may be exposed to varied types and levels of toxic substances will be provided with information on the characteristics and possible health effects, routes of exposure, and signs and symptoms of exposure of these substances.

Prior to any site activities, the SSHO will compare all hazardous substances, suspected or known to be present at the site, to known health and safety hazards associated with potential routes of exposure. Personal hygiene, medical surveillance, decontamination, chemical-protective clothing and other personal protective equipment will be determined and selected after consulting with knowledgeable toxicological personnel and viable reference materials.

The site-specific safety plan will include a hazard evaluation describing the chemical characteristics for types of waste suspected and/or known to be present at investigation sites. 
MARTIN MARIETTA

ENERGY SYSTEMS, INC.

Oak Ridge National Laboratory
Pollutant Assessments Group

Health and Safety

Procedures Manual
Sect. 5 Rev. 2

Date $6 / 92$

Page 2 of 18

\section{SUBJECT: TOXIC PROPERTIES OF HAZARDOUS MATERIALS}

\section{Toxicological Determination}

OSHA's mandate as outlined in 29 CFR 1910.10 (Tables Z1, Z2, and Z3) will be consulted primarily for comparison of hazardous waste to mandated airborne exposure limits. The following sources will be consulted if determination of exposure limits cannot be made based on this mandate or if more-conservative safety measures are recommended therein:

- National Institute for Occupational Safety and Health, Recommendations for Occupational Health Standards, June 1990.

- American Conference of Governmental Industrial Hygienists, Threshold Limit Values and Biological Exposure Indices for 1990.

- Material Safety Data Sheets (MSDSs), developed by the manufacturer in regard to the substance of concern.

- Toxicological laboratory testing recognized and accepted by the majority of the health industry.

\subsection{Dependent Variables}

Variables for potential hazardous material exposure will be determined as adequately as possible by comparing individual and/or mixed concentrations to site-specific and environmental conditions such as the history of geologic, meteorologic, and hydrologic norms and unusual occurrences. Depositional variables dependent on amounts, time intervals, and containers. Hazardous material and environmental characteristics also to be researched may include but are not limited to those listed in Table 5.1.

\subsection{HAZARDOUS MATERIALS CHARACTERISTICS}

\subsubsection{Systemic Poisons}

Systemic poisons are chemical agents that act on specific target organs or organ systems (Table 5.2). A subgroup includes anesthetics and narcotics, which may not be toxic in the classical sense because they do not necessarily cause irreversible harm but can be extremely hazardous for response personnel because they can impair judgement and thought processes. Anesthetics and narcotics depress the central nervous system, resulting 
MARTIN MARIETTA

ENERGY SYSTEMS, INC.

Oak Ridge National Laboratory
Pollutant Assessments Group

Health and Safety

Procedures Manual
Sect. 5 Rev. 2

Date $6 / 92$

Page 3 of 18

\section{SUBJECT: TOXIC PROPERTIES OF HAZARDOUS MATERIALS}

Table 5.1. Hazardous material and environmental characteristics

\begin{tabular}{|c|c|}
\hline Parameter & Value $^{a}$ \\
\hline \multicolumn{2}{|c|}{ Characteristics of hazardous material } \\
\hline Deterioration extent & half-life in years \\
\hline Saturated vapor concentration & $\mathrm{g} / \mathrm{cm}^{3}$ \\
\hline Diffusion coefficient in air & $\mathrm{cm}^{2} / \mathrm{s}$ \\
\hline Heat of vaporization & $\mathrm{cal} / \mathrm{g}$ \\
\hline Thermal conductivity in air & $\mathrm{cal} / \mathrm{s}-\mathrm{cm}-\mathrm{K}$ \\
\hline Gas constant & cal/mole-K \\
\hline Diffusion coefficient of vapor through soil & $\mathrm{cm}^{2} / \mathrm{s}$ \\
\hline Vapor pressure & $\mathrm{mm} \mathrm{Hg}$ \\
\hline Diffusion coefficient of water vapor through air & $\mathrm{cm}^{2} / \mathrm{s}$ \\
\hline Initial concentration in soil (assumed) & $\mathrm{g} / \mathrm{cm}^{3}$ \\
\hline Absorption coefficients (assumed) & \% uptake \\
\hline Solubility & $\mathrm{mg} / \mathrm{L}$ \\
\hline Molecular weight & $\mathrm{g} /$ mole \\
\hline \multicolumn{2}{|c|}{ Environmental characteristics (assumed) } \\
\hline Humidity & $\%$ in $\mathbf{m m ~} \mathbf{H g}$ \\
\hline Stagnant air layer thickness & $\mathbf{c m}$ \\
\hline Temperature & ${ }^{\circ} \mathrm{F}$ \\
\hline Wind speed & $\mathrm{mph}$ \\
\hline Soil solid density & $\mathrm{g} / \mathrm{cm}^{3}$ \\
\hline Soil bulk density & $\mathrm{g} / \mathrm{cm}^{3}$ \\
\hline Volumetric soil water content & $\mathrm{cm}^{3} / \mathrm{cm}^{3}$ \\
\hline Soil air content & $\mathrm{cm}^{3} / \mathrm{cm}^{3}$ \\
\hline Depth of soil column & \\
\hline Water vapor flux per unit area & $\mathrm{g} / \mathrm{cm}^{2} /$ day \\
\hline
\end{tabular}

'Values for certain parameters may be found in various chemistry and physics handbooks or in the published literature.

in loss of sensation or stupor. If concentrations are great enough, coma and death can occur. Hazardous waste site personnel should notify the SSHO of any use of immunosuppressants, such as medications taken for the relief of influenza or any other medical complications, prior to or during site activities because use of such substances may simulate signs and symptoms of some toxic exposures. Personnel with any type of illness that would potentially increase health and/or safety risks to themselves or other personnel may be excluded from all site activities. 


\section{SUBJECT: TOXIC PROPERTIES OF HAZARDOUS MATERIALS}

Table 5.2 Systemic poisons

\begin{tabular}{ll} 
Anesthetics/Narcotics & Nervous System \\
Olefins & Methanol \\
Ethyl ether & Carbon disulfide \\
Isopropyl ether & Metals \\
Paraffinic hydrocarbons & Organometallics \\
Aliphatic ketones & \\
Aliphatic alcohols & Blood-Circulatory System \\
Esters & Ariline \\
& Toluidine \\
Liver Function & Nitrobenzene \\
Carbon tetrachloride & Benzene \\
Tetrachloroethane & Phenols \\
Kidneys Function & \\
Halogenated hydrocarbons & \\
\hline
\end{tabular}

\section{3 .2 Asphyxiants}

Asphyxiants (Table 5.3) are agents that deprive the tissues of oxygen-a condition called anoxia. This group is divided into simple and chemical asphyxiants. Air-purifying respirators cannot be used in these types of atmospheres; if ventilation equipment cannot be used, only self-contained or air-supplied breathing apparatuses will be donned.

Table 5.3. Asphyxiants

\begin{tabular}{ll}
\hline Simple Asphyxiants & Chemical Asphyxiants \\
Aliphatic hydrocarbons & Aniline \\
Helium & Methyl aniline \\
Nitrogen & Cyanogen \\
Hydrogen & Hydrogen cyanide \\
Nitrous oxide & Toluidine \\
Carbon dioxide & Carbon monoxide \\
Methane & \\
\hline
\end{tabular}


MARTIN MARIETTA

ENERGY SYSTEMS, INC.

Oak Ridge National Laboratory
Pollutant Assessments Group

Health and Safety

Procedures Manual
Sect. 5 Rev. 2

Date $6 / 92$

Page 5 of 18

\section{SUBJECT: TOXIC PROPERTIES OF HAZARDOUS MATERIALS}

\subsubsection{Simple asphyxiants}

The simple asphyxiants act by diluting or displacing atmospheric air, which lowers the concentration of oxygen in air. Breathing air with low oxygen concentration causes insufficient oxygen in blood and tissues. This can cause headache, unconsciousness, and eventually death. Inert gases, such as nitrogen used to purge monitoring wells, can be simple asphyxiants.

\subsubsection{Chemical asphyxiants}

One type of chemical asphyxiant prevents oxygen uptake in the blood. For example, carbon monoxide $(\mathrm{CO})$ interferes with the transport of oxygen to tissues by strongly binding with hemoglobin to form carboxyhemoglobin, which leaves inadequate hemoglobin available for oxygen transport.

A second type of chemical asphyxiation prohibits normal oxygen transfer either from the blood to the tissues or within the cell itself. Hydrogen cyanide is an example of this type.

An example of a common and extremely toxic compound that is both a chemical and simple asphyxiant is hydrogen sulfide $\left(\mathrm{H}_{2} \mathrm{~S}\right)$. The chemical action, actually that of a neurotoxic systemic poison, stops oxidation of the respiratory tissues, paralyzing the lungs. The result is that no air enters the lungs, which causes simple asphyxiation. Oxygen concentrations in the lungs drop, causing death.

\section{3 .3 Irritants}

Irritants are materials that cause inflammation of membranes. The mechanism of irritation is either corrosive action or drying action, which may affect the eyes, skin, respiratory membranes, or gastrointestinal tract. The irritant must come into direct contact with tissue to cause an inflammation reaction. Consequently, skin, eye, and respiratory irritants are the greatest concern for response personnel (Table 5.4). The SSHO will compare all potential occurrences for exposure to hazards on-site and select protective equipment and clothing that is most applicable to specific site conditions.

Skin exposure to irritating materials, in high enough concentrations, may result in contact dermatitis characterized by redness, itching, and drying of the skin. These dermatitis-causing materials are called primary irritants. Organic solvents are examples of primary irritants, which elicit a response in hours. Acids and alkalies are strong (or 
MARTIN MARIETTA

ENERGY SYSTEMS, INC.

Oak Ridge National Laboratory
Pollutant Assessments Group

Health and Safety

Procedures Manual
Sect. 5 Rev. 2

Date 6/92

Page 6 of 18

\section{SUBJECT: TOXIC PROPERTIES OF HAZARDOUSS MATERIALS}

absolute) irritants, which produce observable effects within minutes. Extremely corrosive agents can cause skin ulceration and destroy tissues.

Table 5.4. Irritants

\begin{tabular}{ll}
\hline Skin Irritants & Respiratory Irritants \\
Acids & Aldehydes \\
Alkalies & Ammonia \\
Solvents & Hydrogen chloride \\
Metallic salts & Ozone \\
Detergents & Nitrogen dioxide \\
\hline
\end{tabular}

If respiratory tissues are insulted by irritant gases or fumes, they constrict in a reflex fashion, accompanied by involuntary coughing. Tracheitis and bronchitis are inflammations of the major air passages. Examples of irritant gases are chlorine, ammonia, ozone, and sulfur dioxide. More insidious irritating agents can reach the terminal respiratory passages (alveoli) deep in the lungs and may result in pulmonary edema, pneumonia, and eventually death.

It is important to note that many particulates such as dusts, although not chemically active hazards, can be severely irritating.

\subsection{Allergic Sensitizers}

Sensitization to a chemical involves the immune mechanisms of the body. When a foreign substance, called an antigen, enters body tissue, it triggers production of antibodies, which react with the antigen to make it innocuous. On first exposure to a specific chemical, no antibodies are present in the body. After subsequent exposures the concentration of antibodies increases until a threshold is reached. At this point, the antibody level is high enough that, upon exposure to the chemical, the antigen-antibody reaction, also called an allergic reaction, is severe enough to manifest itself in one or more symptoms. The body has become "sensitized" to that chemical.

Skin and respiratory sensitizers may show the same symptoms as irritants (for example, dermatitis, bronchitis, and conjunctivitis), and can range from the discomfort of poison ivy to a fatal reaction from isocyanates (Table 5.5). Any history of allergies or suspected allergy symptoms must immediately be brought to the attention of the SSHO. 
MARTIN MARIETTA

ENERGY SYSTEMS, INC.

Oak Ridge National Laboratory
Pollutant Assessments Group

Health and Safety

Procedures Manual
Sect. 5 Rev. 2

Date 6/92

Page 7 of 18

SUBJECT: TOXIC PROPERTIES OF HAZARDOUS MATERIALS

Table 5.5. Allergic sensitizers

\begin{tabular}{lc}
\hline Skin Sensitizers & Respiratory Sensitizers \\
Poison ivy & Sulfur dioxide \\
Poison oak & Isocyanates \\
Epoxy monomers & \\
Nickel & \\
Formaldehyde & \\
Toluene diisocyanate & \\
\hline
\end{tabular}

\subsubsection{Carcinogens, Mutagens, and Teratogens}

Personnel directly involved with hazardous waste site sampling activities involving the possibility of exposure to hazardous levels of mutagenic, teratogenic, and carcinogenic substances will be excluded from any type of exposure to these substances (Table 5.6).

Table 5.6. Carcinogens and teratogens

\begin{tabular}{ll}
\hline Carcinogens & Teratogens \\
Halogenated hydrocarbons & $\begin{array}{c}\text { Diethylstibestrol (DES) } \\
\text { Polynuclear aromatics } \\
\text { Aromatic amines }\end{array}$ \\
\hline
\end{tabular}

Only Level A or B protection will be used in these types of conditions. If even a minimal chance for exposure to one or more of these hazards is suspected when performing operations in Level $\mathrm{D}$ or $\mathrm{C}$ protection, emergency escape masks will be readily available to all personnel for whom the potential for exposure exists.

An agent that can cause cancer in an organism is called a carcinogen. Mutagens change a gene in a sperm or egg cell of the parent; the parent is not affected, but offspring suffer the consequences. Teratogens also manifest changes in offspring, but these result from exposure of the embryo or fetus to the agent itself. Although some teratogens and carcinogens have been identified, it is not possible to accurately "pinpoint" mutagens because of the difficulty in observing mutagenic action in cells. 
MARTIN MARIETTA

ENERGY SYSTEMS, INC.

Oak Ridge National Laboratory
Pollutant Assessments Group

Health and Safety

Procedures Manual
Sect. 5 Rev. 2

Date 6/92

Page 8 of 18

SUBJECT: TOXIC PROPERTIES OF HAZARDOUS MATERIALS

\subsection{Radiation Standards}

The Procedures Manual for the ORNL Radiological Survey Activities Program provides formal procedures for conducting radiological surveys and includes program planning, personnel and equipment decontamination, equipment calibration operation, and quality assurance $(Q A)$ elements. These procedures manuals should be consulted when radiological exposure is suspected at a hazardous waste site.

\subsection{OTHER HAZARDOUS CONSIDERATIONS}

\subsubsection{Routes of Exposure}

The SSHO will monitor saie work practices to minimize and/or eliminate the potential for substances to enter the body. The three pathways for substance contact are exterior organs (i.e., skin), inhalation, and ingestion.

\subsubsection{Exterior organs}

The primary function of the skin is to act as a barrier against entry of foreign materials into the body. If this protective barrier is overcome, toxic chemicals enter. The barrier is greatly diminished by lacerations and abrasions. Also, many organic solvents greatly increase the permeability of the skin to materials that would otherwise not pass through it. Another vulnerability of the skin is that it provides a large surface area for contact with toxic agents. Personnel protective garments are explained in detail in Sects. 8,9 , and 10.

\subsubsection{Inhalation}

Inhalation is the most rapid route of exposure, immediately introducing toxic chemicals to respiratory tissues and the bloodstream. Once admitted to the blood through the lungs, these chemicals are quicilly transported throughout the body to contact all organs. A respiratory protection program is described in Sect. 6.

\subsubsection{Ingestion}

Health hazards to personnel from ingestion of materials are a lesser concern than skin and respiratory hazards. The number of substances that can be ingested are limited; however, the postinvestigation handling of improperly decontaminated or disposed of pens, 
MARTIN MARIETTA

ENERGY SYSTEMS, INC.

Oak Ridge National Laboratory
Pollutant Assessments Group

Health and Safery

Procedures Manual
Sect. 5 Rev. 2

Date 6/92

Page 9 of 18

SUBJECT: TOXIC PROPERTIES OF HAZARDOUS MATERIALS

clipboards, and other materials used at hazardous waste sites could still be a significant hazard. Also, ingestible materials get to the mouth only through hand-to-mouth contact. Even then, toxicity by mouth is of a lower order because of the acids, alkalies, and enzymes in the gastrointestinal tract. But these same conditions may enhance the toxic nature of the compound. Although ingestion of toxic chemicals is not a great on-site concern, studies have shown that gum and tobacco chewers can absorb significant amounts of hazardous substances during an 8-h day.

\subsection{Measurement of Toxicity}

\subsection{Dose response}

Potential toxic waste exposure will be determined prior to site entry, and adequate precautions must be taken. Generally speaking, a given amount of toxic agent will elicit a given type and intensity of response; this correlation is called a dose-response relationship and is the basis for measurement of the relative harmfulness of a chemical. Because humans cannot be used as test organisms, almost all toxicological data are derived from other mammalian species that are chosen for their ability to simulate human response; the results obtained are extrapolated to humans. For example, most skin tests are performed on rabbits because their skin response most closely resembles that of humans.

\subsection{Data analysis}

In much toxicological testing, the response measured is death. The test data are plotted on a dose-response curve. From this curve, the dose measured in milligrams (mg) of test agent per kilogram (kg) of body weight of the test organism is plotted and the percentage of test organisms killed can then be calculated. This dose is called the lethal dose (LD). Most often, experiments are designed to measure the dose that kills $50 \%$ of the test organisms, the lethal dose $50\left(\mathrm{LD}_{50}\right)$, which is a relative measurement of toxicity. If compound $A$ has an $\mathrm{LD}_{50}$ of $1000 \mathrm{mg} / \mathrm{kg}$ and compound $B$ has an $\mathrm{LD}_{50}$ of $500 \mathrm{mg} / \mathrm{kg}$, compound $B$ is more toxic than compound $A$ because a lower dose can produce the same effect at that dose. A value similar to $L D_{s 0}$ that is used for inhalation exposures is the lethal concentration $50\left(\mathrm{LC}_{\mathrm{SO}_{0}}\right)$, which is measured as parts per million of toxic agent per exposure time $(\mathrm{ppm} / \mathrm{h})$. Table 5.7 illustrates the use of $\mathrm{LC}_{50}$ values as a relative index of toxicity. 
MARTIN MARIETTA

ENERGY SYSTEMS, INC.

Oak Ridge National Laboratory
Pollutant Assessments Group

Health and Safety

Procedures Manual
Sect. 5 Rev. 2

Date 6/92

Page 10 of 18

\section{SUBJECT: TOXIC PROPERTIES OF HAZARDOUS MATERIALS}

Table 5.7. Relative index of toxicity: Probable oral lethal dose to humans

Toxicity rating or class

Dose

$>15 \mathrm{~g} / \mathrm{kg}$
$5-15 \mathrm{~g} / \mathrm{kg}$
$0.5-5 \mathrm{~g} / \mathrm{kg}$
$50-500 \mathrm{mg} / \mathrm{kg}$
$5-50 \mathrm{mg} / \mathrm{kg}$

$>5 \mathrm{mg} / \mathrm{kg}$
For average adult

More than 1 quart

Between 1 pint and 1 quart

Between 1 ounce and 1 pint

Between 1 teaspoonful and 1 ounce

Between 7 drops and 1 teaspoon

A taste (less than 7 drops)

Source: Toxicology: The Basic Science of Poisons, 2nd ed., Casarret and Doull (eds.), 1975.

\subsubsection{Dose rate concerns}

Another important preliminary site investigation (PSI) health factor to consider when determining the toxicity of a material is the relationship between concentration and exposure time. An acute exposure refers to a large single dose received over a short period of time. A chronic exposure is received as several small doses over a longer period of time. The difference (in terms of deleterious effects) is that a small acute exposure (e.g., of radiation) may result in no measurable effect on an organism, whereas a chronic exposure consisting of numerous small exposures may produce an additive effect. On the other hand, a large single dose in a short period of time might be much more hazardous than the same dose administered over a longer time.

\subsection{Practical considerations}

The most immediate concern for site investigation personnel is protecting the health of site workers and the public.

The characteristics of chemical compounds and hazard evaluation, as detailed on a site-specific health and safety plan, will dictate how the public is protected (e.g., PSI notification of local emergency response personnel and warning or evacuation of an area), how site personnel are protected (types of respiratory and protective gear employed), and what monitoring is required (continuous or intermittent). 
MARTIN MARIETTA

ENERGY SYSTEMS, INC.

Oak Ridge National Laboratory
Pollutant Assessments Group

Health and Safety

Procedures Manual
Sect. 5 Rev. 2

Date 6/92

Page 11 of 18

SUBJECT: TOXIC PROPERTIES OF HAZARDOUS MATERIALS

\subsection{CALCULATION OF EXPOSURE LIMITS}

\subsubsection{ACGIH Threshold Limit Values}

Every year the American Conference of Governmental Industrial Hygienists (ACGIH) revises their publication Threshold Limit Values for Chemical Substances and Physical Agents in the Workroom Environment with Intended Changes.

The current booklet on threshold limit values (TLVs) contains time-weighted average concentrations (TWAs) for the 8-h workday or 40-h week and short-term exposure limits (STELs) for excursions above the TWA. Other TLVs are found in the booklet concerning carcinogens, nuisance dusts, and other physical agents.

The TLVs are to be used by a trained individual to ensure proper interpretation and application of these values.

\subsubsection{Time-Weighted Averages}

The average chemical concentration most healthy workers can be exposed to during a 40-h week or 8-h day without adverse effects, chronic or acute, is designated as the TWA-TLV. The TLVs are given in parts per million (ppm) and/or milligrams per cubic meter $\left(\mathrm{mg} / \mathrm{m}^{3}\right)$. In general, parts per million is used for gases and vapors, and milligrams per cubic meter is used for particulates.

The following is a sample calculation of the TWA of worker exposure to a compound for comparison with the accepted TLV:

Given:

Concentration (ppm)

$$
\begin{aligned}
& C_{1}=15 \\
& C_{2}=21 \\
& C_{3}=18
\end{aligned}
$$

Exposure Time (h)

$$
\begin{aligned}
& t_{1}=2.5 \\
& t_{2}=2.5 \\
& t_{3}=2.5
\end{aligned}
$$

where

$$
i=1,2,3, \ldots, n
$$




$$
\begin{aligned}
& \text { TWA }=\sum \frac{\left[\left(C_{i}\right)\left(t_{i}\right)\right]}{t_{i}} \\
& \text { TWA }=\frac{\left[\left(C_{1}\right)\left(t_{1}\right)\right]+\left[\left(C_{2}\right)\left(t_{2}\right)\right]+\left[\left(C_{3}\right)\left(t_{3}\right)\right]+\ldots\left[\left(C_{n}\right)\left(t_{n}\right)\right]}{t_{1}+t_{2}+t_{3}+\ldots t_{n}} \\
& \text { TWA }=\frac{[(15)(2.5)]+[(21)(2.5)]+[(18)(2.5)]}{2.5+2.5+2.5} \\
& \text { TWA }=\frac{37.5+52.5+45}{7.5}
\end{aligned}
$$

TWA $=19.3$

This TWA should be compared with the TLV of the chemical to determine whether conditions are acceptable.

\subsection{TLVs Designated with "Skin" Notation}

Various substances, such as methanol, may be listed in the TLV booklet with the special designation "skin." This is to draw attention to another effect of the substance that may be as harmful as inhaling the substance. Direct skin contact with substances so designated should be avoided. Documentation of TLVs, published by the ACGIH, should be consulted to determine how and why the TLV for the skin was established.

\subsubsection{Excursions}

TWA-TLV may be exceeded for a short period of time if the listed TWA-TLV is not designated with "C." The $\mathrm{C}$ refers to the ceiling value of the TLV, otherwise referred to as the TLV-C. This TLV-C cannot be exceeded at any time or for any reason because of the inherent health risk. If no TLV-C exists, the TWA-TLV may be exceeded up to the 
MARTIN MARIETTA

ENERGY SYSTEMS, INC.

Oak Ridge National Laboratory
Pollutant Assessments Group

Health and Safety

Procedures Manual
Sect. 5 Rev. 2

Date 6/92

Page 13 of 18

\section{SUBJECT: TOXIC PROPERTIES OF HAZARDOUS MATERIALS}

time and concentration limit designated in the TLV booklet STEL. If no STEL is given for that compound, then any excursion attempt must be based on applicable industrial hygiene and toxicological data.

Any single excursion above the TWA-TLV cannot exceed $15 \mathrm{~min}$, and only four excursions are permitted each day. At least $1 \mathrm{~h}$ must elapse between each excursion. The excursion exposure time and concentration must be calculated into the TWA and must not exceed the TWA-TLV for the day.

Thus, any excursion, be it based on the STEL or other data, must be accompanied by an excursion of equal magnitude below the TWA-TLV. It must be remembered that any excursion limit given by the STEL is essentially the same as a TLV-C and should not be exceeded.

\subsubsection{Mixture TLV}

For situations in which more than one substance may be in the working environment (e.g., jet propellant JP-4), it is important to determine a TWA-mixture TWA-TLV. The first consideration is the overall effect of the mixture on the worker. If the substances have the same physiological or toxicological effects, then the TLVs must be considered additive. Such a TLV can be calculated as follows:

Concentration (ppm)

$C_{1}=400$
$C_{2}=150$
$C_{3}=100$
Exposure time (h)

$T_{1}=1000$

$T_{2}=200$

$T_{3}=200$

or

TWA $=\sum_{i=1}^{n} \frac{C_{i}}{T_{i}} \leq 1$

TWA $=\frac{C_{1}}{T_{1}}+\frac{C_{2}}{T_{2}}+\frac{C_{3}}{T_{3}} \cdots+\frac{C_{n}}{T_{n}}=1$ 


\section{SUBJECT: TOXIC PROPERTIES OF HAZARDOUS MATERIALS}

If the TWA of the mixture is greater than 1 , it exceeds the TLV for the mixture.

$$
n=\frac{400}{1000}+\frac{150}{200}+\frac{100}{200}=0.4+0.75+0.5=1.65
$$

If $\boldsymbol{n}$ is greater than or equal to 1 , then the TLV of the mixture has been exceeded. If the value is less than or equal to 1 , then the value is within the TWA-TLV for the mixture.

When effects of the individual substances are known to be other than additive, the TWA of each substance must be compared with its own TWA-TLV separately. An example might be a mixture of two gases, one having a narcotic effect and the other simply acting as an irritant.

To determine what kind of effect the TLV is based on, one must refer to the ACGIH Documentation of $T L V s$, which relates such information and cites references where more data may be found.

In many cases, an individual will be exposed to a variety of chemicals simultaneously. There are a variety of effects from this type of exposure. The simplest would be an additive effect, in which case the TLV calculations would be as follows:

$$
\begin{aligned}
& \text { Actual } \\
& \text { TWA-TLV TWA concentrations } \\
& \begin{array}{lrr}
\text { Benzene } & 10 \mathrm{ppm} & 5 \mathrm{ppm} \\
\text { Turpentine } & 100 \mathrm{ppm} & 25 \mathrm{ppm}
\end{array} \\
& \frac{5}{10}+\frac{25}{100}=0.5+0.25=0.75 \\
& 0.75<1
\end{aligned}
$$

Thus, the mixture concentration does not exceed the TWA-TLV of the mixture. 
MARTIN MARIETTA

ENERGY SYSTEMS, INC.

Oak Ridge National Laboratory
Pollutant Assessments Group

Health and Safery

Procedures Manual
Sect. 5 Rev. 2

Date $6 / 92$

Page 15 of 18

SUBJECT: TOXIC PROPERTIES OF HAZARDOUS MATERIALS

\subsubsection{Mineral Dust and Nuisance Dust TLV}

Dusts with less than $1 \%$ quartz content generally have a TLV of $10 \mathrm{mg} / \mathrm{m}^{3}$, which is equivalent to $30 \mathrm{ppm} / \mathrm{ft}^{3}$. Such dusts are considered a nuisance because they may be deposited in the ears, nasal passages, and eyes. They may block visibility. Such dusts may also be collected in the lungs, but any damage is usually reversible.

Dusts with greater than $1 \%$ quartz composition are considered mineral dusts and must be included in specific site safety assessment. Other mineral dusts, such as some types of sand used for grouting or abandoning monitoring wells, include silica, silicates, and coal dusts. Mineral dusts can cause irreversible lung damage.

\subsection{LEVEIS OF EXPOSURE}

\subsubsection{Protection Factors}

Protection factors are a measure of the overall effectiveness of a respirator. The protection factors of respiratory protection devices are a useful numerical tool to assist in the choice of a protective system. Filtering efficiency is a part of this factor and becomes a significant consideration for less efficient air-purifying respirators.

The protection factor of a given respirator times the permissable exposure limit (PEL), or TLV, for a given substance is the maximum allowable concentration for that substance for which the respirator may be used. Note that "quantitative" protection factors and "qualitative" protection factors differ. The correct protection factor must be used in determining the maximum allowable concentration (Sect. 6.7).

\subsubsection{Lower Flammable Limit}

In addition to toxic chemicals and irritants, it is necessary to consider levels of exposure for flammable substances and asphyxiants. Circumstances could exist in which the likelihood of either a chemical fire or high concentrations of gases is not detectable by monitoring. Thus, there will be a risk of creating toxic vapors or of causing asphyxiation because of the reduction of the oxygen content by displacement.

Contaminant concentrations in excess of these lower flammable limits (LFLs) are considered to be immediately dangerous to life or health (IDLH). At or above the LFL, the use of respirators is limited to those devices that provide the maximum protection [i.e., positive pressure self-contained breathing apparatus (SCBA) and the combination positive pressure supplied-air respirators with auxiliary positive pressure]. 


\section{SUBJECT: TOXIC PROPERTIES OF HAZARDOUS MATERIALS}

\subsection{IDLH}

The definition of IDLH provided in 30 CFR $11.3(t)$ is as follows:

"Immediately dangerous to life or health" means conditions that pose an immediate threat to life or health or conditions that pose an immediate threat of severe exposure to contaminants, such as radioactive materials, which are likely to have adverse cumulative or delayed effects on health.

The purpose of establishing an IDLH exposure concentration is to ensure that the worker can escape without injury or irreversible health effects from an IDLH concentration in the event of failure of the respiratory protective equipment. The IDLH is considered a maximum concentration above which only a highly reliable breathing apparatus providing maximum worker protection is permitted. Because IDLH values are conservatively set, an approved respirator may be used up to its maximum use concentration.

In establishing the IDLH concentration, the following factors are considered:

1. Escape without loss of life or irreversible health effects. Thirty minutes is considered the maximum permissible exposure time for escape.

2. Severe eye or respiratory irritation or other reactions that would prevent escape without injury.

IDLH should be determined from the following sources:

1. Specific IDLH provided in the literature, such as the AIHA (American Industrial Hygiene Association) Hygienic Guides.

2. Human exposure data.

3. Acute animal exposure data.

Where such data are lacking, acute toxicological data from analogous substances may be considered.

The following guidelines should be used to interpret toxicological data reported in the literature for animal species: 
MARTIN MARIETTA

ENERGY SYSTEMS, INC.

Oak Ridge National Laboratory
Pollutant Assessments Group

Health and Safety

Procedures Manual
Sect. 5 Rev. 2

Date $6 / 92$

Page 17 of 18

\section{SUBJECT: TOXIC PROPERTIES OF HAZARDOUS MATERIALS}

1. Where acute animal exposure data are available (30 min to 4-h exposure), the lowest exposure concentration causing death or irreversible health effects in any species is determined to be the IDLH concentration.

2. Chronic exposure data may have no relevance to acute effects and should be used in determining the IDLH concentration only after obtaining or making a competent toxicologic judgment.

3. Where there is no toxicologic evidence of an IDLH concentration, 500 times the permissible exposure limit shall determine the upper limit above which only a highly reliable breathing apparatus providing maximum worker protection is used.

\subsubsection{Escape}

ORNL will provide and require employees to carry an escape respirator where exposure may occur to extremely toxic airborne substances. This escape respirator provides a 5-min self-contained air supply. (An extremely toxic substance is defined as a gas or vapor having an $\mathrm{LC}_{50}$ of less than $10 \mathrm{ppm}$.)

\subsection{REFERENCES}

Code of Federal Regulations-29, Pt. 1900-1910, 1990.

Code of Federal Regulations-30, Pt. 1-199, 1988.

Code of Federal Regulations-40, Pt. 150-189, 1990.

Condensed Chemical Dictionary-11th Ed. 1987. Revised by N. Irving Sax, Richard J. Lewis, Sr.

DOE. 1985. Comprehensive Environmental Response, Compensation, and Liability Act Program. DOE Order 5480.14. U.S. Department of Energy, Washington, D.C.

Doull, J., Klaassen, C. D., and Amdur, M. O. 1986. Casarett and Doull's Toxicology: The

EPA. 1981. Health and safety requirements for employees engaged in field activities. Environmental Protection Agency Order 1440.1. U.S. Environmental Protection Agency, July 12, 1981.

Merck and Company, Inc. 1989. Merck Index-Eleventh Ed., Rathway, N.J.

NIOSH. 1985. Occupational safety and health guidance manual for hazardous waste site activities. National Institute for Occupational Safety and Health, Occupational Safety and Health Administration, U.S. Coast Guard, and Environmental Protection Agency, DHHS 90. (NIOSH) Publication 85-115, October 1985.

NIOSH. 1990. NIOSH pocket guide to chemical hazards. U.S. Department of Health and Human Services, DHHS (NIOSH) Publication 90-117, June 1990. Threshold Limit Values and Biological Exposure Indices for 1986-1987, QV-600-A54 1986-87 - 3 445600669694. 
MARTIN MARIETTA

ENERGY SYSTEMS, INC.

Pollutant Assessments Group

Sect. 5 Rev. 2

Health and Safety

Oak Ridge National Laboratory

Procedures Manual

SUBJECT: TOXIC PROPERTIES OF HAZARDOUS MATERLALS

Occupation Health Guidelines for Chemical Hazards, January 1981, Part 1 of 3PB83-154609.

Occupational Health Guidelines for Chemical Hazards, January, 1981, Part 2 of 3 PB83-154609.

Occupational Health Guidelines for Chemical Hazards, January 1981, Part 3 of $3-$ PB83-154609.

Registry of Toxic Effects of Chemical Substances, 1983-84 Cumulative Supplement to the 1981-82 Edition, NIOSH - Volume 1 A-G.

Registry of Toxic Effects of Chemical Substances, 1983-84 Cumulative Supplement to the 1981-82 Edition, NIOSH - Volume $2 \mathrm{H}-\mathrm{Z}$.

Weast, R. C., and Astle, M. J. 1986. Handbook of Data on Organic Chemicals-Second Ed. 
MARTIN MARIETTA

ENERGY SYSTEMS, INC.

Oak Ridge National Laboratory
Pollutant Assessments Group

Health and Safety

Procedures Manual
Sect. 6 Rev. 2

Date 6/92

Page 1 of 10

\section{SUBJECT: SITE-SPECIFIC HEALTH AND SAFETY WORK PLAN}

\section{SITESPECIFIC HEALTH AND SAFETY WORK PLAN}

\subsection{PURPOSE}

As detailed in OSHA regulations 29 CFR 1910.120 and 1926, a site-specific health and safety plan specifically designed for each hazardous waste site investigation must be prepared and approved before any site visit. This plan will address the site problems, known site hazards, personnel protective equipment needed, and procedures to be used.

\section{APPLICABIITY}

Known or suspected site hazards, health effects, protective measures, and monitoring methods involving personnel at an investigation site must be identified in the site health and safety work plan. Personnel training necessary to perform all tasks must be identified and checked against team personnel records. Records of training, site entry, sampling, incidents, and accidents must be kept current in field logbooks and documented for office archiving in regard to future determination of medical surveillance and associated site-specific requirements. Procedures to be used on the site, including operations, equipment use, medical surveillance, decontamination, sampling, and waste disposal, must be identified. All site personnel and subcontractors shall acknowledge that they have read and completely understood the site health and safety plan by completing the health and safety plan acceptance form (Fig. 6.1). 
MARTIN MARIETTA

ENERGY SYSTEMS, INC

Instructions: This form is to be completed by each person to work or visit on the subject project work site and returned to the site safety officer.

Client

Project

I have read, understood, and agree with the information set forth in this Health and Safety Plan (and attachments) and discussed in the Personnel Health and Safety briefing. I agree to perform my work in accordance with it.

Site safety and health hazards, routes of exposure, symptoms and signs of exposure, and health effects have been explained to me.

\section{Signed}

\section{Print Name}

Company Name

\section{Date}

Fig. 6.1. Example Plan Acceptance Form. 
MARTIN MARIETTA

ENERGY SYSTEMS, INC.

Oak Ridge National Laboratory
Pollutant Assessments Group

Health and Safety

Procedures Manual
Sect. 6 Rev. 2

Date 6/92

Page 3 of 10

\section{SUBJECT: SITE-SPECIFIC HEALTH AND SAFETY WORK PLAN}

\subsection{PROCEDURES}

Procedures, plans, and contacts for emergency responses shall be included and made readily available in a conspicuous place at the site. Important aspects considered include communication, available assistance, types of emergencies possible, and emergency response capabilities. Arrangements with local emerger. $y$ response and assistance agencies must be made in advance of site visits. Names, addresses, and telephone numbers of all local emergency facilities shall be included. A detailed map and/or concise written directions detailing emergency facility locations and transport routes shall also be part of the site safety plan and shall be conspicuously posted at the site and distributed to each member involved at specific hazardous waste investigations.

A 24-h telephone number shall be provided for accessing expert medical support.

The following list of items will be used as a guide to preparing site-specific health and safety plans.

1. Health and Safety Plan Acceptance Form (Fig. 6.1).

2. General information regarding facility health and safety hazards. Unusual site-specific features, control procedures, and hazard evaluation (Fig. 6.2).

3. Procedures and equipment needed to protect against hazards. (The list of protective equipment for on-site activities will include: activity, level, and protective equipment.)

4. Identification of personnel expected to be performing tasks at the site, their duties; training requirements, and associated medical surveillance.

5. Emergency contacts, phone numbers, location of closest available medical assistance, telephone, potable water supply, and toilet facilities (Fig. 6.3).

6. Required monitoring to accurately determine hazards, primarily air contaminants, radiation, confined spaces, ordnance, and specific wastes at the site.

7. Decontamination requirements.

8. Contaminated equipment and clothing disposal.

9. Large and small spill response plans.

10. Emergency Response Contingency Guidelines.

11. Site control procedures.

12. Confined-space procedures. 
Health hazards to personnel from ingestion of materials are a lesser concern than skin and respiratory hazards. The number of substances that can be ingested are limited;

however, the postinvestigation handling of improperly decontaminated or disposed of pens,

MARTIN MARIETTA

ENERGY SYSTEMS, INC.

Oak Ridge National Laboratory
Pollutant Assessments Group

Health and Safety

Procedures Manual
Sect. 6 Rev. 2

Date 6/92

Page 4 of 10

\section{SUBJECT: SITE-SPECIFIC HEALTH AND SAFETY WORK PLAN}

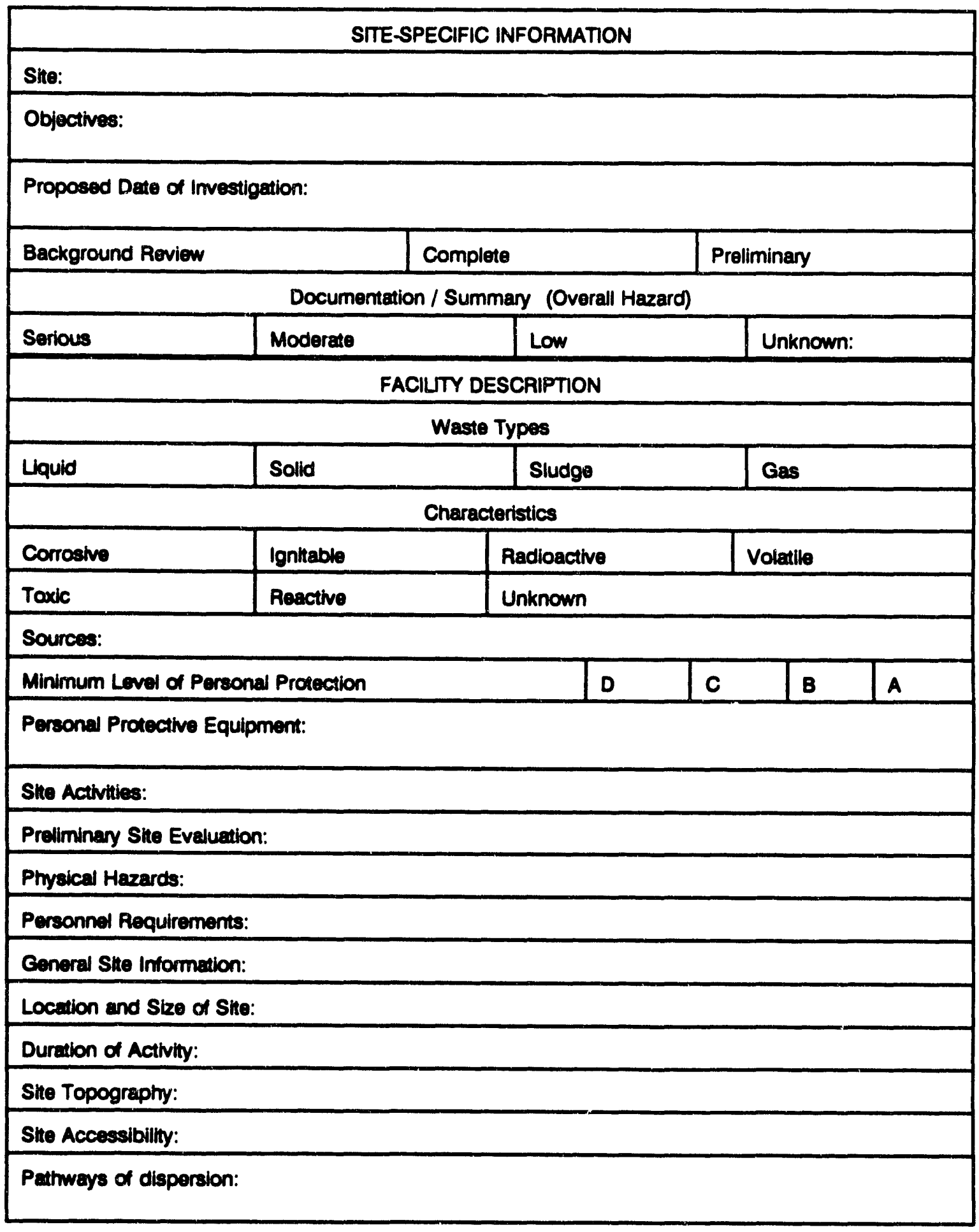

Fig. 6.2 Site description. 
MARTIN MARIETTA

ENERGY SYSTEMS, INC.

Oak Ridge National Laboratory
Pollutant Assessments Group

Health and Safery

Procedures Manual
Sect. 6 Rev. 2

Date 6/92

Page 5 of 10

\section{SUBJECT: SITE-SPECIFIC HEALTH AND SAFETY WORK PLAN}

Contact

\begin{tabular}{l} 
Contact \\
\hline Police \\
Fire \\
Ambulance \\
Hospital \\
Poison Control \\
ORNL Site Project Manager \\
ORNL Chemical Program Manager \\
ORNL Safety Coordinator
\end{tabular}

Person or

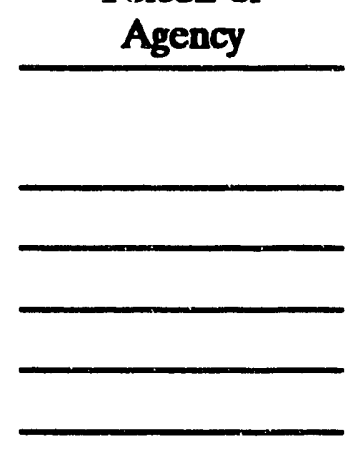

Work Telephone Numbers

\section{LOCATION OF SITE RESOURCES}

Water Supply :

Telephone :

Toilet Facilities :

\section{EMERGENCY ROUTE TO HOSPITAL}

Fig. 63. Emergency information. 
MARTIN MARIETTA

ENERGY SYSTEMS, INC.

Oak Ridge National Laboratory
Pollutant Assessments Group

Health and Safety

Procedures Manual
Sect. 6 Rev. 2

Date 6/92

Page 6 of 10

SUBJECT: SITE-SPECIFIC HEALTH AND SAFETY WORK PLAN

The ORNL SSHO will collect this information using data from the site assessment, with additional data acquired as needed. Although all of the above elements are considered, different tasks will require different levels of detail for the various elements. The site safety coordinator, CPM, SPM, quality assurance coordinator, and all other personnel assigned to the site will review the plan for quality and adequacy, then designate their modifications prior to final approval on the hazardous site training checklist (Fig. 6.4) at the PSI briefing. The ORNL HAZWOPER Program Coordinator and, if necessary, client IH and HP personnel shall review all Site Safety (and Health) Plans prior to commencement of site activities.

Data gathered during site assessments and investigations are used to modify the procedures, equipment, monitoring requirements, and precautions to be exercised during and following site visits. Work activities can reveal possible causes of an individual's exposure. These records and the knowledge of the hazardous materials at each site can be used to determine treatment methods when adverse health effects are observed after an exposure to potential toxic materials, after a site visit, or during the periodic health examination.

ORNL/CAT uses appropriate systems to track any data gathered. For example, normal site activities are performed in accordance with procedures delineated in this and other pertinent operating manuals. The use of these manuals ensures the rigorous and accountable generation of data relating to possible exposure.

\section{MONITORING}

\subsubsection{Monitoring Requirements}

Air monitoring will be conducted by IH and HP technicians for potential hazards at the site. The necessary monitoring equipment consists of a combustible gas indicator (CGI), photoionization detector (PID), and other equipment such as radiation meters and colorimetric tubes. All CGI and PID monitoring equipment shall be maintained following procedures outlined in this manual.

\subsection{Monitoring Schedule}

Monitoring will be performed upon entering potentially hazardous investigation sites and following the removal of well-head security caps on monitoring wells. PID, CGI, and/or radiation monitoring of ambient air, breathing zone, borehole space, and soil samples will be performed after each auger flight and/or sample device has been removed from a borehole until the site is determined to be void of hazardous working levels. Soil 
MARTIN MARIETTA

ENERGY SYSTEMS, INC.

Oak Ridge National Laboratory
Pollutant Assessments Group

Health and Safety

Procedures Manual
Sect. 6 Rev. 2

Date $6 / 92$

Page 7 of 10

\section{SUBJECT: SITE-SPECIFIC HEALTH AND SAFETY WORK PLAN}

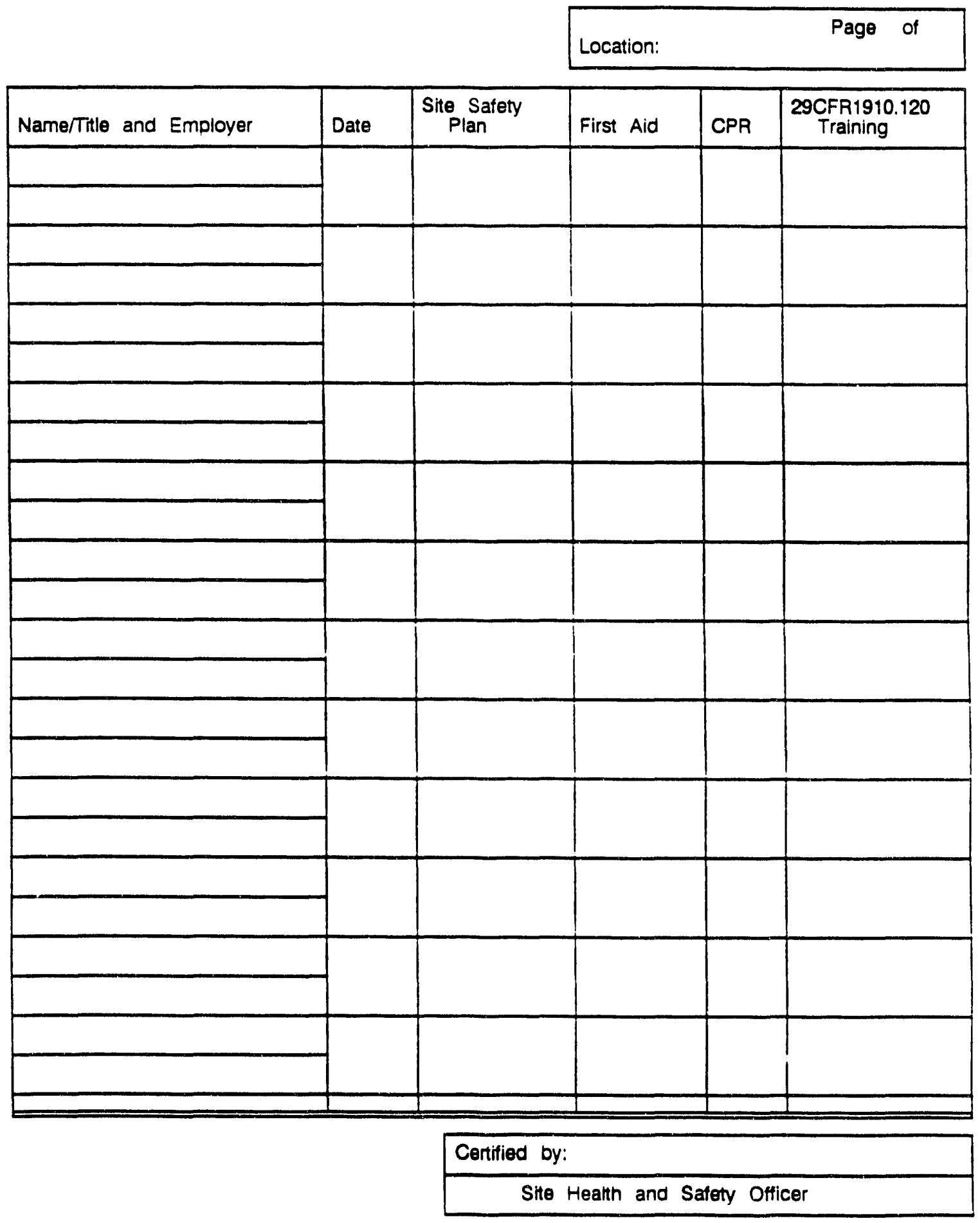

Fig 6.4. Havandous site training chocllist. 
MARTIN MARIETTA

ENERGY SYSTEMS, INC.

Oak Ridge National Laboratory
Pollutant Assessments Group

Health and Safety

Procedures Manual
Sect. 6 Rev. 2

Date 6/92

Page 8 of 10

\section{SUBJECT: SITE-SPECIFIC HEALTH AND SAFETY WORK PLAN}

samples suspected of containing hazardous concentrations will be monitored with the PID and radiation meters.

A monitoring schedule will be outlined in the site-specific health and safety plan. Additional monitoring equipment will be utilized when a perceived need exists.

If organic vapors, as measured on the PID, exceed $1 \mathrm{ppm}$ above background levels at the breathing zone for $30 \mathrm{~s}$ or more or the CGI alarm sounds, all personnel shall evacuate the work site. Following a reasonable period, organic vapors will again be monitored at the well and at the breathing zone. Monitoring will be performed again by using CGI and PID. If levels have subsided, drilling will resume; if not, the site will be evacuated and the work replanned.

\subsubsection{Instrument calibration}

All applicable gas, vapor, and noise measuring instruments shall be calibrated in accordance with Sect. 14 through 18. All other equipment will be calibrated as defined by site-specific health and safety plans and as required by the respective procedures manual. Readings shall be recorded in the designated instrument calibration logbooks.

Figure 6.5 illustrates the structure of the PID calibration logbook.

\subsubsection{Background readings}

Before any field activities commence, the background levels in an undisturbed location near the site will be monitored and recorded. To obtain accurate results, daily background readings shall take place upwind, away from areas of potential contamination.

\subsubsection{Recording environmental exposure levels}

All site readings shall be noted along with the date, time, background and elevated levels, meteorologic conditions, and location.

The SSHO will perform site-specific and/or radiation measurements at borehole and breathing levels following removal of each auger and/or sample flight when drilling, augering, or sampling. 
MARTIN MARIETTA

ENERGY SYSTEMS, INC.

Oak Ridge National Laboratory
Pollutant Assessments Group

Health and Safety

Procedures Manual
Sect. 6 Rev. 2

Date 6/92

Page 9 of 10

\section{SUBJECT: SITE-SPECIFIC HEALTH AND SAFETY WORK PLAN}

INSTRUMENT:

SERIAL NUMBER:

\begin{tabular}{lcccccc}
\hline $\begin{array}{l}\text { Calibration } \\
\text { gas (PPM) }\end{array}$ & $\begin{array}{c}\text { Span } \\
\text { setting }\end{array}$ & $\begin{array}{c}\text { Battery check } \\
\text { (good/bad) }\end{array}$ & $\begin{array}{c}\text { Calibrated } \\
\text { by }\end{array}$ & Time & Date & Remarks \\
\hline
\end{tabular}

Fig. 6.5. Daily instrument calibration check

\subsection{LEVEIS OF PROTECTION}

Designated levels of protection at hazardous waste sites shall be developed prior to conducting any work on-site, with potential for upgrades to properly adhere to any personnel protection requirements (Sect. 11).

\subsection{REFERENCES}

Code of Federal Regulations-29, Pt. 1900-1910, $7 / 87$.

Code of Federal Regulations-30, Pt. 1-199, 1986.

Code of Federal Regulations-40, Pt. 150-189, 7/86.

DOE. 1985. Comprehensive Environmental Response, Compensation, and Liability Act

Program. DOE Order 5480.14. U.S. Department of Energy, Washington, D.C.

EPA. 1981. Health and safety requirements for employees engaged in field activities.

Environmental Protection Agency Order 1440.1. U.S. Environmental Protection

Agency, July 12, 1981. 
NIOSH. 1985a. Occupational safety and health guidance manual for hazardous waste site activities. National Institute for Occupational Safety and Health, Occupational Safety and Health Administration, U.S. Coast Guard, and Environmental Protection Agency, DHHS (NIOSH) Publication 85-115, October 1985.

NIOSH. 1985b. NIOSH pocket guide to chemical hazards. U.S. Department of Health and Human Services, DHHS (NIOSH) Publication 85-11, September 1985.

Occupational Health Guidelines for Chemical Hazards, January 1981, Part 1 of 3PB83-154609.

Occupational Health Guidelines for Chemical Hazards, January 1981, Part 2 of 3PB83-154609.

Occupational Health Guidelines for Chemical Hazards, January 1981, Part 3 of 3PB83-154609. 


\section{SUBJECT: RESPIRATORY PROTECTION}

\section{RESPIRATORY PROTECTION}

\subsection{PURPOSE}

In accordance with 29 CFR 1910.134, ANSI Z88.2, and ANSI 88.6, employees will not be assigned to tasks requiring the use of respirators unless it has been determined that they are physically able to perform the work and use the equipment. At ORNL, this determination is made by means of an annual evaluation conducted by the ORNL Health Division. Information regarding the actions and responsibilities necessary for this medical evaluation can be obtained by contacting the Health Division.

The drilling and/or environmental sampling activities will be initiated at a level designated by the SSHO prior to any site work. If a flammable or oxygen-deficient atmosphere is measured on the CGI or if organic vapors measured on the PID exceed limits specified by the site health and safety plan, all personnel shall evacuate the work site by immediately moving upwind and, if possible, uphill from the area. Following a reasonable period, the ambient air will be monitored by the SSHO near the hazard generated at the breathing zone and at the borehole after taking all precautionary measures prior to site and off-site assessment of potential hazards.

\section{APPLICABILITY}

All personnel working in the field shall have completed a personnel protection and safety course, have been declared fit for duty, and, where respiratory protection is necessary, have been properly trained, fit-tested, and declared fit for respirator use following all guidelines listed in the ORNL Respiratory Protection Program Manual. 
MARTIN MARIETTA

ENERGY SYSTEMS, INC.

Oak Ridge National Laboratory
Pollutant Assessments Group

Health and Safety

Procedures Manual
Sect. 7 Rev. 2

Date 6/92

Page 2 of 24

\section{SUBJECT: RESPIRATORY PROTECTION}

\subsection{Supervisors of Respirator Users}

Supervisors of respirators users

1. are responsible for contacting IH prior to assigning work that may expose workers to hazardous substances or oxygen-deficient atmospheres,

2. are responsible for contacting IH for special equipment needs or unusually large orders of routinely used equipment,

3. shall be given training in the proper use of respirators and are responsible for surveillance of work areas to ensure that workers are using respiratory equipment properly, and

4. will ensure that HP is requested to tag used protective equipment by type of contaminant to which users were exposed (e.g., chemicais or asbestos).

\subsection{Division Safety Officers}

DSOs are responsible for keeping their line managers informed of the status of division personnel listed in the Respirator Master File.

\subsection{METHODS OF PROTECTION}

When it has been determined that the ambient atmosphere is hazardous, it becomes necessary to protect the individual by

1. avoiding and/or minimizing exposure;

2. applying engineering controls such as ventilation;

3. using a respirator to either filter the ambient air or supply clean air; and

4. documenting all personnel exposure incidents, respirator use, action levels, and total time of exposure for medical surveillance protocols.

\subsubsection{Legal Requirements}

The legal requirements for respiratory protection are summarized below.

1. 29 CFR 1910.134 and NUREG-0041 give legal requirements for the selection and use of respiratory equipment including airborne radioparticulates as promulgated by OSHA and based on American National Standards Institute (ANSI) Standard Z88.2, "American National Standards Practices for Respiratory Protection." Standard Z88.2 was originally a consensus standard but now has been cited as a federal regulation. 
MARTIN MARIETTA

ENERGY SYSTEMS, INC.

Oak Ridge National Laboratory
Pollutant Assessments Group

Health and Safety

Procedures Manual
Sect. 7 Rev. 2

Date 6/92

Page 3 of 24

\section{SUBJECT: RESPIRATORY PROTECTION}

2. 30 CFR 11 describes tests for permissibility of respiratory protective apparatus and update or delete approvals. 30 CFR Part 11 also cites ANSI Z88.2 as the basis for respiratory protection.

\subsubsection{Respirator Control Measures}

According to 29 CFR 1910.134 , employers will supply suitable respiratory protection equipment and establish a respiratory protection program that includes the following items:

1. Standard operating procedures for selection and use of respirators.

2. Proper selection of respirators on the basis of hazard.

3. Training of personnel in use and limitations.

4. Regular cleaning and maintenance.

5. Proper storage.

6. Routine monthly inspections and inspections before and after use.

7. Constant monitoring of work area for adverse conditions and worker stress.

8. Continual evaluation of respiratory compliance program.

9. Determination of medical fitness of potential user.

10. Use of only approved equipment and only after proper fit testing has been performed.

Testing schedules for respiratory equipment listed in 30 CFR 11 include:

1. Subpart H-Self-Contained Breathing Apparatus-Schedule 13.

2. Subpart I-Gas Masks-Schedule 14.

3. Subpart J-Supplied Air Respirators-Schedule 19.

4. Subpart K-Dust, Fume, and Mist Respirators-Schedule 23.

5. Subpart L-Chemical Cartridge Respirators-Schedule 23.

Document 30 CFR 11 also gives provisions for approval updates or deletions for respiratory equipment. Any equipment that is altered, hybridized, or changed in any unapproved way loses its approval. The approval number must be on the respirator or its container. 
MARTIN MARIETTA

ENERGY SYSTEMS, INC.

Oak Ridge National Laboratory
Pollutant Assessments Group

Health and Safety

Procedures Manual
Sect. 7 Rev. 2

Date 6/92

Page 4 of 24

\section{SUBJECT: RESPIRATORY PROTECTION}

\subsection{AIR-PURIFYING RESPIRATORS}

\subsubsection{Respirator Use Requirements}

The following basic facts are important for the use of the air-purifying respirator:

1. Air-purifying respirators employ filtering of air by the use of mechanical filters and/or sorbents.

2. Air-purifying respirators must not be used in atmospheres that are oxygen deficient (less than $19.5 \%$ or above $23.5 \% \mathrm{O}_{2}$ ).

3. Air-purifying respirators must not be used in atmospheres that are immediately dangerous to life and health.

4. The specific contaminant must be identified, both qualitatively and quantitatively.

5. Monitoring of the atmosphere must be performed while an air-purifying respirator is used.

6. A respirator fit-test must be performed and passed before the specific respirator can be used. The fit of the respirator changes with the growth of facial hair, weight loss/gain, dental work, etc.

7. Protection factors must be used to determine if a specific respirator can be used in a given atmosphere (Table 7.1).

\subsubsection{Types of Air-Purifying Respirators}

There are many different types of respirators for use in various circumstances.

1. Half-face respirators can be used in restricted conditions with inhalation hazard materials only.

2. Full-face respirators

a. cover entire face from under the chin to above the eyes, thus providing eye protection as well as respiratory protection

b. are usually made of either butyl, neoprene, or silicone rubber

3. Powered air-purifying respirators are positive-pressure respirators. 


\section{SUBJECT: RESPIRATORY PROTECTION}

Table 7.1. Effect of solvent vapor on respirator cartridge efficiency

\begin{tabular}{|c|c|}
\hline Solvent & $\begin{array}{c}\text { Time to reach } 1 \% \\
\text { breakthrough } \\
(\mathrm{min})\end{array}$ \\
\hline \multicolumn{2}{|l|}{ Aromatics } \\
\hline Toluene & 94 \\
\hline Ethyl benzene & 84 \\
\hline$m$-Xylene & 99 \\
\hline Cumene & 81 \\
\hline Mesitylene & 86 \\
\hline \multicolumn{2}{|l|}{ Alcohols } \\
\hline Methanol & 0.2 \\
\hline Ethanol & 28 \\
\hline Isopropanol & 54 \\
\hline Allyl alcohol & 166 \\
\hline n-Propanol & 70 \\
\hline SEC-Butanol & 96 \\
\hline Butanol & 115 \\
\hline 2-Methoxyethanol & 116 \\
\hline Isoamyl alcohol & 197 \\
\hline 4-Methyl-2-pentanol & 75 \\
\hline 2-Ethoxyethanol & 77 \\
\hline Amyl alcohol & 102 \\
\hline 2-Ethyl-1-butanol & 76.5 \\
\hline \multicolumn{2}{|l|}{ Monochlorides } \\
\hline Methyl chloride & 0.05 \\
\hline Vinyl chloride & 3.8 \\
\hline Ethyl chloride & 5.6 \\
\hline Allyl chloride & 31 \\
\hline 1-Chloropropane & 25 \\
\hline 1-Chlorobutane & 72 \\
\hline Chlorocyclopentane & 78 \\
\hline Chlorobenzene & 107 \\
\hline 1-Chlorohexane & 77 \\
\hline o-Chlorotoluene & 102 \\
\hline 1-Chloroheptane & 82 \\
\hline 3-Chloromethyl heptane & 63 \\
\hline
\end{tabular}


MARTIN MARIETTA

ENERGY SYSTEMS, INC.

Oak Ridge National Laboratory
Pollutant Assessments Group

Health and Safety

Procedures Manual
Sect. 7 Rev. 2

Date 6/92

Page 6 of 24

\section{SUBJECT: RESPIRATORY PROTECTION}

Table 7.1 (continued)

\begin{tabular}{|c|c|}
\hline Solvent & $\begin{array}{c}\text { Time to reach } 1 \% \\
\text { breakthrough } \\
(\mathrm{min})\end{array}$ \\
\hline \multicolumn{2}{|l|}{ Dichlorides } \\
\hline Dichloromethane & 10 \\
\hline Trans-1,2-dichloroethylene & 33 \\
\hline 1,1-Dichloroethane & 23 \\
\hline cis-1,2-Dichloroethylene & 30 \\
\hline 1,2-Dichloroethane & 54 \\
\hline 1,2-Dichloropropane & 65 \\
\hline 1,4-Dichlorobutane & 108 \\
\hline 0-Dichlorobenzene & 109 \\
\hline \multicolumn{2}{|l|}{ Trichlorides } \\
\hline Chloroform & 33 \\
\hline Methyl chloroform & 40 \\
\hline Trichloroethylene & 55 \\
\hline 1,1,2-Trichloroethane & 72 \\
\hline 1,2,3-Trichloropropane & 111 \\
\hline \multicolumn{2}{|l|}{ Tetra- and Pentachlorides } \\
\hline Carbon tetrachloride & 77 \\
\hline Perchloroethylene & 107 \\
\hline 1,1,2,2-Tetrachloroethane & 104 \\
\hline Pentachloroethane & 93 \\
\hline \multicolumn{2}{|l|}{ Acetates } \\
\hline Methyl acetate & 33 \\
\hline Vinyl acetate & 55 \\
\hline Ethyl acetate & 67 \\
\hline Isopropyl acetate & 65 \\
\hline Isopropenyl acetate & 83 \\
\hline Propyl acetate & 79 \\
\hline Allyl acetate & 76 \\
\hline SEC-Butyl acetate & 83 \\
\hline Butyl acetate & 77 \\
\hline Isopentyl acetate & 71 \\
\hline 2-Methoxyethyl acetate & 93 \\
\hline 1,3-Dimethylbutyl acetate & 61 \\
\hline 2-Methoxyethyl acetate & 93 \\
\hline
\end{tabular}


MARTIN MARIETTA

ENERGY SYSTEMS, INC.

Oak Ridge National Laboratory
Pollutant Assessments Group

Health and Safety

Procedures Manual
Sect. 7 Rev. 2

Date 6/92

Page 7 of 24

\section{SUBJECT: RESPIRATORY PROTECTION}

Table 7.1. (continued)

\begin{tabular}{|c|c|}
\hline Solvent & $\begin{array}{c}\text { Time to reach } 1 \% \\
\text { breakthrough } \\
(\mathrm{min})\end{array}$ \\
\hline $\begin{array}{l}\text { Amyl acetate } \\
\text { 2-Ethoxylethyl acetate } \\
\text { Hexyl acetate }\end{array}$ & $\begin{array}{l}73 \\
80 \\
67\end{array}$ \\
\hline $\begin{array}{l}\text { Ketones } \\
\text { Acetone } \\
\text { 2-Butanone } \\
\text { 2-Pentanone } \\
\text { 3-Pentanone } \\
\text { 4-Methyl-2-pentanone } \\
\text { Mesityl oxide } \\
\text { Cyclopentanone } \\
\text { 3-Heptanone } \\
\text { 2-Heptanone } \\
\text { Cyclohexanone } \\
\text { 5-Methyl-3-heptanone } \\
\text { 3-Methylcyclohexanone } \\
\text { Diisobutyl ketone } \\
\text { 4-Methylcyclohexanone }\end{array}$ & $\begin{array}{r}37 \\
82 \\
104 \\
94 \\
96 \\
122 \\
141 \\
91 \\
101 \\
126 \\
86 \\
101 \\
71 \\
111\end{array}$ \\
\hline $\begin{array}{l}\text { Alkanes } \\
\text { Pentane } \\
\text { Hexane } \\
\text { Methylcyclopentane } \\
\text { Cyclohexane } \\
\text { Cyclohexane } \\
\text { 2,2,4-Trimethylpentat : } \\
\text { Heptane } \\
\text { Methycyclohexane } \\
\text { 5-Ethylidene-2-norborn ne } \\
\text { Nonane } \\
\text { Decane }\end{array}$ & $\begin{array}{l}61 \\
52 \\
62 \\
69 \\
86 \\
68 \\
78 \\
69 \\
87 \\
76 \\
71\end{array}$ \\
\hline
\end{tabular}


MARTIN MARIETTA

ENERGY SYSTEMS, INC.

Oak Ridge National Laboratory
Pollutant Assessments Group

Health and Safety

Procedures Manual
Sect. 7 Rev. 2

Date 6/92

Page 8 of 24

\section{SUBJECT: RESPIRATORY PROTECTION}

Table 7.1. (continued)

\begin{tabular}{lc}
\hline \multicolumn{1}{c}{ Solvent } & $\begin{array}{c}\text { Time to reach 1\% } \\
\text { breakthrough } \\
\text { (min) }\end{array}$ \\
\hline Amines & \\
Methyl amine & 12 \\
Ethyl amine & 40 \\
Isopropyl amine & 66 \\
Propyl amine & 90 \\
Diethyl amine & 88 \\
Butyl amine & 110 \\
Triethyl amine & 81 \\
Dipropyl amine & 93 \\
Diisopropyl amine & 77 \\
Cyclohexyl amine & 112 \\
Dibutyl amine & 76 \\
& \\
Miscellaneous Materials & \\
Acrylonitrile & 49 \\
Pyridine & 119 \\
1-Nitropropane & 143 \\
Methyl iodide & 12 \\
Dibromomethane & 82 \\
1,2-Dibromoethane & 141 \\
Acetic anhyd:ide & 124 \\
Bromobenzene & 142 \\
\hline
\end{tabular}

\subsubsection{Donning of Respirators}

The respirator is placed over the face, and the straps are securely drawn. The bottom straps are secured first. The mask should not be so tight that it causes discomfort or headache. ANSI (1988) specifications should be consulted to make an adequate determination.

Once the respirator is secured, positive- and negative-pressure tests are conducted. (See Sect. 7.4.6.) 
MARTIN MARIETTA

ENERGY SYSTEMS, INC.

Oak Ridge National Laboratory
Pollutant Assessments Group

Health and Safety

Procedures Manual
Sect. 7 Rev. 2

Date $6 / 92$

Page 9 of 24

\section{SUBJECT: RESPIRATORY PROTECTION}

\subsubsection{Escape Mask Use}

Response personnel may have to carry escape masks when on sites presenting potential respiratory hazards. These masks are used when IDLH atmospheres are anticipated, breakthrough is noticed when using a respirator, or someone in the work party snows symptoms of respiratory distress, as dictated in ANSI (1988), Sect. 9.3. Only escape masks (not rescue or regular work masks) are to be used for escape.

Procedures for donning a typical escape mask are

1. Open case.

2. Pull out air capsule. (Mask should be packed so that it can be pulled forward out of case).

3. Unfold hood.

4. Pull start ring.

5. Remove and discard other respirator (if one is being worn).

6. Slip hood over head starting from back of head.

7. Pull drawstring tight and adjust elastic neck band.

\subsubsection{Respirator Fit-Testing}

ORNLCAT has committed itself to providing approved National Institute for Occupational Safety and Health/Mine Safety and Health Administration (NIOSH/MSHA) air-purifying respirators with full-face masks to those employees who may need to enter and work in an atmosphere that is known to contain adequate oxygen (above $19.5 \% \mathrm{O}_{2}$ ) and contaminants that have good warning properties and that is not immediately dangerous to life and health because of the presence of toxic contaminants. ORNL has identified several manufacturers (Wilson, Norton, MSA, Scott, etc.) who carry respirators that are suitable for use. Each company manufactures one or more full-face mask, air-purifying cartridge/canister respirator. Each make and model has a slightly different fit. Although each manufacturer designs facepieces to fit as broad a section of the working population as possible, no respirator marketed will fit everyone. Conditions that affect a good facepiece fit include: growth of beard, sideburns, a skull cap that projects under the facepiece, temple pieces on glasses, facial scars, facial injuries, and presence or absence of dentures. ORNL has, therefore, selected several manufacturers so that each employee can take advantage of the different fitting characteristics to find a respirator that fits properly. The opportunity to select from various manufacturers allows the wearer to choose a respirator that is reasonably comfortable while providing good protection.

OSHA regulations (29 CFR Part 1910.134) require that each person who wears a respirator shall have it properly fitted, test the facepiece for face seal, and wear it in a test 
MARTIN MARIETTA

ENERGY SYSTEMS, INC.

Oak Ridge National Laboratory
Pollutant Assessments Group

Health and Safety

Procedures Manual
Sect. 7 Rev. 2

Date $6 / 92$

Page 10 of 24

\section{SUBJECT: RESPIRATORY PROTECTION}

atmosphere. In compliance with this regulation, ORNL provides each respirator user with a fit-test to determine his/her ability to obtain a satisfactory fit with a "negative pressure" air-purifying respirator. The results of the fit-test will be used to select the specific type, make, and model of respirator for use by the wearer.

The following policies will also be adhered to in the fitting and use of the respirators:

1. To be allowed to use a respirator, an employee must have passed the fit-test.

2. If it is found that an employee cannot obtain a good respirator-to-face seal because of physical or medical characteristics, that employee will not use and/or enter an atmosphere that will require the use of a respirator.

3. Facial hair such as beards, sideburns, or certain moustaches that may interfere with the fit-test are not allowed.

4. Persons requiring corrective lenses shall be provided with specially mounted lenses inside the full-face mask. In circumstances in which ORNL IH approval has been obtained, contact lenses and/or glasses may be worn while using respirators.

5. Although fit-testing for positive-pressure self-contained breathing apparatus is not required as described in ANSI Z88.2 (draft revision 1978), a less-than-acceptable respirator-to-face seal will increase the use of air via leakage and, therefore, reduce effective breathing time. Such leaks may pose a hazard to the user if sufficient air is not available to reach an uncontaminated air supply.

6. A person may only use the specific make(s) and model(s) of air-purifying respirators for which he/she has obtained a satisfactory fit via the qualitative fit-testing procedures. Under no circumstances shall a person be allowed to use any make or model of respirator that has not been previously fit-tested or that has failed a fit-test.

In the commitment to comply with the fit-testing requirements, ORNL has selected qualitative rather than quantitative fit-testing procedures. This selection was made because the two-stage, cross-checking procedures described in the following will afford the necessary quality assurance that the user of an air-purifying, cartridge/canister respirator is properly fitted in a hazardous atmosphere. Passing a qualitative fit-test allows the respirator wearer to enter atmospheres up to the TLV or PEL times the protection factors.

Qualitative fit-test procedures involve two stages of testing. Stage 1 includes a simple respirator positive- and negative-pressure sealing check for facepiece fit. Stage II exposes the respirator wearer to a test atmosphere. This will include two separate atmosphere tests to double-check the adequate fit of the respirator. 
MARTIN MARIETTA

ENERGY SYSTEMS, INC.

Oak Ridge National Laboratory
Pollutant Assessments Group

Health and Safety

Procedures Manual
Sect. 7 Rev. 2

Date 6/92

Page 11 of 24

\section{SUBJECT: RESPIRATORY PROTECTION}

\subsubsection{Stage I Fit-Testing}

\subsubsection{Positive-pressure sealing test}

This test is performed after donning an air-purifying respirator that contains an exhalation and inhalation valve. It is conducted by closing off the exhalation valve and exhaling gently. The fit of a respirator equipped with a facepiece is considered to be satisfactory if a slight positive pressure can be built up inside the facepiece for a least $10 \mathrm{~s}$ without detecting any outward leakage of air between the sealing surface of the facepiece and the respirator wearer's face.

This test is made only as a gross determination of fit when the respirator is to be used in relatively hazardous atmospheres. Nonetheless, this test shall be employed just prior to entering any hazardous atmosphere.

\subsubsection{Negative-pressure sealing test}

The wearer can perform this test by himself in the field or office after donning the air-purifying respirator. The test is performed by closing off the inlet opening of the respirator cartridge(s) by covering it with the palm of the hand(s) so that it will not allow the passage of air, inhaling gently, and holding the breath for at least $10 \mathrm{~s}$. If the facepiece collapses slightly and no inward leakage of air into the facepiece is detected, it can be reasonably assumed that the fit of the respirator is satisfactory.

This test, like the positive-pressure sealing check, is to be used only as a gross determination of fit when the respirator is to be used in relatively hazardous atmospheres. (Both the positive- and negative-pressure sealing checks can be used on the SCBA air mask to determine the gross fit characteristics). This test shall be used just before entering any hazardous atmosphere.

During any fit-test, the respirator headstraps must be as comfortable as possible. Overtightening of the straps will sometimes reduce or increase facepiece leakage and may also prevent the wearer from tolerating the mask for a period of time.

\subsubsection{Stage II Fit-Testing}

A person wearing an air-purifying respirator will be exposed to two test agents: isoamyl acetate, an odorous vapor, and stannic chloride, an irritant smoke. An air-purifying respirator is used and equipped with an air-purifying cartridge that effectively 
MARTIN MARIETTA

ENERGY SYSTEMS, INC.

Oak Ridge National Laboratory
Pollutant Assessments Group

Health and Safety

Procedures Manual
Sect. 7 Rev. 2

Date $6 / 92$

Page 12 of 24

\section{SUBJECT: RESPIRATORY PROTECTION}

removes the test agents from respired air. If the respirator wearer is unable to detect penetration of the test agent into the respirator, he/she has achieved a satisfactory fit.

\subsubsection{Isoamyl acetate test}

Isoamyl acetate is a chemical that produces a pleasant banana-smelling organic vapor. It is an easily detectable odor. The isoamyl acetate fit-test will be conducted as per ANSI Z.88.2. This field test is performed by using a plastic garbage bag over a coat hanger as a test hood covering; this apparatus is suspended from the ceiling by a rope. Inside the plastic bag, a piece of cloth saturated with isoamyl acetate is to be attached to the top portion of the bag. This procedure will produce a rough concentration of approximately $100 \mathrm{ppm}$ in the test atmosphere inside the plastic bag. Most people can detect isoamyl acetate as low as $0.1 \mathrm{ppm}$. The permissible exposure is $100 \mathrm{ppm}$.

The following isoamyl acetate fit-test will be performed as follows:

1. The wearer puts the respirator on normally. If it is an air-purifying device, it must be equipped with a cartridge(s) specifically designed for protection against organic vapors.

2. The wearer enters the test enclosure, so that his/her head and shoulders are well inside the bag.

3. If the wearer smells banana oil, he returns to clean air and readjusts the facepiece and/or adjusts the headstraps without unduly tightening them.

4. The wearer repeats the second step. If he does not smell banana oil, it is assumed he has obtained a satisfactory fit. If he smells the vapor, an attempt should be made to find the leakage point. If the leak cannot be located, another respirator of the same type and brand should be tried. If this also leaks, another brand of respirator with a facepiece of the same type should be tried.

5. After a satisfactory fit is obtained, the respirator must be equipped with the correct air-purifying filter(s), cartridge(s), or canister for the anticipated hazard.

During the test, the subject makes movements that approximate a normal working situation. This may include the following:

1. Normal breathing.

2. Deep breathing, as during heavy exertion. This should not be done long enough to cause hyperventilation.

3. Side-to-side and up-and-down head movements. These movements should be exaggerated but should approximate those that take place on the job.

4. Talking. This is most easily accomplished by reading a prepared text and/or reciting the alphabet loudly enough to be understood by someone standing nearby. 


\section{SUBJECT: RESPIRATORY PROTECTION}

5. Other exercises may be added depending on the situation. For example, if the wearer is going to spend a significant part of his time bent over at some task, it may be desirable to include an exercise approximating this bending.

The major drawback of the isoamyl acetate test is that odor thresholds varies widely among individuals. Furthermore, the sense of smell is easily dulled and may deteriorate during the test so that the wearer can detect only high vapor concentrations. Another disadvantage is that isoamyl acetate smells pleasant, even in high concentrations; consequently, a wearer may say that the respirator fits although it has a large leak. Test results must be checked carefully and confirmed by the next test atmosphere.

\subsubsection{Irritant smoke (stannic chloride) test}

This qualitative test is similar in concept to the isoamyl test. It involves exposing the respirator wearer to an irritating smoke. Sealed glass tubes, approximately $12 \mathrm{~cm}$ long by $1 \mathrm{~cm}$ in diameter, filled with pumice impregnated with stannic chloride are used to produce the smoke. When the tube ends are broken and air is allowed to enter, the material inside reacts with the moisture in the air to produce a dense, highly-irritating smoke.

As a qualitative means of determining respirator fit, this test has a distinct advantage in that the wearer usually reacts involuntarily to leakage by coughing or sneezing. The likelihood of the subject giving a false indication of proper fit is reduced; however, because this smoke is very irritating, it can cause problems for the test applicators or other persons in the same room. It is advisable to have good ventilation in the room in which the testing is to be conducted.

The irritant smoke test will be conducted by using a plastic garbage bag as a test hood. The bag shall be hung from the ceiling over a coat hanger suspended by rope. A small hole is made in the top portion of the bag so that the irritant smoke can be dispensed into the bag when the test subject has entered the bag.

The air-purifying respirator to be used in this test must be equipped with a high-efficiency, particulate filter.

The irritant smoke fit-test will be performed as follows:

1. The wearer puts the respirator on normally, taking care not to tighten the headstraps uncomfortably. Once the respirator is on, the subject is to enter the suspended bag so that his/her head and shoulders are well inside. 
MARTIN MARIETTA

ENERGY SYSTEMS, INC.

Oak Ridge National Laboratory
Pollutant Assessments Group

Health and Safety

Procedures Manual
Sect. 7 Rev. 2

Date $6 / 92$

Page 14 of 24

SUBJECT: RESPIRATORY PROTECTION

2. Once the subject is inside the bag, the tester may increase the smoke density, still remaining alert to the wearer's reactions.

3. If the wearer detects no leakage, the tester may increase the smoke density, still remaining alert to the wearer's reaction.

4. At this point, if no leakage has been detected, the wearer may cautiously begin the head movements and exercises mentioned in the isoamyl acetate test. The tester should remain especially alert and be prepared to stop producing smoke immediately and remove the subject from the bag.

5. If a leakage is detected at any time, the tester should stop the smoke and let the wearer out of the bag to readjust the facepiece or headstrap tension. The tester should then start the test at the second step.

6. If, at the end of all the movements and exercises, the wearer is unable to detect penetration of the irritant smoke into the respirator, the respirator wearer has a satisfactory fit.

7. After the test is completed, the subject should be removed from the test atmosphere.

\subsection{FTT-TESTING RESPIRATOR EXERCISE}

\subsubsection{Fit-Testing Personnel}

Participants learn to fit-test a full-face, air-purifying respirator with procedures suitable for field use after medical approval, respiratory training, and qualitative field testing have been performed by a certified respiratory protection program.

\subsubsection{Fit-Test Selection}

1. Instructor demonstrates proper fit-testing with isoamyl acetate and irritant smoke.

2. Each person must successfully fit-test at least one participant. It is desirable for each person to fit-test a full-face mask using both methods of testing.

3. Each participant must be fit-tested until a full-face mask is found that provides a good face seal.

4. The fit-test record, Fig. 7.1, must be completed. 
MARTIN MARIETTA

ENERGY SYSTEMS, INC.

Oak Ridge National Laboratory
Pollutant Assessments Group

Health and Safety

Procedures Manual
Sect. 7 Rev. 2

Date 6/92

Page 15 of 24

\section{SUBJECT: RESPIRATORY PROTECTION}

Name:

Location:

Signature:

Date:

Name of Fit-Tester:

Signature:

Date:

TYPE OF TEST

Type of Mask:

Manufacturer:

Model:

Type of Mask:

Manufacturer:

Model:

Type of Mask:

Pass/Fail Pass/Fail

Pass/Fail Pass/Fail

Pass/Fail Pass/Fail
ISOAMYL IRRITANT ACETATE SMOKE

Manufacturer:

Model:

Comments:

Fig. 7.1. Fit-test record. 


\section{SUBJECT: RESPIRATORY PROTECTION}

\subsection{RESPIRATOR INSPECTION AND MAINTENANCE}

\subsubsection{Respiratory Concerns}

Respirator maintenance is an integral part of the overall respirator program. Wearing a poorly maintained or malfunctioning respirator is, in one sense, more dangerous than not wearing a respirator at all. Personnel wearing defective devices think they are protected when, in reality, they are not. Emergency escape and rescue devices are particularly vulnerable to poor maintenance because they generally are used infrequently and, then, in the most hazardous and demanding circumstances. Serious injury or death can result from wearing a defective device during emergency escape or rescue.

\subsubsection{Inspection for Defects}

The most important part of a respirator maintenance program is continual inspection of the devices. If properly performed, inspections will identify damaged or malfunctioning respirators before they are used.

Two types of inspections will be performed: (1) while the respirator is in use and (2) while it is being cleaned. Because the use and cleaning will, to a large extent, be performed by the same personnel, these inspections may become concurrent.

\subsection{Office Inspection}

1. Tightness of connections on self-contained breathing apparatus.

2. Facepiece integrity.

3. Yalves in good operating condition.

4. Integrity of connecting tubes.

5. Canisters, filters, or cartridges stored in a cool, sanitary location.

In addition, the regulator and warning devices on a SCBA shall be checked for proper functioning.

\subsubsection{Field Inspection}

Routinely used air-purifying respirators will be checked as follows before and after each use. 
MARTIN MARIETTA

ENERGY SYSTEMS, INC.

Oak Ridge National Laboratory
Sect. 7 Rev. 2

Date $6 / 92$

Page 17 of 24

\section{SUBJECT: RESPIRATORY PROTECTION}

\subsubsection{Facepiece}

Examine the facepiece for

1. excessive dirt;

2. cracks, tears, holes, or physical distortion of shape from improper storage;

3. inflexibility of rubber facepiece (stretch and knead to restore flexibility);

4. cracked or badly scratched lenses in full facepieces;

5. incorrectly mounted full facepiece lenses or broken or missing mounting clips; and

6. cracked or broken air-purifying element holder(s), badly worn threads, or missing gasket(s).

\subsubsection{Headgear}

Examine the head straps or head harness for

1. breaks;

2. loss of elasticity;

3. broken or malfunctioning buckles and attachments; and

4. excessively worn serrations on head harness, which might permit slippage (full facepieces only).

\subsubsection{Exhalation valve}

After removing its cover, examine the exhalation valve for the following:

1. foreign material, such as detergent residue, dust particles, or human hair under valve seat;

2. cracks, tears, or distortion in the valve material;

3. improper insertion of the valve body in the facepiece;

4. cracks, breaks, or chips in the valve body, particularly the sealing surface;

5. missing or defective valve cover; and

6. improper installation of the valve in the valve body. 
MARTIN MARIETTA

ENERGY SYSTEMS, INC.

Oak Ridge National Laboratory
Pollutant Assessments Group

Health and Safety

Procedures Manual
Sect. 7 Rev. 2

Date $6 / 92$

Page 18 of 24

SUBJECT: RESPIRATORY PROTECTION

\subsubsection{Air-purifying elements}

Examine the air-purifying element(s) for

1. incorrect cartridge, canister, or filter for the hazard;

2. incorrect installation, loose connections, missing or worn gasket, or cross threading in the holder;

3. expired shelf-life date on the cartridge or canister;

4. cracks or dents on the outside case of the filter, cartridge or canister, indicated by the absence of sealing material, tape, foil, etc., over the inlet; and

5. identical cartridges if more than one are used.

\subsubsection{SCBA Care and Cleaning}

The proper care of SCBAs involves

1. inspection for defects,

2. cleaning and disinfecting,

3. repair, and

4. storage.

The following checklist is to be used by personnel whenever they have to check out an SCBA. (Note: Any discrepancy found should be cause to set the unit aside until it can be repaired by a certified repair person.)

\subsubsection{Preliminary inspection}

Check to ensure that

1. High-pressure hose connector is tight on cylinder fitting.

2. Bypass valve is closed.

3. Mainline valve is closed.

4. No cover or obstruction is present on the regulator outlet.

5. Pressure in the tank is at least 1800 psi. 


\section{SUBJECT: RESPIRATORY PROTECTION}

\subsubsection{Backpack and harness assembly}

1. Straps

a. Visually inspect for complete set.

b. Visually inspect for frayed or damaged straps that may break during use.

2. Buckles

a. Visually inspect for mating ends.

b. Check locking function.

3. Back plate and cylinder lock

a. Visually inspect back plate for cracks and for missing rivets or screws.

b. Visually inspect cylinder hold-down strap, and physically check strap tightener and lock to ensure that it is fully engaged.

7.6.5.3 Cylinder and cylinder valve assembly

1. Cylinder

a. Physically check cylinder to ensure that it is tightly fastened to back plate.

b. Check hydrostatic test date to ensure that it is performed monthly.

c. Visually inspect cylinder for large dents or gouges in metal.

2. Head and valve assembly

a. Visually inspect for presence of cylinder valve lock.

b. Visually inspect cylinder gauge for condition of face, needle, and lens.

c. Open cylinder valve and listen or feel for leakage around packing. (If leakage is noted, do not use until repaired.) Note function of valve lock.

\subsubsection{Regulator and high-pressure hose}

1. High-pressure hose Listen or feel for leakage in hose or at hose-to-cylinder connector. (Bubble in outer hose covering may be caused by seepage of air through hose when stored under pressure. This does not necessarily mean a faulty hose.)

2. Regulator and low-pressure alarm

a. Cover outlet of regulator with palm of hand. Open mainline valve and read regulator gauge (must read at least $1800 \mathrm{psi}$ and not more than rated cylinder pressure).

b. Close cylinder valve and slowly move hand from regulator outlet to allow slow flow of air. Gauge should begin to show immediate loss of pressure as 
MARTIN MARIETTA

ENERG 1 SYSTEMS, INC.

Oak Ridge National Laboratory
Pollutant Assessments Group

Health and Safety

Procedures Manual
Sect. 7 Rev. 2

Date 6/92

Page 20 of 24

SUBJECT: RESPIRATORY PROTECTION

air flows. Low-pressure alarm should sound between 650 and 550 psi.

Remove hand cornpletely from outlet and close mainline valve.

c. Place mouth onto or over regulator outlet and blow. A positive pressure should be created and maintained for 5 to $10 \mathrm{~s}$ without any loss of air. Next, establish a slightly negative pressure in regulator and hold for 5 to $10 \mathrm{~s}$.

Vacuum should remain constant. This tests the integrity of the diaphragm.

Any loss of pressure or vacuum during this test indicates a leak in the apparatus.

d. Open cylinder valve.

e. Place hand over regulator outlet and open mainline valve. Remove hand from outlet and replace in rapid movement. Repeat twice. Air should escape each time hand is removed, indicating a positive pressure in chamber. Close mainline valve and remove hand from outlet.

f. Ascertain that no obstruction is in or over the regulator outlet. Open and close the bypass valve momentarily to ensure flow of air through bypass system.

7.6.5.5 Facepiece and corrugated breathing tube

1. Facepiece

a. Visually inspect head harness for serrations and deteriorated rubber.

b. Visually inspect rubber facepiece body for signs of deterioration or extreme distortion.

c. Visually inspect lens for proper seal in rubber facepiece, proper placement of retaining clamp, and cracks or large scratches.

d. Visually inspect exhalation valve for visible deterioration or foreign materials buildup.

2. Breathing tube and connector

a. Stretch breathing tube and visually inspect for deterioration and holes

b. Visually inspect connector to ensure good condition of threads and for presence and proper condition of " $O$ " ring or rubber gasket seal.

c. Negative-pressure testing on the facepiece should be performed monthly.

(1) Don backpack and facepiece.

(2) With facepiece held tightly to face or facepiece properly donned, stretch breathing tube to open corrugations and place thumb or hand over end of connector.

(3) Inhale. Negative-pressure should be created inside mask, causing it to pull tightly to face. This negative-pressure should be maintained for 5 to $10 \mathrm{~s}$. If negative-pressure leaks down, the facepiece assembly is not adequate and should not be worn. 
MARTIN MARIETTA

ENERGY SYSTEMS, INC.

Oak Ridge National Laboratory
Pollutant Assessments Group

Health and Safety

Procedures Manual
Sect. 7 Rev. 2

Date $6 / 92$

Page 21 of 24

\section{SUBJECT: RESPIRATORY PROTECTION}

\subsubsection{Storage of units}

When storing units, check to ensure that

1. Cylinder is refilled as necessary and unit is cleaned and inspected.

2. Cylinder valve is closed.

3. High-pressure hose connector is tight on cylinder.

4. Pressure is bled off of the high-pressure hose and regulator.

5. Bypass valve is closed.

6. Mainline valve is closed.

7. All straps are completely loosened and laid straight.

8. Facepiece is properly stored to protect against dust, sunlight, heat, extreme cold, excess moisture, and damaging chemicals.

\subsubsection{Cleaning and Sanitizing}

Any good detergent may be used followed by a disinfecting rinse or a combination disinfectant-detergent for a one-step operation. Reliable, effective disinfectants may be made from readily available household solutions including:

1. Hypochlorite solution ( $50 \mathrm{ppm}$ of chlorine) made by adding approximately $2 \mathrm{~mL}$ of bleach (such as Clorox) to $1 \mathrm{~L}$ of water, or two tablespoons of bleach per gallon of water. A 2-min immersion disinfects the respirators.

2. Aqueous solution of iodine ( $50 \mathrm{ppm}$ of iodine) made by adding approximately $0.8 \mathrm{~mL}$ of tincture of iodine per liter of water, or 1 teaspoon of tincture of iodine per gallon of water. Again, a 2-min immersion is sufficient. To prevent damaging the rubber and plastic in the respirator facepieces, the cleaning water should not exceed $120^{\circ} \mathrm{F}\left(49^{\circ} \mathrm{C}\right)$.

\subsubsection{Rinsing}

The cleaned and disinfected respirators should be rinsed thoroughly in water $\left(120^{\circ} \mathrm{F}\right.$ maximum) to remove all traces of detergent and disinfectant. This is very important to prevent dermatitis. 
MARTIN MARIETTA

ENERGY SYSTEMS, INC.

Oak Ridge National Laboratory
Pollutant Assessments Group

Health and Safety

Procedures Manual
Sect. 7 Rev. 2

Date $6 / 92$

Page 22 of 24

SUBJECT: RESPIRATORY PROTECTION

\subsubsection{Drying}

The respirators may be allowed to dry in room air on a clean surface. They may also be hung from a horizontal wire, but care must be taken not to damage or distort the facepieces.

\subsubsection{Reassembly and Inspection}

The clean, dry respirator facepieces should be reassembled and inspected in an area separate from the disassembly area to avoid contamination. The inspection procedures have been discussed; special emphasis should be given to inspecting the respirators for detergent or soap residue left by inadequate rinsing. This appears most often under the seal of the exhalation valve and can cause valve leakage or sticking.

The respirator should be thoroughly inspected and all defects corrected. New or retested cartridges and canisters should be installed, and the completely reassembled respirator should be tested for leaks. For SCBA devices, the facepiece should be combined with the tested regulator and the fully charged cylinder, and an operational check should be performed.

\subsubsection{Maintenance and repair}

Replacement or repair of the respirator (only with parts designed for the respirator) shall be done only by trained, experienced persons. Besides being contrary to OSHA requirements, substitution of parts from a different brand or type of respirator invalidates approval of the device.

This restriction applies particularly to maintenance of the more complicated devices, especially SCBA and, more specifically, regulator valves and low-pressure warning devices. These devices should be returned to the manufacturer or to a trained technician for adjustment or repair. No problems are anticipated in repairing and maintaining most simple respirators, particularly the commonly used air-purifying type.

\subsubsection{Respiratory storage}

Respirators must be stored to protect against

1. dust,
2. sunlight, 
MARTIN MARIETTA ENERGY SYSTEMS, INC.

Oak Ridge National Laboratory
Pollutant Assessments Group

Health and Safety

Procedures Manual
Sect. 7 Rev. 2

Date 6/92

Page 23 of 24

\section{SUBJECT: RESPIRATORY PROTECTION}

3. heat,

4. extreme cold,

5. excessive moisture,

6. damaging chemicals, and

7. mechanical damage

Damage and contamination of respirators may take place if they are stored on a workbench, in a tool cabinet or tool box, among heavy tools, greases and dirt, or in a vehicle.

Freshly cleaned respirators will be placed in reusable plastic bags until reissue. They will be stored in a clean, dry location away from direct sunlight. They will be placed in a single layer with the facepiece and exhalation valve in an undistorted position to prevent rubber or plastic from taking a permanently distorted shape. Respirators will be checked and repaired or replaced as necessary per ANSI-Z88.2-1984.

\subsection{REFERENCES}

American National Standards Institute. 1984. NIOSH Certified Equipment List.

ANSI-Z88.2-1984. National Institute for Occupational Safety and Health, Washington, D.C.

Code of Federal Regulations-29, Pt. 1900-1910, 1990.

Code of Federal Regulations-30, Pt. 1-199, 1988.

DOE. 1985. Comprehensive Environmental Response, Compensation, and Liability Act Program.

DOE Order 5480.14. U.S. Department of Energy, Washington, D.C.

Condensed Chemical Dictionary-11th Ed., Revised by N. Irving Sax, Richard J. Lewis, Sr.

EPA 1981. Health and safety requirements for employees engaged in field activities. Environmental Protection Agency Order 1440.1. U.S. Environmental Protection Agency, July 12, 1981.

NIOSH. 1985. Occupational safety and health guidance manual for hazardous waste site activities. National Institute for Occupational Safety and Health, Occupational Safety and Health Administration, U.S. Coast Guard, and Environmental Protection Agency, DHHS (NIOSH) Publication 85-115, October 1985.

NIOSH. 1987. NIOSH Certified Equipment List. Publication 88-107. U.S. Department of Health and Human Services, Washington, D.C. October 1987.

Occupational Health Guidelines for Chemical Hazards, January 1981, Part 1 of 3, PB83-154609. 
MARTIN MARIETTA

ENERGY SYSTEMS, INC.

Oak Ridge National Laboratory
Pollutant Assessments Group

Health and Safety

Procedures Manual
Sect. 7 Rev. 2

Date $6 / 92$

Page 24 of 24

\section{SUBJECT: RESPIRATORY PROTECTION}

Occupational Health Guidelines for Chemical Hazards, January, 1981, Part 2 of 3, PB83-154609.

Occupational Health Guidelines for Chemical Hazards, January 1981, Part 3 of 3, PB83-154609.

Threshold Limit Values and Biological Exposure Indices for 1986-1987, QV-600-A54 1986-87-3 445600669694. 
MARTIN MARIETTA

ENERGY SYSTEMS, INC.

Oak Ridge National Laboratory
Pollutant Assessments Group

Health and Safety

Procedures Manual
Sect. 8 Rev. 2

Date 6/92

Page 1 of 50

SUBJECT: STANDARD OPERATING PROCEDURES

\section{STANDARD OPERATING PROCEDURES}

\subsection{PURPOSE}

The anticipated level of protection during drilling sequences at hazardous waste sites shall be determined by the SPM and SSHO after a PSI inspection and data evaluation have been performed.

\subsection{APPLICABIITY}

Prior to commencement of investigation activities, all site personnel will review health and safety requirements and contingency plans for their respective sites and assigned tasks. All site personnel must constantly be aware of changing working conditions and the welfare of work associates.

\section{EMERGENCY RESPONSE}

\subsection{Site Emergency Personnel}

If emergency medical facilities are not within a 10-min response time, all ORNL hazardous waste site investigation teams shall include at least one trained, qualified person to perform the duties of SSHO and at least one ORNL field technician per sample location or drilling site who is trained in first aid and cardiopulmonary resuscitation (CPR). In the event of serious injury, employees are to aid the victim only in accordance with their training and call for emergency evacuation to the nearest hospital. Notification will be given to off-site emergency response facilities of potential site-specific hazardous situations, and site personnel will be notified regarding local emergency phone numbers and directions to the nearest medical facilities prior to any site investigation activities.

APPROVED BY: 
MARTIN MARIETTA ENERGY SYSTEMS, INC. Oak Ridge National Laboratory
Pollutant Assessments Group

Health and Safety

Procedures Manual
Sect. 8 Rev. 2

Date 6/92

Page 2 of 50

SUBJECT: STANDARD OPERATING PROCEDURES

\subsubsection{Acute Hazardous Material Exposures}

Potential hazardous material exposures at the site shall be characterized by the SSHO. Dose-response relationships will be evaluated and included in the site-specific health and safety plan. Target levels correspond to OSHA PELs, which are concentrations or doses for a 8-h day, 40-h week below which no hazardous effect is observed. Toxicity effects are a function of the specific chemical agent, synergistic effects with other chemical agents, dose, route of exposure, and individual susceptibility as described in Sect. 5. Thus, for a full assessment of these potential hazards, each contaminant must be identified, the concentrations must be measured, the potential routes of exposure must be evaluated, and the overall health status of personnel must be medically reviewed. The possible exposure to personnel must be reviewed by Health Division staff. If this information on potential exposure is unavailable, the personnel protection recommendations shall be conservative to allow for missing toxicological information and, if sampling downgradient, contaminant migration information. If organic vapors (action levels) as measured on a PID exceed prescribed health and safety action limits above background levels at the breathing zone for $30 \mathrm{~s}$ or more, the CGI alarm sounds, or radiation limits are reached or exceeded, all personnel not wearing appropriate protective gear shall cease work and evacuate the work site, moving a minimum of $50 \mathrm{ft}$ upwind. Following a reasonable period, organic vapors will again be monitored at the borehole and at the breathing zone. If levels have subsided, drilling will recommence; if not, the site will be evacuated, the work plan will be evaluated and all pertinent health and safety protocols will be modified.

\subsubsection{Personnel Notification}

All personnel shall be immediately notified of known or suspected hazardous exposure levels (inhalation, skin, and ingestion) by the SSHO and/or any person experiencing or suspecting adverse health conditions.

\subsection{Emergency Contacts}

Should any situation of unplanned occurrence require outside or support services, regional emergency response help will be contacted. A prioritized list of appropriate contacts shall be included in the site safety plan. 
MARTIN MARIETTA

ENERGY SYSTEMS, INC.

Oak Ridge National Laboratory
Pollutant Assessments Group

Health and Safety

Procedures Manual
Sect. 8 Rev. 2

Date 6/92

Page 3 of 50

SUBJECT: STANDARD OPERATING PROCEDURES

\subsubsection{Emergency Procedures}

In the event that an on-site emergency develops, the procedures delineated herein are to be followed immediately.

1. Site entrance and/or exit routes, as designated by the SSHO or SPM, shall be used as emergency escape routes from the area or building if located upwind or at a safe distance to or beyond the contact of the contamination reduction zone and the exclusion zone from a hazardous source.

2. Visual on-site contact will be maintained, with the field crew remaining in proximity to assist each other in case of emergencies until everyone has safely evacuated the hazardous areas.

3. In the event that any member of the field crew is injured or experiences symptoms of exposure while on-site, the entire field crew should immediately halt work and follow instructions provided by the SSHO or SPM. Only certified personnel conforming to proper respiratory protection shall perform emergency rescues.

4. The discovery of any condition considered more hazardous than anticipated should result in the evacuation of the field team, notification and/or evacuation of nonsite personnel or members of the public who may be potentially affected, and reevaluation of the hazard and level of protection required.

5. The facility supervisor, if applicable, or local emergency response personnel should be notified.

6. Your name, title, phone number, location, and nature of situation should be provided to the appropriate emergency response provider.

7. If possible, first aid should be administered. Injured persons should be removed only if absolutely necessary, and flame should be extinguished or spills contained if possible.

8. Site personnel should remain at the scene, upwind and at a safe distance, to direct emergency personnel and provide information.

9. In the event that an accident occurs, the SPM or SSHO will, as soon as possible, follow appropriate Energy Systems reporting procedures and complete an Incident Response Form (Fig. 8.1) for submittal to the CPM and, if necessary, OSHA and other applicable contacts, with a copy to the ORNL Health and Safety Office. The SPM and CPM will ensure that follow-up actions are taken to mitigate the situation causing the accident and report, within $24 \mathrm{~h}$, any injuries involving five or more people and/or a death to the OSHA representative in the immediate area. 
MARTIN MARIETTA

ENERGY SYSTEMS, INC.

Oak Ridge National Laboratory
Pollutant Assessments Group

Health and Safety

Procedures Manual
Sect. 8 Rev. 2

Date 6/92

Page 4 of 50

\section{SUBJECT: STANDARD OPERATING PROCEDURES}

I. BEFORE RESPONSE

1. Incident: Site City State

Response Dates

2. Type of Response: Spill Fire Site Train other

3. Incident Safety Plan: Region Not Developed

4. Suspected chemical(s) involved: (a)

(c) (d)

5. Protective Level(s) involved: $A$

(a) If Level C - 1. Identify Canister

2. Describe air monitoring source(s)

(b) If Level $D$ JUSTIFY (in comments section at bottom of page).

6. SCBA-Identify Buddy: Name/Organization

7. Last Response: (a) Level Used:

$A$ B (b)

(b) Medical attention/exam performed: Yes D

II. AFTER RESPONSE

1. Protective Level Used: A B C

a. Level C - identify canister: b. Level D (comment below)

b. Level B or C skin protection: Tyvek/Saran_Acid/Rain other

2. List analysis chemical exposure: Same as above: (a) (b) (c) Unconfirmed

3. Equipment Decontamination: (a) clothing (b) respirator (c) monitoring Disposed: Cleaned:

No Action:

4. Appropriate time in exclusion area: hours per day for days

5. Was medical attention/exam required for this response: Yes No

Part i: Date Prepared: Prepared by:

Part II: Post Analysis Date Preparation: Reviewed By: COMMENTS : 
MARTIN MARIETTA

ENERGY SYSTEMS, INC.

Oak Ridge National Laboratory
Pollutant Assessments Group

Health and Safety

Procedures Manual
Sect. 8 Rev. 2

Date $6 / 92$

Page 5 of 50

SUBJECT: STANDARD OPERATING PROCEDURES

\subsection{HEALTH AND SAFETY CONTACT}

The SSHO, who is knowledgeable in all health and safety related functions as outlined in CFR 1910.120, shall be present during all site activities. The ORNL field representatives are responsible for daily checks of the work area operations. Any health and safety noncompliance items will be documented on the Health and Safety Checklist (Fig. 8.2) and immediately brought to the attention of the appropriate ORNL and/or subcontractor personnel for correction.

\subsection{TRAINING}

\subsubsection{All Site Workers}

If hazardous substance exposures are known or suspected to be equal to or greater than the PEL, all personnel at a hazardous material site must have appropriate classroom training and acceptable field training or comparable field experience that is documented according to 29 CFR 1910.120 (1-9) prior to performing any site activities. Topics will include, but will not be limited to, the following:

1. biological effects and exposure to chemicals/hazardous materials,

2. protective devices and techniques,

3. applicable standards,

4. worker responsibilities,

5. occupational safety and health,

6. basic personnel protection philosophy at chemical/hazardous sites,

7. procedures for donning and doffing protective clothing,

8. proper use of respiratory protection devices,

9. methods for decontamination of personnel and equipment/supplies, and

10. methods for site characterization and monitoring.

\subsection{Additional Training}

Maintenance of the mandatory skill levels will be by periodic refresher training. Managers and supervisors must have an additional $8 \mathrm{~h}$ of managerial training or documented comparable field experience and/or in-house training when they are directly responsible for hazardous waste site operations. Annual recertification consisting of $8 \mathrm{~h}$ hazardous waste training or documented field experience equivalent to training required in 29 CFR 19.10.120(e)(1-9) is required for all site personnel. Prior to any hazardous waste activities, a site-specific task and hazard briefing will be administered and documented. 
MARTIN MARIETTA

ENERGY SYSTEMS, INC.

Oak Ridge National Laboratory
Pollutant Assessments Group

Health and Safety

Procedures Manual
Sect. 8 Rev. 2

Date 6/92

Page 6 of 50

\section{SUBJECT: STANDARD OPERATING PROCEDURES}

MEALTH AND SAFETY CHECKLIST

Sheet__ of Subcontractor(s)

Date Time Location Site Location

Techniciens Name ITEY

Fard hats and safety glasses born

Itecher/safety shoes born

A.ll wickers trained

Dosirieters worn

Sefety Equipiient is sted

"̈ork erea restrlet!ons follei-ed

First a!d kit svaliable

Fire extinguisher evallable

Ried survey frisking edequate

Decon equibient avalieble

Proper jecon oneracions

Proper use of profectlve equiment

Proner use of respiretors

Ireffic restrictions obsenied

Dust conicol ansronriate

Protier haulaze techniaues observed

Vehicles in sood exerasing condition

Equipient storage aderuate

A.C heat in safe cperating condiclon

:ioise below sefe levels

Vibration estimated to be safe

Lishting adeouate

HousekeED!nB enproprlate

Sefety precautions for public

Walkezys clear of obstructions

Sinns and sefety posters adeouate

Hazarbous raferial storege adecuate

F-iersency exits ajequate

Fire hazards marked end guarded

Break areas in safe locations

Falline oblects secured

Stress factors reccentied

Elecerical safeguards in place

Machinery safeguards in place

Eurning permits secured

Siop tork order recomererded

* *iork records submitted

+*Persongel ronl:ors refurned

tarestrlcted site access arroved

stheculed as reculred

noher

\begin{tabular}{|c|c|}
\hline \multirow[t]{3}{*}{ 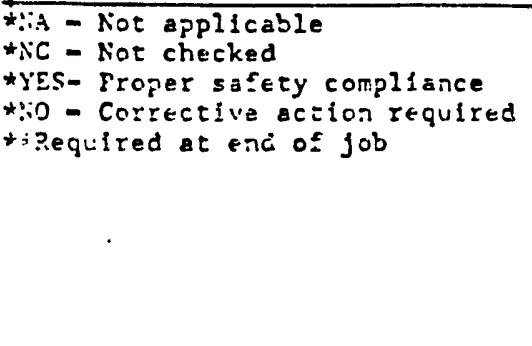 } & $\begin{array}{ll}\text { Distribution: } & \text { Project Manager } \\
\text { For Corrective } & \text { Health \& Safecy officer } \\
\text { Action: } & \text { Project Manager } \\
& \text { Subcontrace Supervisor }\end{array}$ \\
\hline & Froject Manäger \\
\hline & Suliconeract S lpervisor \\
\hline
\end{tabular}

Fig. 82. Health and safety checklist. 
MARTIN MARIETTA

ENERGY SYSTEMS, INC.

Oak Ridge National Laboratory
Pollutant Assessments Group

Health and Safety

Procedures Manual
Sect. 8 Rev. 2

Date $6 / 92$

Page 7 of 50

\section{SUBJECT: STANDARD OPERATING PROCEDURES}

Personnel training documentation is kept on file at the ORNL QA office located in Grand Junction, Colorado.

\subsubsection{Training Checklist}

The hazardous site training checklist (Fig. 6.4) will be completed and included with each site safety plan, thus indicating the training received by on-site personnel. All personnel must become familiar with the capabilities of each team member, as displayed by this matrix, to minimize response times in the event that emergency action is required.

\subsubsection{Task Training}

Site personnel will receive adequate training for all assigned tasks. Periodic refresher training for performing special tasks shall be maintained. Supplemental training shall be considered for unusual site activities such as container opening, confined-space entry, emergency rescue, and sediment sampling. Simulated exercises will be performed to help train field investigators to perform these tasks safely and more efficiently.

\subsection{Rescue Training}

All personnel required to wear respirators must be fit-tested and receive training for respiratory protection. A minimum of two persons per site will be adequately fit-tested for respiratory protection and properly trained for rescue requirements if any hazardous breathing concentrations are evident or even remotely suspected.

\subsubsection{Site Visitors}

Nonessential personnel shall be kept off-site. Occasionally, an untrained individual may desire or be required to visit a site to inspect or observe conditions or activities. The site safety plan will clearly describe measures to protect these visitors. Site projects shall prohibit visitors in the exclusion and contamination reduction zones until they have completed the entire training program. Other programs may prescribe an abbreviated training program for visitors and restrict their activities and access to the site. Unless visitors observe outside the exclusion and contamination reduction zones, they will be included in a medical surveillance program if it is suspected that hazardous conditions may have an effect on them. Newly assigned personnel and visitors with site-specific prescribed training must request permission and personal protection requirements from the SSHO or SPM for entry into areas with potential hazards. 
MARTIN MARIETTA

ENERGY SYSTEMS, INC.

Oak Ridge National Laboratory
Pollutant Assessments Group

Health and Safety

Procedures Manual
Sect. 8 Rev. 2

Date $6 / 92$

Page 8 of 50

\section{SUBJECT: STANDARD OPERATING PROCEDURES}

All nonassigned, untrained site visitors and/or transient workers must be over 18 years of age and shall be escorted by the SPM, SSHO, or other designated trained person while at the site. The SPM must verify that all ORNL and subcontracted personnel assigned to the site meet ORNL safety training requirements.

\subsubsection{Subcontractor Personnel}

Special service contractors, such as well drillers, heavy-equipment operators, and surveyors, shall be required to show proof that all employees who may have the potential of hazardous exposures while working on or near a hazardous waste site or who will handle potentially contaminated material from a site (samples, tools, or equipment) have received appropriate medical examinations. These workers shall be required to have completed an adequate hazardous waste training program conducted by qualified instructors and to provide proof of this and/or equivalent additional documented task-specific training.

\subsubsection{PSI Training}

The following outline will be used by the SSHO for PSI training of personnel who will be working on the project site:

\section{Site Review and Work Plan}

- Site maps

- Pertinent site history

- Work description

\section{General Field Safety Techniques}

- Responsibilities

- Medical program

- Site work zones

- Vehicle operation and parking

- Site air monitoring

- Potential hazardous contaminants present at the project site and chemical hazards at specific sites (toxicity and symptomatology)

- Contingency plans and responses

- Use of field equipment and supplies (Project Work Plan Standard Operating Procedures)

- Drilling equipment

- Work tools 
MARTIN MARIETTA

ENERGY SYSTEMS, INC.

Oak Ridge National Laboratory
Pollutant Assessments Group

Health and Safety

Procedures Manual
Sect. 8 Rev. 2

Date 6/92

Page 9 of 50

\section{SUBJECT: STANDARD OPERATING PROCEDURES}

- Sampling equipment

- Monitoring equipment

- Site control and security

- Buddy system and hand signals

- Work limitations

- Hours of work

- Light conditions

- Weather

Personal Protective Equipment and Clothing

- General

- Availability

- Hearing protection devices

- Personal protective equipment and clothing for Level D operations including information about the limitations of protection

- Work clothing

- Eye protection

- Foot protection

- Head protection

- Hearing protection

- Personal protective equipment and clothing for Level $\mathrm{C}$ operations including information on the limitations of protection

- Respiratory protection (selection, fit testing, donning, and use)

- Work clothing

- Eye protection

- Foot protection

- Head protection

- Hearing protection

- Donning/doffing procedures

- Decontamination of clothing and equipment

- Disposal of contaminated clothing and equipment

Emergency Assistance

- Availability of emergency services and location of telephone numbers

- Transportation of emergency cases

- First aid/CPR

- On-site emergency assistance and review of hand signals 
MARTIN MARIETTA

ENERGY SYSTEMS, INC.

Oak Ridge National Laboratory
Pollutant Assessments Group

Health and Safety

Procedures Manual
Sect. 8 Rev. 2

Date 6/92

Page 10 of 50

\section{SUBJECT: STANDARD OPERATING PROCEDURES}

\section{Special Precautions During Investigation Operations}

- Most dangerous times

- During movement of heavy equipment

- During lifting of large, heavy loads

- Most dangerous conditions

- Using heavy equipment near overhead electrical power lines

- Raising large, heavy loads

The SSHO will maintain a file of completed plan acceptance forms from each worker indicating that he/she has read and understands the health and safety plan and has attended the appropriate training. In addition, the SSHO will conduct tailgate safety meetings whenever new personnel arrive at the site and as significant changes to site or work conditions occur.

\subsection{SITE WORK CONTROL}

\subsubsection{Site Entry Authorization}

All personnel entering a potential hazardous waste site shall be preauthorized and have received training as required by 29 CFR 1910.120(e)(1-9). The only exception to this requirement is the utilization of emergency personnel under the directives of the SSHO or confirmation that the site is free of hazards. Accountability records will be kept in an entry log maintained by the SSHO, and all site personnel will sign in and out upon entry and egress.

Site entry and exit shall be documented by the SSHO or his designated representative in the field project logbook. Vehicular travel shall be restricted to designated roads only. Routes shall be agreed on prior to the start of the project and shall be based on the capabilities of the subcontractor's equipment. Spark arresters and explosion-proof ignition systems will be required for vehicles and other motorized equipment when operating near fuel storage areas or similar types of combustible atmospheres.

\subsubsection{Initial Site Determination Procedures}

Considerable knowledge of site history and current status allows the preparation of a site safety plan with reasonable assurance that personnel are adequately protected. In the event that sufficient site information is not available to perform a summary risk assessment and assign the appropriate level of personal protective equipment, the following 
MARTIN MARIETTA ENERGY SYSTEMS, INC.

Oak Ridge National Laboratory
Pollutant Assessments Group

Health and Safety

Procedures Manual
Sect. 8 Rev. 2

Date 6/92

Page 11 of 50

SUBJECT: STANDARD OPERATING PROCEDURES

procedures should be followed. It must be understood that verification of the level of contamination (even with background information) will always require some of these steps.

1. Recognize that the presence of on-site hazardous waste implies a perceived contamination potential by the client.

2. Assume that the site is contaminated and conduct a site safety entrance reconnaissance. That is, the SSHO will continuously monitor air levels with the prescribed monitoring equipment, cautiously entering upwind of the suspected hazardous site. Only after the types of hazards have been determined can the SSHO and other site personnel enter the site to

- establish contamination reduction and exclusion zones.

- survey the site with specified monitoring equipment, beginning with a perimeter survey and gradually covering all areas of proposed activity. This shall be performed using the highest level of personnel protection practicable.

3. Prepare a site safety plan summary and document all data acquired. At a minimum, use chemical hazard data and MSDSs to develop site-specific health and safety requirements as mandated by OSHA: 29 CFR Pt. 1910, subpart 2, NIOSH "Recommendations for Occupational Health Standards, "September 1986, and American Conference of Governmental Industrial Hygienists, "Threshold Limit Values and Biological Exposure Indices for 1986-87."

\subsubsection{Performing tasks in a confined space}

All confined spaces will be tested and documented by qualified persons, whose certification mandated by 29 CRF 1910.120 is current and who have received approved training for confined-space monitoring, rescue, and entry, before access by any confinedspace personnel to determine whether the confined space atmosphere is safe for entry. The buddy system will be used for tests that consist of monitoring oxygen level, flammability, and known or suspected hazardous materials. Evaluation of the confined space should consider the following:

- methods for isolating the space by mechanical or electrical means (i.e., double-block mechanical equipment and bleed pressurized lines, lockout, tag-out, etc.);

- the institution of lockout-tagout procedures;

- posted evaluation checklist, including confined-space hazard ranking (low, medium, high);

- observer (nonentry);

- ventilation of the space;

- cleaning and/or purging; 
MARTIN MARIETTA

ENERGY SYSTEMS, INC.

Oak Ridge National Laboratory
Pollutant Assessments Group

Health and Safety

Procedures Manual
Sect. 8 Rev. 2

Date 6/92

Page 12 of 50

\section{SUBJECT: STANDARD OPERATING PROCEDURES}

- work procedures, including use of safety lires operated from a winch support attached to the person working in the confined space and by a standby person if trouble develops;

- personal protective equipment required (clothing, respirator, boots, etc.),

- special tools required; and

- communications system to be used.

The confined space should be continuously monitored if it is ranked as a high hazard to determine whether the atmosphere has changed as a result of the work being performed (if such work potentially introduces a hazard).

\subsubsection{Rescue training for confined space}

Rescue procedures will be established and practiced before entry and will be specific for each type of confined space. A standby observer, donning the same personal protective equipment (PPE) as the entry personnel, will be assigned for each entry. The standby observer will be equipped with rescue equipment including a safety line attached to the worker in the confined space, self-contained breathing apparatus and protective clothing as specified in the site-specific health and safety plan. The standby observer should use this safety line, attached to a winch if necessary, to help rescue the worker and should summon help but does not enter the confined space. The rescue procedures will be practiced previously to provide a level of proficiency that eliminates the need for life-threatening rescue attempts and ensures an efficient and calm response to any emergency.

\subsubsection{Site Safety Equipment}

In addition to personnel protective gear designated for the assigned level, various monitoring and safety equipment will be maintained on-site. Minimum on-site equipment will generally include:

- photoionization meter;

- CGI (explosimeter, oxygen/low flammability meter);

- chemically reactive indicating tubes (specific to the site hazards);

- fire extinguishers;

- first-aid kits;

- eye-wash station;

- sound-level meter, if a suspected need is perceived;

- radiation survey meters;

- transportation suitable for emergency response; 
MARTIN MARIETTA

ENERGY SYSTEMS, INC.

Oak Ridge National Laboratory
Pollutant Assessments Group

Health and Safety

Procedures Manual
Sect. 8 Rev. 2

Date $6 / 92$

Page 13 of 50

SUBJECT: STANDARD OPERATING PROCEDURES

- gas chromatograph (optional); and

- organic vapor analyzer (optional).

Additional equipment may be specified and obtained as field conditions dictate.

\subsubsection{Construction Safety}

1. All visitors and workers shall wear eye protection (safety glasses, goggles, or shields) and hard-toed safety boots when perceived hazards associated with these protective equipment needs exist as mandated by 29 CFR 1910/1926. In addition, hard hats shall be worn while within a 50-ft perimeter of drilling or other heavy equipment. Additional equipment and training necessary for a specific site will be included in the site safety plan.

2. If toilet facilities are not readily available, adequate portable toilet facilities will be provided for use by on-site personnel.

3. The ORNL/CAT SPM shall verify removal of all refuse generated during the program and properly dispose of it in accordance with applicable regulatory mandates.

4. All machinery with impeded rear view vision shall be equipped with a reverse signal alarm distinguishable from the surrounding noise level or an employee shall be designated as a signal person to ensure safe movement. The perimeter of motorized vehicles will be checked for hazards and equipment clearance prior to movement. Drill rigs shall not be moved with the mast elevated, nor shall a drill rig mast be raised within $10 \mathrm{ft}$ of any overhead power lines (Table 8.1).

5. Personnel will be required to use seat belts in all site investigation vehicles that have them.

6. An adequate first-aid kit and 10-lb National Fire Protection Association (NFPA) approved $A B C$ chemical fire extinguisher shall be kept in $20 \mathrm{ft}$ proximity of all personnel.

7. Barricades and/or signs will be used to isolate all hazardous conditions. Amber warning lights will be used for exposing hazardous conditions at night, except when in proximity to airport runways, which may require blue warning lights, if so dictated by the airport authority. 
MARTIN MARIETTA

ENERGY SYSTEMS, INC.

Oak Ridge National Laboratory
Pollutant Assessments Group

Health and Safety

Procedures Manual
Sect. 8 Rev. 2

Date 6/92

Page 14 of 50

SUBJECT: STANDARD OPERATING PROCEDURES

Table 8.1. Safe working distances from electrical transmission lines for drill rigs

\begin{tabular}{cc}
\hline $\begin{array}{c}\text { Normal voltage } \\
\text { (phase-to-phase) }\end{array}$ & $\begin{array}{c}\text { Minimum required } \\
\text { clearance }\end{array}$ \\
\hline to $50 \mathrm{kV}$ & $10 \mathrm{ft}$ \\
Over 50 to $200 \mathrm{kV}$ & $17 \mathrm{ft}$ \\
Over 200 to $350 \mathrm{kV}$ & $22 \mathrm{ft}$ \\
Over 350 to $500 \mathrm{kV}$ & $27 \mathrm{ft}$ \\
Over 500 to $750 \mathrm{kV}$ & $35 \mathrm{ft}$ \\
Over 750 to $1000 \mathrm{kV}$ & $44 \mathrm{ft}$ \\
\hline
\end{tabular}

Note: While in transit with mast lowered, the clearance shall be a minimum of $10 \mathrm{ft}$.

\subsection{Monitoring Well Safety}

1. Pressurized tanks, gauges, and hoses will be used only by adequately trained personnel, according to ANSI and NIOSH/MSA guidelines. Gauges, fittings, and hoses used shall be capable of and approved for handling working pressures in excess of all associated pressurized gas and/or fluid systems specific to a project, and worn or damaged parts will be repaired or ceplaced.

2. Handling, preparation, and installment of concrete, silicate sand, bentonite, and other materials used for well installation will be performed with adequate protective clothing and ventilation with respect to the material being handled.

3. Portable generators and pumps and other motorized equipment will be refueled by pouring fuel from safety cans only when the equipment is not operating.

4. Refueling shall be conducted away from all sources of ignition and a NFPAapproved dry-chemical fire extinguisher will be kept within $25 \mathrm{ft}$ of equipment.

5. Only NFPA-approved refueling systems shall be used for transferring fuel to internal combustion engines.

6. All electrical equipment and extension cords shall have three-pronged grounding plugs and be capable of handling the prescribed working load.

7. All motorized and electrical equipment, especially drill rigs, will have emergency shut-off capabilities.

8. Personnel access to investigation sites and monitoring wells shall be restricted to authorized personnel only. The site will be fenced and properly posted if deemed necessary by the SSHO, SPM, and/or the site safety plan. Monitoring wells will have locking well caps to avoid possible exposure to unsuspecting civilians or site personnel or vandalism to wells. 
MARITN MARIETTA

ENERGY SYSTEMS, INC.

Oak Ridge National Laboratory
Pollutant Assessments Group

Health and Safety

Procedures Manual
Sect. 8 Rev. 2

Date $6 / 92$

Page 15 of 50

\section{SUBJECT: STANDARD OPERATING PROCEDURES}

\subsubsection{Slope Sampling Safety}

Soil sampling performed on steep inclines with the potential hazard of slipping and/or falling more than $6 \mathrm{ft}$ will require the use of safety belts, lanyard ropes, and associated equipment. This equipment shall be used only by adequately trained personnel knowledgeable in the use of climbing and dangerous-height safety equipment. As mandated by 29 CFR 1926.104, safety belts, lanyards (belt rope with end couplers), and hardware shall be capable of withstanding a tensile loading of $\mathbf{4 0 0 0} \mathrm{lb}$ without developing cracks, permanent deformation, or breaking. Two lifelines and an anchoring support with respective minimum breaking and support strengths of $5400 \mathrm{lb}$ will be used for actual bearing of the full weight of any person. Safety equipment will be selected for site-specific, reactive needs. In most situations nylon rope that is strongly resistant to most chemicals, heat, and abrasion will be used.

Nylon lifelines having almost twice the shock load capability of most other types of rope and having minimum safety factor of 15 times the work load including rope weight, has been established by the NFPA for safety ropes, harnesses, and hardware. All safety equipment tested by this standard will have NFPA identification markings on it.

Slope sampling should be performed only when conditions are proved to be as safe as possible. Any chemicals used on-site (especially acids and alkalies) will not be allowed to come in contact with lifelines or any other safety equipment. Safety equipment proven or suspected of being damaged or contaminated shall be replaced. Sharp or abrasive objects should be kept from contacting lifelines. Durable, cleated boots will be worn for necessary traction. No personnel shall work directly above or below other personnel when the risk of rock or dirt slides or any other falling objects is present.

\subsubsection{Excavation Requirements}

All utilities will be located and a permit will be obtained prior to excavation, soil penetration, or drilling. During excavation, any underground utilities that are uncovered will be supported as mandated by OSHA, 29 CFR 1926.651. Excavations and trenches over $5 \mathrm{ft}$ in depth where personnel are working shall have slopes no steeper than a 1-ft vertical rise to each 0.5 -ft horizontal run; excavated materials shall be effectively retained at least $\mathbf{2} \mathrm{ft}$ from the edge, and/or shoring will be installed if needed.

Supporting systems using cribbing, concrete retaining walls, piling, etc., can be used for slope retention in lieu of slope gradient requirements. Support systems will be designed by a qualified person and will meet accepted engineering requirements as described in 29 CFR 1926, Subpart P, and other associated mandates. 
MARTIN MARIETTA

ENERGY SYSTEMS, INC.

Oak Ridge National Laboratory
Pollutant Assessments Group

Health and Safety

Procedures Manual
Sect. 8 Rev. 2

Date $6 / 92$

Page 16 of 50

\section{SUBJECT: STANDARD OPERATING PROCEDURES}

Excavations and trenches shall be monitored daily for hazardous breathing levels and possible cave-ins. Warning barriers will be placed around the entire excavation, or the pit shall be covered or backfilled. Personnel working in excavations shall wear a hard hat. A safety harness with an attended lifeline and breathing apparatus shall be readily available if hazardous atmospheric levels are suspected. An adequate breathing apparatus will be available for rescue personnel.

\subsubsection{Water Safety}

If the possibility of drowning is present during water or sediment sampling, Coast Guard approved life vests shall be worn. A lifeline and harness shall be used if deemed necessary by the SSHO.

\subsubsection{Noise Control}

If employees are subjected to noise exceeding an 8-h TWA sound level of $85 \mathrm{dBA}$ (decibels on the A-weighted scale), feasible administrative or engineering controls must be utilized (hearing protection will be required). During operation of heavy-equipment and/or aircraft maneuvers, exposure to potentially damaging noise may be expected. Hearing protection shall be available, and its use encouraged for personnell working on the site if $85 \mathrm{dBA}$ is not exceeded. In addition, whenever employee noise exposures equal or exceed an 8-h TWA sound level of $85 \mathrm{dBA}$, employers must aldminister a continuing, effective hearing conservation program as described in OSHA regulation 29 CFR 1910.95 (Table G-16a).

\subsubsection{Radio Control}

All two-way radio communication shall be in accordance vrith the Federal Communication Commission (FCC), state, and applicable local regulations. Two-way radios shall not be used near underground fractionating operalions, surface blasting operations, or explosive storage areas. The use of any unauthisrized electronic equipment or personal radios is prohibited when personnel are working on or around the site. Two-way radios shall be used only when permitted by site security officials or as dictated by the SPM. 
MARTIN MARIETTA

ENERGY SYSTEMS, INC.

Oak Ridge National Laboratory
Pollutant Assessments Group

Health and Safety

Procedures Manual
Sect. 8 Rev. 2

Date 6/92

Page 17 of 50

SUBJECT: STANDARD OPERATING PROCEDURES

\subsubsection{Levels of Protection}

The level of protection will be prescribed by the types of hazards associated with specific sites, decontamination materials, and sample preservation agents.

\subsubsection{Work Zones}

All work shall proceed within a designated zone to prevent the possible spread of contamination and shall include all drilling, decontamination, sampling, and associated activities.

The respective zones of all field personnel shall be transmitted to security and/or emergency medical staff at all sites when extreme hazardous conditions are perceived to be a possible health or safety threat to these personnel during an emergency situation.

The following sections apply to the determination of work zones.

\subsubsection{Zone 1: Exclusion zone}

The exclusion zone is the zone where the potential of coming into contact with contamination is greatest (Fig. 8.3). Additionally, the exclusion zone will, at the least, consist of the known or suspected limits of contamination. If these limits are unknown, then the zone will be determined by the radial distance of the drill mast height during drilling operations or $50 \mathrm{ft}$ during all other operations. All personnel entering the exclusion zone will have the prescribed level of protective clothing and training and will receive the level of medical surveillance established by the SSHO. An entry and exit check point will be visually defined at the periphery of the exclusion zone to regulate the flow of personnel and equipment into and out of the zone. Personnel assigned to this zone will consist of a driller, driller's helper, SSHO, and a minimum of one other person. PID and CGI monitoring will be performed continuously by the SSHO in the exclusion zone where hazardous atmospheric conditions are suspected to exist. Prohibited items or conduct in the exclusion zone include the following:

- eating, smoking, or the chewing of anything;

- application of insect spray or cosmetics;

- working when ill;

- complete removal of respiratory protective equipment under Level $\mathrm{C}$ or higher protection;

- access to the exclusion zone by any individual not having the required health and safety training in accordance with 29 CFR 1910.120(e)1 and (e)2; 
MARTIN MARIETTA

ENERGY SYSTEMS, INC.

Oak Ridge National Laboratory
Pollutard Assessments Group

Health and Safety

Procedures Manual
Sect. 8 Rev. 2

Date 6/92

Page 18 of 50

\section{SUBJECT: STANDARD OPERATING PROCEDURES}

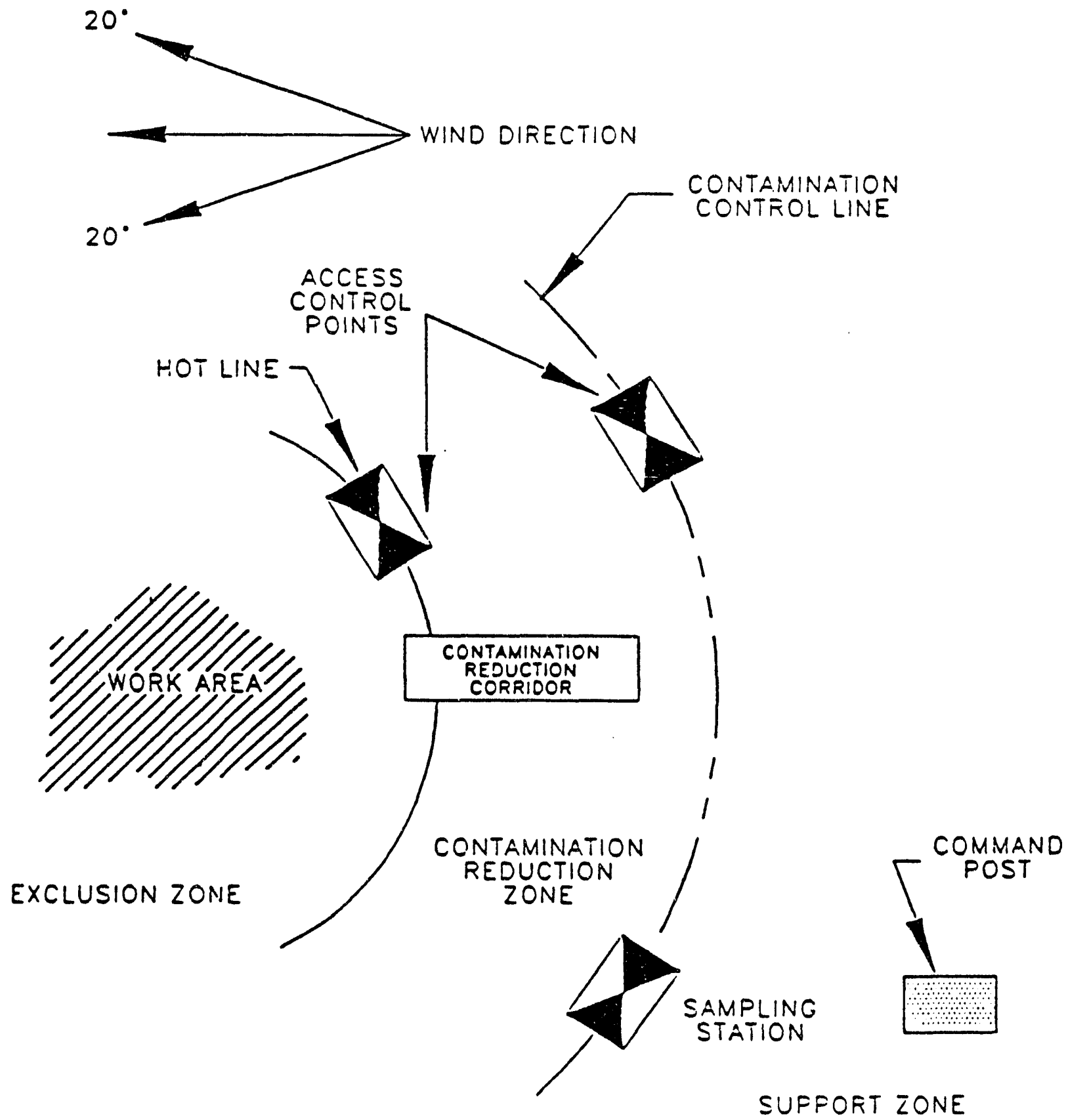

Fig. 8.3. Diagram of site work zones. 
MARTIN MARIETTA ENERGY SYSTEMS, INC.

Oak Ridge National Laboratory
Pollutant Assessments Group

Health and Safety

Procedures Manual
Sect. 8 Rev. 2

Date 6/92

Page 19 of 50

\section{SUBJECT: STANDARD OPERATING PROCEDURES}

-individuals that do not possess the site training to gain entrance to the site or;

- any conduct or item thought to be potentially dangerous to the well being of site personnel or the drilling subcontractor.

\subsubsection{Zone 2: Contamination reduction zone}

As shown in Fig. 8.3, a contamination reduction zone will be established outside the exclusion zone. This zone provides a transition between the exclusion zone (potentially contaminated zone) and the support zone (clean zone). It serves as a buffer to further reduce the possibility of the support zone becoming contaminated. It provides additional assurance that the physical transfer of contaminated substances on personnel or equipment or in the air is limited through a combination of decontamination, distance between exclusion and support zones, air dilution, zone restriction, and work functions. At the boundary between the exclusion and contamination reduction zones, a soil preparation station will be established, and decontamination stations for the purpose of personnel and sampling equipment decuntamination will be established. Equipment decontamination will be accomplished as described in Sect. 6.2 of this document. The personnel decontamination station will be constructed as detailed in the personnel decontamination section of the site health and safety plan. Personnel in this zone will consist of a sampler and a geologist. The SSHO will assist with decontamination requirements. A PID and/or other appropriate monitoring equipment will be used for screening soil samples for volatiles, radiation, etc., when suspected. Prescribed meters will be continuously used to monitor all potentially hazardous areas and soil samples until the determination of a safe working environment dictates only the need for periodic monitoring or cessation.

\subsubsection{Zone 3: Support zone}

The support zone (Fig. 8.3) will be upwind and, if possible, uphill and protected against contamination from the work site. Primary functions of the support zone are as follows:

- the entry point for personnel, materials, and equipment;

- the exit point for decontaminated personnel, materials, and equipment;

- a storage area for clean materials and equipment; and

- an area for rest breaks, the consumption of food and beverage, and all other activities, including a nontrained visitor's observation point. 
MARTIN MARIETTA

ENERGY SYSTEMS, INC.

Oak Ridge National Laboratory
Pollutant Assessments Group

Health and Safety

Procedures Manual
Sect. 8 Rev. 2

Date 6/92

Page 20 of 50

SUBJECT: STANDARD OPERATING PROCEDURES

\subsubsection{Worker Safety Procedures}

Workers will be expected to adhere to established safety practices for their respective specialties (e.g., sampling, drilling, laboratory analysis, and construction). The need to exercise caution in performing specific project tasks is made more acute as a result of adverse weather conditions, restricted mobility, and reduced peripheral vision caused by the protective gear itself, the need to maintain the integrity of the protective gear, and the increased difficulty in communicating caused by respirators, if worn. Work at waste site investigations will be scheduled to allow for difficult working conditions including additional precautionary measures for the safety and health of all people involved. Among the most important principles for working at the hazardous waste site are:

1. In an unknown situation, always assume the worst conditions and plan responses accordingly.

2. Employ the buddy system. Establish and maintain communication. If it is impractical to use radio communications, it is advisable to develop a set of hand signals because conditions may greatly impair verbal communications.

3. Minimize contact with excavated or contaminated materials. Plan work areas, decontamination areas, and procedures to accomplish this. Do not place equipment on drums or on the ground. Do not sit or kneel on potentially contaminated soil, drums, or drilling equipment.

4. Employ disposable items, when possible, to minimize risk incurred by decontamination and possible cross-contamination during sample-handling. This will require a common-sense approach to potential risk and cost.

5. Smoking, eating, or drinking after entering the work zone and before decontamination will not be allowed. Oral ingestion of contaminants is the most likely means of introducing toxic substances into the body (inhalation being secondary).

6. Avoid heat and other work stresses related to wearing protective gear. Work breaks should be planned to prevent fatigue or stress-related accidents. The SSHO will monitor all personnel for degrading health conditions.

7. Maintain monitoring systems. If subsurface areas of contamination are penetrated, conditions can change quickly.

8. Conflicting situations may arise concerning safety requirements and working conditions and must be addressed and resolved rapidly by the SSHO and SPM to relieve any motivations or pressures to circumvent established safety policies.

9. Unauthorized breaches of specified safety protocol will not be a:lowed. Personnel unwilling or unable to comply with the established procedures will be replaced. Any changes in established procedure will be documented. The change should have a very specific, valid basis and must be approved by the SSHO and SPM. 
MARTIN MARIETTA

ENERGY SYSTEMS, INC.

Oak Ridge National Laboratory
Poliutant Assessments Group

Health and Safety

Procedures Manual
Sect. 8 Rev. 2

Datc $6 / 92$

Page 21 of 50

SUBJECT: STANDARD OPERATING PROCEDURES

10. Be observant of your immediate surroundings and the surroundings of others. Everyone will be working under constraints of awareness, and it is a team effort to notice and warn of impending dangerous situations.

11. Use of contact lenses on-site will not be allowed when dictated by working conditions. Eye-washing facilities with the potential of 20-min operation need to be available should corrosive or lachrymose substances enter the eyes of personnel.

12. Sites potentially requiring Level C, B, or A protection will require the removal of facial hair (except trimmed moustaches) to allow a proper facepiece fit.

13. Site-specific contingency planning and dissemination of plans to all site and emergency response personnel minimizes the impact of rapidly changing safety protocols in response to changing site conditions.

14. Withdrawal from a hazardous situation to reassess procedures is the preferred course of action.

15. Be aware that chemical contaminants may mimic or enhance symptoms of other illnesses or intoxication. Avoid use of alcohol and working with an illness during field investigation assignments.

16. The SPM, SSHO, and other assigned personnel shall maintain recurds in a bound notebook, recording daily activities, including site access and egress, meetings, facts, incidents, data, etc., relating to the project. These record books will remain on-site during the full duration of the project so that replacement personnel may add information in the same book, maintaining continuity. These notebooks and daily records will become part of the permanent project file and archived in the ORNL Central Research Library.

\subsection{DECONTAMINATION}

\subsection{Personnel Decontamination}

All hazardous waste sites will be provided with adequate equipment and water for removing known or suspected radioactive and/or chemical contamination from personnel as stated in the site-specific work plan or health and safety plan. After exiting the exclusion zone, personnel are not to eat, drink, smoke, chew gum or tobacco, or apply cosmetics without first thoroughly decontaminating personal protective clothing and washing their hands. If radiation contaminants are a potential risk, frisking will be performed. This process will be repeated until it can be verified that radiation contaminants will not be transferred from the site. 
MARTIN MARIETTA

ENERGY SYSTEMS, INC.

Oak Ridge National Laboratory
Pollutant Assessments Group

Health and Safety

Procedures Manual
Sect. 8 Rev. 2

Date 6/92

Page 22 of 50

SUBJECT: STANDARD OPERATING PROCEDURES

\subsubsection{Equipment Decontamination}

A decontamination site for the cleaning of equipment to background levels shall be prepared by spreading a durable, waterproof sheet or providing wash basins or a decontamination trough adjacent to the work site. Between sampling locations, drilling and sampling equipment will be placed on the sheet or in the basin or trough and decontaminated as stated in the site-specific work plan or health and safety plan. The sheet is to be arranged for secondary containments so that all wash water does not leak onto the ground. If there is contamination on the equipment that exceed DOE Order 5480.11 guidelines that cannot be removed, the equipment will be wrapped in plastic sheeting and secured until proper decontamination or disposal can be achieved.

These procedures apply to all equipment that comes in contact with samples such as drilling equipment, trowels, spades, spoons, straight bars, and pans, monitoring equipment, pens, clipboards, etc. task are

Equipment and supplies that may be listed in a site-specific plan necessary for this

- dust brooms

- 5-gal water jug(s) (filled with tap water)

- plastic tub or bucket

- stainless steel trays

- scrub brushes (plastic or fiber bristles)

- wire brush

- aluminum or stainless steel decontamination troughs and drying racks

- hot-water sprayer

- disposable wipes

- laboratory detergent

- plastic trash-can liners

- distilled water in wash bottle

- chemical reducing agents

NOTE: If equipment is only muddy and known to be contamination-free, wash it in tap water in plastic bucket or tub and then wash with soapy water in stainless steel bath. Rinse with tap water and dry with a disposable wipe. A different scrub brush will be used with each bath. Frisking for radiation contaminants will be performed as necessary.

Decontamination procedures, splash-protection equipment, and PPE as outlined in the site-specific work plan and health and safety plan will include consideration of natural and mechanically driven ventilation and/or the use of respirators. 
MARTIN MARIETTA

ENERGY SYSTEMS, INC.

Oak Ridge National Laboratory
Pollutant Assessments Group

Health and Safety

Procedures Manual
Sect. 8 Rev. 2

Date 6/92

Page 23 of 50

\section{SUBJECT: STANDARD OPERATING PROCEDURES}

All decontamination will be performed in a staging area. After cleaning, field equipment may be placed temporarily on stainless steel supports, polyethylene sheeting, or wrapped in aluminum foil to protect decontamination integrity. Care must be taken when choosing the site of the staging area to avoid fugitive dust, fuel oils, oils, gasoline, organic solvents, or any other potential source of contamination.

All drilling and/or sampling equipment, well screens and casing, backhoes, dredges, augers, continuous samplers, and other heavy equipment must be steam cleaned or washed with a high-pressure hot-water system before and after use as dictated in the site-specific work plan or health and safety plan.

\subsection{Sample Container Decontamination}

Sample bottles and shipping containers that have been filled will be tightly sealed, wiped clean of any possible contamination, and sealed in individual plastic bags at the sample site prior to shipping, as stated in the site-specific work plan. Transport containers such as ice chests shall be verified clean or decontaminated in the same manner as the sample bottles, and the sample identities shall be noted and cross-referenced with the chain-of-custody record. Transport containers shall be kept secure and affixed with at least two signed, tamper-proof custody seals to ensure courier safety and sample integrity.

\subsubsection{Waste Disposal}

Precise directives will be provided for all site-generated waste during the drilling and/or sampling as directed by the SPM in accordance with the prescribed site-specific plan.

Drill cuttings and/or excess sample materials shall be returned to the hole unless they are considered to be hazarcous, in which case storage in 55-gal drums at an approved storage facility will be necessary.

All disposable clothing, plastic sheeting and waste materials used during the operation must be double-bagged and removed to an approved off-site disposal facility as directed by the site-specific work plan. Decontamination and rinse solutions should be contained on-site for evaporation or be removed to an approved disposal facility. Reusable rubber clothing should be decontaminated, dried, and prepared for future use. (If abovebackground contamination of personal protective equipment is known or suspected, additional decontamination or disposal will involve on-site containerization for subsequent contamination verification for final disposition). Cloth items that are not suspected of containing hazardous contaminants should be bagged and removed from the site for final 
MARTIN MARIETTA

ENERGY SYSTEMS, INC.

Oak Ridge National Laboratory
Pollutant Assessments Group

Health and Safety

Procedures Manual
Sect. 8 Rev. 2

Date $6 / 92$

Page 24 of 50

\section{SUBJECT: STANDARD OPERATING PROCEDURES}

cleaning after first notifying the launderer of potential contamination and safety procedures to be followed. All monitoring equipment, wash tubs, pails, sample containers, etc., will be thoroughly washed, rinsed, and dried prior to removal from the site.

\subsubsection{Contamination Reduction Corridor}

All decontamination of personnel and equipment on the site shall be restricted to the existing or preauthorized decontamination site.

\subsubsection{Medical Emergency Decontamination}

The medical emergency decontamination procedures will be determined by the SSHO and detailed in the site-specific health and safety plan. Emergency decontamination will depend on the severity of the injury and the possibility of the spread of contamination. At least one prenotified medical facility that has emergency decontamination capability for patients with exposure to potentially hazardous contaminants will be detailed in the sitespecific health and safety plan. The names and phone numbers of local medical facilities, along with specific directions to their locations, will be included in the site-specific health and safety plan and will be relayed to all site personnel before any work is performed.

\subsection{CONTINGENCY PLANNING}

\section{Key Personnel}

ORNL representatives listed in Sect. 3 and in the site-specific health and safety plan shall be responsible for ensuring the implementation of this plan in the field.

\section{Emergency Evacuation Procedures}

In the event of an emergency requiring evacuation of the site, the ORNL field representatives shall notify all workers on-site. Evacuation will be by way of prescribed routes delineated in the site-specific health and safety plan.

\section{Nonroutine Occurrences}

In the event that nonroutine occurrences cause hazardous drilling and/or sampling conditions, work will be halted or delayed at the discretion of the ORNL field 
MARTIN MARIETTA

ENERGY SYSTEMS, INC.

Oak Ridge National Laboratory
Pollutant Assessments Group

Health and Safety

Procedures Manual
Sect. 8 Rev. 2

Date $6 / 92$

Page 25 of 50

SUBJECT: STANDARD OPERATING PROCEDURES

representatives. Any such halt or delay shall be recorded by an ORNL representative. Any person on an investigation project may cease operations if hazardous conditions are apparent or suspected.

If it is mutually agreeable to the ORNL representatives and the subcontractor personnel, a modified work schedule may be initiated.

\subsection{RECORDKEEPING}

Records of all safety- and health-related matters occurring during field operations shall be kept as part of the daily logs maintained by the ORNL representatives. These records shall include data collected by field instrumentation, health monitoring data, emergency plans and contacts, and records of any safety-related work delays or stoppages. A health and safety checklist form (Fig. 8.2) will be completed if safety requirements are suspected of being compromised.

\subsection{EMERGENCY PLANNING}

\subsubsection{Emergency Medical Services}

Prior to site investigation or activity on hazardous sites, nearby health facilities will be contacted and evaluated to determine their capabilities in relation to potential site-specific injuries and exposures of on-site project staff. Criteria such as emergency physician coverage, decontamination capabilities, and available medical specialists will be evaluated.

\section{On-Site First-Aid Preparations}

- An industrial first-aid kit will be provided at the work site and contents of the kit will be checked daily and restocked as necessary. Other equipment may include: surgical gloves, CPR masks, backboard and straps, ice packs, thermometer, activated charcoal, syrup of Ipecac, splints, and a cervical collar, dependant on a maxinnum off-site emergency medical response arrival time of 6 min or less.

- At least oue person qualified to perform first aid will be present on-site or be immediately available to the site at all times during work activity. This person will have earned a certificate in first aid and receive the required review training from the American Red Cross or will have received equivalent training. 
MARTIN MARIETTA

ENERGY SYSTEMS, INC.

Oak Ridge National Laboratory
Pollutant Assessments Group

Health and Safety

Procedures Manual
Sect. 8 Rev. 2

Date $6 / 92$

Page 26 of 50

SUBJECT: STANDARD OPERATING PROCEDURES

- Transportation to emergency treatment

- A vehicle will be available at all times for use in transporting personnel to the hospital (in the event an ambulance is unnecessary or unavailable).

- Transportation routes to area hospitals will be established prior to on-site activity.

\subsection{FIRST AID}

\subsubsection{Accident/Incident Assessment}

The first-aid provider will have a current first-aid certificate or other medical professional certificate.

The following steps will be used to assess what emergency problems exist and what actions are needed:

1. Remain calm. The first-aid provider will be able to assess the situation more effectively if you remember that psychological support is important.

2. Ask the victim if you can help. If the patient is unconscious, look for an emergency medical identification tag on the victim's wrist, ankle, or neck. Another alerting device could be a sticker on the windshield of the victim's car.

3. Utilize the ABCs of life support:

a. Airway open. Open and maintain the victim's airway.

b. Breathing restored. If the victim is not breathing, certified CPR personnel shall begin rescue breathing techniques immediately.

c. Circulation maintained. If there is no pulse, a CPR-certified person shall start external cardiac compression immediately.

4. Check for bleeding. If bleeding is found, apply direct pressure, elevate the injured limb only if it does not cause further pain or injury, and apply pressure on the blood-supplying artery. Only use a tourniquet for severe life-threatening hemorrhage as a last resort (i.e., when all other measures fail).

5. Look for signs of shock and broken bones.

6. Get professional help quickly. Know universal emergency numbers listed in the site-specific health and safety plan, such as $\mathbf{9 1 1}$ for most civilian communities and 117 for most military bases. Telephone appropriate authorities (rescue squad, ambulance, police, poison control center, or fire department) and describe the problem. Be sure to give your name and location, as well as the number of persons involved. Where phones are not available, radios should be used to summon appropriate help. Find out emergency number to use on radios; also use 911 or local firebox to notify appropriate personnel concerning the emergency.

7. Loosen any clothing that may restrict the victim's breathing or interfere with circulation. 
MARTIN MARIETTA

ENERGY SYSTEMS, INC.

Oak Ridge National Laboratory
Pollutant Assessments Group

Health and Safety

Procedures Manual
Sect. 8 Rev. 2

Date $6 / 92$

Page 27 of 50

\section{SUBJECT: STANDARD OPERATING PROCEDURES}

8. Never give an unconscious person anything orally.

9. Do not move injured person unless the situation is life threatening. Keep the victim still, quiet, and warm (except in cases of heat exhaustion, cold stress, and sunstroke). A victim with possible spinal damage or broken bones should not be moved until a cervical collar and spinal board have been properly applied by adequately trained personnel. Splints will be applied by trained personnel to support fractured bones.

\subsubsection{Vital Signs}

Once the situation is stabilized, the victirn's breathing and heart rate must be continually checked, and if possible, check the temperature, pupil response, and skin discoloration for signs and symptoms of shock. Pulmonary resuscitation techniques and cardiac compression shall only be performed by certified personnel when needed. Assign a bystander to contact emergency medical help immediately.

\subsubsection{Pulmonary Emergency}

Symptoms of breathing difficulties include shortness of breath, dizziness, chest pain, rapid pulse, bluish-purple skin color, dilated pupils, and unconsciousness. The SSHO shall be notified if any of these signs or symptoms are present.

\subsection{HEAT STRESS PREVENTION}

Because of the potential for an increase in ambient air temperatures and decreased body ventilation (because of protective outer wear) during site investigation activities, there exists an increase in the potential for injury, specifically heat casualties. Site personnel will be instructed in the identification of a heat stress victim, the first-aid treatment procedures for the victim, and the prevention of heat stress casualties.

\subsubsection{Identification and Treatment}

1. Heat rash

a. Signs and symptoms: Heat rash is caused by continuous exposure to heat and humid air and is aggravated by chafing clothes. It decreases heat tolerance as well as being a nuisance. 
MARTIN MARIETTA ENERGY SYSTEMS, INC.

Oak Ridge National Laboratory
Pollutant Assessments Group

Health and Safety

Procedures Manual
Sect. 8 Rev. 2

Date $6 / 92$

Page 28 of 50

\section{SUBJECT: STANDARD OPERATING PROCEDURES}

b. First aid: Good hygienic standards must be maintained by periodically changing clothing and daily showering as needed. Clothing should be permitted to dry during rest periods. Persons who notice skin problems should consult the SSHO or other medical personnel.

2. Heat cramps

a. Signs and symptoms: Heat cramps are caused by profuse perspiration with inadequate fluid intake and chemical replacement (especially salts) and will induce muscle spasms and pain in the extremities and abdomen, exhaustion, and periods of dizziness or faintness.

b. First aid: Move person to a cool, shaded location nearby. Give the affected person salted water ( 1 teaspoon per quart) or half-strength commercial electrolyte fluids. Use pressure massage on cramped muscle to ease pain. Apply warm, moist towels to the cramped muscles and the forehead. If the cramps persist or the condition of the person worsens, immediately provide for transport to a medical facility.

3. Heat exhaustion

a. Signs and symptoms: Usually begins with muscular weakness, dizziness, nausea, and a staggering gait. Vomiting is frequent. The bowels may move involuntarily. The victim will be very pale, have clammy skin, and may perspire profusely. The pulse is weak and fast; breathing is shallow. The victim may faint if not positioned in the shock position. This may pass, but sometimes it persists. Although heat exhaustion is generally not considered life threatening, death could occur.

b. First aid: Immediately remove the victim to the Decontamination Reduction Zone in a shady and cool area with good air circulation. Remove all protective outer wear. Assign someone to call for medical assistance. Treat the victim for shock. (Make victim lie down, raise feet 6 to 12 in., and maintain body temperature, but loosen all clothing.) If the victim is conscious, it may be helpful to give sips of cool water. Transport victim to a medical facility.

4. Heat Stroke

a. Signs and symptoms: This is the most serious of heat casualties because the body overheats excessively. Body temperatures are often between 107 to $110^{\circ} \mathrm{F}$. The victim will have a red face and will not be perspiring. First there is pain in the head, dizziness, nausea, oppression, and a dryness of the skin and mouth. Unconsciousness follows quickly, and death is imminent if exposure continues. The attack will usually occur suddenly. Heat stroke is always serious.

b. First aid: Immediately evacuate the victim to a cool and shady area. Assign someone to contact emergency medical help. Remove all protective outer wear and all heavy personal clothing. Lay the victim on his/her back with head and shoulders slightly elevated. It is imperative that the body 
MARTIN MARIETTA

ENERGY SYSTEMS, INC.

Oak Ridge National Laboratory
Pollutant Assessments Group

Health and Safety

Procedures Manual
Sect. 8 Rev. 2

Date $6 / 92$

Page 29 of 50

SUBJECT: STANDARD OPERATING PROCEDURES

temperature be lowered immediately. This can be accomplished by applying cold wet towels, ice bags, etc., to the head, under the armpits, behind the neck, and between the legs next to the groin. Sponge off the bare skin with cool water or rubbing alcohol, if available, or even place the person in a tub of cool water. The main objective is to cool without chilling. Give no stimulants. Transport the victim to a medical facility as soon as possible.

\subsubsection{Prevention of Heat Stress}

1. One of the major causes of heat casualties is the depletion of body fluids. Fluids should be maintained in the support zone. Personnel should replace water and salt loss from sweating. Salts can be replaced by either a $0.1 \%$ salt solution, more heavily salted foods, or commercial mixes such as Gatorade $\$$. Commercial mixes are advised for personnel on low-sc "um diets.

2. A work schedule will be established during warm weather so that the majority of the work day will be during the morning hours before ambient air temperature levels reach their highs.

3. A work/rest schedule will be implemented for personnel required to wear Levels A, B, or C protection (i.e., impervious outer garment). A sufficient period will be allowed for personnel to "cool down." This may require shifts of workers during operations in addition to the breaks provided by required air tank changes during Level $B$ and A operations. Maximum time between breaks at Level A, B, or $\mathrm{C}$ shall be $2 \mathrm{~h}$ regardless of temperature. At elevated temperatures, breaks should be lengthened with respect to rising ambient temperatures and stressful working conditions such as those for drilling or asphaltsurfacing crews.

4. Periodic breaks for "cool down" and liquid replenishment should also be scheduled while wearing any chemical-resistant outer wear, even in moderate ambient temperatures.

5. Wet-bulb globe test (WBGT) monitoring should be conducted on-site at all times, and work schedules should be based on WBGT readings.

\subsubsection{Heat Stress Monitoring}

For monitoring the body's recuperative ability to excess heat, one or more of the following techniques should be used as a screening mechanism. Monitoring of personnel wearing impervious clothing should commence when the ambient temperature is $70^{\circ} \mathrm{F}$ or above. Frequency of monitoring should increase as the ambient temperature increases or when slow recovery rates are indicated. When temperatures exceed $85^{\circ} \mathrm{F}$, workers should 
MARTIN MARIETTA

ENERGY SYSTEMS, INC.

Oak Ridge National Laboratory
Pollutant Assessments Group

Health and Safety

Procedures Manual
Sect. 8 Rev. 2

Date $6 / 92$

Page 30 of 50

SUBJECT: STANDARD OPERATING PROCEDURES

be monitored for heat stress after every work period. The following are important considerations:

1. Heart rate (HR) should be measured by the radial pulse for $30 \mathrm{~s}$ as early as possible in the resting period. In the beginning of the rest period, the HR should not exceed 110 beats/min. If the HR is higher, the next work period should be shortened by $10 \mathrm{~min}$ (or 33\%), while the length of the rest period stays the same. If the pulse rate is 100 beats per minute at the beginning of the next rest period, the following work cycle should be shortened by $33 \%$.

2. As early as possible in the resting period, body temperature should be measured orally with a clinical thermometer. Oral temperature (DT) at the beginning of the rest period should not exceed $99^{\circ} \mathrm{F}$. If it does, the next work period should be shortened by $10 \mathrm{~min}$ (or $33 \%$ ), while the length of the rest period stays the same; however, if the OT exceeds $99.7^{\circ} \mathrm{F}$ at the beginning of the next period, WBGT monitoring should be conducted and the following work cycle should be further shortened by $33 \%$. OT should be measured again at the end of the rest period to make sure that it has dropped below $99^{\circ} \mathrm{F}$.

3. Good hygienic standards must be maintained by frequent changes of clothing and daily showering. During rest periods, clothing should be permitted to dry.

Persons who notice skin problems should immediately consult medical personnel.

4. Use of cooling units, vests, etc., is highly recommended.

\subsection{COLD STRESS PREVENTION}

Cold weather often causes problems for personnel working outside. There are several types of cold weather injuries that can occur, even at temperatures above freezing. As temperatures drop below freezing, the potential for these injuries increases dramatically, as does the potential for equipment failure. Because of the considerable danger to personnei, outdoor work should be suspended if the ambient temperature drops below $0^{\circ} \mathrm{F}\left(-18^{\circ} \mathrm{C}\right)$ or if the wind chill factor drops below $-29^{\circ} \mathrm{F}\left(-34^{\circ} \mathrm{C}\right)$. This level represents a guideline that should be used as an action level unless the SPM and SSHO determine that warming breaks and protective clothing are adequate to allow operations to continue.

Snow and ice add additional risks to personnel and operations: reduced visibility, increased potential for falling injuries, reduced on-site mobility, equipment failure, and the increase in time required to access the site (or off-site support services).

The SSHO will establish site-specific safety and operating protocols and ensure that all on-site personnel are aware of the recognition and treatment of cold weather injuries. 


\subsubsection{Cold Injuries}

Local cold injuries are those that affect specific areas of the body (e.g., fingers, ears, and toes) and include the more commonly recognized cold weather injuries described in the following.

1. Chilblains is a condition that can result from prolonged exposure of bare skin to temperatures of $60^{\circ} \mathrm{F}$ or below. This condition generally occurs in the extremities and is a chronic injury of the skin and peripheral capillary circulation. Covering and protecting the skin from prolonged exposure to the cold is the best method of preventing and treating chilblains.

2. Frostbite is the freezing of some part of the body as a result of exposure to very low temperatures. Frostbite can affect hands, feet, ears, and exposed parts of the face. It occurs when ice crystals form in the fluid in cells of the skin and tissue. As long as blood circulation remains good, frostbite will not occur. Frostbite is a constant hazard in subzero weather, especially where there are strong winds. There are three stages of frostbite. Classification depends on the amount of tissue damage. Severity can range from incipient frostbite (frostnip), which affects the skin, to superficial frostbite, which involves the skin and the tissues immediately beneath it, to deep frostbite, a much more serious injury with damage that may affect deeper tissues and even bones.

a. Symptoms: Symptoms for each of the three stages of frostbite include: Frostnip. Skin first turns red, later becomes pale or waxy white. There may be tingling, stinging, or aching, uncomfortable sensation of coldness, followed by numbness, or the condition may go unnoticed.

Superficial Frostbite. Skin is white or gray-white and waxy in appearance. Skin is firm to touch, does not move easily. Tissue beneath the skin is soft and resilient. There is a lack of sensation in the area.

Deep Frostbite. Tissues are pale, cold, and solid. Usually affects hands and feet. Blisters and swelling may occur.

b. Emergency treatment of frostbite.

Frostnip is easily reversed in the field by the application of body heat. Apply body heat before the affected area becomes numb. Thaw frozen spots immediately. Do not rub affected areas. If frostnip affects the fingers and hands, place them against warm skin on the chest or under the armpits. To warm the face, hold a mitten or scarf over the lower part of the face and have the person breathe into it.

Superficial frostbite usually responds to the application of body heat. If it does not or if it resembles the early stages of deep frostbite. Treat as if it were deep frostbite. 
MARTIN MARIETTA ENERGY SYSTEMS, INC.

Oak Ridge National Laboratory
Pollutant Assessments Group

Health and Safety

Procedures Manual
Sect. 8 Rev. 2

Date $6 / 92$

Page 32 of 50

\section{SUBJECT: STANDARD OPERATING PROCEDURES}

Deep frostbite. If possible, remove person to a heated shelter to avoid further frostbite. Remove all constricting items (boots, gloves, and socks) from area of injury if it can be done without danger of further frostbite. RAPID REWARMING WILL MINIMIZE TISSUE LOSS. Warm extremities in a carefully controlled warm water bath $\left(104\right.$ to $\left.106^{\circ} \mathrm{F}\right)$ until tips of the fingers or toes turn pink and feeling is restored. Too rapid rewarming using bath water temperatures in excess of $106^{\circ} \mathrm{F}$ will cause an instant circulation of the cold blood to the core of the body, which could be fatal. If a water bath is not available, use ALTERNATIVE METHODS:

- Apply wet packs $\left(100\right.$ to $\left.112^{\circ} \mathrm{F}\right)$ to the person's body.

- Gently wrap frostbitten area in blankets or other warm material.

- DO NOT attempt to thaw by exercising the affected parts or heating them in front of an open fire, heat lamps, radiator, or a stove-the person may have lost sensation in the parts and may receive a heat injury as a result.

- DO NOT use snow to thaw frostbite.

- DO NOT rub, massage or use pressure on the affected areas.

- Observe to determine if CPR is necessary.

- Continue care:

- Keep frostbitten parts elevated if possible.

- Give victim warm drinks such as tea, coffee, or soup.

- DO NOT GIVE ALCOHOLIC BEVERAGES.

- Have victim exercise fingers or toes as soon as they are warmed.

- DO NOT allow a person with frostbitten feet to walk. It may cause additional damage.

c. Medical treatment of frostbite.

Frostnip usually does not require medical care.

Superficial frostbite. Blisters may require medical care. Deep frostbite. EARLY MEDICAL TREATMENT IS URGENT! Get the victim to medical care at once.

d. Prevention of frostbite. It is far easier to prevent or to stop frostbite in earlier stages than to thaw and take care of badly frozen flesh.

- Personnel should wear enough clothing to protect themselves against cold and wind, including gloves and boots and rain gear when necessary. Chemical-resistant coveralls and gloves can provide additional protection against cold, wet, and windy conditions.

- Pull a scarf or jacket flap over the lower part of the face or a hood tightly around the face.

- Exercise face, fingers and toes from time to time to keep them warm and to detect any areas that may have become numb.

- Crew members should watch each other closely for signs of frostbite, especially on the face. 
MARTIN MARIETTA

ENERGY SYSTEMS, INC.

Oak Ridge National Laboratory
Pollutant Assessments Group

Health and Safety

Procedures Manual
Sect. 8 Rev. 2

Date 6/92

Page 33 of 50

\section{SUBJECT: STANDARD OPERATING PROCEDURES}

3. Immersion foot (formerly called trench foot) is a cold injury resulting from prolonged exposure to temperatures near freezing, especially when standing or walking in wet or swampy ground.

a. Symptoms: In the early stages the feet and toes are pale, feet are cold, numb, and stiff. Walking is difficult. If preventive action is not taken, feet will swell and ache. In extreme cases, irreversible damage to the tissues of the foot or leg ma; result.

b. Emergency treatment of immersion foot: Feet should be handled very gently. Do not rub or massage. If necessary, clean feet carefully with soap and water, then dry and elevate them, and expose them to warm air or wrap with warm towels.

c. Prevention of immersion foot. Because early stages of immersion foot are not painful, personnel must constantly be alert to prevent this condition.

- Check feet often when working in a wet, cold environment.

- Keep feet dry by wearing waterproof footgear and avoid standing in wet areas.

- Because perspiration or decontamination fluids trapped inside waterproof boots or heavy footgear can contribute to immersion foot symptoms, personnel should change their socks frequently and change boots if necessary.

- Dry and rewarm feet as soon as possible if they get wet. Use foot powder and put on dry socks.

- Never wear tight boots; move ankles and wiggle toes frequently.

\subsubsection{Systemic Cold Injuries}

Systemic injuries are those that affect the entire body system. Severe general body cooling is known as systemic hypothermia and can occur at temperatures well above freezing. Hypothermia is the progressive lowering of body temperature accompanied by rapid, progressive mental and physical collapse. Subnormal temperature within the central body can be fatal.

Hypothermia is caused by exposure to cold and is aggravated by moisture, cold winds, fatigue, hunger, and inadequate clothing or shelter. Excessive perspiration from strenuous exercise followed by too rapid cooling can lead to hypothermia.

Hypothermia usually occurs between the temperatures of $30-49^{\circ} \mathrm{F}$. Crew members should be alert for symptoms of hypothermia, especially when temperatures are dropping rapidly or when work is performed in rain, snow, or ice. 


\section{SUBJECT: STANDARD OPERATING PROCEDURES}

Hypothermia may occur on land or following submersion in even moderately cold water, $65^{\circ} \mathrm{F}$ or below. Death in cold water may seem to be from drowning but it is usually the result of hypothermia.

1. Symptoms. In the early stages of hypothermia, the body begins to lose heat faster than it can produce it and makes efforts to stay warm by shivering. When the body can no longer generate heat fast enough to overcome heat loss and the energy reserves of the body are becoming exhausted, a second stage begins: the body temperature begins to drop. This affects the ability of the brain to make judgments and also results in loss of muscular control. As the body temperature drops, hypothermia symptoms become increasingiy severe.

Symptoms of hypothermia

Person is conscious, alert. May have shivering that becomes unconirollable as core temperature drops to $95^{\circ} \mathrm{F}$. Respirations increase at first.

Person is conscious but disoriented, apathetic. Shivering present but diminishes as temperature drops. Below $92^{\circ} \mathrm{F}$ respiratory rate gradually diminishes, pupils begin to dilate.

Person is semiconscious. Shivering present but diminishes as temperature drops. Below $92 \%$ respiratory rate gradually diminishes, pupils begin to dilute.

Unconscious, diminished respirations.
Approximate

core

temperatures

Above $95^{\circ} \mathrm{F}$

$95-90^{\circ} \mathrm{F}$

$90-86^{\circ} \mathrm{F}$

Below $86^{\circ} \mathrm{F}$

2. Emergency treatment of hypothermia. In very mild cases of hypothermia, dry clothing and shelter may be all that is needed.

- Move victim to shelter and warmth as rapidly as possible.

- Gently remove all wet clothing and replace it with dry clothing.

- Give the person something warm to drink. Do not give alcoholic beverages.

ALL OTHER CASES SHOULD BE CONSIDERED MEDICAL EMERGENCIES.

PROVIDE EXTERNAL HEAT ANY WAY POSSIBLE! 
MARTIN MARIETTA

ENERGY SYSTEMS, INC.

Oak Ridge National Laboratory
Pollutant Assessments Group

Health and Safety

Procedures Manual
Sect. 8 Rev. 2

Date $6 / 92$

Page 35 of 50

\section{SUBJECT: STANDARD OPERATING PROCEDURES}

A WARM BATH with the water kept between 105 and $110^{\circ} \mathrm{F}$ is the most effective way of warming a victim of hypothermia.

If it is not possible to give the person a warm bath, use an ALTERNATIVE METHOD:

- Wrap warm moist towels (or other fabric) around the victim's head, neck, sides, and groin. As the packs cool, rewarm them by adding warm water (about $105^{\circ} \mathrm{F}$ ). Water should be warm, not hot.

- DO NOT wrap a hypothermia victim in a blanket without an auxiliary source of heat unless it is to protect against any further heat liss before treatment can begin.

- DO NOT leave the person in a sleeping bag without extra heat while going for help unless there is no other alternative.

- Continue treatment:

- Give warm liquids and nourishing food if the person is conscious.

- Check the person for symptoms of frostbite, and if necessary, give treatment for frostbite.

- Handle the patient gently and do not allow him to walk. Exertion can circulate cold stagnant blood from extremities to the central body and cause "after-drop," in which the patient's core temperature may drop below the level that will sustain life. (Alcohol also contributes to after-drop.)

3. Medical care for hypothermia. HYPOTHERMIA IS A SEVERE EMERGENCY. GET MEDICAL TREATMENT AS SOON AS POSSIBLE. Even persons with mild hypothermia should see a doctor.

4. Prevention of hypothermia. Personnel should not go into the field in cold weather without wearing adequate clothing and taking a complete change of warm clothes and one or two pairs of extra socks as described in preventing frostbite (Sect. 8.6.4.1).

\subsection{FIRST-AID EQUIPMENT}

In view of the causes, results, and appropriate treatment of cold weather injuries discussed in the preceding, the following items should be included as safety equipment during cold weather operations.

- Warming booths or vehicles in close proximity to all personnel

- Extra clothing for all personnel, including insulating liners for hard hats

- Blankets

- High-energy food and drinking water supply

- Lifelines 


\subsection{ADVERSE WEATHER OPERATIONS}

Adverse weather conditions can soverely affect operations. The SPM and SSHO will plan work schedules and project tasks accordingly.

\subsubsection{Preliminary Assessment}

When personnel are to be working outdoors in cold weather, assess the local weather conditions through the news media (radio, television, newspapers) to determine the amount of preparation necessary. Consider such circumstances as

- the typical wind and weather conditions for the period in which sampling will be performed;

- the areas in which work is sheltered or open to the wind;

- proximal facilities for periodic breaks, acquisition of warm or cold food and beverages, and a source of drinking water;

- the length of time that crew members will have to work outdoors in the cold; and

- use of a vehicle for a warming area or heaters in a closed room can limit adequate ventilation and cause carbon monoxide poisoning.

\subsection{Scheduling}

- Schedule work in the least severe weather.

- Plan to rotate crew members to keep extreme exposure short.

Very close attention must be paid to the effects of cold weather on field equipment. Many types of batteries can be severely affected by cold, resulting in disabled air-monitoring equipment, sampling pumps, and vehicles. A supply of fresh batteries, sufficient number of charging units, and a set of automotive jumper cables should be maintained on-site.

The electronics in many field instruments such as PIDs, CGIs, and oxygen meters can also be adversely affected by the cold. Sections $13,14,15$, and 16 must be consulted for operating ranges.

If at all possible, monitoring well sampling should not be scheduled during cold weather. These tasks generally require the use of (relatively delicate) pumps; long, uninsulated stretches of tubing; and significant quantities of decontamination solutions. Unless considerable effort is expended to prevent pumps, hoses, decontamination solutions, and sample containers from freezing, attempts to sample monitoring wells in 
MARTIN MARIETTA

ENERGY SYSTEMS, INC.

Oak Ridge National Laboratory
Pollutant Assessments Group

Health and Safety

Procedures Manual
Sect. 8 Rev. 2

Date $6 / 92$

Page 37 of 50

SUBJECT: STANDARD OPERATING PROCEDURES

cold weather may be counter-productive. Portable shelters should be considered if cold weather sampling is necessary. Additional time must be allotted in the morning to check-out and warm-up field equipment. Additional time must also be allotted for the end of the day to drain hoses and pumps, pack and secure equipment, and plan the next day's activities based on up-to-date weather forecasts. Allow sufficient time for frequent warming breaks.

\subsubsection{Lightning Storms}

Site investigation work during lightning storms will be terminated at the discretion of the SSHO and/or SPM, especially when drill rig masts are in the upright position. Estimation of lightning storm proximity and movement can be calculated using a correlation between the sighting of a lightning bolt (the speed of light) and the number of seconds elapsed before the thunder is heard (the speed of sound, $1100 \mathrm{ft} / \mathrm{s}$ ). The elapsed time in seconds is approximately equal to the distance in miles of the lightning storms location. Site personnel should evacuate the work area if the lightning is within 3 miles = $15 \mathrm{~s}$. This calculation is only effective when a storm is located in an individual quadrant near the work area (vs in several surrounding quadrants). If site personnel are not confident in the calculation of distance, rate of direction or travel, or if the lightning storm occurs in numerous directions around the site, work should cease.

\subsection{Tornadoes}

A black funnel cloud or tornado visually sighted or reported through radio monitoring as occurring within 10-mile of the work area will be cause for terminating all site activities. Appropriate evacuation procedures will be directed by the SSHO or SPM in accordance with local protocols.

\subsubsection{Site Access Maintenance}

Mud, snow, and ice could make travel on site access roads impossible or treacherous, at best. Personnel should not be allowed to work on-site if conditions severely hamper the arrival or departure of emergency vehicles. An otherwise minor injury could result in a major medical emergency if the route to off-site medical facilities is blocked by mud, snow, ice, etc. 
MARTIN MARIETTA

ENERGY SYSTEMS, INC.

Oak Ridge National Laboratory
Pollutant Assessments Group

Health and Safety

Procedures Manual
Sect. 8 Rev. 2

Date 6/92

Page 38 of 50

SUBJECT: STANDARD OPERATING PROCEDURES

If conditions warrant, the following provisions should be made:

1. Snow removal/plowing or gravel application services for site access roads should be secured.

2. A dependable four-wheel drive vehicle should be available immediately on-site to transport injured persons to off-site medical facilities.

3. Some type of shelter, blankets, food supply, and water should be provided on-site in the event a sudden storm requires personnel to remain on-site longer than anticipated.

4. A means to contact air ambulance service shouid be planned in advance.

The SSHO must decide when weather conditions make site access and working conditions unsafe and must ensure that work is discontinued until conditions improve.

\subsubsection{Equipment and Supplies}

Obtain equipment and supplies that will belp prevent environmental stress and that will help in the treatment of injuries or other medical emergencies.

If the site is very windy, provide means of shielding workers from the wind.

If working at a distance from stores, carry extra food and water because hunger and dehydration contribute to cold stress. Secure a sanitary means of providing hot food and beverages.

Provide emergency communication equipment when possible for use between ground crews working in adverse weather conditions and remote locations.

\subsection{WOUND CARE}

Wash hands thoroughly with soap and water and change into clean clothing and latex gloves before decontaminating the wound and administering first aid, otherwise minor cuts and scrapes can become contaminated and infected. Using the following wound-management techniques, personnel certified in first aid can prevent or reduce the possibility of infection. Prepare a clean, uncluttered place to put articles required to provide care. Do not to touch the wound unnecessarily or breathe or cough on/over the wound. Keep the wound and all first-aid materials as clean as possible. When opening packages of sterile pads or dressings, handle only the edges; do not touch the area that comes in contact with the wound. All injuries, even if considered minor will require 
MARTIN MARIETTA

ENERGY SYSTEMS, INC.

Oak Ridge National Laboratory
Pollutant Assessments Group

Health and Safety

Procedures Manual
Sect. 8 Rev. 2

Date $6 / 92$

Page 39 of 50

SUBJECT: STANDARD OPERATING PROCEDURES

medical attention pertinent to the degree of the injury and will be reported to the SPM and SSHO for documentation.

\subsubsection{Surface Wounds}

Cleanse the wound and the surrounding area gently with mild soap and water and rinse. Blot the wound dry with a sterile pad or clean dressing. Treat the wound to protect against contamination, and cover it to soak up fluids (blood and lymph) and to prevent further contamination. Handle only the edges of sterile pads of dressings.

The following bandage types may be used:

1. Adhesive pads for large wounds, cuts, or scrapes. This is a convenient, one-step bandage to cushion and protect.

2. Sterile pads for cuts, scrapes, or other minor wounds.

3. Nonstick sterile pads for bleeding and draining wounds, burns, and infections. These will not stick to the wound or disrupt the healing process.

4. Rolled gauze for securing sterile pads. This is especially good for joints and hard-to-bandage wounds.

5. First-aid tape to secure bandages and help keep out dirt and germs.

\subsubsection{Deep Wounds and Serious Burns}

Perform personal decontamination and don sterile latex gloves if possible. Briefly cleanse and immediately apply direct pressure. If bleeding occurs, a dressing and secure bandage should be applied using direct pressure. The patient should be treated for shock. One must be alert for signs of infection such as a hot, painful reddening around the wound, swelling, chills, and/or fever. Consult a physician immediately. A means to contact a physician by way of radio or remote mobile phone should be planned in advance.

\subsection{BANDAGING}

Emergency bandages will be found in the first-aid kit or can be devised from clean handkerchiefs, sheets, belts, socks, or coveralls. Bandages should be snug but not tight enough to interfere with circulation. Always leave the victim's fingertips or toes exposed when a splint or bandage is applied to the arms or legs. Loosen the bandage if swelling, discoloration, or a cold, numb, or tingling sensation occurs in the fingers or toes. Never apply a bandage to a neck injury so tight as to restrict the circulation of blood to the brain. 
MARTIN MARIETTA

ENERGY SYSTEMS, INC.

Oak Ridge National Laboratory
Pollutant Assessments Group

Health and Safety

Procedures Manual
Sect. 8 Rev. 2

Date $6 / 92$

Page 40 of 50

SUBJECT: STANDARD OPERATING PROCEDURES

\subsection{CONTINGENCY PLANNING}

Prior to commencement of on-site activities, field personnel will review safety considerations with the SSHO and SPM. The SSHO is responsible for adherence to the designated safety precautions and assumes the role of on-site coordinator in an emergency response situation.

All on-site personnel will be familiarized with both the primary and, if available, secondary route to the nearest hospital (which will be detailed clearly on the health and safety plan or local map) as well as the location of the nearest working telephone or radio- communication device. Each site worker will receive a list of emergency phone numbers in the site-specific health and safety plan.

The local hospital and emergency response team will be advised in advance by the SSHO of the work to be performed. The hospital will also be briefed on the availability of personal health data and medical support given to the victim. Among site personnel, at least two persons should be trained in CPR and first aid.

Emergency communication will be required to ensure positive preplanned notification of emergency authorities in the event of episodes requiring initiation of contingency plans.

- Communication will be coordinated with local agencies, fire department, police, ambulance, and hospital emergency room.

- Two-way radio communication may need to be established in the field, and a site alarm capable of warning site personnel and summoning assistance will be maintained.

- Emergency evacuation for residents of nearby homes is an unlikely event, but at most facilities a person will be designated to be responsible for implementing the contingency plan; otherwise, the SPM will notify the local emergency and law enforcement agencies. The person will be made aware of the total number of households within a $2000-\mathrm{ft}$ radius. The health and safety plan will provide the emergency contacts that will be required, and an additional table will provide a list of residences and identifiable operations in the area in the event that evacuation is judged to be a possibility for a particular site.

- Prior to any activity, personnel will investigate all possible routes of evacuation.

\subsection{POTENTIAL HAZARDS}

The most common hazards associated with hazardous waste site investigation include:

(1) accidents, (2) contact or ingestion of hazardous materials, (3) heat stress,

(4) explosion, and (5) fire. 
MARTIN MARIETTA

ENERGY SYSTEMS, INC.

Oak Ridge National Laboratory
Pollutant Assessments Group

Health and Safety

Procedures Manual
Sect. 8 Rev. 2

Date 6/92

Page 41 of 50

SUBJECT: STANDARD OPERATING PROCEDURES

\subsubsection{Accidents}

Accidents must be handled on a case-by-case basis. Minor cuts, bruises, muscle pulls, etc., will still allow the injured person to undergo reasonably normal decontamination procedures prior to receiving direct first aid. More-serious injuries may not permit complete decontamination procedures to be undertaken, particularly if the nature of the injury is such that the victim should not be moved. The nature and degree of surface contamination at a site is generally low enough that emergency vehicles can reach the victim on-site without undue hazard; however, in the event that access on-site is limited, accident victims may be transported to a point accessible by an ambulance by appropriately trained ORNL personnel. This includes confirmation that spinal injury requiring a cervical collar and spinal board is not required. All injuries and accidents, no matter how minor will be reported to the SSHO and SPM.

\subsubsection{Contact and/or Ingestion of Hazardous Materials}

Properly prescribed and maintained protective clothing and adherence to established safety procedures are designed to minimize this hazard; however, contact or ingestion of materials may still occur. In this situation, the SSHO or SPM will assign a bystander or consult medical help immediately. One possibility for exposure is the puncture of a buried drum of liquid during drilling operations that might cause the drum contents to contact personnel.

Standard first-aid procedures should be followed. The decontamination station will have an adequate supply of water, which may be useful in some circumstances, particularly to flush contaminants off any exposed areas of skin. Eye-wash bottles will also be maintained at the site in case of emergencies. In cases of ingestion or other than minor contact with known substances, the local Poison Control Center and hospital to which the victim is to be taken should be contacted; and the victim should be taken there immediately for further treatment and observation.

\subsubsection{Perconal Protective Clothing}

Types of materials used in protective clothing should be considered when designating the personnel protection equipment for a specific site. Some materials currently used are

1. Butyl rubber. Resists degradation by many contaminants except halogenated hydrocarbons and petroleum compounds, a deficiency common to most protective 
MARTIN MARIETTA

ENERGY SYSTEMS, INC.

Oak Ridge National Laboratory
Pollutant Assessments Group

Health and Safety

Procedures Manual
Sect. 8 Rev. 2

Date $6 / 92$

Page 42 of 50

SUBJECT: STANDARD OPERATING PROCEDURES

materials. Especially resistant to permeation by toxic vapors and gases. (Expensive materials are used in boots, gloves, splash suits, aprons, and fully encapsulating suits.)

2. Chloropel $\$$ (E. I. duPont de Nemours and Company). Also referred to as chlorinated polyethylene (CPE). Used in splash suits and fully encapsulating suits. No data on permeability is currently available. Considered to be a good all-around protective material.

3. Cloth. Provides skin protection; to be used only in certified clean areas.

4. Leather. Resists abrasions and avulsions to skin; can only be used in certified clean areas.

5. Natural rubber. Resists degradation by alcohols and caustics. Used in boots and gloves.

6. Neoprene. Resists degradation by caustics, acids, and alcohols. Used in boots, gloves, and respirator facepieces and breathing hoses. Commonly available and inexpensive.

7. Nitrile. Also referred to as Buna-N, milled nitrile, nitrile latex, NBR, and acrylonitrile; resists degradation by petroleum compounds, alcohols, acids, and caustics; used in boots and gloves; commonly available and inexpensive.

8. Nomex (E. I. duPont de Nemours and Company). Product of Dupont. Aromatic polyamide fiber. Noncombustible and flame resistant up to $200^{\circ} \mathrm{C}$, thus providing good thermal protection. Very durable and acid resistant. Used in fire fighters' turnout gear and some fully encapsulating suits.

9. Polyethylene. Used as a coating on polyolefin material, such as Tyvek, increasing resistance to acids, bases, and salts.

10. Polyvinyl alcohol (PVA). Resists degradation and permeation by aromatic and chlorinated hydrocarbons and petroleum compounds. Major drawback is its solubility in water. Used in gloves.

11. Polyvinyl chloride (PVC). Resists degradation by acids and caustics. Used in boots, gloves, aprons, splash suits, and fully encapsulating suits.

12. Saranex (Dow Chemical Company). Made of Saran, a Dow Chemical product. Coated on Tyvek (Tyvek Corporation). Very good for general purpose disposable material.

13. Viton (E. I. duPont de Nemours and Company). Product of Dupont. Fluoroelastomer similar to Teflon (E. I. duPont de Nemours and Company). Excellent resistance to degradation and permeation by aromatic and chlorinated hydrocarbons and petroleum compounds. Very resistant to oxidizers. (Extremely expensive material used in gloves and fully encapsulating suits.) 
MARTIN MARIETTA

ENERGY SYSTEMS, INC.

Oak Ridge National Laboratory
Pollutant Assessments Group

Health and Safety

Procedures Manual
Sect. 8 Rev. 2

Date $6 / 92$

Page 43 of 50

\section{SUBJECT: STANDARD OPERATING PROCEDURES}

\subsubsection{Explosion Hazards}

The drilling crew should be keenly aware of combustible gas meter readings and alarms and should withdraw at any indication of imminently hazardous conditions (greater than $20 \%$ LEL). The detection of such conditions shall be reported to local agencies for potential execution of the evacuation plan should the situation warrant such response and should be documented in the site logbook. All extremely dangerous incidents will immediately be reported to the SPM and SSHO and other site personnel.

\subsubsection{Fire}

The combustible gas meter also warns of imminent fire hazards at borings. The greatest fire hazards at investigation sites should be recognized as generator refueling, handling of fluids (e.g., methanol and acetone) used for certain decontamination procedures, and drilling into underground gas lines or combustible underground plumes. Smoking and open flames are prohibited on-site. Carbon dioxide fire extinguishers will be kept within $100 \mathrm{ft}$ of all motorized equipment and at the decontamination area. The SSHO and/or fire department, previously informed of site activities, will be called as needed.

\subsection{EVACUATION PROCEDURES}

Evacuation responses will occur at three levels: (1) withdrawal from immediate work area to the support and decontamination zone $(50+\mathrm{ft}$ upwind and if possible uphill), (2) site evacuation, and (3) evacuation of surrounding area. Anticipated conditions that might require these responses are described below:

1. Withdrawal upwind ( $50 \mathrm{ft}$ or more)

- Sensing that ambient air conditions contain greater contaminant concentrations than guidelines allow for the type of respiratory protection being worn. The work party may return after donning greater respiratory protection and/or assessing the situation as transient and past.

- Breach in protective clothing or minor accident. The party may return when tear or other malfunction is repaired and first aid or decontamination has been administered.

2. Site evacuation

- Respirator malfunctions and must be replaced.

- Sensing that ambient air conditions contain explosive and persistent levels of combustible gas or excessive levels of toxic gases.

- Imminent explosion or fire. 
MARTIN MARIETTA

ENERGY SYSTEMS, INC.

Oak Ridge National Laboratory
Pollutant Assessments Group

Health and Safety

Procedures Manual
Sect. 8 Rev. 2

Date $6 / 92$

Page 44 of 50

SUBJECT: STANDARD OPERATING PROCEDURES

3. Surrounding area evacuation

Persistent, unsuppressable release of toxic or explosive vapors from test pits or borings (possible pressure release from punctured drum). Air quality should be monitored at several distances downwind to assess danger to surrounding area before initiating this response.

\subsubsection{Withdrawal Upwind}

The work party will continually note general wind directions while on-site. On noting the conditions warranting movement away from the work site, the crew will move upwind a distance of approximately $50 \mathrm{ft}$ or further as indicated by the site monitoring instruments. Donning personnel protective equipment specific to the hazardous conditions, the SSHO or an adequately trained SSHO backup will return to the work site to determine if the condition noted was transient or persistent. If persistent, then an alarm as specified in the site health and safety plan will be used to notify on-site personnel of the situation and the need to leave the site or initiate the necessary upgrade in protection. An attempt should be made to decrease emissions, but only after increased respiratory and personal protection is donned. The SPM and client will be notified of conditions. When access to the site is restricted and escape may thus be hindered, the crew may be instructed to evacuate the site rather than move upwind, especially if withdrawal upwind moves the crew away from escape routes.

\subsection{Site Evacuation}

On determination of conditions warranting site evacuation, the work party will proceed upwind of the work site and notify the SSHO, SPM, and the field office of site conditions. If the decontamination area is upwind and is a safe distance from the work site, the crew will pass quickly through decontamination to remove potentially contaminated outer clothing. If the hazard is toxic gas, Level A or B respiratory protection will be donned. The crew will proceed to a designated safe meeting place to assess the situation. There, the respiratory protection may be removed (if instrumentation indicates an acceptable condition). As more facts are determined from the field crew, they will be relayed to the appropriate agencies. The advisability and type of further response action will be coordinated and carried out by the SSHO. 
MARTIN MARIETTA

ENERGY SYSTEMS, INC.

Oak Ridge National Laboratory
Pollutant Assessments Group

Health and Safety

Procedures Manual
Sect. 8 Rev. 2

Date $6 / 92$

Page 45 of 50

SUBJECT: STANDARD OPERATING PROCEDURES

\subsubsection{Evacuation of Surrounding Area}

When the SSHO determines that conditions warrant evacuation of downwind residences and commercial operations, the local emergency response agencies will be notified and assistance requested. Designated on-site personnel will initiate evacuation of the immediate off-site area without delay.

\subsubsection{Exclusion Zone Reentry}

In all situations, when an on-site emergency results in evacuation of the exclusion zone, personnel will not reenter until:

- conditions resulting in the emergency have been corrected,

- hazards have been reassessed,

- the health and safety plan has been reviewed, and

- site personnel have been briefed on any changes in the health and safety plan.

\subsubsection{Emergency Reporting Requirements}

All incidents (accidents, illnesses, injuries, and/or exposures to hazardous substances), regardless of how minor, will be reported and recorded on an Accident and/or Incident Report Form by the SSHO. As soon as possible following an accident or injury, the SSHO will report the occurrence to the SPM. The CPM will be notified by the SSHO or SPM so that a report can be filed with the ORNL physician.

At a minimum, a written report will be prepared for the project file that will include the following information:

- Date, time, and place of occurrence

- Person(s) involved

- Type of incident

- Description of incident and action taken

- Recommendations for prevention of similar occurrences

The report will be signed and dated by the preparer.

\subsection{Ordnance Materials}

Although the presence of active ordnance is considered to have a relatively low probability, there can always be a possibility of encountering active ordnance near 
MARTIN MARIETTA

ENERGY SYSTEMS, INC.

Oak Ridge National Laboratory
Pollutant Assessments Group

Health and Safety

Procedures Manual
Sect. 8 Rev. 2

Date $6 / 92$

Page 46 of 50

SUBJECT: STANDARD OPERATING PROCEDURES

munitions training areas. The following procedures will be followed during site investigations if ordnance materials are known or suspected to create a safety hazard:

- Cease all site activities directly associated with the area of concern.

- Notify the SSHO, who will secure the area and send someone to contact base security and fire department personnel.

- Trained specialists will in turn be notified by base security and will be made aware of all suspected ordnance locations. These trained specialists will instruct the personnel involved in the field investigations regarding the procedures to be followed in ordnance safety and will investigate the report.

- Metal detector or electromagnetic surveys will be performed prior to drilling or sampling activities to identify any potential ordnance.

\subsection{Ilumination Recommendations}

Proper lighting of work areas should conform to the levels listed in Table 8.2.

\section{REFERENCES}

American Conference of Governmental Industrial Hygienists. 1990-1991. Threshold

Limit Values for Chemical Substances and Physical Agents and Biological Exposure

Indices, 1990-1991. ACGIH, Cincinnati.

Code of Federal Regulations-29, Pt. 1900-1910, 1990.

Code of Federal Regulations-29, Pt. 1926, 1910, 1990. OSHA 2207/893.

Code of Federal Regulations-30, Pt. 1-199, 1988.

Code of Federal Regulations-40, Pt. 150-189, 1990.

Condensed Chemical Dictionary-11th Ed. Revised by N. Irving Sax, Richard

J. Lewis, Sr.

DOE. 1985. Comprehensive Environmental Response, Compensation, and Liability

Act Program. DOE Order 5480.14. U.S. Department of Energy, Washington, D.C.

EPA 1981. Health and safety requirements for employees engaged in field activities. Environmental Protection Agency Order 1440.1. U.S. Environmental Protection Agency, July 12, 1981.

Dixon, R. L. 1980. Toxic responses of the reproductive system. In J. Doull, C. D. Klaasen, and M. O. Amdur, eds., Casarett and Doull's Toxicology, Macmillan, New York.

Doull, J., Klaasen, C. D., and Amdur, M. O. 1986. Casarett and Doull's Toxicology, Macmillian, New York. 
MARTIN MARIETTA

ENERGY SYSTEMS, INC.

Oak Ridge National Laboratory
Pollutant Assessments Group

Health and Safety

Procedures Manual
Sect. 8 Rev. 2

Date 6/92

Page 47 of 50

SUBJECT: STANDARD OPERATING PROCEDURES

Grant, H. D., Murray, R. H., Jr., and Bergeron, J. David, eds. 1971. Emergency Care, Fourth Ed. Prentice Hall, Inc., Englewood Cliffs, N.J.

Merck, Sharp, and Dohme, Ltd. 1980. The Merck Index, 9th Ed., Rathway, N.J.

NIOSH. 1985. Occupational safety and health guidance manual for hazardous waste site activities. National Institute for Occupational Safety and Health, Occupational Safety and Health Administration, U.S. Coast Guard, and Environmental Protection Agency, DHHS (NIOSH) Publication 85-115, January 1990.

NIOSH. 1990. NIOSH pocket guide to chemical hazards. U.S. Department of Health and Human Services, DHHS (NIOSH) Publication 85-11, September 1985.

Occupation Health Guidelines for Chemical Hazards, January 1981, Part 1 of 3PB83-154609.

Occupational Health Guidelines for Chemical Hazards, January 1981, Part 2 of 3PB83-154609.

Occupational Health Guidelines for Chemical Hazards, January 1981, Part 3 of 3PB83-154609.

Pocket Guide to Chemical Hazards. 1990. NIOSH/OSHA, DHEW (NIOSH) Pub. No. 78-120.

Registry of Toxic Effects of Chemical Substances. 1978. 8th Ed., NIOSH.

Sax, N. I. 1987. Dangerous Properties of Industrial Materials, Sixth Ed., Van Nostrand Reinhold Co.

Threshold Limit Values and Biological Exposure Indices for 1990-1991. 1986. QV-600-A54 1990-91-3-44560066969 4.

Threshold Limit Values for Chemical Substances and Physical Agents in the Work Environment, 1990-1991. 
MARTIN MARIETTA

ENERGY SYSTEMS, INC.

Oak Ridge National Laboratory
Pollutant Assessments Group

Health and Safety

Procedures Manual
Sect. 8 Rev. 2

Date $6 / 92$

Page 48 of 50

\section{SUBJECT: STANDARD OPERATING PROCEDURES}

Table 8.2 Illumination recommendations

\begin{tabular}{|c|c|}
\hline Area & $\begin{array}{l}\text { Footcandles } \\
\text { on tasks }\end{array}$ \\
\hline \multicolumn{2}{|l|}{ Assembly } \\
\hline Rough easy seeing & 30 \\
\hline Rough difficult seeing & 50 \\
\hline Medium & 100 \\
\hline Fine & $500^{b}$ \\
\hline Extra fine & $1000^{b}$ \\
\hline \multicolumn{2}{|l|}{ Building (construction) } \\
\hline General construction & 10 \\
\hline Excavation work & 2 \\
\hline \multicolumn{2}{|l|}{ Building exteriors } \\
\hline \multicolumn{2}{|l|}{ Entrances } \\
\hline Active (pedestrian and/or conveyance) & 5 \\
\hline Inactive normally locked, infrequently used & 1 \\
\hline Vital locations or structures & 5 \\
\hline Building surrounds & 1 \\
\hline \multicolumn{2}{|l|}{ Garages-automobile and truck } \\
\hline \multicolumn{2}{|l|}{ Service garages } \\
\hline Repairs & 100 \\
\hline Active traffic areas & 20 \\
\hline \multicolumn{2}{|l|}{ Parking garages } \\
\hline Entrance & 50 \\
\hline Traffic lanes & 10 \\
\hline Storage & 5 \\
\hline \multicolumn{2}{|l|}{ Inspection } \\
\hline Ordinary & 50 \\
\hline Difficult & 100 \\
\hline Highly difficult & 200 \\
\hline Very difficult & $500^{b}$ \\
\hline Most difficult & $1000^{b}$ \\
\hline
\end{tabular}


MARTIN MARIETTA

ENERGY SYSTEMS, INC.

Oak Ridge National Laboratory
Pollutant Assessments Group

Health and Safety

Procedures Manual
Sect. 8 Rev. 2

Date $6 / 92$

Page 49 of 50

SUBJECT: STANDARD OPERATING PROCEDURES

Table 8.2 (continued)

\begin{tabular}{cc}
\hline Area & $\begin{array}{c}\text { Footcandles } \\
\text { on tasks }^{\circ}\end{array}$ \\
\hline
\end{tabular}

Loading and unloading platforms 20

$\begin{array}{ll}\text { Freight car interiors } & 10\end{array}$

$\begin{array}{ll}\text { Locker rooms } & 20\end{array}$

Machine shops

Rough bench and machine work $\quad 50$

Medium bench and machine work, ordinary $\quad 100$

automatic machines, rough grinding, medium

buffing and polishing

Fine bench and machine work, fine automatic

$500^{b}$

machines, medium grinding fine buffing and

polishing

Extra-fine bench and machine work, grinding,

$1000^{b}$

fine work

Materials handling

Wrapping, packing, labeling $\quad 50$

Picking stock, classifying $\quad 30$

Loading, trucking $\quad 20$

$\begin{array}{ll}\text { Inside truck bodies and freight cars } & 10\end{array}$

\section{Offices}

Cartography, designing, detailed drafting 200

Accounting, auditing, tabulating bookkeeping, $\quad 150$

business machine operation, reading poor

reproductions, rough layout drafting

Regular office work, reading good reproductions, $\quad 100$

reading or transcribing handwriting in hard

pencil or on poor paper, active filing, index

references, mail sorting

Reading or transcribing handwriting in ink or medium pencil on good quality paper, intermittent filing

Reading high-contrast or well-printed material, 0 tasks and areas not involving critical or prolonged seeing such as conferring, interviewing inactive files, washrooms 
MARTIN MARIETTA

ENERGY SYSTEMS, INC.

Oak Ridge National Laboratory
Pollutant Assessments Group

Health and Safety

Procedures Manual
Sect. 8 Rev. 2

Date $6 / 92$

Page 50 of 50

\section{SUBJECT: STANDARD OPERATING PROCEDURES}

Table 82 (continued)

\begin{tabular}{lc}
\hline \multicolumn{1}{c}{ Area } & $\begin{array}{c}\text { Footcandles } \\
\text { on tasks }^{\circ}\end{array}$ \\
\hline $\begin{array}{l}\text { Corridors, elevators, escalators, stairway } \\
\text { Storage rooms or warehouses } \\
\text { Inactive }\end{array}$ & 20 \\
Rough bulky & \\
Medium & 10 \\
Fine & 20 \\
\hline
\end{tabular}

${ }^{a}$ Minimum on the task at any time.

${ }^{b}$ Can be obtained with a combination of general lighting plus specialized supplementary lighting. Care should be taken to keep within the recommended brightness ratios. These seeing tasks generally involve the discrimination of fine detail for long periods of time and under conditions of poor contrast. The design and installation of the combination system must not only provide a sufficient amount of light, but also the proper direction of light, diffusion, color and eye protection. As far as possible it should eliminate direct and reflected glare as well as objectionable shadows. Intrinsically safe illumination equipment should be used in situations where combustible atmospheres may exits. 
MARTIN MARIETTA

ENERGY SYSTEMS, INC.

Oak Ridge National Laboratory
Pollutant Assessments Group

Health and Safety

Procedures Manual
Sect. 9 Rev. 2

Date 6/92

Page 1 of 8

SUBJECT: PERSONNEL PROTECTION-LEVEL D

\section{PERSONNEL PROTECTION_LEVEL D}

\subsection{PURPOSE}

To describe the equipment and procedures required for the health and safety of personnel who will perform field activities in nonhazardous material conditions in standard work clothes (Level D protective clothing) based on OSHA recommendations.

\subsection{APPLICABIITY}

To eliminate/limit the spread of contaminated materials that workers may be exposed to, all site investigation team members will use Level $\mathrm{D}$ protective clothing as a primary work uniform. When work functions preclude absorption, ingestion, or inhalation exposure to any levels of hazardous substances, site personnel will use Level $D$ protective clothing.

Although Level D protection is used under the conditions specified, chemical-resistant gloves, outer boots, and Tyvek" (Tyvek Corporation) or other applicable chemicalresistant clothing may be worn as a conservative measure of protection and to maintain personal hygiene. The donning of personal protective clothing may vary depending on the type of task. All site personnel must contact the SPM or SSHO and read the site-specific health and safety plan to ascertain personal protection requirements before entering an investigation site (Fig. 9.1).

\subsection{PROCEDURES}

\subsubsection{Office}

1. Each site-specific health and safety plan will specify the procedures and equipment required for personnel protective clothing for individual tasks. The selection of appropriate protective gear is based on known hazards and contingencies. Complete protection calls for assembling a set of gear, including hard hat, safety glasses and face shield if needed, body covering (coveralls, 
MARTIN MARIETTA

ENERGY SYSTEMS, INC.

Oak Ridge National Laboratory
Pollutant Assessments Group

Health and Safety

Procedures Manual
Sect. 9 Rev. 2

Date 6/92

Page 2 of 8

\section{SUBJECT: PERSONNEL PROTECTION-LEVEL D}

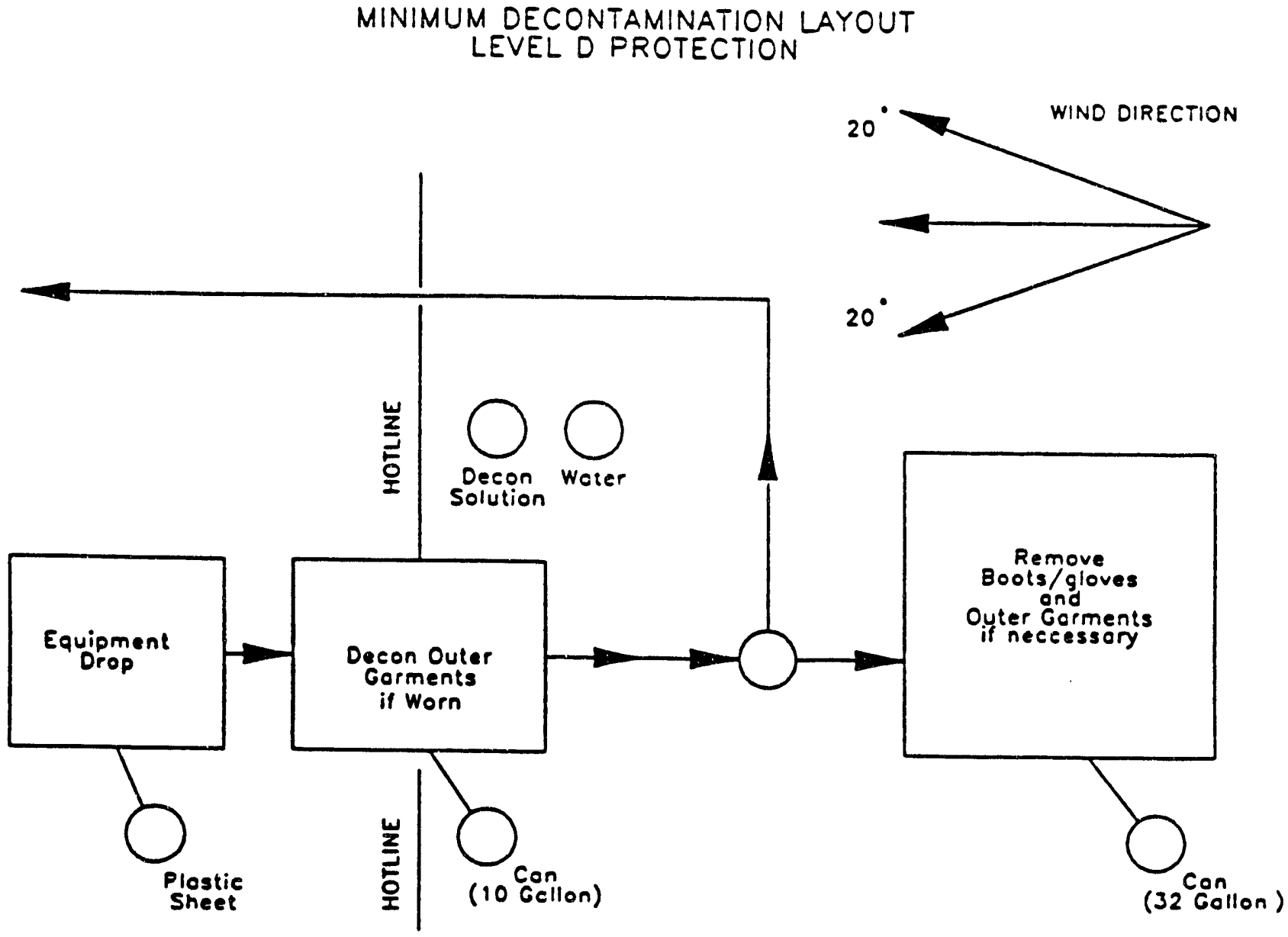

Fig. 9.1. Minimum decontamination layout-Level D protection. 
MARTIN MARIETTA

ENERGY SYSTEMS, INC.

Oak Ridge National Laboratory
Pollutant Assessments Group

Health and Safety

Procedures Manual
Sect. 9 Rev. 2

Date 6/92

Page 3 of 8

SUBJECT: PERSONNEL PROTECTION_LEVEL D

splash suits, and gloves), safety shoes (steel toes and shanks), an self-contained escape breathing apparatus, and cooling devices.

All protective clothing will meet OSHA and other applicable standards, which are normally based on scientific industry standards.

2. Section 9.4 presents a list of items necessary for Level $D$ protection. This list provides general guidance and can be modified to meet specific site work activities or features. Figure 9.1 shows the minimum decontamination layout for Level D protection.

3. Necessary clothing, protective gear, and PPE. Consult the site-specific health and safety plan to ensure that necessary decontamination materials are available and personal hygiene practices are accounted for.

\section{3 .2 Field}

Depending on the site-specific health and safety plan, a working zone for containment of potential contamination (hotline) may be established as a conservative measure before initiating field activities. An area should be designated for personnel to thorcughly remove visible soil by brushing off clothing and boots and by washing with soap and water. Although Level D areas should not subject personnel to hazardous exposures, caution will always be used to prevent the potential spread of any unknown contaminants. In the event of suspected or known minimal presence of hazardous materials, personnel will upgrade PPE to modified Level D (Level D+) protection (Sect. 9.5); Level C protection (Sect. 10) will be donned if exposure levels come close to or exceed mandated limits on known hazardous materials.

\subsection{OPERATION}

The following procedures are recommended for Level $D$ protection. These measures represent suggested guidelines and may be modified to meet site-specific conditions.

1. Deposit all equipment used on-site at the designated drop zone, and remove visible soil from clothing and boots.

2. If dusty conditions have been encountered, use water-dampened paper towels to remove dust from hard hat and/or safety glasses/goggles. Place used paper towels in trash sack. 
MARTIN MARIETTA

ENERGY SYSTEMS, INC.

Oak Ridge National Laboratory
Pollutant Assessments Group

Health and Safety

Procedures Manual
Sect. 9 Rev. 2

Date 6/92

Page 4 of 8

SUBJECT: PERSONNEL PROTECTION_LEVEL D

The equipment and procedures needed to perform protection and decontamination measures for Level $D$ personnel protection include

1. Uniform

a. Personnel protection will consist of a basic work uniform.

b. A hard hat, safety glasses, hard-toed boots or shoes, and chemically resistant gloves or overboots may be required.

2. Equipment
a. Plastic trash bags
30-gal capacity
20-gal capacity

b. 3 plastic washtubs (5- or 10-gal capacity), one each for washing boots and gloves and one for rinsing

c. Paper towels

d. Liquid hand soap

e. Disposable wipes

f. Water transport containers (1-, 2-, or 5-gal capacity)

g. Soft-bristled scrub brushes

h. Plastic tarpaulin (minimum $5 \mathrm{ft}$ by $5 \mathrm{ft}$ )

i. Garden sprayer for transporting and dispensing clean rinse water

3. All workers will wash hands and face before leaving the site.

4. All workers will change clothing and shower as soon as possible on completion of the day's work activities.

\subsection{LEVEL D+ PROTECTION}

If an upgrade from Level $D$ protection is required, the procedures outlined in the following will be instituted in addition to site-specific requirements determined by the SSHO. This upgrade (Level $\mathrm{D}+$ ) will aiso require replanning the work and establishing a personnel decontamination station. In the field, the following decontamination procedures will be followed.

1. Locate a decontamination area a safe distance upwind from the sampling area.

2. Establish a personnel decontamination station.

3. On leaving the contamination area, personnel should proceed through the appropriate contamination reduction sequence.

4. Leave all protection gear on-site during lunch break following decontamination procedures.

The maximum decontamination layout for Level $\mathrm{D}+$ is described in Table 9.1. 
MARTIN MARIETTA

ENERGY SYSTEMS, INC.

Oak Ridge National Laboratory
Pollutant Assessments Group

Health and Safety

Procedures Manual
Sect. 9 Rev. 2

Date 6/92

Page 5 of 8

SUBJECT: PERSONNEL PROTECTION-LEVEL D

Table 9.1. Measures for Level D+ Decontamination

Station 1: Segregated equipment drop

Station 2: Boot cover and glove wash

Station 3: Boot cover and glove rinse

Station 4: Tape removal

Station 5: Outer glove removal

Station 6: Suit, glove, and boot wash

Station 7: Suit, boot, and glove rinse

Station 8: Safety boot removal

Station 9: Tyvek suit removal
1. Deposit equipment used on-site (tools, sampling devices and containers, monitoring instruments, radios, clipboards, etc.) on plastic tarpaulins or in designated plastic-lined containers. Segregation at the drop reduces the probability of cross-contamination

2. Scrub boot covers and gloves with decontamination solution or detergent and water

3. Rinse decontamination solution from Station 2 using copious amounts of water

4. If used, remove tape around rubber boot covers and gloves and deposit in container lined with plastic trash bag

5. Remove gloves and deposit in container lined with plastic trash bag

6. If gross contamination exists, wash Tyvek suit, gloves, and safety boots. Scrub with long-handled scrub brush and decontamination solution

7. If gross contamination exists, rinse decontamination solution off of suit, boots, and gloves using water. Repeat as many times as necessary

8. Remove safety boots and deposit in container lined with plastic trash bag

9. Remove Tyvek suit. Deposit in container lined with plastic trash bag 


\section{SUBJECT: PERSONNEL PROTECTION-LEVEL D}

\subsection{LEVEL D+ EQUIPMENT DECONTAMINATION}

This procedure applies to all equipment that comes in contact with soil, sediment, and water samples, such as sampler, trowel, hand spade, spoon, straight bar, and pan. Equipment and supplies necessary for this task are

- 5-gal water jug (filled with tap water)

- plastic tub or bucket

- three stainless steel baths

- scrub brushes (plastic or fiber bristles)

- wire brush

- disposable wipes

- laboratory detergent

- plastic trash can liners

- distilled water in wash bottle

- pesticide-grade hexane and pesticide-grade methanol (in Teflon wash bottle)

- $10 \%$ HNO solution ( $1 \%$ if carbon steel is used).

NOTE: If equipment is muddy, wash it in tap water in plastic bucket or tub and then with soapy water in stainless steel bath. Rinse with tap water, and dry with a disposable wipe. A different scrub brush should be used with each bath.

The following decontamination procedures are acceptable for all sampling equipment.

1. Wash and scrub with detergent (low phosphate if phosphate is an analyte).

2. Rinse with tap water.

3. Rinse with $10 \%$ HNO ( $1 \%$ if carbon steel is used).

4. Rinse with tap water.

5. Rinse with methanol or ethanol; then, rinse with hexane.

6. Rinse with deionized or distilled analyte-free water.

7. Air dry.

8. Wrap in aluminum foil.

If metals are not being sampled for, steps 3 and 4 can be omitted; if organics are not being sampled, step 5 can be omitted. Solvents must be specified as pesticide grade or better. Preferably, all decontamination should be done in a staging area or at the lab. Equipment should be cleaned once a day in a batch so that the final rinsate may be collected for field equipment blanks. If this is not possible, a rinsate blank from each piece of sampling equipment should be taken before and after the sampling/decontamination has been completed. After cleaning, field equipment may be placed temporarily on polyethylene sheeting, but must ultimately be wrapped in aluminum 
MARTIN MARIETTA

ENERGY SYSTEMS, INC.

Oak Ridge National Laboratory
Pollutant Assessments Group

Health and Safety

Procedures Manual
Sect. 9 Rev. 2

Date 6/92

Page 7 of 8

SUBJECT: PERSONNEL PROTECTION-LEVEL D

foil. (Care must be taken when choosing solvent types to avoid any potential airborne source of contamination.) All drilling equipment, well screens and casings, backhoes, dredges, augers, and other heavy equipment must be steam cleaned or washed with a highpressure hot-water system before use.

\subsection{POSTOPERATION}

\subsubsection{Field}

All disposable clothing, plastic sheeting, and waste materials used during the operation must be double-bagged and either contained on-site or removed to an approved off-site disposal facility as directed by the SPM. Decontamination and rinse solutions should be contained on-site or removed to an approved disposal facility. Reusable rubber clothing should be dried and prepared for future use. (If gross contamination has occurred, additional decontamination or disposal may involve on-site drumming in 55-gal containers for subsequent disposal at approved facilities.) Cloth items should be bagged and removed from the site for final cleaning or disposal. All wash tubs, pail containers, etc., should be thoroughly washed, rinsed, and dried prior to removal from the site.

\subsubsection{Office}

All unused items should be returned to the proper equipment storage facilities. The procurement coordinator should be apprised of all stock items that need to be ordered to replenish the inventory.

\subsection{REFERENCES}

Code of Federal Regulations-29, Pt. 1900-1910, 1990.

Code of Federal Regulations-30, Pt. 1-199, 1988.

Doull, J., Klaasen, C. D., and Amdur, M. O. 1986. Casarett and Doull's Toxicology, Macmillan, New York.

DOE. 1985. Comprehensive Environmental Response, Compensation, and Liability Act Program. DOE Order 5480.14. U.S. Department of Energy, Washington, D.C.

EPA 1981. Health and safety requirements for employees engaged in field activities. Environmental Protection Agency Order 1440.1. U.S. Environmental Protection Agency, July 12, 1981. 
MARTIN MARIETTA

ENERGY SYSTEMS, INC.

Oak Ridge National Laboratory
Pollutant Assessments Group

Health and Safety

Procedures Manual
Sect. 9 Rev. 2

Date 6/92

Page 8 of 8

\section{SUBJECT: PERSONNEL PROTECTION-LEVEL D}

NIOSH. 1985. Occupational safety and health guidance manual for hazardous waste site activities. National Institute for Occupational Safety and Health, Occupational Safety and Health Administration, U.S. Coast Guard, and Environmental Protection Agency, DHHS (NIOSH) Publication 85-115, October 1985.

Occupation Health Guidelines for Chemical Hazards, January 1981, Part 1 of 3PB83-154609.

Occupational Health Guidelines for Chemical Hazards, January, 1981, Part 2 of 3PB83-154609.

Occupational Health Guidelines for Chemical Hazards, January 1981, Part 3 of 3PB83-154609. 


\section{SUBJECT: PERSONNEL PROTECTION-LEVEL C}

\section{PERSONNEL PROTECTION-LEVEL C}

\subsection{PURPOSE}

To describe the equipment and procedures used when certain types of exposure levels are anticipated. Level $C$ protective measures will be required for protection and decontamination of personnel who will perform field activities in Level $\mathrm{C}$ protective clothing and equipment.

\subsection{APPLICABחITY}

Protective clothing, full-face air-purifying respirators, and site-specific equipment must be worn by personnel when field activities involve known or suspected hazardous substances and do not require self-contained breathing apparatuses or exceed IDLH levels (Table 10.1). The equipment needed to perform minimum decontamination measures for

\section{Table 10.1 Equipment needed for Level $\mathrm{C}$ protection}

A. 1. Chemical-resistant clothing, inner and outer gloves, and outer boots, depending on the site-specific PPE determination

2. Full-face respirator with high-efficiency particulate aerosol (HEPA) cartridges

3. Extra respirator cartridges

4. Roll of duct tape

5. Cloth glove inserts

B. 1. Hard hat (if required)

2. Hard-toed boots (if required)

3. Safety glasses (if required)

Sources: NIOSH 1985; U.S. EPA 1984.

Level $\mathrm{C}$ protection are addressed in Table 10.2. The procedures described are cuidelines for the maximum and minimum amount of decontamination required. 
MARTIN MARIETTA

ENERGY SYSTEMS, INC.

Oak Ridge National Laboratory
Pollutant Assessments Group

Health and Safety

Procedures Manual
Sect. 10 Rev. 2

Date $6 / 92$

Page 2 of 12

SUBJECT: PERSONNEL PROTECTION-LEVEL C

PROJECT MANAGER \SUPERVISOR

DATE

Table 10.2. Equipment needed to perform minimum decontamination measures for Level C

Station 1: a. Various size washtubs

b. Plastic trash bags

c. Plastic drop cloths

Station 2: a. Containers (20-30 gal)

b. Decontamination solution

c. Rinse water

d. 2 to 3 long-handled, soft-bristled scrub brushes

Station 3: a. Containers (20-30 gal)

b. Plastic trash bags

c. Bench or stools
Station 5: a. Containers (20-30 gal)

b. Plastic trash bags

c. Bench or stools

Station 6: a. Plastic sheets

b. Basin or bucket

c. Soap and towels

d. Bench or stools

Station 7: a. Water

b. Soap

c. Tables

d. Wash basin or bucket

Station 4: a. Chemical-resistant boot covers

b. Chemical-resistant gloves

c. Paper towels

Sources: NIOSH 1985; U.S. EPA 1984.

NOTE: Donning of any chemical-resistant clothing will increase heat stress conditions and will dictate the need for more extensive heat stress monitoring (Sect. 8.12).

The establishment of decontamination zones is site-specific; these zones are dependent on the types of contamination and the work performed. When the decontamination zone is no longer required, contaminated wash and rinse solutions and articles must be contained and disposed of appropriately. Disposal must be in compliance with site-specific and/or installation requirements and any applicable federal and state regulations (Sect. 8.7.1). 
MARTIN MARIETTA

ENERGY SYSTEMS, INC.

Oak Ridge National Laboratory
Pollutant Assessments Group

Health and Safety

Procedures Manual
Sect. 10 Rev. 2

Date $6 / 92$

Page 3 of 12

SUBJECT: PERSONNEL PROTECTION-LEVEL C

\subsection{PROCEDURES}

\subsubsection{Office}

1. The selection of the appropriate level of personnel protection and decontamination is site-specific and must be coordinated with the SSHO or SPM. Considerations for selection include work activity, known or suspected contaminants, previous experience at the site, and health and safety requirements.

2. The site health and safety plan will contain details for ultimate disposal of protective clothing and wastewater. The packaging and disposal plans must be approved by the installation authorities and/or the SPM responsible for waste disposal. All on-site personnel will be informed of the proper disposal of protective clothing and decontamination solutions. These procedures closely follow those listed in Sect. 8.6.

3. Table 10.3 provides guidance on equipment selection for those instances in which maximum decontamination measures for Level $\mathrm{C}$ protection are required. These measures present only general equipment guidance. The selection of equipment must be site-specific in order to incorporate unusual work activities or site features.

\subsubsection{Field}

1. Prior to initiating field activities, site work zones (hotlines) shall be established to reduce the accidental spread of hazardous substances. Establishment of work zones should be site-specific and, whenever possible, coordinated with the SSHO at the time the health and safety plan is prepared. Considerations for establishment of work zones shall include wind direction, weather conditions, emergency situations, changes in site activities, and egress.

2. Figure 10.1 presents an example of a minimum decontamination layout for Level $\mathrm{C}$ protection. An example of the maximum decontamination layout for Level $\mathrm{C}$ protection is presented in Fig. 10.2. It is important to note that the examples may be modified according to site-specific conditions.

\subsection{OPERATION}

\subsubsection{Maximum Decontamination Measures}

The maximum measures for Level $\mathrm{C}$ decontamination stations described in Table 10.4 represent guidelines and may be modified according to site-specific conditions. 
MARTIN MARIETTA

ENERGY SYSTEMS, INC.

Oak Ridge National Laboratory
Pollutant Assessments Group

Health and Safety

Procedures Manwal
Sect. 10 Rev. 2

Date 6/92

Page 4 of 12

SUBJECT: PERSONNEL PROTECTION-LEVEL C

Table 10.3. Equipment needed to perform maximum decontamination measures for Level $\mathrm{C}$

Station 1: a. Various size containers

b. Plastic trash bags

c. Plastic drop cloths

Station 2: a. Containers (20-30 gal)

b. Decontamination solution or detergent water

c. 2 to 3 long-handled, soft-bristled scrub brushes

Station 3: a. Containers (20-30 gal) or high-pressure spray unit

b. Water

c. 2 to 3 long-handled, soft-bristled scrub brushes

Station 4: a. Containers (20-30 gal)

b. Plastic trash bags

Station 5: a. Containers (20-30 gal)

b. Plastic trash bags

c. Bench or stools

Station 6: a. Containers (20-30 gal)

b. Plastic liners

Station 7: a. Containers (20-30 gal)

b. Decontamination solution or detergent water

c. 2 to 3 long-handled, soft-bristled scrub brushes

Station 8: a. Containers (20-30 gal) or high-pressure spray unit

b. Water

c. 2 to 3 long-handled, soft-bristled scrub brushes

Station 9: a. Full-face respirators and cartridges depending upon type of contamination

b. Tape

c. Boot covers

d. Gloves

Station 10: a. Containers (20-30 gal)

b. Plastic trash bags

c. Bench or stools

d. Boot jack 
MARTIN MARIETTA

ENERGY SYSTEMS, INC.

Oak Ridge National Laboratory
Pollutant Assessments Group

Health and Safery

Procedures Manual
Sect. 10 Rev. 2

Date 6/92

Page 5 of 12

SUBJECT: PERSONNEL PROTECTION-LEVEL C

Table 10.3 (continued)

Station 11: a. Rack

b. Tarpaulins

c. Bench or stools

Station 12: a. Table

Station 13: a. Basin or bucket

b. Decontamination solution

c. Small table

Station 14: a. Water

b. Basin or bucket

c. Small table

Station 15: a. Containers (20-30 gal)

b. Plastic trash bags

Station 16: a. Containers (20-30 gal)

b. Plastic trash bags

Station 17: a. Containers (20-30 gal)

b. Plastic trash bags

Station 18: a. Water

b. Soap

c. Small table

d. Basin or bucket

e. Field showers

f. Towels

Station 19: a. Dressing shelter is needed in inclement weather

b. Tables

c. Chairs

d. Lockers

e. Cloths

Sources: NIOSH 1985; U.S. EPA 1984. 
MARTIN MARIETTA

ENERGY SYSTEMS, INC.

Oak Ridge National Laboratory
Pollutant Assessments Group

Health and Safety

Procedures Manual
Sect. 10 Rev. 2

Date 6/92

Page 6 of 12

SUBJECT: PERSONNEL PROTECTION-LEVEL C

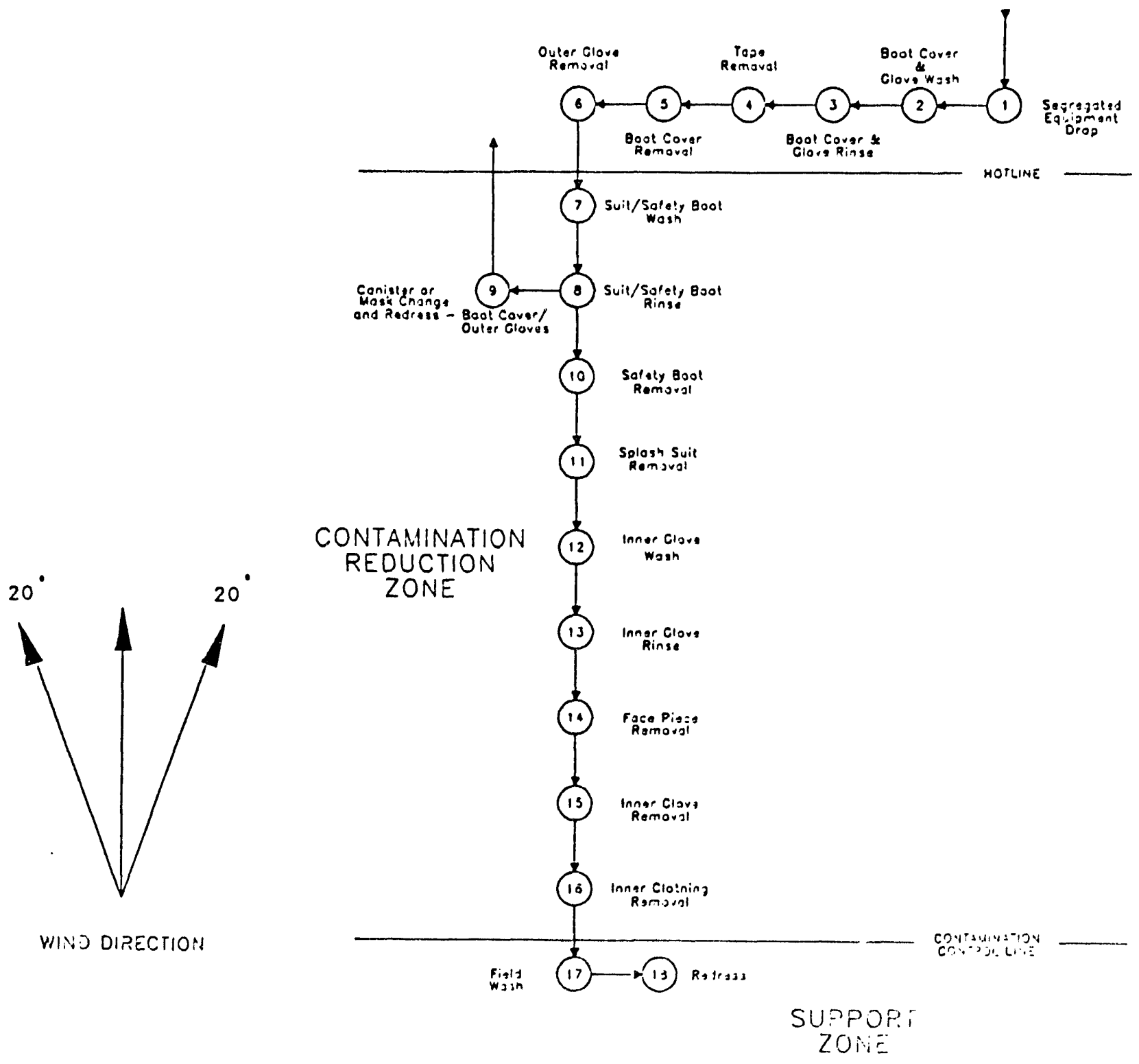

Fig. 10.1 Minimum decontamination layout-Level C protection 
MARTIN MARIETTA

ENERGY SYSTEMS, INC.

Oak Ridge National Laboratory
Pollutant Assessments Group

Health and Safery

Procedures Manual
Sect. 10 Rev. 2

Date 6/92

Page 7 of 12

SUBJECT: PERSONNEL PROTECTION_LEVEL C
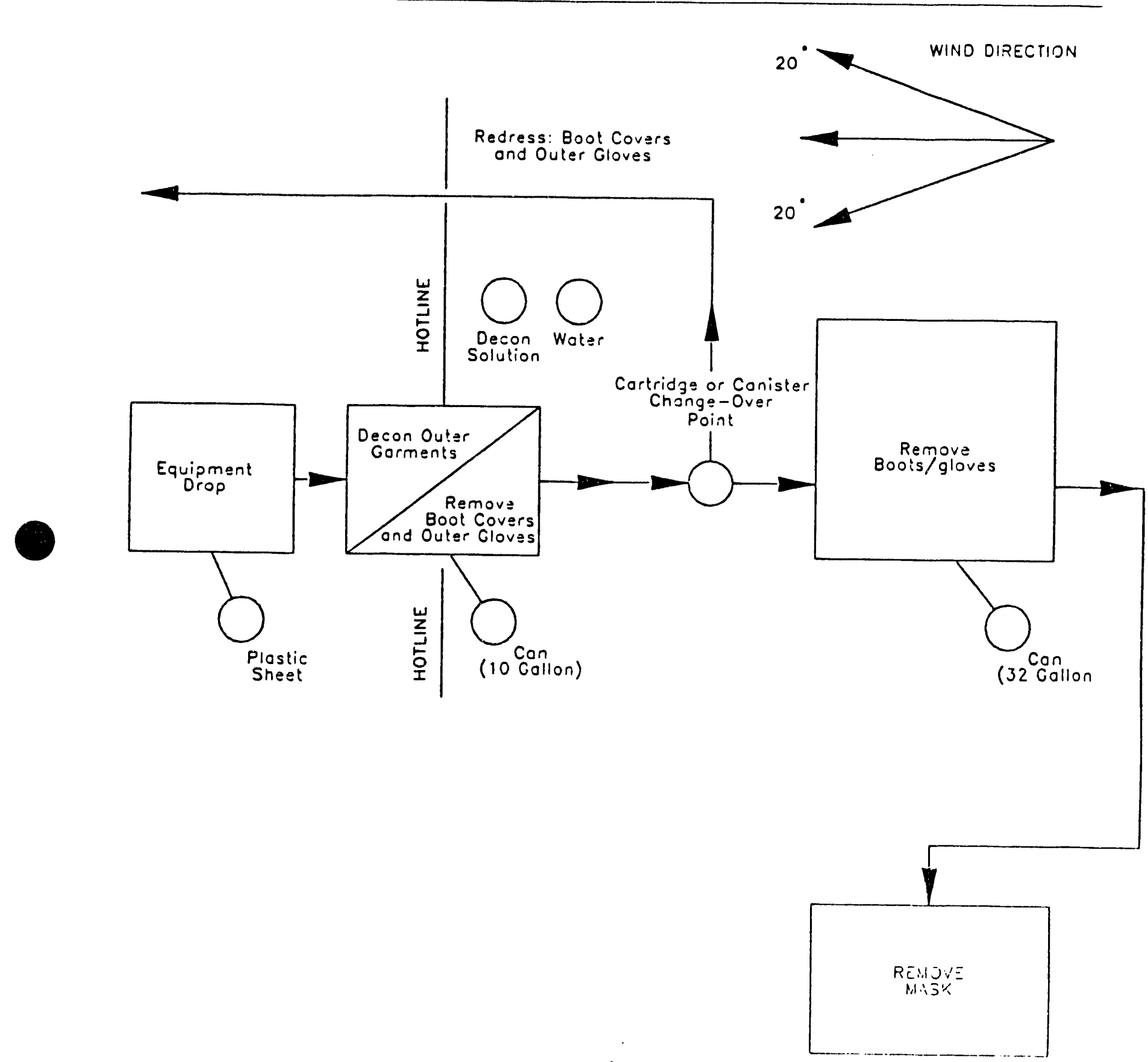

Fig. 10.2 Maximum decontamination layout-Level C protection 
MARTIN MARIETTA

ENERGY SYSTEMS, INC.

Oak Ridge National Laboratory
Pollutant Assessments Group

Health and Safety

Procedures Manual
Sect. 10 Rev. 2

Date 6/92

Page 8 of 12

SUBJECT: PERSONNEL PROTECTION_LEVEL C

Table 10.4. Maximum measures for Level $\mathbf{C}$ decontamination stations

Station 1: $\quad$ Segregated equipment

Station 2:

Boot cover and glove wash

Station 3: $\quad$ Boot cover and glove rinse

Station 4: $\quad$ Tape removal

Station 5: $\quad$ Boot cover removal

Station 6: Outer glove removal

Station 7: $\quad$ Suit and boot wash

Station 8: $\quad$ Suit and boot rinse

Station 9: Canister or mask change
Deposit equipment used on-site (tools, sampling devices and containers, monitoring instruments, radios, clipboards, etc.) on plastic tarpaulins or in designated containers lined with plastic trash bags. Segregation at the drop reduces the probability of cross-contamination. During hot weather, a cool-down station may be set up within this area

Scrub outer boot covers and gloves with decontamination solution or detergent and water

Rinse off decontamination solution from Station 2 using copious amounts of water

Remove tape around boots and gloves and deposit in container lined with plastic trash bag

Remove boot covers and deposit in container with plastic trash bag

Remove outer gloves and deposit in container lined with plastic trash bag

Wash splash suit, gloves, and safety boots. Scrub with long-handled scrub brush and decontamination solution

Rinse off decontamination solution using water. Repeat as many times as necessary

If worker leaves exclusion zone mask to change canister (or mask), this is the last step in the decontamination procedure. Worker's canisters are exchanged, new outer gloves and boot covers donned, and joints taped; worker returns to duty 
MARTIN MARIETTA

ENERGY SYSTEMS, INC.

Oak Ridge National Laboratory
Pollutant Assessments Group

Health and Safety

Procedures Manual
Sect. 10 Rev. 2

Date 6/92

Page 9 of 12

SUBJECT: PERSONNEL PROTECTION-LEVEL C

Table 10.4 (continued)

Station 10: Safety boot removal

Station 11: Splash suit removal

Station 12: Inner glove rinse

Station 13: Inner glove wash

Station 14: Face piece removal

Station 15: Inner glove removal

Station 16: Inner clothing removal

Station 17: $\quad$ Field wash

Station 18: Re-dress
Remove safety boots and deposit in container lined with plastic trash bag

With assistance of helper, remove splash suit. Deposit in container lined with plastic trash bag

Wash inner gloves with decontamination solution

Rinse inner gloves with water

Remove face piece. Deposit in container lined with plastic trash bag. Avoid touching face with fingers

Remove inner gloves and deposit in container lined with plastic trash bag

Remove clothing soaked with perspiration and place in container lined with plastic trash bag. Do not wear inner clothing off-site since there is a possibility that small amounts of contaminants might have been transferred in removing the outer clothing

Shower if highly toxic, skin-corrosive, or skin absorbable materials are known or suspected to be present. Wash hands and face if shower is not available

Put on clean clothes. 
MARTIN MARIETTA

ENERGY SYSTEMS, INC.

Oak Ridge National Laboratory
Pollutant Assessments Group

Health and Safety

Procedures Manual
Sect. 10 Rev. 2

Date 6/92

Page 10 of 12

SUBJECT: PERSONNEL PROTECTION-LEVEL C

\subsubsection{Modification of Maximum Decontamination Measures}

Depending on site-specific conditions and circumstances, modification to maximum decontamination measures may be permissible. Two examples of situations in which the maximum decontamination measures may be modified are described in the following.

1. Situation 1-The individual entering the contamination reduction zone is expected to be minimally contaminated. Extremely skin-corrosive materials are not present. No outer gloves or boot covers are worn. The inner gloves are not contaminated.

The following decontamination stations, as described in Table 10.4, would be used in this situation: Stations $1,7,8,10,11,14,15,16$, and 17.

2. Situation 2-The individual entering the contamination reduction zone is expected to be minimally contaminated. Extremely toxic or skin-corrosive materials are not present. No outer gloves or boot covers are worn. The inner gloves are not contaminated. The individual needs a new canister or mask and will return to the exclusion zone.

The following decontamination stations, as described in Table 10.4, would be used in this situation: Stations $1,7,8$, and 9.

\subsubsection{Minimum Decontamination Measures}

The minimum decontamination measures for Level $\mathbf{C}$ decontamination stations are described in Table 10.5. These measures represent guidelines only and may be modified according to site-specific conditions. Equipment decontamination procedures for Level C conditions will be the same as those used for Level D+ equipment decontamination (Sect. 9.6).

\subsection{POSTOPERATION}

\subsubsection{Field}

At the completion of field activities, all contaminated wash and rinse waters, decontamination solutions, and contaminated articles must be properly disposed of. The disposal methods must comply with the site-specific health and safety plan and with installation requirements. The SPM is responsible for the safe disposal of contaminated materials. Planning for the proper disposal should be included during office preparations prior to field activities. The site-specific work and health and safety plans, installation requirements, and state and federal regulations should be consulted (Sect. 8.7.1). 
MARTIN MARIETTA

ENERGY SYSTEMS, INC.

Oak Ridge National Laboratory
Pollutant Assessments Group

Health and Safety

Procedures Manual
Sect. 10 Rev. 2

Date 6/92

Page 11 of 12

SUBJECT: PERSONNEL PROTECTION-LEVEL C

Table 10.5. Minimum measures for Level $\mathbf{C}$ protection

Station 1: Equipment drop

Deposit equipment used on-site (tools, sampling devices and containers, monitoring instruments, radios, clipboards, etc.) on plastic drop cloths. Segregation at the drop reduces probability of crosscontamination. During hot weather, a cool-down station may be set up within this area

Station 2: Outer garment, boots, and gloves

Scrub outer boots, outer gloves, and splash suit with decontamination solution or wash and rinse detergent water. Rinse off using water

Station 3: $\quad$ Outer boot and glove removal

Remove outer boots and gloves, deposit in container lined with plastic trash bag

Station 4: $\quad$ Canister or mask change

If worker leaves exclusion zone to change canister (or mask), this is the last step in the decontamination procedures.

Worker's canisters are exchanged, new outer gloves and boot covers donned, and joints taped; worker returns to duty

Station 5: $\quad$ Boot, glove, and outer garment removal

Remove boots, chemical-resistant splash suit, and inner gloves and deposit in separate containers lined with plastic trash bags

Station 6: $\quad$ Face piece removal

Remove face piece. Avoid touching face with fingers. Deposit facepiece on plastic sheet

Station 7: Field wash Wash hands and face thoroughly. Shower as soon as possible

Station 8: $\quad$ Re-dress

Put on clean clothes if necessary

Sources: NIOSH 1985; U.S. EPA 1984. 
MARTIN MARIETTA

ENERGY SYSTEMS, INC.

Oak Ridge National Laboratory
Pollutant Assessments Group

Health and Safety

Procedures Manual
Sect. 10 Rev. 2

Date 6/92

Page 12 of 12

SUBJECT: PERSONNEL PROTECTION-LEVEL C

\subsubsection{Office}

All unused and properly decontaminated equipment will be returned to the designated storage facilities. The procurement coordinator should be apprised of all stock items that need to be ordered to replenish the inventory.

\subsection{REFERENCES}

Code of Federal Regulations-30, Pt. 1-19, 1986. Code of Federal Regulations-29, Pt. 1900-1910, 7/87.

DOE. 1985. Comprehensive Environmental Response, Compensation, and Liability Act Program. DOE Order 5480.14. U.S. Department of Energy, Washington, D.C.

Doull, J., Klaasen, C. D., and Amdur, M. O. 1986. Casarett and Doull's Toxicology, Macmillan, New York.

EPA. 1981. Health and safety requirements for employees engaged in field activities. Environmental Protection Agency Order 1440.1. U.S. Environmental Protection Agency, July 12, 1981.

NIOSH. 1985. Occupational safety and health guidance manual for hazardous waste site activities. National Institute for Occupational Safety and Health, Occupational Safety and Health Administration, U.S. Coast Guard, and Environmental Protection Agency, DHHS (NIOSH) Publication 85-115, October 1985.

Occupation Health Guidelines for Chemical Hazards, January 1981, Part 1 of 3PB83-154609.

Occupational Health Guidelines for Chemical Hazards, January, 1981, Part 2 of 3PB83-154609.

Occupational Health Guidelines for Chemical Hazards, January 1981, Part 3 of 3PB83-154609. 
MARTIN MARIETTA

ENERGY SYSTEMS, INC.

Oak Ridge National Laboratory
Pollutant Assessments Group

Health and Safety

Procedures Manual
Sect. 11 Rev. 2

Date 6/92

Page 1 of 15

SUBJECT: PERSONNEL PROTECTION-LEVEL B

\section{PERSONNEL PROTECTION_LEVEL B}

\subsection{PURPOSE}

To describe the equipment and procedures required for protection and decontamination of personnel who will perform field activities when the highest level of respiratory protection is needed but hazardous material exposure to the few unprotected parts of the body is not expected.

\subsection{APPLICABIITY}

Protective clothing and equipment must be worn by personnel when field activities involve known or suspected hazardous substances. The procedures described are guidelines for the maximum and minimum amount of decontamination required for Level B protection.

The establishment of decontamination zones is site-specific: the zones are dependent on the types of contamination and the work performed. When the decontamination zone is no longer required, contaminated wash and rinse solutions and articles must be contained and disposed of appropriately. Disposal must be in compliance with installation requirements and any applicable state and federal regulations (Sect. 8.7.1).

\section{PROCEDURES}

\subsubsection{Office}

1. The selection of the appropriate level of personnel decontamination is site specific and must be coordinated with the SSHO or SPM.

Considerations for selection include work activity, known or suspected contaminants, previous experience at the site, and the installation of health and safety requirements specified by the facility management. 


\section{SUBJECT: PERSONNEL PROTECTION-LEVEL B}

2. The site health and safety plan will contain detailed plans for ultimate disposal of protective clothing, wastewater, and potentially contaminated articles. The packaging and disposal plans must be approved by the installation authorities responsible for waste disposal and must comply with Department of Transportation (DOT) regulations. All on-site personnel will be informed of the proper procedures for disposal of protective clothing and decontamination solutions.

3. For maximum measures of Level B protection, Table 11.1 provides equipment recommendations. Level $A$ protection and decontamination procedures will be the same as maximum Level B protection, except that fully encapsulated suits will be donned in place of the chemical-resistant splash suit. Minimal protective equipment guidance is presented in Table 11.2. These measures present general equipment guidance. The selection of equipment must be site-specific in order to incorporate unusual work activities or features and will be detailed in the site sampling plan.

Table 11.1. Maximum equipment recommendations for Level B

Maximum protective equipment

1. Fully encapsulated protective suit

2. Chemical-resistant disposable gloves

3. Nitrile or butyl rubber outer boots

4. SCBA that uses a pressure-demand or positive-pressure air supply system

Additional equipment that may be specified

1. Hard hat

2. Hard-toed boots

3. Safety glasses, goggles, or face shield

4. Escape mask

5. SCBA with air purifying cartridges

6. Full-face air-line-supplied breathing apparatus

7. Safety "tag" rope 
MARTIN MARIETTA

ENERGY SYSTEMS, INC.

Oak Ridge National Laboratory
Pollutant Assessments Group

Health and Safety

Procedures Manual
Sect. 11 Rev. 2

Date 6/92

Page 3 of 15

\section{SUBJECT: PERSONNEL PROTECTION-LEVEL B}

Table 11.2 Minimum equipment recommendations for Level B

\section{Minimum protective equipment}

1. Chemical-resistant polyethylene-lined Tyvek clothing

2. Chemical-resistant disposable gloves

3. Nitrile or butyl rubber outer boots

4. Self-contained breathing apparatus (SCBA) using a pressure demand or positive pressure air supply system

\section{Additional equipment that may be specified}

1. Hard hat

2. Hard-toed boots

3. Safety glasses, goggles, or face shield

4. Escape mask

5. SCBA with air purifying cartridges

6. Full-face air-line-supplied breathing apparatus

7. Safety "tag" rope

8. Fully encapsulated protective suit

\subsubsection{Field}

1. Prior to initiating field activities, site work zones shall be established to reduce the accidental spread of hazardous substances. The establishment of work zones should be site-specific and coordinated with the site's health and safety coordinator at the time the health and safety plan is prepared. Considerations for establishment of work zones shall include wind direction, weather conditions, emergency situations, changes in site activities, access, and egress.

2. Figure 11.1 presents an example of a maximum decontamination layout for Level B protection. An example of the minimal decontamination layout for Level B protection is presented in Fig. 11.2. It is important to note that these examples may be modified according to site-specific conditions. 
MARTIN MARIETTA

ENERGY SYSTEMS, INC.

Oak Ridge National Laboratory
Pollutant Assessments Group

Health and Safety

Procedures Manual
Sect. 11 Rev. 2

Date 6/92

Page 4 of 15

\section{SUBJECT: PERSONNEL PROTECTION-LEVEL B}

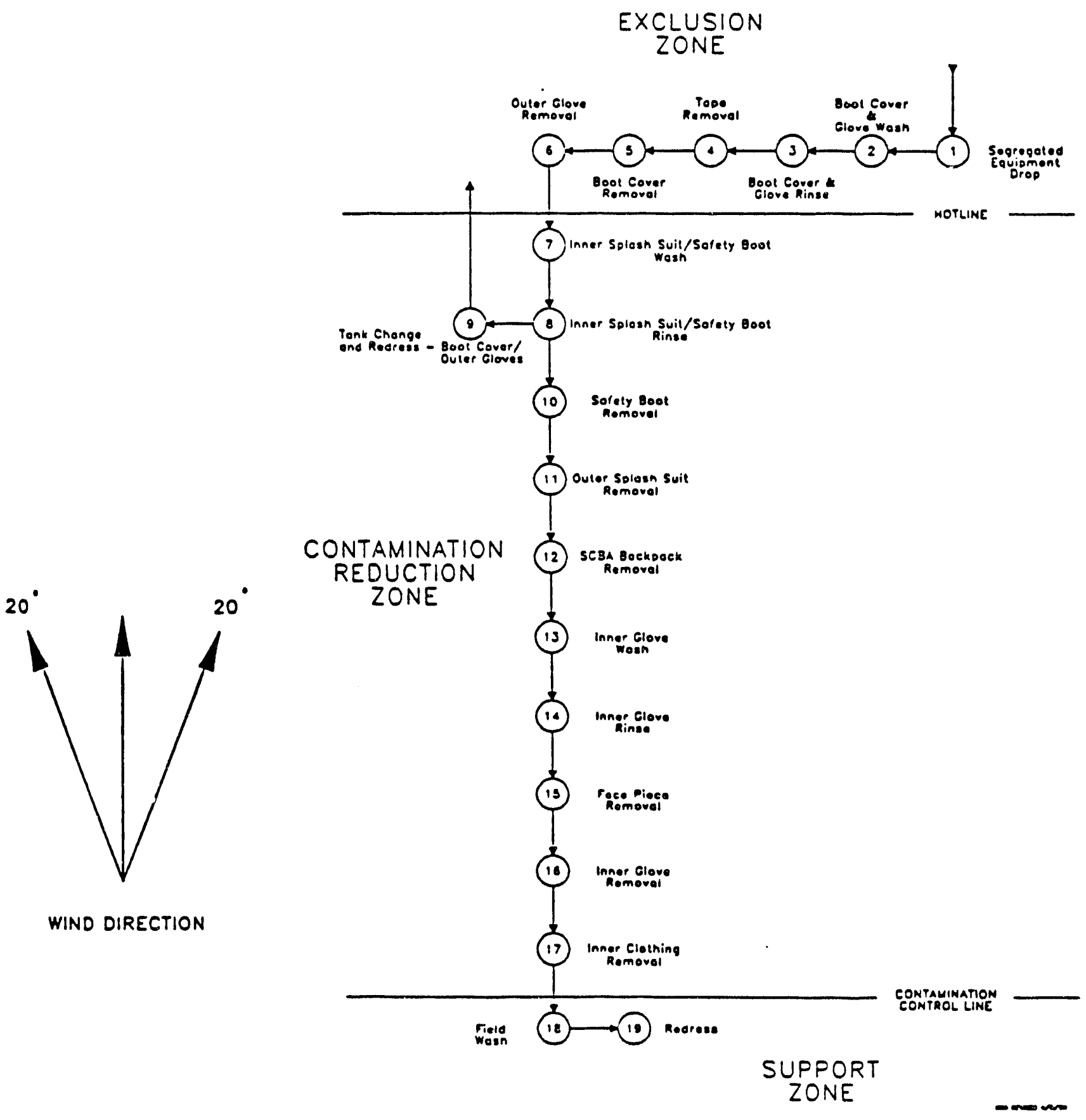

Fig 11.1 Maximum decontamination layout-Level B Protection 
MARTIN MARIETTA

ENERGY SYSTEMS, INC.

Oak Ridge National Laboratory
Pollutant Assessments Group

Health and Safety

Procedures Manual
Sect. 11 Rev. 2

Date $6 / 92$

Page 5 of 15

\section{SUBJECT: PERSONNEL PROTECTION_LEVEL B}

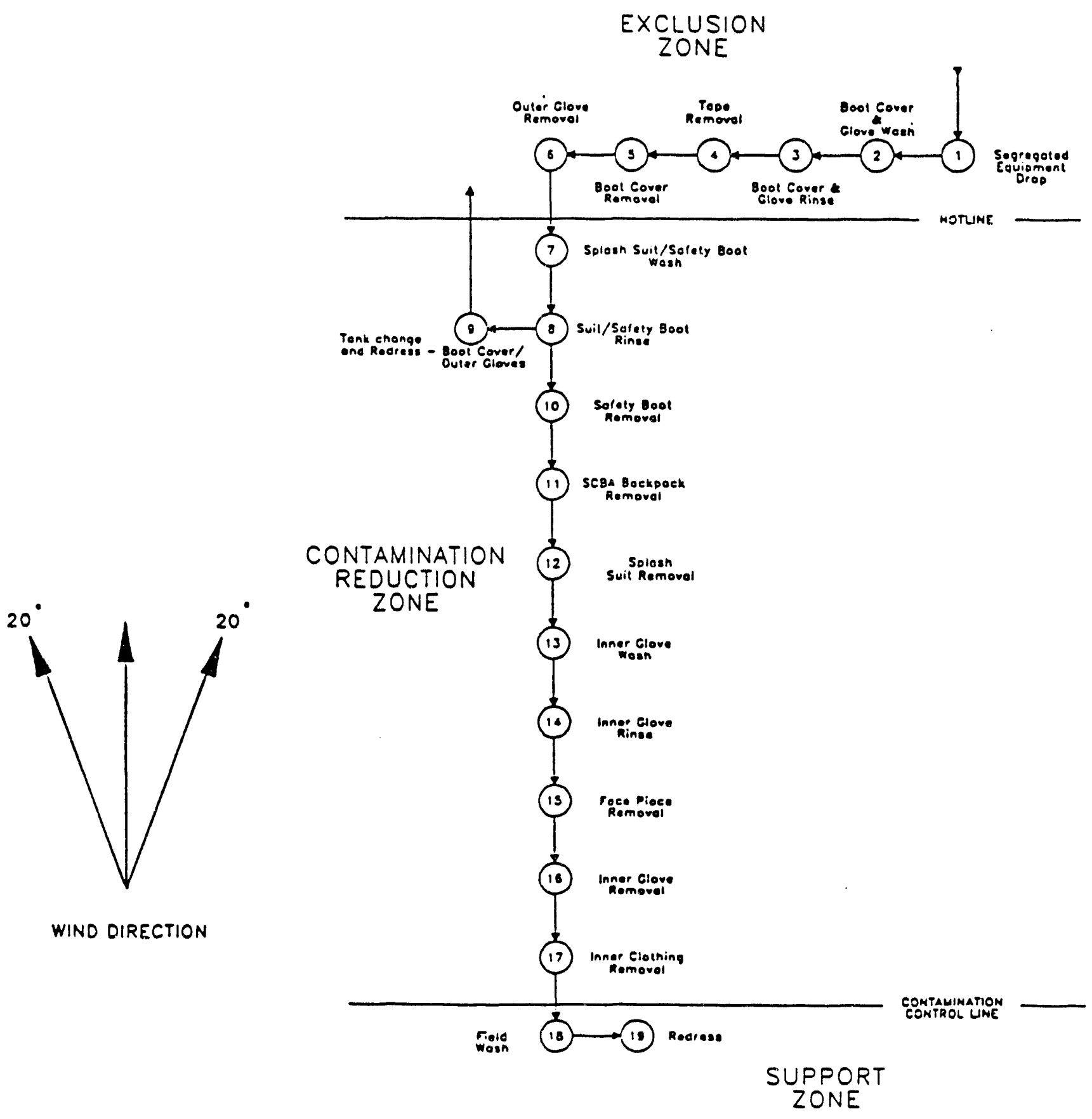

Fig. 112 Minimum decontamination layout-Level B Protection 


\subsection{OPERATION}

\subsubsection{Maximum Decontamination Measures}

The equipment needed to perform maximum decontamination measures for Level B are described in Table 11.3. These measures represent guidelines and may be modified according to site-specific conditions for Level $\mathrm{A}$ or $\mathrm{C}$ protection in areas specifically designated as such. Overprotection can cause hazards such as heat stress, and underprotection can cause hazardous exposure. Maximum decontamination measures are detailed in Table 11.4.

\subsubsection{Modification of Maximum Decontamination Measures}

Depending on site-specific conditions and circumstances, modification of the maximum decontamination measures may be permissible. Two examples of situations in which the maximum decontamination measures may be modified are described in the following.

1. Situation 1-The individual entering the contamination reduction zone is expected to be minimally contaminated. Extremely toxic or skin-corrosive materials are not present. No outer gloves or boot covers are worn. The inner gloves are not contaminated.

The following decontamination stations for Level $\mathrm{B}$, as described in Table 11.4, would be used in this situation: Stations $1,7,8,10,11,12,15,16,17,18$, and 19.

2. Situation 2-The individual entering the contamination reduction zone is expected to be minimally contaminated. Extremely toxic or skin-corrosive materials are not present. No outer gloves or boot covers are worn. The inner gloves are not contaminated. The individual needs a new air tank and will return to the exclusion zone.

The following decontamination stations for Level $\mathrm{B}$, as described in Table 11.4, would be used in this situation: Stations $1,7,8,9$, and 10 . 


\section{SUBJECT: PERSONNEL PROTECTION-LEVEL B}

Table 11.3. Equipment needed to perform maximum decontamination measures for Level B

Station 1: a. Various size containers

b. Plastic trash bags

c. Plastic tarpaulin

Station 2: a. Containers (20-30 gal)

b. Decon solution or detergent water

c. 2 to 3 long-handled, soft-bristled scrub brushes

Station 3: a. Containers (20-30 gal) or high-pressure spray unit

b. Water

c. 2 to 3 long-handled, soft-bristled scrub brushes

Station 4: a. Containers (20-30 gal)

b. Plastic trash bags

Station 5: a. Containers (20-30 gal)

b. Plastic trash bags

c. Bench or stools

Station 6: a. Containers (20-30 gal)

b. Plastic trash bags

Station 7: a. Containers (20-30 gal)

b. Decon solution or detergent water

c. 2 to 3 long-handled, soft-bristled scrub brushes

Station 8: a. Containers (20-30 gal) or high-pressure spray unit

b. Water

c. 2 to 3 long-handled, soft-bristled scrub brushes 
MARTIN MARIETTA

ENERGY SYSTEMS, INC.

Oak Ridge National Laboratory
Pollutant Assessments Group Health and Safety Procedures Manual
Sect. 11 Rev. 2

Date 6/92

Page 8 of 15

\section{SUBJECT: PERSONNEL PROTECTION-LEVEL B}

\section{Table 11.3 (continued)}

Station 9: a. Air tanks or face masks and cartridge depending on level

b. Tape

c. Boot covers

d. Gloves

Station 10: a. Containers (20-30 gal)

b. Plastic trash bags

c. Bench or stools

d. Boot jack

Station 11: a. Rack

b. Tarpaulin

c. Bench or stools

Station 12: a. Table

Station 13: a. Basin or bucket

b. Decon solution

c. Small table

Station 14: a. Water

b. Basin or bucket

c. Small table

Station 15: a. Containers (20-30 gal)

b. Plastic trash bags

Station 16: a. Containers (20-30 gal)

b. Plastic trash bags

Station 17: a. Containers (20-30 gal)

b. Plastic trash bags 


\section{SUBJECT: PERSONNEL PROTECTION_LEVEL B}

Table 11.3 (continued)

Station 18: a. Water

b. Soap

c. Small table

d. Basin or bucket

e. Field showers

f. Towels

Station 19: a. Dressing shelter is needed in inclement weather

b. Tables

c. Chairs

d. Lockers

e. Cloths

Note: In the course of Level A protection, a fully encapsulated suit will be worn in place of a splash suit. A splash suit and boot and glove covers may still be required for additional protection.

Sources: NIOSH 1985. 
MARTIN MARIETTA

ENERGY SYSTEMS, INC.

Oak Ridge National Laboratory
Pollutant Assessments Group

Health and Safety

Procedures Manual
Sect. 11 Rev. 2

Date 6/92

Page 10 of 15

SUBJECT: PERSONNEL PROTECTION-LEVEL B

Table 11.4. Maximum measures for Level B protection and decontamination stations

Station Procedure

Station 1: Segregated equip- Deposit equipment used on-site (tools, sampling ment drop devices and containers, monitoring instruments, radios, clipboards, etc.) on plastic tarpaulins or in designated containers lined with plastic trash bags. Segregation at the drop zone reduces the probability of cross-contamination. During hot weather operations, a cool-down station may be set up within this area

Station 2: Boot cover and glove

Scrub outer boot covers and gloves with wash decontamination solution or detergent and water

Station 3: Boot cover and glove rinse

Rinse off decon solution from Station 2 using copious amounts of water

Station 4: Tape removal

Remove tape around boots and gloves and deposit in container lined with plastic trash bag

Station 5: Boot cover removal

Remove boot covers and deposit in containers lined with plastic trash bag

Station 6: Outer glove removal

Station 7: Suit and safety boot wash

Remove outer gloves and deposit in container lined with plastic trash bag

Wash chemical-resistant splash suit (or fully encapsulated suit if Level A protection was used), SCBA, gloves, and safety boots. Scrub with long-handled scrub brush and decontamination solution. Wrap SCBA regulator (if mounted-belt type) with plastic to keep water out. Wash bact.pack assembly with sponges or cloths

Station 8: $\quad$ Suit, SCBA, boot, and glove rinse

Rinse off decontamination solution using copious amounts of water

Station 9: Tank change

If worker leaves exclusion zone to change air tank, this is the last step in the decontamination procedure. Worker's air tank is exchanged, new outer gloves and boot covers donned, and joints taped. Worker returns to duty 
MARTIN MARIETTA

ENERGY SYSTEMS, INC.

Oak Ridge National Laboratory
Pollutant Assessments Group

Health and Safety

Procedures Manual
Sect. 11 Rev. 2

Date 6/92

Page 11 of 15

SUBJECT: PERSONNEL PROTECTION-LEVEL B

Table 11.4 (continued)

\begin{tabular}{|c|c|c|}
\hline & Station & Procedure \\
\hline Station 10: & Safety boot removal & $\begin{array}{l}\text { Remove safety boots and deposit in container } \\
\text { lined with plastic trash bag }\end{array}$ \\
\hline Station 11: & $\begin{array}{l}\text { SCBA backpack } \\
\text { removal }\end{array}$ & $\begin{array}{l}\text { While still wearing facepiece, remove backpack } \\
\text { and place on table. Disconnect hose from } \\
\text { regulator valve }\end{array}$ \\
\hline Station 12: & Splash suit removal & $\begin{array}{l}\text { With assistance of helper, remove splash suit. } \\
\text { Deposit in container lined with plastic trash bag }\end{array}$ \\
\hline Station 13: & Inner glove wash & Wash inner gloves with decontamination solution \\
\hline Station 14: & Inner glove rinse & Rinse inner gloves with water \\
\hline Station 15: & Face piece removal & $\begin{array}{l}\text { Remove facepiece. Deposit in container lined } \\
\text { with plastic trash bag. Avoid touching face with } \\
\text { fingers }\end{array}$ \\
\hline Station 16: & Inner glove removal & $\begin{array}{l}\text { Remove inner gloves and deposit in container } \\
\text { lined with plastic trash bag }\end{array}$ \\
\hline Station 17: & $\begin{array}{l}\text { Inner clothing } \\
\text { removal }\end{array}$ & $\begin{array}{l}\text { Remove inner clothing. Place in container lined } \\
\text { with plastic trash bag. Do not wear clothing } \\
\text { off-site since there is a possibility that small } \\
\text { amounts of contaminants might have been } \\
\text { transferred while removing the outer clothing }\end{array}$ \\
\hline Station 18: & Field wash & $\begin{array}{l}\text { Shower if highly toxic, skin-corrosive, or } \\
\text { skin-absorbable materials are known or suspected } \\
\text { to be present. Wash hands and face if shower is } \\
\text { not available }\end{array}$ \\
\hline Station 19: & Re-dress & Put on clean clothes \\
\hline
\end{tabular}

Note: Personnel performing tasks in Level A protective equipment will sequentilly proceed through all of the decontamination stations for verification purposes.

Sources: NIOSH 1985. 
MARTIN MARIETTA

ENERGY SYSTEMS, INC.

Oak Ridge National Laboratory
Pollutant Assessments Group

Health and Safety

Procedures Manual
Sect. 11 Rev. 2

Date 6/92

Page 12 of 15

\section{SUBJECT: PERSONNEL PROTECTION-LEVEL B}

\subsubsection{Minimum Decontamination Measures}

The equipment needed to perform minimum decontamination measures for Level B are described in Table 11.5. These measures also present guidelines only and may be modified according to site-specific conditions. Decontamination measures for minimum Level B protection requirements are detailed in Table 11.6.

\subsection{POSTOPERATION}

\subsubsection{Field}

At the completion of field activities, all contaminated wash and rinse water, decontamination solutions, and contaminated articles must be properly disposed of as detailed in Sect. 8.7.1. The disposal must comply with installation requirements and any applicable state and federal regulations. The SPM is responsible for the safe disposal of contaminated materials. Planning for proper disposal should be included during office preparations prior to field activities.

\section{5 .2 Office}

All unused and/or properly decontaminated equipment should be returned to the designated storage facilities. The procurement coordinator should be apprised of all stock items that need to be ordered to replenish the inventory. 


\section{SUBJECT: PERSONNEL PROTECTION-LEVEL B}

Table 11.5. Equipment needed to perform minimum decontamination measures for Level B

Station 1: a. Various size containers

b. Plastic trash bags

c. Plastic drop cloths

Station 2: a. Containers (20-30 gal)

b. Decon solution

c. Rinse water

d. 2 to 3 long-handled, soft-bristled scrub brushes

Station 3: a. Containers (20-30 gal)

b. Plastic trash bags

c. Bench or stools

Station 4: a. Air tanks or masks and cartridges depending upon types of contaminants

b. Tape

c. Boot covers

d. Gloves

Station 5: a. Containers (20-30 gals)

b. Plastic trash bags

c. Bench or stools

Station 6: a. Plastic tarp

b. Basin or bucket

c. Soap

d. Towels

e. Bench or stools

Station 7: a. Water

b. Soap

c. Tables

d. Wash basin or bucket

Sources: NIOSH 1985. 
SUBJECT: PERSONNEL PROTECTION-LEVEL B

Table 11.6. Minimum measures for Level B decontamination stations

\begin{tabular}{lll}
\hline & \multicolumn{1}{c}{ Task } & \multicolumn{1}{c}{ Procedure } \\
\hline Station 1 & Equipment drop & $\begin{array}{l}\text { Deposit equipment used on-site (tools, sampling } \\
\text { devices and containers, monitoring instruments, } \\
\end{array}$ \\
& radios, clipboards, etc.) on plastic drop \\
& tarpaulin. Segregation at the equipment drop \\
& reduces the probability of cross-contamination. \\
& During hot weather operations, a cool-down \\
& station may be set up within this area
\end{tabular}

Station 2 Outer garment, boot, and glove wash and rinse

Station 3 Outer boot and glove removal

Station 4 Tank change

Station 5 Boot, glove and outer garment removal

Station 6 SCBA removal

Station 7 Field wash
Scrub outer boots, outer gloves, and splash suit with decon solution or detergent water. Rinse off using water

Remove outer boots and gloves, deposit in container lined with plastic trash bag

If worker leaves exclusive zone to change air tank, this is the last step in the decontamination procedures. Worker's air tank is exchanged, new outer gloves and boot covers donned, joints taped; worker returns to duty

Boots, chemical-resistant splash suit and inner gloves are removed and deposited in separate containers lined with plastic trash bags

SCBA backpack and face piece is removed. Avoid touching face with fingers. SCBA deposited on plastic tarpaulin

Hands and face are thoroughly washed. Shower as soon as possible

Sources:NIOSH 1985. 
MARTIN MARIETTA

ENERGY SYSTEMS, INC.

Oak Ridge National Laboratory
Pollutant Assessments Group

Health and Safety

Procedures Manual
Sect. 11 Rev. 2

Date 6/92

Page 15 of 15

SUBJECT: PERSONNEL PROTECTION-LEVEL B

\subsection{REFERENCES}

Code of Federal Regulations-29, Pt. 1900-1910, 7/87.

Code of Federal Regulations-30, Pt. 1-199, 1986.DOE. 1985. Comprehensive

Environmental Response, Compensation, and Liability Act Program. DOE Order 5480.14. U.S. Department of Energy, Washington, D.C.

Doull, J., Klaasen, C. D., and Amdur, M. O. 1986. Casarett and Doull's Toxicology, Macmillan, New York.

EPA. 1981. Health and safety requirements for employees engaged in field activities. Environmental Protection Agency Order 1440.1. U.S.Environmental Protection Agency, July 12, 1981.

NIOSH. 1985. Occupational safety and health guidance manual for hazardous waste site activities. National Institute for Occupational Safety and Health, Occupational Safety and Health Administration, U.S. Coast Guard, and Environmental Protection Agency, DHHS (NIOSH) Pub. No. 95-115, October.

Occupation Health Guidelines for Chemical Hazards, January 1981, Part 1 of 3PB83-154609.

Occupational Health Guidelines for Chemical Hazards, January, 1981, Part 2 of 3-PB83-154609.

Occupational Health Guidelines for Chemical Hazards, January 1981, Part 3 of 3-PB83-154609. 
MARTIN MARIETTA

ENERGY SYSTEMS, INC.

Oak Ridge National Laboratory
Pollutant Assessments Group

Health and Safety

Procedures Manual
Sect. 12 Rev. 2

Date 6/92

Page 1 of 9

SUBJECT: PERSONNEL PROTECTION-LEVEL A

\section{PERSONNEL PROTECTION-LEVEL A}

\subsection{PURPOSE}

To describe the equipment and procedures required for protection and decontamination of personnel who will perform field activities when the maximum respiratory, eye, and skin protection is required.

\section{APPLICABILTY}

Protective clothing and equipment must be worn by personnel when field activities involve known or suspected hazardous substances. The procedures described are guidelines for the required amount of personnel protection required for Level $\mathrm{A}$. If dermal exposure is proven to be not hazardous, then Level $B$ protective measures will be instituted.

The establishment of decontamination zones is site specific; these zones are dependent on the types of contamination and the work performed. When the decontamination zone is no longer required, contaminated wash and rinse solutions and articles must be contained and disposed of appropriately. Disposal must be in compliance with installation requirements and any applicable state and federal regulations (Sect. 8.7.1).

\section{PROCEDURES}

\subsection{Office}

1. The selection of the appropriate level of personnel decontamination is site specific and must be coordinated with the SSHO and SPM. Considerations for selection include work activity, known or suspected contaminants, previous experience at the site, and the installation of health and safety requirements specified by the facility management.

\section{APPROVED BY:}


MARTIN MARIETTA

ENERGY SYSTEMS, INC.

Oak Ridge Nátional Laboratory
Pollutant Assessments Group

Health and Safety

Procedures Manual
Sect. 12 Rev. 2

Date 6/92

Page 2 of 9

SUBJECT: PERSONNEL PROTECTION-LEVEL A

2. The site health and safety plan will contain details of the plans for ultimate disposal of protective clothing, wastewater, and potentially contaminated articles. The packaging and disposal plans must be approved by the installation authorities responsible for waste disposal. All on-site personnel will be informed of the proper disposal of protective clothing and decontamination solutions.

\subsection{Field}

1. Prior to initiating field activities, site work zones shall be established to reduce the accidental spread of hazardous substances. The establishment of work zones should be site specific and coordinated with all of the personnel directly associated with the site investigation at the time the site is first investigated. Considerations for establishment of work zones shall include wind direction, weather conditions, emergency situations, changes in site activities, access, and egress.

2. Table 12.1 provides guidance on Level A equipment recommendations. Level A protection and decontamination procedures will be modified only if more protection is required. Equipment needed to perform Level A decontamination is listed in Table 12.2. Decontamination measures for equipment and personnel is listed in Table 12.3 .

3. Figure 12.1 presents an example of a decontamination layout for Level $\mathbf{A}$ protection. It is important to note that these examples may be modified according to site-specific conditions so that the proper material for encapsulated suits, outer gloves, overboots, and other protective apparel are can be selected. Decontamination procedures will also vary on a case-by-case basis, depending on physical and chemical properties of suspected contaminants. 
MARTIN MARIETTA

ENERGY SYSTEMS, INC.

Oak Ridge National Laboratory
Pollutant Assessments Group

Health and Safety

Procedures Manual
Sect. 12 Rev. 2

Date 6/92

Page 3 of 9

\section{SUBJECT: PERSONNEL PROTECTION_LEVEL A}

Table 12.1. Equipment recommended for Level A protection

1. Chemical-resistant fully encapsulated suit

2. Chemical-resistant disposable inner gloves

3. Chemical-resistant outer boots

4. SCBA with full facepiece that uses a supplied-air positive-pressure system

5. Two-way radio communication

6. 10-min escape SCBA

Additional equipment that may be specified

1. Hard hat

2. Hard-toed boots

3. Face shield

4. 10-min SCBA escape mask

5. SCBA

6. Full-face air-line-supplied breathing apparatus with a back-up SCBA escape mask

7. Safety rope

8. Tyvek clothing, which may be worn over the fully encapsulated suit for additional protection

9. Additional gloves and over-boots

10. Anti-fog solution for full-face mask

11. Cooling unit

12. Coveralls

13. Cotton long underwear 


\section{SUBJECT: PERSONNEL PROTECTION-LEVEL A}

Table 122 Equipment needed to perform decontamination measures for Level $A$

Station 1:
a. 2 tables
b. Plastic liners
c. Plastic drop cloths

Station 2:
a. 2 containers (20-30 gal)
b. Decontamination solution or detergent water
c. 2 long-handled, soft-bristled scrub brushes

Station 3: a. Containers (20-30 gal) or high-pressure spray unit

b. Water

c. 2 long-handled, soft-bristled scrub brushes

Station 4:
a. Containers $(20-30 \mathrm{gal})$
b. Plastic liners

Station 5:
a. Containers (20-30 gal)
b. Plastic liners
c. Bench or stools

Station 6:
a. Containers $(20-30 \mathrm{gal})$
b. Plastic liners

Station 7:
a. Containers (20-30 gal)
b. Decon solution or detergent water
c. 2 long-handled, soft-bristled scrub brushes

Station 8: a. Containers (20-30 gal) or high-pressure spray unit

b. Water

c. 2 long-handled, soft-bristled scrub brushes

Station 9: a. Air tanks or face masks and air line
b. Tape
c. Boot covers
d. Gloves

Station 10: a. Containers (20-30 gal)

b. Plastic liners

c. Bench or stools

d. Bout jack

Station 11: a. Rack

b. Drop cloths

c. Bench or stools 
MARTIN MARIETTA

ENERGY SYSTEMS, INC.

Oak Ridge National Laboratory
Pollutant Assessments Group

Health and Safety

Procedures Manual
Sect. 12 Rev. 2

Date 6/92

Page 5 of 9

SUBJECT: PERSONNEL PROTECTION-LEVEL A

Table 122 (continued)

Station 12: a. Table

Station 13: a. Basin or bucket

b. Decon solution

c. Small table

Station 14: a. Water

b. Basin or bucket

c. Small table

Station 15: a. Containers (20-30 gal)

b. Plastic liners

Station 16: a. Containers (20-30 gal)

b. Plastic liners

Station 17: a. Containers (20-30 gal)

b. Plastic liners

Station 18: a. Water

b. Soap

c. Small table

d. Basin or bucket

e. Field showers

f. Towels

Station 19: a. Dressing trailer is needed in inclement weather

b. Tables

c. Chairs

d. Lockers

e. Cloths

Sources: NIOSH 1985. 


\section{SUBJECT: PERSONNEL PROTECTION-LEVEL A}

Table 123. Measures for Level A decontamination stations

$\frac{\text { Station }}{\text { Station 1: Segregated equipment drop }}$

Station 2: Boot cover and glove wash

Station 3: Boot cover and glove rinse

Station 4: Tape removal

Station 5: Boot cover removal

Station 6: Suit, SCBA, safety boot, and glove wash

Station 7: Suit, SCBA, boot, and glove rinse

Station 8: Outer glove removal
Procedure

Deposit equipment used on-site (tools, sampling devices and containers, monitoring instruments, radios, clipboards, etc.) on tables covered with plastic tarpaulins or in designated containers lined with plastic trash bags. Segregation at the drop zone reduces the probability of cross-contamination. During hot weather operations, a cool-down station may be set up within this area

Scrub outer boot covers and gloves with decon solution or detergent and water

Rinse off decon solution from Station 2 using copious amounts of water

Remove tape around boots and gloves and deposit in container lined with plastic trash bag

Remove boot covers and deposit in containers lined with plastic trash bag

Wash chemical-resistant splash suit and/or fully encapsulated suit, SCBA, gloves and safety boots. Scrub with long-handled scrub brush and decon solution. Wrap SCBA regulator (if belt-mounted type) with plastic to keep water out. Wash backpack assembly with sponges or cloth

Rinse off decontamination solution using adequate amounts of water

Remove outer gloves and deposit in container lined with plastic trash bag 
MARTIN MARIETTA

ENERGY SYSTEMS, INC.

Oak Ridge National Laboratory
Pollutant Assessments Group

Health and Safety

Procedures Manual
Sect. 12 Rev. 2

Date 6/92

Page 7 of 9

SUBJECT: PERSONNEL PROTECTION-LEVEL A

Table 123 (continued)

\begin{tabular}{lll} 
& Station & Procedure \\
\hline Station 9: & Tank change & If worker leaves exclusion zone to change
\end{tabular}

air tank, this is the last step in the decontamination procedure. Worker's air tank is exchanged; new or decontaminated fully encapsulated suit, outer gloves, and boot covers donned; and joints taped. Worker returns to duty

Station 10: Safety boot removal

Station 11: SCBA backpack removal

Station 12: Splash suit removal

Station 13: Inner glove wash

Station 14: Inner glove rinse

Station 15: Face piece removal

Station 16: Inner glove removal

Station 17: Inner clothing removal
Remove safety boots and deposit in container lined with plastic trash bag

While still wearing facepiece, remove backpack and place on table. Disconnect hose from regulator valve.

With assistance of helper, remove splash suit. Deposit in container lined with plastic trash bag

Wash inner gloves with decon solution

Rinse inner gloves with water

Remove facepiece. Deposit in container lined with plastic trash bag. Avoid touching face with fingers

Remove inner gloves and deposit in container lined with plastic trash bag

Remove inner clothing. Place in plastic bag. Do not wear inner clothing off-site if there is a possibility that small amounts of contaminants might have been transferred in removing the outer clothing. Male and female change booths should be erected at this station with a change of clothes provided if necessary 
MARTIN MARIETTA ENERGY SYSTEMS, INC.

Oak Ridge National Laboratory
Pollutant Assessments Group

Health and Safety

Procedures Manual
Sect. 12 Rev. 2

Date 6/92

Page 8 of 9

SUBJECT: PERSONNEL PROTECTION-LEVEL A

Table 123 (continued)

\begin{tabular}{lll}
\hline & Station & \multicolumn{1}{c}{ Procedure } \\
\hline Station 18: & Field wash & $\begin{array}{l}\text { Shower if highly toxic, skin-corrosive, or } \\
\text { skin absorbable materials are known or } \\
\text { suspected to be present. Wash hands and } \\
\text { face if shower is not available }\end{array}$ \\
& & Put on clean clothes \\
\hline
\end{tabular}

Note: Personnel performing tasks in Level A protective equipment will sequentially proceed through all of the decontamination stations as performed in Level B decontamination for ease of duplication.

Sources: NIOSH 1985.

\section{REFERENCES}

Code of Federal Regulations-29, Pt. 1900-1910, 8/87.

Code of Federal Regulations-30, Pt. 1-199, 1986.

DOE. 1985. Comprehensive Environmental Response, Compensation, and Liability Act Program. DOE Order 5480.14. U.S. Department of Energy, Washington, D.C. Doull, J., Klaasen, C. D., and Amdur, M. O. 1986. Casarett and Doull's Toxicology, Macmillan, New York.

EPA. 1981. Health and safety requirements for employees engaged in field activities. Environmental Protection Agency Order 1440.1. U.S. Environmental Protection Agency, July 12, 1981.

NIOSH. 1985. Occupational safety and health guidance manual for hazardous waste site activities. National Institute for Occupational Safety and Health, Occupational Safety and Health Administration, U.S. Coast Guard, and Environmental Protection Agency, DHHS (NIOSH) Publication 85-115, October 1985.

Occupation Health Guidelines for Chemical Hazards, January 1981, Part 1 of 3PB83-154609.

Occupational Health Guidelines for Chemical Hazards, January, 1981, Part 2 of 3-PB83-154609.

Occupational Health Guidelines for Chemical Hazards, January 1981, Part 3 of 3PB83-154609. 
MARTIN MARIETTA

ENERGY SYSTEMS, INC.

Oak Ridge National Laboratory
Pollutant Assessments Group

Health and Safety

Procedures Manual
Sect. 12 Rev. 2

Date 6/92

Page 9 of 9

\section{SUBJECT: PERSONNEL PROTECTION-LEVEL A}

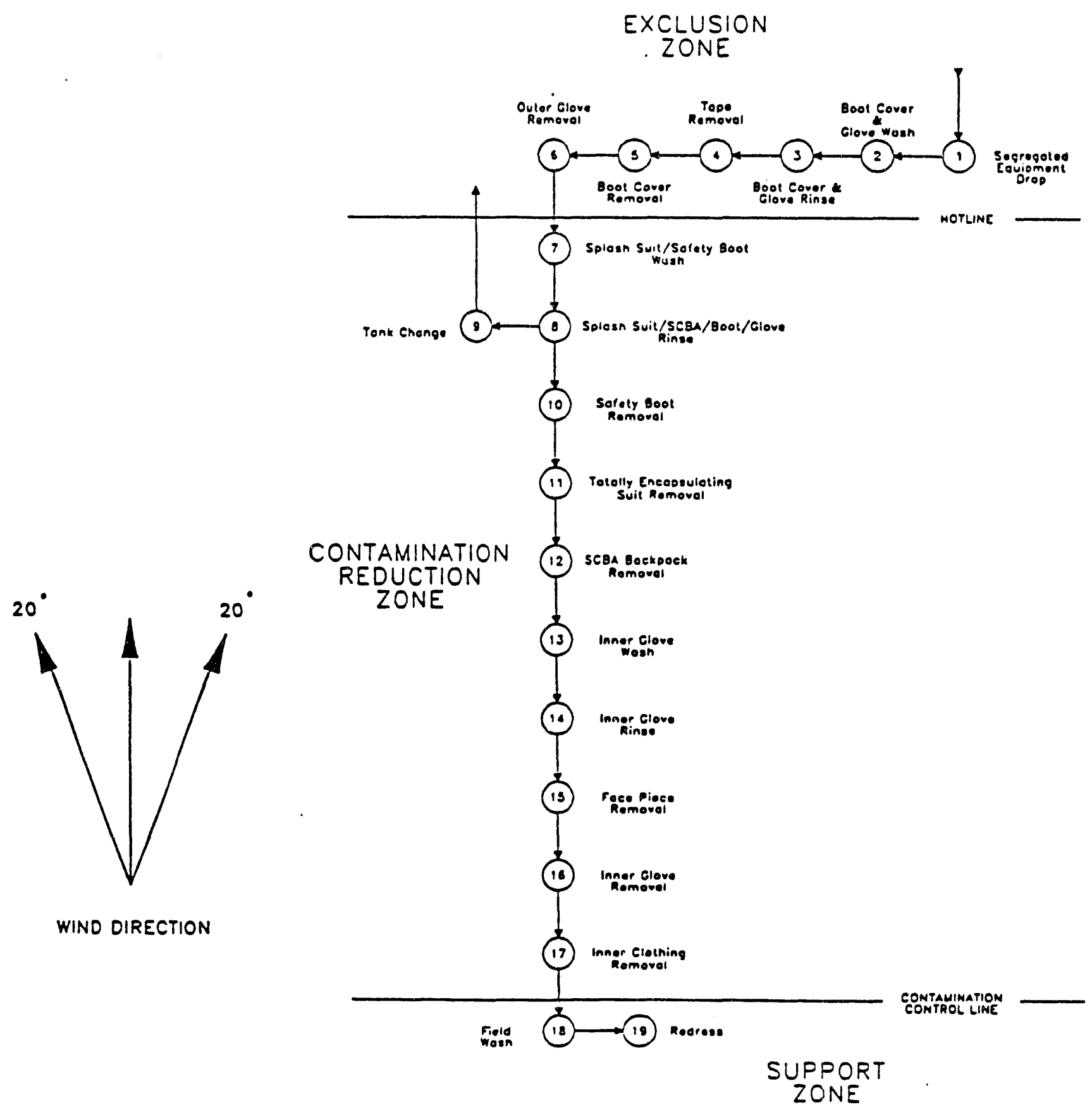

Fig. 121. Decontamination layout-Level A protection 


\section{SUBJECT: SAMPLING AND DRILLING SAFETY PROCEDURES}

\section{SAMPLING AND DRILLING SAFETY PROCEDURES}

\subsection{PURPOSE}

This procedure outlines the safety practices required when drilling and sampling at hazardous waste sites. It establishes general personnel guidelines and responsibilities to ensure that

1. Planning of well installation and sampling include all applicable health and safety objectives.

2. Personnel exposure to hazardous waste, radiation contamination, or other potentially harmful substances is kept as low as reasonably achievable.

\subsection{APPLICABIITY}

This procedure applies to all drilling and sampling activities at hazardous waste sites and may be supplemented by site-specific safety practices. All activities will be conducted in full compliance with applicable federal, state, and ORNL requirements, procedures, and practices. Sampling and drilling operations may include the following:

1. hand auger, posthole, and portable soil-gas sampling systems for collection of surface and near-surface samples;

2. truck or air-track mounted core drilling and split-barrel danger-sampling rigs to collect surface and subsurface soil samples and to install shallow alluvial wells;

3. rotary drilling to install deep soil and water monitoring wells;

4. water and sediment sampling; and

5. drum and tank sampling. 
MARTIN MARIETTA

ENERGY SYSTEMS, INC.

Oak Ridge National Laboratory
Pollutant Assessments Group

Health and Safety

Procedures Manual
Sect. 13 Rev. 2

Date $6 / 92$

Page 2 of 12

SUBJECT: SAMPLING AND DRILLING SAFETY PROCEDURES

\subsection{EQUIPMENT AND MATERIALS}

- Field logbook

- Site-specific health and safety plan and statement of work

- Air monitoring equipment

- Radiation monitoring equipment

- Hard hats

- Safety glasses

- Steel-toed boots

- Hearing protection

- Safety belt (for climbing)

- Gloves

- Spill absorbent

- Chocks

- Dosimeter badges

- Plastic cover for ground

\subsection{RESPONSIBIIITIES}

1. It is the responsibility of all ORNL and subcontracted personnel involved with drilling and sampling operations to strictly adhere to these health and safety procedures at all hazardous waste site operations.

2. Additional responsibility of all personnel involved in drilling and sampling operations are to

- take all reasonable precautions to prevent injury to themselves and to their fellow employees,

- perform only those tasks that they can do safely,

- report immediately any accidents and/or potentially unsafe conditions, and

- notify co-workers and the SSHO of any special hazards.

3. The responsibilities of the SSHO are

- to identify potential hazards of the project and provide measures that will protect workers, the general public, and the environment;

- to determine monitoring requirements for chemical and physical hazards that may be encountered during drilling or sampling, select appropriate monitoring instrumentation, and provide monitoring support;

- to assist in the disposition of all chemically and/or radiologically contaminated materials generated at drilling sites;

- to coordinate occupational safety surveillance of well-drilling operations; 
MARTIN MARIETTA

ENERGY SYSTEMS, INC.

Oak Ridge National Laboratory
Pollutant Assessments Group

Health and Safety

Procedures Manual
Sect. 13 Rev. 2

Date $6 / 92$

Page 3 of 12

\section{SUBJECT: SAMPLING AND DRILLING SAFETY PROCEDURES}

- to issue dosimeter badges if required for external radiation monitoring of personnel;

- to advise personhel on requirements for containment of contaminated material, contamination control, and handling of contaminated tools and equipment;

- to advise personnel on PPE needed at work sites, and if required, provide this protective equipment and training in its proper use;

- to recommend, approve, calibrate, and monitor all field instruments used for environmental surveillance;

- to provide site hazard training for drill crews including:

- fundamentals of personnel protection and control;

- spill prevention, control, and cleanup;

- emergency procedures;

- zoning regulations; and

- other health, safety, and environmental protection procedures;

- to ensure that a safety review is performed and a safety assessment prepared for each well-drilling project that includes:

- ensuring that all potential safety hazards are addressed, including those specific to individual sites;

- specifying measures for controlling potential accident situations;

- identifying potential radiological and chemical hazards that may be encountered at individual sites; and

- confirming with all personnel involved that the site safety plan is properly endorsed, approved, and distributed before well-drilling operations are initiated;

- to approve the type of protective clothing that will be used; arrange for appropriate segregation, packaging, labeling, and disposition of used protective clothing; and ensure that laundering or disposal of all protective clothing is performed properly;

- to ensure that all hazardous exposure incidents are recorded for each individual; and

- to confirm the following at radiological investigation sites:

- that all personnel are provided with radiation monitoring devices, the monitors are used correctly, and the monitoring devices are returned for processing;

- that drill crew members are available to whole-body counting if warranted;

- that individuals suspected of having accidentally sustained an intake of radioactive materials are given a whole-body count as soon after the occurrence as feasible; and

- that site personnel without personal radiation monitoring devices will be documented and that radiation exposures concurrent with personnel 
MARTIN MARIETTA

ENERGY SYSTEMS, INC.

Oak Ridge National Laboratory
Pollutant Assessments Group

Health and Safery

Procedures Manual
Sect. 13 Rev. 2

Date 6/92

Page 4 of 12

SUBJECT: SAMPLING AND DRILLING SAFETY PROCEDURES

performing the same or similar tasks at the specific site of concern will be assumed.

\subsection{DEFINITIONS}

Auger: a drilling device that continuously removes cuttings from the bottom of the hole during drilling, without the use of fluids.

Auger flights: the winding metal cutting edges of the auger that carry cuttings to the surface during drilling; alternatively, a section of auger itself.

Auger fork: a U-shaped flat metal piece with a welded handle that is placed between auger flights at ground level to prevent the auger from falling into the borehole; also called a slip or skillet.

Blind ram: an integral part of a blowout preventer that serves as the closing element. Its ends do not fit around the drill pipe but seal against each other and shut off the space below completely.

Blowout preventer: one of several valves installed at the wellhead to prevent the escape of pressure either in the annular space between the casing and drill pipe or in an open hole (i.e., hole with no drill pipe) during drilling or completion operations. Blowout preventers are located beneath the rig at ground surface.

Cathead: a spool-shaped attachment on a winch around which rope (the catline) for hoisting and pulling is wound.

Catline: a hoisting or pulling line made of rope not less than 1 in. in diameter and powered by the cathead; used to lift heavy equipment on the rig.

Chock a wedge used to block tires to keep equipment from moving accidentally.

Drill stem: all parts in the assembly used for drilling from the swivel to the bit, including the kelly, drill pipe/rods, augers, and bit.

Kill switch: a safety switch used to turn off the drill rig in an emergency.

Mast: a portable derrick capable of being erected as one unit as opposed to a derrick that cannot be raised to a working position as a unit.

PPE: personal protective equipment. 
MARTIN MARIETTA

ENERGY SYSTEMS, INC.

Oak Ridge National Laboratory
Pollutant Assessments Group

Health and Safety

Procedures Manual
Sect. 13 Rev. 2

Date 6/92

Page 5 of 12

\section{SUBJECT: SAMPLING AND DRILLING SAFETY PROCEDURES}

Ram: the closing and sealing component on a blowout preventer. One of three types-blind, pipe, or shear-may be installed in several preventers mounted in a stack on top of the wellbore. Blind rams, when closed, form a seal on a hole that has no drill pipe in it; pipe rams, when closed, seal around the pipe; shear rams cut through drill pipe and then form a seal.

Traveling block: an arrangement of pulleys or sheaves through which drilling cable is reeved and that moves up and down in the derrick or mast.

\subsection{PROCEDURES}

1. When decontaminating equipment, use adequate eye and skin protection while working with or near high-pressure, hot-water, or steam-cleaning equipment.

2. Inspect drilling unit.

- During overhead drill rig repair, drill crew should keep personnel away form the rig.

- Check drill rig for oil and fuel leaks. If leaks are located, either replace connections and hoses or containerize fluids so that they will not interfere with drilling or contaminate ground surface.

- Inspect guards on moving parts.

- Inspect catline for wear, grease, and unsafe conditions.

- Never ride catline, cable pulley (traveling) blocks, or any suspended equipment as a means to ascend or descend mast.

- Do not climb on catline.

- Replace or repair grooved, worn, or damaged cathead.

- Do not use wire rope on cathead.

- Use cathead only with loads requiring three wraps or less.

- Do not leave catline wrapped around cathead or in contact with cathead when not in use; coil neatly out of way.

- Do not allow overlays of rope lays.

- When manually operating a rope or line on the cathead, have an experienced employee at the kill switch to stop rotation of cathead promptly in case of emergency.

- Visually inspect wire rope daily.

- The driller should thoroughly inspect wire rope at a minimum of 30-day intervals.

- Inspect nonrotating rope carefully. 
MARTIN MARIETTA

ENERGY SYSTEMS, INC.

Oak Ridge National Laboratory
Pollutant Assessments Group

Health and Safety

Procedures Manual
Sect. 13 Rev. 2

Date $6 / 92$

Page 6 of 12

\section{SUBJECT: SAMPLING AND DRILLING SAFETY PROCEDURES}

- Record wire rope inspection in the daily drilling log. Note any deterioration that may result in appreciable loss of original strength such as:

- reduction of rope diameter below nominal diameter resulting from loss of core support, internal or external corrosion, or wear of outside wires;

- broken outside wires and the distribution or concentration of such broken wires;

- corroded or broken wires at end connections;

- corroded, cracked, bent, worn, or improperly applied end connections; and severe kinking, crushing, cutting, or unraveling.

- Store and maintain wire rope carefully and replace when necessary.

- Unreel or uncoil rope according to manufacturer's recommendations to avoid kinking or twisting.

- Prevent unlaying of wire strands during cutting by securing rope in the vicinity of the cut.

- During installation, avoid dragging the rope in dirt or around objects that might scrape, nick, crush, or induce sharp bends.

- Replace rope when any of the following occur:

- six randomly distributed broken wires in one rope lay or broken wires in one strand in one rope lay;

0 wear of one-third the original diameter of outside individual wires; and

- kinking, crushing, unraveling, or any other damage resulting in distortion of the rope structure.

- Record reason for replacement in drilling logbook.

- Replace with rope of the same size, grade, and construction unless otherwise instructed by the rope manufacturer due to actual working-condition requirements.

- Inspect all chains, hooks, boomers, clamps, and tensioning devices that are used with the winch line.

- These must all have as much strength as the winch line.

- Determine that the winch line hook is properly secured with U-bolt clamps of proper size or their equivalent.

- Do not weld any hoisting tools in the field. This could reduce the tool strength and create a safety hazard.

- Remove safety clamps from drill collars, pipes, or similar equipment before hoisting.

- Connect and maintain hooks in the following ways:

- Connect hooks across the chain, not with the end inside of the chain link.

- Repair nicks and gouges by grinding longitudinally, following the contour of the hook.

- When grinding, do not reduce any dimension below $10 \%$ of its original value. 
MARTIN MARIETTA

ENERGY SYSTEMS, INC.

Oak Ridge National Laboratory
Pollutant Assessments Group

Health and Safety

Procedures Manual
Sect. 13 Rev. 2

Date $6 / 92$

Page 7 of 12

\section{SUBJECT: SAMPLING AND DRILLING SAFETY PROCEDURES}

- All other repairs would be made by the manufacturer or other qualified person.

- Determine that blowout preventer equipment is adequate and of the proper design.

- This equipment should be rated in accordance with the site-specific drilling program and the pressure tolerance limits of the circulation equipment used.

- This equipment should be present on wells where formation pressure is known or suspected to be hazardous and should consist of at least one blowout preventer with pipe rams, blind rams, and valving to permit fluid circulation at the surface.

- Secure all pressure-hose connections with safety chains or clamps to prevent whipping in the event of a break.

- Make certain that pipe, drill stems, rods, or other materials will not fall from a storage rack or form the mast.

- Check kill switch(es) to determine working condition.

- KNOW THE LOCATION OF THE KILL SWITCH.

2. Safety position and level the drill unit on preselected site.

- Never move the drill rig with mast extended vertically.

- Check with site personnel for written confirmation that all utilities at drilling locations have been delineated.

- This utility clearance includes but is not limited to clearance of overhead and buried gas, electrical, water, sewer, fuel, phone, cable TV, computer, and site-specific buried cables and lines.

- Visually check for overhead and buried utilities within the drilling site and review the utility maps to determine safe locations for soil borings.

- Scan areas around landfills with surface seismic equipment before drilling to reduce the potential for striking drums or other dangerous buried objects.

- Avoid excessive contact with drill rig when drilling around landfills, potential explosives, or during thunderstorms.

- Do not drill when lightning strikes pose a potential risk.

- Park drill rig across the fall line of the terrain (rather than nose up or down).

- Prevent the rig form rolling by engaging the emergency brake and blocking the wheels using wheel chocks or wooden blocks as necessary.

- Level rig using jacks or chocks.

- See Table 13.1 for safe working distances from power transmission lines. Be aware of overhead lines having long spans with the potential for moving laterally or vertically in the wind. While in transit with mast lowered, maintain a minimum clearance of $10 \mathrm{ft}$.

- Before mast is raised:

- Check cables for signs of stress and entanglement. 
MARTIN MARIETTA

ENERGY SYSTEMS, INC.

Oak Ridge National Laboratory
Pollutant Assessments Group

Health and Safety

Procedures Manual
Sect. 13 Rev. 2

Date $6 / 92$

Page 8 of 12

\section{SUBJECT: SAMPLING AND DRILLING SAFETY PROCEDURES}

- Check to be certain no loose equipment or tools are on the mast.

- Raise the mast after confirming that everyone is standing clear of the drill rig.

- Assign a qualified person to observe the mast clearance and give warning if problems occur.

- Drill mast height determines the minimum exclusion zone radius unless the SSHO or SPM designates a larger exclusion zone.

- As the drill mast is being raised, watch for falling objects and tangling of cables and hoses.

- Make certain that exhaust from the drill rig is safely routed away form the borehole to prevent interference with drilling, sampling, or air monitoring activities.

3. Prepare exclusion zone for operation.

- Station at least one person trained in emergency response actions outside the exclusion zone at all times. Those outside the exclusion zone may pass decontaminated equipment into the zone.

- All personnel working within the exclusion zone at the drill site must wear hard hats, steel-toed boots, safety glasses, and hearing protection.

- Loose clothing and jewelry are not allowed.

- Prior to entering the exclusion zone, dress in the appropriate level of PPE.

- No unnecessary personnel or support vehicles are allowed within the exclusion zone.

- Cover, fence, or enclose all open pits and sumps.

- Set up equipment on plastic sheeting or on tables constructed of chemicalresistant material.

- Establish a personnel decontamination zone according to the site health and safety plan. Include a soap wash and a clean-water rinse.

- Be aware of the location of eye-wash facilities and how they are operated.

- Store solvents and sample preservatives in tightly closed containers in a cool, well-ventilated area away form ignition sources, other reagents, food, beverages, potential contaminating sources, and smoking materials.

- Use and maintain light fixtures in conformance with 29 CFR 1910.181

- Equip fixed lighting with reflectors or shield and place them to minimize glare.

- When used, fasten flood lights or hangers to the mast with safety straps.

- Cover all light bulbs to prevent glass breakage.

- Use only UL-approved electrical cords.

- Use the appropriate gauge for the electrical extension cord length.

- Replace frayed and broken cords. Do not repair.

- Use three-wire grounded-type electrical plug receptacles. 
MARTIN MARIETTA

ENERGY SYSTEMS, INC.

Oak Ridge National Laboratory
Pollutant Assessments Group

Health and Safety

Procedures Manual
Sect. 13 Rev. 2

Date 6/92

Page 9 of 12

\section{SUBJECT: SAMPLING AND DRILLING SAFETY PROCEDURES}

- Space receptacles around the drilling rig to eliminate any need for extremely long extension cords.

- One long cord is preferable to numerous short cords.

- Keep plug ends of cords away form water.

5. Prepare monitoring equipment.

- Calibrate all monitoring equipment off-site in a relatively contaminant-free location, preferably upwind from drilling locations. Monitoring equipment that is sensitive to water may be wrapped in plastic bags that will be replaced from site to site to control possible contamination.

- Before drilling operations begin, monitor the air at the top of the potential borehole and in the breathing zone.

- During the entire drilling process, if potential exposure hazards are suspected, the breathing zone, borehole, and each sample are monitored.

- Record these readings in a logbook or on the Air Quality Monitoring form.

- When any of the following conditions prevail, leave the site immediately, moving to a predetermined upwind location.

- monitoring equipment indicates that air quality limits (action levels) have been reached;

- irritation of mucous membranes, eyes, or skin occurs;

- contaminants known or suspected of presenting a hazard are visually observed; and

- downhole atmospheric conditions approach combustible levels.

6. Be aware of potential hazards during drilling.

- Keep cables, hand tools, shovels, loose hair, loose clothing, feet, and hands away from augers and other moving parts when rig is in operation.

- Use auger fork to stabilize auger in the boring each time a connection is changed.

- Note all changes in lithology of drill cuttings because this may indicate variance in chemical contaminants, geologic structures, and/or aquifer conditions.

- Drilling will be halted by the operating supervisor if a potentially hazardous subsurface obstruction is encountered or drill cuttings are found to be contaminated. Drilling will not resume until the SPM and SSHO determine that further drilling can be conducted safely.

- During instances of unusual loading on the mast, such as pulling or jarring, only the driller should be within the mast height of the drill rig.

- Wear a safety belt secured to the mast whenever working at a height of $6 \mathrm{ft}$ or more above the working surface. Attach the safety belt by means of a lanyard to a fixed anchor and adjust to allow a maximum drop of no more than $6 \mathrm{ft}$. 
MARTIN MARIETTA ENERGY SYSTEMS, INC.

Oak Ridge National Laboratory
Pollutant Assessments Group

Health and Safety

Procedures Manual
Sect. 13 Rev. 2

Date 6/92

Page 10 of 12

\section{SUBJECT: SAMPLING AND DRILLING SAFETY PROCEDURES}

- Do not leave the exclusion zone without decontamination after drilling operations have begun unless instructed to do so by the SSHO.

- If evacuation is necessary, observe the following:

- All personnel meet at a predesignated area to make certain that all have safely evacuated the drilling site.

- The SSHO determines if it is necessary to notify emergency response personnel.

- The SSHO determines when it is safe to return to the site and if it is necessary to upgrade PPE.

- When installing a well, add bentonite slowly, being very careful to suppress dust when at all possible. Use all precautions to keep inhalation of bentonite dust at a minimum.

7. Be aware of potential hazards during sampling.

- Throughout any sampling operation, be aware of and pay attention to the potential hazards posed by the sampling procedure, the material sampled, and the preservation and decontamination agents used.

- Handle all samples with gloves as called for in the site-specific plan.

- During sample collection, place sample containers on a flat, stable surface. Use absorbent materials where spills may occur.

- Deliver the filled sample container and sampling equipment to the decontamination station for thorough cleaning prior to any further handling.

- Be aware of the location of eye-wash facilities and how they are operated.

- Scan all samples with monitoring equipment during extraction from sampling device.

- When drill cuttings are found to be contaminated, drilling will be halted by the SSHO. Drilling will not resume until the SSHO and SPM determine that further drilling can be conducted safely.

- Driller ensures that no hands or feet are in contact with borehole equipment before drilling begins again after each sampling interval.

- Exclude unnecessary personnel when drilling around landfills, potential explosives, or during thunderstorms.

8. Collecting samples from drums

- Evaluate potential hazards using such resources as the following:

- prior sampling data

- air monitoring data

- manifests 
MARTIN MARIETTA

ENERGY SYSTEMS, INC.

Oak Ridge National Laboratory
Pollutant Assessments Group

Health and Sufety

Procedures Manual
Sect. 13 Rev. 2

Date 6/92

Page 11 of 12

\section{SUBJECT: SAMPLING AND DRILLING SAFETY PROCEDURES}

Table 13.1 Safe working distance from power transmission lines

\begin{tabular}{cc}
\hline $\begin{array}{c}\text { Normal voltage, } \\
\text { phase-to-phase } \\
(\mathrm{kV})\end{array}$ & $\begin{array}{c}\text { Minimum required } \\
\text { clearance } \\
(\mathrm{ft})\end{array}$ \\
\hline Up to 50 & 10 \\
$50-200$ & 17 \\
$200-350$ & 22 \\
$350-500$ & 27 \\
$500-750$ & 35 \\
$750-1000$ & 44 \\
\hline
\end{tabular}

- labels (not always accurate!)

- regulatory agency records

- bills of lading

- manufacturing records

- interviews with persons familiar with the site's history.

- Carefully observe the condition of the drum.

- Note any corrosion, bulging, leakage, or stressed or weak points.

- If the drum has been exposed to heat or flame, the contents may be under pressure or may have reacted to form a new, more dangerous compound.

- If the drum is made of plastic or if the bung opening or lining is plastic, the contents are likely to be highly corrosive.

- If it is possible that the drum contains highly flammable, explosive, reactive, or shock-sensitive material, special techniques and equipment will be needed.

- When drums are stacked, piled, or otherwise inaccessible, move the drum to be sampled into a more stable position.

- Use a front-end loader or grappler-equipped backhoe to carefully move drum.

- Open a drum only after proper staging.

- Use remote bung-opening or drum-piercing equipment if possible.

- If opening manually, use a nonsparking bung wrench.

- Slowly open the bung one-quarter turn and allow any pressure to escape.

- Repeat, one-quarter turn at a time, until the bung may be opened freely without release of pressure.

- Monitor the drum contents for organic vapors upon opening. 
MARTIN MARIETTA

ENERGY SYSTEMS, INC.

Oak Ridge National Laboratory
Pollutant Assessments Group

Health and Safety

Procedures Manual
Sect. 13 Rev. 2

Date 6/92

Page 12 of 12

\section{SUBJECT: SAMPLING AND DRILLING SAFETY PROCEDURES}

9. Collecting samples from tanks.

- Sample tanks form the top. Use a platform, man-basket, or cherry picker if the tank is old, corroded, or potentially unstable.

- Use the same precautions for venting and monitoring the tank opening as used with drums.

- Make proper electrical grounding and bonding connections between the tank and any metallic sampling equipment.

- If sampling from a valve at the bottom of the tank,

- place absorbent material and sample container below the valve,

- slowly open the valve,

- fill the container, and

- close the valve.

- Do not attempt this bottom-of-the-tank procedure if the valve appears unstable or if emergency plugs and patches and qualified spill control personnel are not present at the time of sampling.

\subsection{REFERENCES}

Code of Federal Regulations-29, Pt. 1900-1910, 1990.

Code of Federal Regulations-30, Pt. 1-199, 1988.

Code of Federal Regulations-40, Pt. 150-189, 1990.

Environment.

EPA. 1981. Health and safety requirements for employees engaged in field activities. Environmental Protection Agency Order 1440.1. U.S. Environmental Protection Agency, July 12, 1981.

NIOSH. 1985. Occupational safety and health guidance manual for hazardous waste site activities. National Institute for Occupational Safety and Health, Occupational Safety and Health Administration, U.S. Coast Guard, and Environmental Protection Agency, DHHS (NIOSH) Publication 85-115, October 1985. 


\section{PHOTOIONIZATION DETECTOR (PID)}

\subsection{PURPOSE}

To describe the equipment and operating procedures for environmental monitoring of toxic gases and vapors using a PID.

\subsection{APPLICABILTTY}

1. The site safety plan shall provide the information on the scope and details of hazardous site monitoring.

2. The portable PID is useful as a general survey instrument at waste sites. A PID is capable of detecting, measuring, and recording real-time levels of many organic and inorganic vapors in air.

3. The PID will respond to most vaporous compounds in air that have an ionization potential less than or equal to that supplied by the ionizing source in the detector, a UV lamp. For this reason, the selection of the appropriate probe is essential in obtaining useful field results. The magnitude of this response is a function of the detector sensitivity and the concentration and ionization potential of the individual compound. Though it can be calibrated to a particular compound, the instrument cannot distinguish between detectable compounds in a mixture of gases and, therefore, indicates an integrated response, which is a function of the response factors and concentrations of all ionizable species present.

4. The analyzer employs the principle of photoionization for detection. This process is termed photoionization because the absorption of ultraviolet light (a photon) by a molecule leads to ionization as shown in the equation:

$$
\mathrm{RH}+\mathrm{h}=\mathrm{RH}^{+}+\mathrm{e}^{-}
$$

where $\mathrm{RH}=$ relative humidity of trace gas, and $\mathrm{h}=\mathrm{a}$ photon with an energy less than or equal to the ionization potential of $\mathrm{RH}$.

5. The sensor consists of a sealed UV light source that emits photons that are energetic enough to ionize many trace species (particularly organics) but do not 
MARTIN MARIETTA

ENERGY SYSTEMS, INC.

Oak Ridge National Laboratory
Pollutant Assessments Group

Health and Safety

Procedures Manual
Sect. 14 Rev. 2

Date 6/92

Page 2 of 21

SUBJECT: PHOTOIONIZATION DETECTOR (PID)

ionize the major components of air such as $\mathrm{O}_{2}, \mathrm{~N}_{2}, \mathrm{CO}, \mathrm{CO}_{2}$, or $\mathrm{H}_{2} \mathrm{O}$. A chamber adjacent to the UV source contains a pair of electrodes. When a positive potential is applied to one electrode, the field created drives any ions formed by absorption of UV light to the collector electrode, where the current (proportional to concentration) is measured. This signal is amplified and conditioned and then sent to the output display.

\subsection{Specification Data}

\section{DESIGN FEATURES}

Range settings

Lamp ratings

optional

Audible alarm,

low or high limit

(optional)

\section{CHARACTERISTICS \\ Detection range \\ Minimum detection level \\ Maximum sensitivity}

Repeatability

Linear range

Useful range

Response time

Ambient humidity

Ambient operating temperature

Operating time on battery, continuous use, without HNU recorder

with HNU recorder (optional)

Recharge time from full discharge Recharge current Battery charge power
0 to $20,200,2000 \mathrm{ppm}$

$10.2 \mathrm{eV}$ standard, 9.5 or $11.7 \mathrm{eV}$

$85 \mathrm{db}$ at $3 \mathrm{ft}$

0.1 to $2000 \mathrm{ppm}$ (parts per million by volume)

$0.1 \mathrm{ppm}$

0 to $20 \mathrm{ppm}$ FSD at SPAN $=9.8$ (full-

scale deflection)

0 to $2 \mathrm{ppm}$ FSD at SPAN $=0.0$

$\pm 1 \%$ of FSD

0.1 to $400 \mathrm{ppm}$

0.1 to $2000 \mathrm{ppm}$

Less than $5 \mathrm{~s}$ to $90 \%$ of FSD

up to $90 \%$ RH (relative humidity)

-10 t? $40^{\circ} \mathrm{C}$

Approximately $10 \mathrm{~h}$; at lower temperatures time is reduced because of the effect of cold temperature on the battery

Approximately one-half of normal time

Full recharge -13 to $14 \mathrm{~h}$

Max 0.4 amps at $15 \mathrm{~V}$ dc $120 \mathrm{~V}$ ac, single phase, 50 to 60 cycle, $1.5 \mathrm{~A}$ 
MARTIN MARIETTA

ENERGY SYSTEMS, INC.

Oak Ridge National Laboratory
Pollutant Assessments Group

Health and Safety

Procedures Manual
Sect. 14 Rev. 2

Date 6/92

Page 3 of 21

SUBJECT: PHOTOIONIZATION DETECTOR (PID)

WARNING: When equipped with 10.2-eV probe with SPAN set at 9.8 and measuring benzene, values will vary for other compounds and conditions.

\section{Controls and Indicators}

The controls and indicators specific to this instrument are detailed in Table 14.1. Indicators and displays are detailed in Table 14.2.

Table 14.1. Controls

\begin{tabular}{|c|c|c|}
\hline Name & Position & Function \\
\hline Function & -- & Controls the operation of the analyzer \\
\hline \multirow[t]{6}{*}{ Switch } & OFF & All operations OFF \\
\hline & $\begin{array}{l}\text { BATT (battery } \\
\text { check) }\end{array}$ & $\begin{array}{l}\text { Checks the condition of the battery. If the } \\
\text { meter needle is in the green arc, the } \\
\text { battery is charged. If not, the battery } \\
\text { should be recharged. Charging can be } \\
\text { done in any position, best in OFF; see } \\
\text { directions on charger }\end{array}$ \\
\hline & STANDBY & $\begin{array}{l}\text { All electronics ON, ultraviolet (UV) light } \\
\text { source OFF. This position is used to set } \\
\text { the analyzer zero position (i.e., no UV } \\
\text { light, no signal) }\end{array}$ \\
\hline & $0-2000$ & Sets range of meter at $0-2000 \mathrm{ppm}$ \\
\hline & $0-200$ & Sets range of meter at $0-200 \mathrm{ppm}$ \\
\hline & $0-20$ & Sets range of meter at $0-20 \mathrm{ppm}$ \\
\hline ZERO & - & $\begin{array}{l}\text { With the function switch in STANDBY } \\
\text { position, this potentiometer is used to } \\
\text { adjust the reading to zero }\end{array}$ \\
\hline SPAN & -- & $\begin{array}{l}\text { This vernier potentiometer is used to set the } \\
\text { gain of the amplifier to give the direct } \\
\text { readings of the trace gas concentrations in } \\
\text { ppm. The whole number of the setting } \\
\text { appears in the window of the control; } \\
\text { decimal appears on the dial. A lock } \\
\text { secures it at a specific setting }\end{array}$ \\
\hline
\end{tabular}


MARTIN MARIETTA

ENERGY SYSTEMS, INC.

Oak Ridge National Laboratory
Pollutant Assessments Group

Health and Safety

Procedures Manual
Sect. 14 Rev. 2

Date 6/92

Page 4 of 21

SUBJECT: PHOTOIONIZATION DETECTOR (PID)

Table 14.1 (continued)

\begin{tabular}{|c|c|c|}
\hline Name & Position & Function \\
\hline \multirow[t]{3}{*}{ HI-VOLTAGE } & $\cdots$ & This is a normally open microswitch \\
\hline & Open & $\begin{array}{l}\text { Switch is open when the cable is not } \\
\text { connected, disconnecting high voltage for } \\
\text { the UV lamp from the 12-pin connector } \\
\text { as a safety precaution }\end{array}$ \\
\hline & Closed & $\begin{array}{l}\text { Switch is automatically closed when the } \\
\text { cable is attached. This switch may also be } \\
\text { closed manually during maintenance } \\
\text { checks of the readout assembly without } \\
\text { the probe cable attached }\end{array}$ \\
\hline $\begin{array}{l}\text { ALARM SET } \\
\text { (optional) }\end{array}$ & -- & $\begin{array}{l}\text { Potentiometer with screwdriver adjustment. } \\
\text { Turns the audible alarm ON or OFF and } \\
\text { sets the ppm level at which the alarm } \\
\text { sounds. If alarm is low limit, it sounds } \\
\text { when measured ppm falls below this } \\
\text { value. If alarm is high limit, it sounds } \\
\text { when measured ppm exceeds this value }\end{array}$ \\
\hline
\end{tabular}


MARTIN MARIETTA

ENERGY SYSTEMS, INC.

Oak Ridge National Laboratory
Pollutant Assessments Group

Health and Safery

Procedures Manual
Sect. 14 Rev. 2

Date 6/92

Page 5 of 21

SUBJECT: PHOTOIONIZATION DETECTOR (PID)

Table 14.2. Indicators and displays

\begin{tabular}{ll}
\hline \multicolumn{1}{c}{ Name } & \multicolumn{1}{c}{ Function } \\
\hline $\begin{array}{l}\text { Low battery indicator } \\
\text { light (red light) }\end{array}$ & $\begin{array}{c}\text { Illuminates when battery is discharged, indicates need } \\
\text { for recharge } \\
\text { Do not use unit when light is ON } \\
\text { Readings may be taken while battery is being charged } \\
\text { Indicates concentration of measured gas } \\
\text { Meter }\end{array}$ \\
Recorder (optional) & $\begin{array}{l}\text { Provides a record of readings while analyzer operates } \\
\text { unattended } \\
\text { Recorder inputs } 0 \text { to }-5 \mathrm{~V} \mathrm{dc}\end{array}$ \\
\hline
\end{tabular}

\section{WARNINGS}

- The following warnings appear in the operator's manual and are repeated here for emphasis.

- Do not look at the light source from closer than 6 in. with unprotected eyes. Observe only briefly. Continued exposure to UV energy generated by the light source can be harmful to eyesight.

- The instrument measures gases in the vicinity of the operator, and a high reading when measuring toxic or explosive gases should be cause for immediate action to ensure safety.

- Extreme care must be taken in the handling of gas cylinders. Contents are under high pressure. In some cases, the contents may be hazardous. Many gas suppliers will provide data sheets for the mixtures on request.

- Never open the valve on a gas container without a regulator attached.

- Turn the function switch on the control panel to the OFF position before disassembly; otherwise, high voltages of $1200 \mathrm{~V}$ dc will be present.

- Use great care when operating the analyzer with the readout assembly outside its case because of the presence of $1200 \mathrm{~V}$ dc.

- Be very careful to note the toxic levels and the LELs for personal safety. The PI 101 is a nondestructive analyzer and must be used in a hood when calibrating with toxic or hazardous materials. 


\subsection{OPERATING PROCEDURES}

The following procedures are to be used in operating the analyzer:

1. Unclamp the cover from the main readout assembly.

2. Remove the inner lid from the cover by pulling out the two fasteners.

3. Remove the probe, handle, and cable from the cover. Attach the handle to the front part of the probe.

4. Connect the probe cable plug to the 12-pin keyed socket on the readout assembly panel. Carefully match the alignment slot in the plug to the key in the connector. Screw down the probe connector until a distinct snap and lock is felt.

5. Screw the probe extension into the probe end cap. The probe may be used without the extension if desired.

6. Set the SPAN control for the probe being used (10.2-, 9.5-, or 11.7-eV probes are labeled accordingly) as specified by the initial factory calibration or by subsequent calibrations.

7. Turn the function switch to the BATT (battery check) position. The needle on the meter will go to the green zone if the battery is fully charged. If the needle is below the green arc or if the Low Battery Indicator comes on, the battery must be recharged before the analyzer is used.

8. Set SPAN pot to the desired value based on the gas to be used.

9. Turn the function switch to the $S$ position. Turn the zero adjustment until the meter needle is at zero.

10. Calibrate the instrument as described in Sect. 3. Calibration should be performed on the $0-20$ operating range.

11. If equipped with optional alarm, set or check the alarm setting at the level desired. Turn the function switch to the desired range; turn the zero adjustment control so that the meter needle moves upscale through the desired value. This simulates real conditions. Observe the reading when the alarm sounds, adjust the ALARM SET, if required, with a screw iriver. Turn the function switch to the STANDBY position and reset the zero prosition (step 8). If the range is to be changed, the alarm must be reset on that range.

12. To operate with optional recorder, add the recorder bracket. Remove the plug in the analyzer case and insert power cord into the recorder. Then connect the signal leads to the appropriate jacks in the control module. The recorder is now operational.

NOTE: Ranges must be marked on the char: as the recorder prints the meter display as percentage of full scale.

13. Turn the function switch to the appropriate operating position. Start with the 0-2000 position and then switch to the more sensitive ranges. The UV light 
MARTIN MARIETTA

ENERGY SYSTEMS, INC.

Oak Ridge National Laboratory
Pollutant Assessments Group

Health and Safety

Procedures Manual
Sect. 14 Rev. 2

Date 6/92

Page 7 of 21

\section{SUBJECT: PHOTOIONIZATION DETECTOR (PID)}

source should be on; confirm by briefly looking into the probe to observe a purple glow from the lamp.

14. The analyzer is now operational. Make certain the instrument is fully operational before entering a potentially hazardous area.

15. Hold the probe so that the extension is at the point where the measurement is to be made. The instrument measures the concentration by drawing the gas in at the end of the extension, through the ionization chamber, and out the handle end of the probe.

WARNING: The instrument measures gases in the vicinity of the operator and a reading that exceeds current safety engineered procedures when measuring toxic or explosive gases should be cause for personnel to evacuate the area.

16. Take the reading or readings as desired, accounting for currents or drafts in the vicinity of the probe tip, which may cause rapid fluctuations. High humidity will induce rapid gain but slow return to ambient air.

17. Record the field data on the air quality monitoring record (Fig. 14.1).

For actual field use see Sect. 7.1.

\subsection{RECORDING THE PID OFFICE CHECK}

\subsubsection{Recording Data}

Record the necessary calibration data in the office and field log books including

1. Date and time of entry.

2. Site identification.

3. Instrument and probe numbers, model and serial number.

4. Calibration gas used.

5. Name of the instrument operator.

\subsubsection{Postoperation}

1. After completion of use, check battery condition as described in step 7 of Sect. 14.4.

2. Turn function switch to OFF position.

3. When not operating, leave analyzer in assembled condition and connected to battery charger. 
MARTIN MARIETTA

ENERGY SYSTEMS, INC.

Oak Ridge National Laboratory
Pollutant Assessments Group

Health and Safety

Procedures Manual
Sect. 14 Rev. 2

Date 6/92

Page 8 of 21

\section{SUBJECT: PHOTOIONIZATION DETECTOR (PID)}

PAGE

OF

AIR QUALITY MONITORING RECORD

SITE

ON-SITE TIME-START

AMBIENT WEATHER DATA

TEMPP

${ }^{\circ} \mathrm{F}$ BAROMETRIC PRESSURE

SAMPLE STATION

INSTRUMENT

CONDITIONS (I.E., FOG, RAIN)

WIND SPEED/DIRECTION

PID MEASUREIMENTS

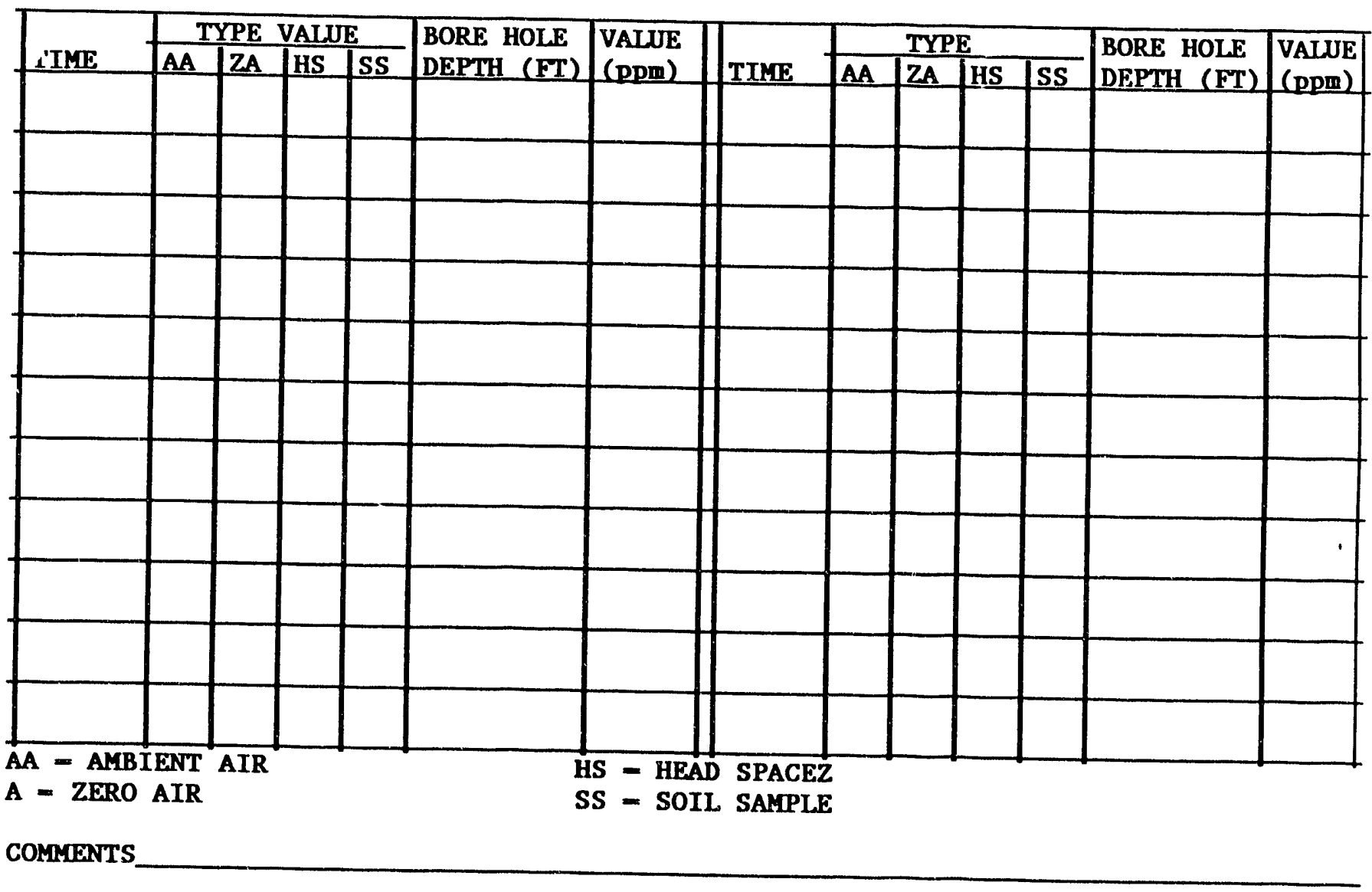

SIGNATURE

Fig. 14.1. Air quality monitoring record. 
MARTIN MARIETTA

ENERGY SYSTEMS, INC.

Oak Ridge National Laboratory
Pollutant Assessments Group

Health and Safety

Procedures Manual
Sect. 14 Rev. 2

Date 6/92

Page 9 of 21

SUBJECT: PHOTOIONIZATION DETECTOR (PID)

4. For equipment repair, complete the ORNL service request form (Fig. 14.2) on returning the equipment to the office electronics technician.

5. When transporting, disassemble probe and extension from readout assembly and return equipment to its stored condition.

\subsection{BATTERY CHARGING}

Check the battery charge during each period of operation or at least once daily. If the battery is low as indicated by the meter reading or the warning indicator, it is necessary to recharge the battery.

To charge the battery, first insert the mini phone plug of the charger into the jack (J6) on the side of the bezel adjacent to the meter. Insert the charger plug into a 120 or $230 \mathrm{~V}$ ac single phase, 50-60 cycle outlet. To ensure that the charger is functioning, turn the function switch (S1) to the battery check (BATT) pusition. The meter should deflect full scale if the charger is working and connections are properly made. For normal battery charging, leave the function switch in the OFF position.

The analyzer can be operated while recharging by turning the function switch to the desired position, but such usage will extend the time required to completely recharge the battery. The battery charger is not intrinsically safe.

On all PI 101s it is necessary to connect the probe assembly before turning on the instrument and recharging. Not following this procedure will prevent the instrument from indicating "battery check"

\subsection{OPTIONAL EQUIPMENT}

The PI 101 is designed for use with interchangeable probes and lamps of different energies. The analyzer is ready for use simply by connecting the probe to the readout assembly, setting the proper SPAN pot value, and then zeroing the unit. Specific data is given in the calibration memo accompanying each probe.

The standard probe uses a 10.2-eV lamp. Two optional probes use 9.5- and 11.7-eV lamps. Lamps of different electron-volt ratings, ion chambers, and amplifiers are not interchangeable. Many applications make use of the principle that some compounds respond to the more energetic lamps and not to others. 
MARTIN MARIETTA

ENERGY SYSTEMS, INC.

Oak Ridge National Laboratory
Pollutant Assessments Group

Health and Safety

Procedures Manual
Sect. 14 Rev. 2

Date 6/92

Page 10 of 21

\section{SUBJECT: PHOTOIONIZATION DETECTOR (PID)}

GJ NO.

I\&C NO

Date Initiated:

To:

From:

Notes:

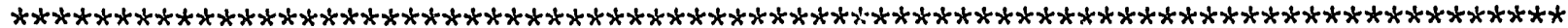

1) Instrument or Device:

2) Service Requested:

Repair

Modification

Inspection

Calibration

3) Description of Symptoms:

Faulty cable

Separated cable

Audio circuit

Meter malfunction (please describe below)

Loose connector(s)

Loose handle

Mismatched box and probe

other

4) Miscellaneous:

Fig. 14.2 ORNL service request. 
MARTIN MARIETTA

ENERGY SYSTEMS, INC.

Oak Ridge National Laboratory
Pollutant Assessments Group

Health and Safety

Procedures Manual
Sect. 14 Rev. 2

Date $6 / 92$

Page 11 of 21

SUBJECT: PHOTOIONIZATION DETECTOR (PID)

An optional audible alarm is available that gives an $85-\mathrm{dB}$ signal when a set concentration is exceeded. The alarm setting is variable and can be set from 0 to $100 \%$ of full scale of the meter reading. Power for the alarm is provided by the battery and does not significantly affect the rated use time of the analyzer. The alarm is nonlatching and is set by a screw adjustment, preventing inadvertent changes.

When in the stored condition, the probe is contained in the instrument cover, which attaches to the readout assembly to form a single unit.

An optional recorder is available that can be directly attached to the readout assembly. It uses impact paper with a 2 -in.-wide chart and a speed of $2 \mathrm{in} . / \mathrm{h}$. The recorder is powered by the instrument battery and provides a hard copy of the data. The analyzer will operate for approximately $4 \mathrm{~h}$ with the recorder attached.

\subsection{PID CALIBRATION}

\subsubsection{Introduction}

The PI 101 Analyzer is designed for trace gas analysis in ambient air and is calibrated at HNU with certified standards of benzene, vinyl chloride, and isobutylene. Other optional calibrations are available (e.g., ammonia, ethylene oxide, $\mathrm{H}_{2} \mathrm{~S}$ ). Calibration data is given on the data sheet. If a special calibration has been done, the data is given on the air quality monitoring form, which notes the sample source and type of calibration (Fig. 14.1).

Good instrumentation practice calls for calibration on the species to be measured in the concentration range to be used. This procedure assures the operator that the analyzer is operating properly and will generate reliable data.

Some general points to consider when calibrating the PI 101 are that the analyzer is designed for operation at ambient conditions, and therefore, the gas standards used for calibration should be delivered to the analyzer at ambient temperatures and pressure and at the proper flow rates.

WARNING: The PI 101 is a nondestructive analyzer; calibrations using toxic or hazardous gases must be performed in a hood or with adequate outdoor ventilation.

The frequency of calibration should be dictated by the usage of the analyzer and the toxicity of the species measured. If the analyzer has been serviced or repaired, calibration should be done to verify operation and performance. It is recommended that calibration 
SUBJECT: PHOTOIONIZATION DETECTOR (PID)

be checked frequently at first (daily or every other day) and then regularly, based on the confidence level developed.

The normal meter scale plate is 05020 . If the scale plate is different, refer to the application data sheet. If there are questions, consult the electronics technician before proceeding with calibration check.

An accurate and reliable method of calibration check is to use an analyzed gas cylinder in a test setup as described in Sect. 14.8.2. Additional material on calibration is given in Sect. 14.8.5. An equipment checklist for field calibration of the PID is detailed in Fig. 14.3.

\subsection{Calibration Gas Cylinder}

1. Concentration-The calibration gas cylinder is to contain the species of interest made up in an air matrix at or near the concentration to be analyzed. If the component is unstable in air, another matrix is to be used. The final calibration mixture should be similar to the sample the PI 101 will analyze. If the expected concentration is not known, then a concentration should be chosen that will cause a scale displacement of 50 to $80 \%$ on the $\mathrm{X} 10$ range. Calibration on the $\mathrm{X} 10$ range will provide accurate values on the $\mathrm{X} 1$ range as well.

For use on the 0-2000 range, a two-standard calibration is preferred: one at 70 to $85 \%$ of the linear range and the other at 25 to $35 \%$ of the linear range. With the linear range of approximately $600 \mathrm{ppm}$ for most compounds, these points would lie between 420 to $510 \mathrm{ppm}$ and 150 to $210 \mathrm{ppm}$, respectively.

2. Stability-The calibration gas must be stable within the cylinder during the period of use. If calibration is required in the field, the use of a small cylinder is recommended. In addition, the choice of cylinder material in contact with the gas must be considered (steel, aluminum, or Teflon). If there are any questions, the operator should request stability and usage information from the gas supplier.

WARNING: Extreme care must be taken in the handling of gas cylinders. Contents are under high pressure and, in some cases, may be hazardous. Many gas suppliers will provide data sheets for the mixtures on request.

3. Delivery-The cylinder containing the calibration mixture must be connected to a proper regulato'.

WARNING: Never open the valve on a gas cylinder container unless a regulator is attached. 
MAR'TIN MARIETTA

ENERGY SYSTEMS, INC.

Oak Ridge National Laboratory
Pollutant Assessments Group

Health and Safery

Procedures Manual
Sect. 14 Rev. 2

Date 6/92

Page 13 of 21

\section{SUBJECT: PHOTOIONIZATION DETECTOR (PID)}

1.

PID Manufacturer

HNU Systems, Inc

Mode 1_PI-101

Serial Number

Location Number

2. Operating Manual

3. Probe: $9.5 \mathrm{eV}$ , $10.2 \mathrm{eV}$ $11.7 \mathrm{eV}$

4.

Battery charger for PID

5.

Jeweler's Screwdriver for Adjustments

6.

Tygon tubing 3 inches $1 / 4$ inch diameter

7.

Calibration Regulator Valve

8.

Calibration Gas (type)

cylinder ID number concentration (ppm)

9.

"T" Valve for Calibration

10.

Methanol

11.

Acetone

12.

HNU Cleaning Compound 12

13. Freon Solvent

14.

Kim Wipes

15.

Spare Parts

16.

Field Data Forms

17.

Instrument Log Book

Fig. 14.3. Photoionization dectector checklist. 
MARTIN MARIETTA

ENERGY SYSTEMS, INC.

Oak Ridge National Laboratory
Pollutant Assessments Group

Health and Safety

Procedures Manual
Sect. 14 Rev. 2

Date 6/92

Page 14 of 21

SUBJECT: PHOTOIONIZATION DETECTOR (PID)

4. Leak-test all tank/regulator connections as well as the main cylinder valve to prevent toxic or hazardous materials from leaking into the work area. Care must be taken that the materials of construction for the regulator will not interact with the calibration gas.

One method of sampling the calibration gas is to connect the cylinder to one leg of the tee, a flow meter to the opposite leg, and the probe to the third leg. The flow meter does not require a valve. If there is a valve, it must be left wide open. The flow meter is only to indicate excess flow. Adjust the flow from the regulator such that only a little excess flow is registered at the flow meter.

This ensures that the PI 101 sees the calibration gas at atmospheric pressure and ambient temperature.

5. Usage-Generally, a gas cylinder should not be used below 200 to 300 psi because pressure effects could cause concentration variations. The cylinder should not be used past the recommended age of the contents as indicated by the manufacturer. In case of difficulty, verify the contents and concentration of the gas cylinder. A PID checklist is provided in Fig. 14.2.

\subsection{Probe Selection}

1. IJentify the probe by the lamp label. If a question exists, disassemble the probe and inspect the lamp. The energy of the lamp is etched into the glass envelope. Typical applications of interchangeable probes are detailed on Table 14.3.

2. Connect the probe to the readout assembly, making sure the red interlock switch is depressed by the ring on the connector.

3. Set the SPAN pot to the proper value for the probe being calibrated. Refer to the calibration memo accompanying the probe.

d. Check the ionization potential (IP) of the calibration gas to be used. The IP of the calibration gas must be at or below the IP of the lamp.

e. Proceed with the calibration as described in Sect. 14.8. Check the calibration memo for specific data. If any questions develop, call the HNU representative.

f. The 11.7-eV lamp has a special cleaning compound. Do not use water or any other cleaning compound on the 11.7-eV lamp. Do not interchange ion chambers, amplifier boards, or lamps between probes.

\subsubsection{Calibration Procedures}

1. Battery check-Turn the function switch to BATT. The needle should be in the green region. If not, recharge the battery.

2. Zero set-Turn the function switch to STANDBY. In this position the lamp is OFF and no signal is generated. Set the zero point with the ZERO set control. 
MARTIN MARIETTA ENERGY SYSTEMS, INC.

Oak Ridge National Laboratory
Pollutant Assessments Group

Health and Safety

Procedures Manual
Sect. 14 Rev. 2 Date 6/92

Page 15 of 21

SUBJECT: PHOTOIONIZATION DETECTOR (PID)

Table 14.3. Typical applications of interchangeable probes

\begin{tabular}{lccc}
\hline & Ionization & \multicolumn{2}{c}{ Relative sensitivity } \\
\cline { 3 - 4 } \multicolumn{1}{c}{ Compound } & $(\mathrm{eV})$ & $9.5 / 10.2 \mathrm{eV}$ & $11.7 / 10.2 \mathrm{eV}$ \\
\hline p-Xylene & 8.44 & 0.10 & 0.104 \\
p-Chlorotoluene & 8.70 & 0.09 & 0.112 \\
Toluene & 8.82 & 0.09 & 0.112 \\
o-Chlorotoluene & 8.83 & 0.075 & 0.112 \\
Ethyl acetate & 9.19 & 0.075 & 0.112 \\
Benzene & 9.24 & 0.10 & 0.10 \\
Methyl mercaptan & 9.24 & 1.0 & 0.072 \\
Pyridine & 9.32 & 0.075 & 0.122 \\
Allyl alcohol & 9.67 & 0.10 & 0.112 \\
Crotonaldehyde & 9.88 & 0.075 & 0.104 \\
Amyl alcohol & 9.80 & 0.09 & 0.116 \\
Cyclohexane & 9.88 & 0.075 & 0.104 \\
Vinyl chloride & 9.95 & 0.085 & 0.112 \\
Butanol & 10.94 & 0.09 & 0.176 \\
Ammonia & 10.15 & 0.006 & 0.160 \\
Acetic acid & 10.37 & 0.04 & 0.560 \\
Ethylene & 10.52 & 0.0 & 0.320 \\
Ethylene oxide & 10.56 & 0.0 & 0.298 \\
\hline
\end{tabular}

${ }^{a}$ Relative sensitivity $=\frac{\text { Response with } 9.5-\text { or } 11.7-\mathrm{eV} \text { probe }}{\text { Response with } 10.2-\mathrm{eV} \text { probe }}$

The zero can also be set with the function switch on the $\mathrm{X} 1$ position and by using a "hydrocarbon-free" air. In this case, "negative" readings are possible if the analyzer measures a cleaner sample when in service.

3. $0-20$ or $0-200$ range-For calibrating on the $0-20$ or $0-200$ range, only one gas standard is required. Turn the function switch to the range position and note the meter reading. Adjust the SPAN control setting as required to read the parts per million concentration of the standard. Recheck the zero setting (step 2). If readjustment is needed, repeat step 3 . This gives a two-point calibration: zero and the gas standard point. 
MARTIN MARIETTA

ENERGY SYSTEMS, INC.

Oak Ridge National Laboratory
Pollutant Assessments Group

Health and Safety

Procedures Manual
Sect. 14 Rev. 2

Date 6/92

Page 16 of 21

SUBJECT: PHOTOIONIZATION DETECTOR (PID)

Additional calibration points can be generated by dilution of the standard with zero air if desired.

4. 0-2000 range-For calibrating on the 0-2000 range, use of two standards is recommended as cited in Sect. 14.8.2. First calibrate with the higher standard by using the SPAN control for setting. Then calibrate with the lower standard by using the ZERO adjustment. Repeat these steps several times to ensure that a good calibration is obtained. The analyzer will be approximately linear to $600 \mathrm{ppm}$ or higher. If the analyzer is subsequently to be used on the 0-20 or 0-200 ranges, it must be recalibrated as described in steps 2 and 3 above.

5. Lamp cleaning - If the span setting resulting from calibration is 0.0 or if calibration cannot be achieved, then the lamp must be cleaned (Sect. 14.12.2).

6. Lamp replacement-If the lamp output is too low or if the lamp has failed, it must be replaced.

\subsubsection{Field Calibration}

Rapid calibration checking in the field can be accomplished by use of a small disposable cylinder containing isobutylene. Immediately after a calibration has been completed, a reading is taken on a special isobutylene standard. This provides a reference concentration measurement for later checking in the field. Checking can be done at any time with a portable cylinder containing this same special standard by using this reference reading as a check and making adjustments to the analyzer if necessary. In effect, this is an indirect method of calibration in which the calibration is maintained to give direct readings for the original gas but is done by using the portable isobutylene cylinder.

\subsection{OPERATION}

\subsubsection{Recording Field Data}

The photoionization detector air quality monitoring record form will be used to record data obtained in the field (Fig. 14.1).

1. Site code: Site-specific alphanumeric codes assigned to sample locations. The numbers are assigned sequentially to any site within an installation subject to an investigation. The character codes indicate the site that is under investigation.

2. Log date: When the form is filled out in the format: day, month, and year.

3. Operator: Person(s) who is operating the PID and recording the data.

4. PID instrument: Manufacturer's name on PID instrument used.

5. Model: Model of PID instrument.

6. Serial No.: Serial No. of PID instrument. 
MARTIN MARIETTA

ENERGY SYSTEMS, INC.

Oak Ridge National Laboratory
Pollutant Assessments Group

Health and Safety

Procedures Manual
Sect. 14 Rev. 2

Date $6 / 92$

Page 17 of 21

\section{SUBJECT: PHOTOIONIZATION DETECTOR (PID)}

7. Date calibrated: Last day on which the PID instrument was calibrated.

8. Calibration gases:

a. Cylinder ID No. Identification number of gas cylinder used to obtain calibration gas.

b. Concentration (ppm). Concentration of calibration gas in parts per million.

9. Location ID: Number assigned uniquely and sequentially to each bore-hole, test pit, surface monitoring location, etc., where physical, chemical, biological, radiological, and any other measurements are taken.

10. Time: Time, using 12-h clock (a.m./p.m. format), at which a field measurement will be taken.

11. Location type: Two-character code identifying where sample was taken. Location types include:

$$
\begin{aligned}
& \text { BH-borehole } \\
& \text { TP-test pit } \\
& \text { SL_-surface location } \\
& \text { WL-well location } \\
& \text { SB-sample bottle } \\
& \text { SS-soil sample } \\
& \text { OT-other (explain) }
\end{aligned}
$$

12. Observed reading: PID reading at the respective location ID in meter units (ppm) when the calibration gas and the gas being measured in the environment are the same.

13. Comments: Any additional information.

\subsection{Hazardous Waste Site Investigation}

1. As with any field instrument, accurate results depend on the operator being completely familiar with the operation of the unit in use. The instructions in the operating manual should be followed explicitly to obtain accurate results.

2. Any personnel performing air monitoring at hazardous waste sites shall do so in conformance with the site safety plan and site work control requirements as listed in Sect. 6.

3. Position intake assembly shall be located in close proximity to the area in question because the low sampling rate allows for only very localized readings.

4. A slow, sweeping motion of intake assembly will help prevent bypassing problem areas.

5. Be prepared to evacuate the area if preset alarm sounds. Operators utilizing supplied air systems may not need to consider this action. 
MARTIN MARIETTA

ENERGY SYSTEMS, INC.

Pollutant Assessments Group

Health and Safety

Sect. 14 Rev. 2

Oak Ridge National Laboratory

Procedures Manual

SUBJECT: PHOTOIONIZATION DETECTOR (PID)

6. Record data on photoionization detector data record form (Fig. 14.2) and in the field logbook.

\subsection{POSTOPERATION}

\subsubsection{Field}

1. Decontaminate or clean instrument as needed. If decontamination is required, follow the procedures specified in Sect. 14.12. If cleaning is required, refer to the manufacturer's operating manual.

2. Complete PID data records forms and the field logbook, checking to verify accuracies of entries and that all pages have been signed or initialed.

\subsubsection{Office}

1. Turn over all PID data records forms and copies of the field logbook pages to the SPM.

2. Charge instrument batteries.

3. Have repairs performed, if needed.

4. Obtain spare parts, if needed.

5. Obtain spare calibration gas, if needed.

\subsection{PID INSTRUMENT LIMITATIONS}

1. The PID is a nonspecific total vapor detector. It cannot be used to identify unknown substances; it can only quantify thein.

2. The PID must be calibrated to a specific compound.

3. The PID does not respond to certain low-molecular-weight hydrocarbons (e.g., methane and ethane); relative photoionization sensitivities for gases are detailed on Table 14.4. A CGI shall be used concurrently to monitor for gases that are not detected by the PID.

4. Certain toxic gases and vapors (e.g., carbon tetrachloride and hydrogen cyanide) have high ionization potentials and cannot be detected with a PID.

5. Refer to manufacturer's operating manual for use in potentially flammable or combustible atmospheres.

6. Electrical power lines or power transformers in close proximity to the PID instrument (10 to $100 \mathrm{ft}$ ) will cause measurement errors.

7. High wind and high humidity will affect measurement readings. 
MARTIN MARIETTA

ENERGY SYSTEMS, INC.

Oak Ridge National Laboratory
Pollutant Assessments Group

Health and Safety

Procedures Manual
Sect. 14 Rev. 2

Date 6/92

Page 19 of 21

\section{SUBJECT: PHOTOIONIZATION DETECTOR (PID)}

8. The lamp window must be cleaned periodically to ensure ionization of the air contaminants.

9. The PID measures concentrations from about 1 to $2000 \mathrm{ppm}$, but the response is not linear over this entire range. The response to benzene, for example, is linear from about 0 to $600 \mathrm{ppm}$. This means the PID reads a true concentration of benzene only between 0 and 600 . Greater concentrations are "read" at a lower level than the true value. The manufacturer's operating manual should be consulted to determine the instrument's response to various chemicals.

Table 14.4 Relative photoionization sensitivities for gases

\begin{tabular}{lcl}
\hline \multicolumn{1}{c}{$\begin{array}{c}\text { Chemical } \\
\text { grouping }\end{array}$} & $\begin{array}{c}\text { Relative } \\
\text { sensitivity }\end{array}$ & \multicolumn{1}{c}{ Examples } \\
\hline Aromatic & 10 & Benzene, toluene, styrene \\
Aliphatic amine & 10 & Diethylamine \\
Chlorinated & 5.9 & Vinyl chloride, vinylidene \\
Unsaturated & 6.2 & Chloride, trichloroethylene (TCE) \\
Carbonyl & 7.9 & MEK, MiBK, acetone, cyclohexane \\
Unsaturated & 3.5 & Arolein, propylene, cyclohexanon, \\
& & allyl alcohol \\
Sulfide & 3.5 & Hydrogen sulfide, methyl mercaptan \\
Paraffin (C5-C7) & 1.3 & Pentane, hexane, heptane \\
Ammonia & 0.3 & \\
Paraffin (C1-C4) & 0 & Methane, ethane \\
\hline
\end{tabular}

${ }^{\circ}$ Relative sensitivity $=$ meter readings when measuring $10 \mathrm{ppm}$ of the listed gas with instrument with $10.2-\mathrm{eV}$ probe calibrated for $10 \mathrm{ppm}$ of benzene, span pot setting $=9.8$ for direct reading of benzene.

\subsection{MAINTENANCE}

\subsection{Introduction}

Maintenance of the analyzer consists of cleaning the lamp and ion chamber and replacing of the lamp or other component parts or subassemblies. 
CAUTION: Do not interchange lamps of different electron-volt ratings in a probe. Amplifier and components are selected for lamp that has a specific electron-volt rating. A probe equipped with the wrong lamp will not operate properly.

\subsection{UV Lamp and Ion Chamber Cleaning}

During periods of analyzer operation, dust or other foreign matter can be drawn into the probe, forming deposits on the surface of the UV lamp or in the ion chamber. This condition is indicated by meter readings that are low, erratic, unstable, nonrepeatable, or drifting or show apparent moisture sensitivity. These deposits interfere with the ionization process and cause erroneous readings. Check for this condition monthly or as required. Cleaning can be accomplished as follows:

1. Disassemble the probe and remove the lamp and ion chamber (see Procedures Manual). Exercise great care in doing so to prevent damage to these components.

2. First check the lamp window for fouling by looking at the surface at an incident angle. Any deposits, films, or discoloration may interfere with the ionization process. Clean the window as indicated below.

\subsection{5- and 10.2-eV Lamps}

1. First clean by rubbing the lamp gently with lens tissue dipped in a detergent solution.

2. If this does not remove deposit, apply a small amount of HNU cleaning compound (PA101534) directly onto the lens of the lamp and spread it evenly over surface with a nonabrasive tissue (e.g., Kim-Wipe) or a lens tissue.

3. Wipe compound off with a new tissue.

4. Rinse the lamp with warm water (about $80^{\circ} \mathrm{F}$ ) or damp tissue to remove all traces of grit or oils and any static charge that may have built up on the lens. Dry it with new tissue.

5. Reinstall lamp in detector and check analyzer operation.

6. If performance is still not satisfactory, replace the lamp.

\subsection{7-eV Lamp}

1. Clean by putting a freoll or chlorinated organic solvent on a tissue and rubbing the lamp gently. 
2. DO NOT CLEAN THIS LAMP WITH WATER OR ANY WATER MISCIBLE SOLVENTS (methanol or acetone). They will damage the lamp.

3. DO NOT USE THE CLEANING COMPOUND used for the 9.5- and 10.2-eV lamps on the 11.7-eV lamp under any circumstances.

4. Inspect the ion chamber for dust or particulate deposits. If such matter is present, the chamber can be cleaned by removing the outer Teflon ring and the four screws holding the retaining ring. Carefully move the retaining ring aside (NOTE: this is soldered) and remove the screen. A tissue or cotton swab, dry or wetted with methanol, can be used to clean off any stubborn deposits. The assembly can also be gently swirled in methanol and dried gently at 50 to $60^{\circ} \mathrm{C}$ for approximately a $1 / 2 \mathrm{~h}$. No liquid must be present at reassembly because this would affect performance. Do not clean the ion chamber with the HNU cleaning compound cited above in item 2 under Sect. 14.12.3.

5. Reassemble the probe and check analyzer operation.

\subsection{REFERENCES}

Code of Federal Regulations-29, Pt. 1900-1910, 7/87.

Code of Federal Regulations-30, Pt. 1-199, 1986.

Code of Federal Regulations-40, Pt. 150-189, 7/86.

EPA. 1981. Health and safety requirements for employees engaged in field activities. Environmental Protection Agency Order 1440.1. U.S. Environmental Protection Agency, July 12, 1981.

HNU Systems, Inc. 1975. Instruction Manual for Model PI 101 Photoionization Analyzer.

NIOSH. 1985. Occupational safety and health guidance manual for hazardous waste site activities. National Institute for Occupational Safety andHealth, Occupational Safety and Health Administration, U.S. Coast Guard, and Environmental Protection Agency, DHHS (NIOSH) Publication 85-115, October 1985. 


\section{SUBJECT: EXOTOX MODEL 50 COMBUSTIBLE GAS INDICATOR (CGI)}

\section{EXOTOX MODEL 50 COMBUSTIBLE GAS INDICATOR (CGI)}

\subsection{PURPOSE}

To describe the equipment and procedures for monitoring combustible gas levels in order to ensure a safe working environment.

\subsection{APPLICABILTY}

The Exotox Model $50 \mathrm{CGI}$, or explosimeter, is used o determine the potential for combustion or explosion of unknown atmospheres. The CGI determines the level of organic vapors and gases present in an atmosphere as a percentage of the lower explosive limit (\% LEL), or lower flammability limit (LFL). It also determines the presence of CO, $\mathrm{H}_{2} \mathrm{~S}$, and the volume percentage of oxygen in air by measuring the change in electrical resistance.

\subsubsection{Specifications}

EXOTOX Model 50 OFHC

Operating temperature: $-15^{\circ} \mathrm{C}\left(5^{\circ} \mathrm{F}\right)$ to $50^{\circ} \mathrm{C}\left(122^{\circ} \mathrm{F}\right)$

Storage temperature: $-20^{\circ} \mathrm{C}\left(-40^{\circ} \mathrm{F}\right)$ to $55^{\circ} \mathrm{C}\left(131^{\circ} \mathrm{F}\right)$

Humidity: 0 to $99 \%$ RH (noncondensing)

Battery capacity: Minimum 12 h, typically 16 h

\subsubsection{Normal Operation}

1. Switch the instrument on by firmly pressing the POWER button. The display will flash a software identification code. (This is a service tool and should be ignored by the user.) The instrument will now enter its SELF-TEST sequence. During SELF-TEST, the EXOTOX 50 LEDs and all display segments will flash eight times. Approximately $3 \mathrm{~s}$ after being switched on, the audio alarm tone will "bleep" ten times and the four yellow LEDs will flash in synchronization with the tones. 


\section{SUBJECT: EXOTOX MODEL 50 COMBUSTIBLE GAS INDICATOR (CGI)}

2. After the SELF-TEST sequence is completed, the instrument will automatically enter its oxygen display mode. The operator may now select the display mode by using the SELECT button. Momentary depression of this button causes the mode to change to the next sequence. Repetitive depression of the SELECT button will cause the EXOTOX to step through the display modes.

3. The EXOTOX will continue to display the selected mode until it is either switched to another mode or an alarm condition is detected. When an alarm condition is detected, the EXOTOX will automatically select (default to) the display mode of the relevant alarm.

4. While the instrument is in one of the normal operating modes (Sect. 15.2.3) the speaker will emit a WATCHDOG bleep once every $10 \mathrm{~s}$. The WATCHDOG informs the operator that the instrument is operating normally in a safe environment.

5. The instrument will generate the WATCHDOG bleep until an alarm condition is detected and it defaults to an alarm mode.

WARNING: DO NOT hold the SELECT button down because this will cause the instr ument to enter its "Standby Mode" (Sect. 15.2.6).

\subsection{Mode Selection (Normal Operating Modes)}

After the SELF-TEST sequence is complete, the operating modes are selected by momentary depression of the SELECT button.

Each time the SELECT button is depressed, the instrument will switch to the next mode in the following sequence.

\section{Display mode sequence}

1 Oxygen real-time display

2 Carbon monoxide real-time display

3 Carbon monoxide TWA display

4 Carbon monoxide STEL display

5 Hydrogen sulfide real-time display

6 Hydrogen sulfide TWA display

7 Hydrogen sulfide STEL display

8 Explosive gas display

9 Clock display

10 Oxygen real-time display, etc. 
MARTIN MARIETTA

ENERGY SYSTEMS, INC.

Oak Ridge National Laboratory
Pollutant Assessments Group

Health and Safety

Procedures Manual
Sect. 15 Rev. 2

Date 6/92

Page 3 of 25

SUBJECT: EXOTOX MODEL 50 COMBUSTIBLE GAS INDICATOR (CGI)

NOTE: Some models have slightly different sequences. The order of the sequence may vary, and some display modes may not be featured in the sequence.

\subsubsection{Channel LEDs}

The gas measurement being displayed on the instrument's LCD display is indicated by one of the four yellow LEDs. These are marked $\mathrm{CO}, \mathrm{H}_{2} \mathrm{~S}, \mathrm{O}_{2}$, and EXP.

\subsubsection{Oxygen real-time display mode}

In this mode the display indicates the current concentration of oxygen in the atmosphere in volume percent terms. The instrument has a display range of 0 to $32.0 \%$.

\subsubsection{Carbon monoxide real-time display mode}

Here, the display indicates the current concentration of $\mathrm{CO}$ in the atmosphere. The readout is in parts per million, and the instrument has a range of 0 to $999 \mathrm{ppm}$.

\subsection{Carbon monoxide TWA display mode}

This display mode indicates the TWA exposure to $\mathrm{CO}$ since the instrument was switched on. The figure is derived from the aggregate exposure averaged over $8 \mathrm{~h}$.

\subsubsection{Carbon monoxide STEL display}

In this mode, the display indicates the STEL to CO. This is the aggregate exposure in the previous $10 \mathrm{~min}$.

\subsubsection{Hydrogen sulfide real-time display}

This mode's display indicates the current concentration of $\mathrm{H}_{2} \mathrm{~S}$ in the atmosphere. The readout is in parts per million, and the instrument has a range of 0 to $500 \mathrm{ppm}$. 
MARTIN MARIETTA

ENERGY SYSTEMS, INC.

Oak Ridge National Laboratory
Pollutant Assessments Group

Health and Safety

Procedures Manual
Sect. 15 Rev. 2

Date 6/92

Page 4 of 25

SUBJECT: EXOTOX MODEL 50 COMBUSTIBLE GAS INDICATOR (CGI)

\subsubsection{Hydrogen sulfide TWA display mode}

This mode's display represents the TWA exposure to gas since the instrument was switched on. The figure is derived from the aggregate exposure averaged over $8 \mathrm{~h}$.

\subsubsection{Hydrogen sulfide STEL display}

The display indicates the short-term exposurf, limit to $\mathrm{H}_{2} \mathrm{~S}$. This is the aggregate exposure in the previous $10 \mathrm{~min}$.

\subsubsection{Explosive gas display mode}

In this mode the display indicates the real-time concentration of explosive gases as a percentage of the LEL.

\subsubsection{Clock display mode}

The elapsed time since instrument was switched on is displayed in hours and decimal hours (up to a maximum of 99.9). The display alternates between the elapsed time readout and an alphanumeric display of " $\mathrm{Hr}$." $(0.1 \mathrm{~h}=6 \mathrm{~min})$.

\subsection{LCD backlight}

The EXOTOX display has a backlight facility. To operate, depress and hold the backlight button. The backlight only operates while the button is depressed.

\subsection{Warnings, Faults, and Alarms}

The EXOTOX 50 informs the operator of a number of different hazardous situations. In addition to the nine gas alarm modes, the EXOTOX will also warn the operator of potentially hazardous situations and inform him/her of instrument malfunctions.

The four real-time alarm modes occur when the monitored concentration of one of the four gases exceeds preset limits. The EXOTOX also warns the operator when the STEL for one of the toxic gases exceeds a preset limit. Long-term exposure (LTE) to toxic gases is constantly monitored, and the TWA alarm modes inform the operator when exposure exceeds preset safety levels. 
MARTIN MARIETTA

ENERGY SYSTEMS, INC.

Oak Ridge National Laboratory
Pollutant Assessments Group

Health and Safety

Procedures Manual
Sect. 15 Rev. 2

Date 6/92

Page 5 of 25

SUBJECT: EXOTOX MODEL 50 COMBUSTIBLE GAS INDICATOR (CGI)

If an alarm condition is detected, a pulsing bleep will sound and the display will switch to the parameter that is in an alarm condition.

NOTE: The audio tone is different for explosive gas alarms (Sect. 15.2.4.4).

Simultaneously, the relevant annunciator lights up and the channel LED

flashes. See Sect. 15.2.4.3 for multiple alarm indications.

\subsubsection{Alarm cancel}

Depending on the relative importance of the detected alarm, it may be possible for the operator to cancel the alarm warning. To do this the operator must depress and hold the SELECT button for at least $3 \mathrm{~s}$. The instrument will now return to its normal mode of operation, except for the WATCHDOG bleep, which will now be a double bleep once every $10 \mathrm{~s}$.

The EXOTOX will recheck a cancelled alarm after $30 \mathrm{~s}$. If the alarm condition is still present, the EXOTOX will once more enter the relevant alarm mode and sound the alarm tone. If the alarm condition is no longer present, then the EXOTOX will "time-out" and return to its normal operating mode, except for the WATCHDOG bleep, which will continue as a double bleep to remind the operator that there has previously been an alarm.

\subsubsection{Subsequent alarms}

Subsequent alarms may also be cancelled.

\section{Multiple alarms}

When a number alarms occur simultaneously, the EXOTOX will switch to a display of the most important alarm. This is referred to as the priority alarm. The channel LED, related to the priority alarm, will flash out of synchronization with the alarm tone. The LED related to the nonpriority alarm will flash in synchronization with the alarm tone. This gives the operator a visual indication of multiple gas alarms.

The priority of the alarms and faults are shown in Table 15.1. This table also indicates which alarms can be cancelled. 
MARTIN MARIETTA

ENERGY SYSTEMS, INC.

Oak Ridge National Laboratory
Pollutant Assessments Group

ilealth and Safery

Procedures Manual
Sect. 15 Rev. 2

Date 6/92

Page 6 of 25

SUBJECT: EXOTOX MODEL 50 COMBUSTIBLE GAS INDICATOR (CGI)

Table 15.1. Alarm mode priority

\begin{tabular}{lcc}
\hline \multicolumn{1}{c}{ Alarm/fault } & Priority & Cancelable \\
\hline Battery exhaustion alarm & Overriding & No \\
Reference fault & Top & No \\
Oxygen fault & Top & No \\
Explosive fault & Top & No \\
Oxygen HI \& LO real-time & 2 & Yes \\
Hydrogen sulfide real-time & 3 & Yes \\
Carbon monoxide real-time & 4 & Yes \\
Explosive real-time & 5 & Yes \\
Hydrogen sulfide STEL & 6 & Yes \\
Carbon monoxide STEL & 7 & Yes \\
Hydrogen sulfide TWA & 8 & Yes $^{a}$ \\
Carbon monoxide TWA & 9 & Yes $^{a}$ \\
\hline
\end{tabular}

TWA alarms may be cancelled. The stored date is not reset so the TWA alarm will automatically reappear after the time-out period of $30 \mathrm{~s}$. WARNING: IN THE EVENT OF A BATTERY EXHAUSTION ALARM, LEAVE THE HAZARDOUS AREA IMMEDIATELY, SWITCH THE EXOTOX OFF, AND RECHARGE OR REPLACE THE BATTERY IN A SAFE AREA.

\subsubsection{Alarm modes}

There are many alarm modes that warn the operator of potentially dangerous environments. There are a number of different tones that alert the operator to the various alarm conditions. Some mention must be made of the explosive alarm tone, which is different from the standard alarm tone for the other gases.

Note 1 Standard alarm tone. The standard alarm tone is a continuous bleeping alarm.

Note 2 The explosive alarm tone is a pulsing double-bleep alarm.

Note 3 Whenever a multiple alarm condition appears that includes an explosive alarm or fault, the explosive alarm tone takes precedence over the standard alarm tone.

The various alarm indications are detailed in Table 15.1 . 
MARTIN MARIETTA

ENERGY SYSTEMS, INC.

Oak Ridge National Laboratory
Pollutant Assessments Group

Health and Safety

Procedures Manual
Sect. 15 Rev. 2

Date 6/92

Page 7 of 25

SUBJECT: EXOTOX MODEL 50 COMBUSTIBLE GAS INDICATOR (CGI)

\subsubsection{Battery-exhaustion alarm}

Ten minutes or more after the battery warning is displayed and the battery watchdog sounds (Sect. 15.2.5), the EXOTOX will give the battery-exhaustion alarm. This is signified by a constant audio tone and a display that is blank with the exception of the BAT legend.

A battery-exhaustion alarm takes priority over all other alarms and CANNOT be cancelled.

\subsubsection{Oxygen real-time alarm}

This occurs if the oxygen level measured by the EXOTOX falls outside one of the alarm points. Under these circumstances the standard alarm tone will sound and, depending on whether the atmosphere is oxygen enhanced or deficient, will display OXY HI or OXY LO. The oxygen channel LED will flash. Whatever operating mode the EXOTOX vias in prior to the detection of the alarm condition, the display will now indicate the percentage concentration of oxygen in the atmosphere.

This alarm can be cancelled.

\subsubsection{Hydrogen sulfide real-time alarm}

This occurs whenever the concentration of $\mathrm{H}_{2} \mathrm{~S}$ in the atmosphere exceeds the alarm point. The display will default to the $\mathrm{H}_{2} \mathrm{~S}$ display mode, and the standard alarm tone will sound. The display TOX legend lights up and the channel LED flashes.

This alarm can be cancelled.

\subsection{Carbon monoxide real-time alarm}

This occurs whenever the concentration levels of $\mathrm{CO}$ in the atmosphere exceed the alarm point. The display will default to the $\mathrm{CO}$ display mode, and the standard alarm tone will sound. The display TOX legend lights up, and the channel LED flashes.

This alarm can be cancelled. 
MARTIN MARIETTA

ENERGY SYSTEMS, INC.

Oak Ridge Nationai Laboratory
Pollutant Assessments Group

Health and Safety

Procedures Manual
Sect. 15 Rev. 2

Date 6/92

Page 8 of 25

SUBJECT: EXOTOX MODEL 50 COMBUSTIBLE GAS INDICATOR (CGI)

\subsection{Explosive real-time alarm}

Whenever the concentrations of explosive gases in the atmosphere exceed the alarm point, the display will default to the explosive gas display mode and the EXPLOSIVE ALARM TONE (Sect. 15.2.4.4) will sound. The display EXP legend lights up, and the channel LED flashes.

This alarm can be cancelled.

\section{CAUTION: HIGH OFF-SCALE READINGS MAY INDICATE AN EXPLOSIVE CONCENTRATION.}

\subsubsection{Hydrogen sulfide STEL alarm}

Whenever $\mathrm{H}_{2} \mathrm{~S}$ level in the previous $15 \mathrm{~min}$ is in excess of the alarm point and the alarm will sound. In this mode, the display defaults to the $\mathrm{H}_{2} \mathrm{~S}$ STEL display mode and the standard alarm tone sounds. The display STEL legend lights up, and the channel LED tlashes.

This alarm can be cancelled.

\subsection{Carbon monoxide STEL alarm}

Whenever the average exposure to $\mathrm{CO}$ in the previous $15 \mathrm{~min}$ is in excess of the alarm point, the display defaults to the CO STEL display mode and the standard alarm tone sounds. The display STEL legend lights up, and the channel LED flashes.

This alarm can be cancelled.

\subsection{Hydrogen sulfide TWA alarm}

This occurs when the total exposure to $\mathrm{H}_{2} \mathrm{~S}$ exceeds the alarm point in parts-permillion minutes. In this mode, the display defaults to the $\mathrm{H}_{2} \mathrm{~S}$ TWA display mode and the standard alarm tone sounds. The display TWA legend lights, and the channel LED flashes.

This alarm can be cancelled, but because the data store is not reset, the TWA alarm will reappear after the 30 -s time-out. 
MARTIN MARIETTA

ENERGY SYSTEMS, INC.

Oak Ridge National Laboratory
Pollutant Assessments Group

Health and Safety

Procedures Manual
Sect. 15 Rev. 2

Date 6/92

Page 9 of 25

SUBJECT: EXOTOX MODEL 50 COMBUSTIBLE GAS INDICATOR (CGI)

\subsection{Carbon monoxide TWA alarm}

This occurs when the total exposure to $\mathrm{CO}$ exceeds the alarm point in parts-permillion minutes. In this mode, the display defaults to the CO TWA display mode and the standard alarm tone sounds. The display TWA legend lights up, and the channel LED flashes.

This alarm can be cancelled, but because the data store is not reset, the TWA alarm will reappear after the 30 -s time-out.

\section{Wamings}

There are four types of warnings:

Battery warning. As the battery discharges, its output voltage drops. When a preset level is reached, the EXOTOX will give the operator a battery warning that tells the operator to change the battery within the next $10 \mathrm{~min}$ (dependent on the battery exhaustion). The BAT legend on the LCD will flash, and the WATCHDOG audio bleep will be followed by a longer bleep. The resultant "bip-bleep" will sound every $10 \mathrm{~s}$ to remind the operator to change the battery.

Overflow warning. When the EXOTOX measures a gas level in excess of the maximum display range specification, it goes into "overflow mode." In overflow mode, the display will read OFL, and the relevant annunciator/LED will light up. The speaker will sound the standard alarm tone or the explosive alarm tone. This alarm can be cancelled.

\section{CAUTION: A HIGH OFF-SCALE READING OR "OFL" IN THE EXPLOSIVE GAS MODE MAY INDICATE AN EXPLOSIVE CONCENTRATION.}

Underflow warnings. This warning is the same as an overflow warning, but levels below the minimum range specification are detected. Display indicates "UFL." This alarm can be cancelled.

Negative readings. When the EXOTOX measures one of the conditions shown in Table 15.2, it goes to "Negative Reading Mode," which indicates a loss of calibration. In this mode the display defaults to the relevant mode, and the speaker sounds a standard alarm tone or explosive alarm tone. This mode alarm can be cancelled. 
MARTIN MARIETTA ENERGY SYSTEMS, INC.

Oak Ridge National Laboratory
Pollutant Assessments Group

Health and Safety

Procedures Manual
Sect. 15 Rev. 2

Date 6/92

Page 10 of 25

SUBJECT: EXOTOX MODEL 50 COMBUSTIBLE GAS INDICATOR (CGI)

Table 15.2 Negative reading warning point

\begin{tabular}{ll}
\hline Carbon monoxide & Less than $-10 \mathrm{ppm}$ \\
Hydrogen sulfide & Less than $-5 \mathrm{ppm}$ \\
Explosive gas & Less than $-5 \%$ LEL \\
\hline \multicolumn{2}{c}{ WARNING: IN THE EVENT OF A FAULT } \\
INDICATION, LEAVE THE HAZARDOUS \\
AREA IMMEDIATELY AND INVESTIGATE \\
ALL FAULT INDICATIONS IN A SAFE AREA.
\end{tabular}

\subsubsection{Fault indications}

Battery fault. The most common fault in the EXOTOX is a discharged battery. The operator has a two-tier alarm system for this failure (Sect. 15.2.5). The EXOTOX 50 has a number of fault diagnosis circuits other than the battery warnings. A fault indication cannot be cancelled.

Oxygen fault. An electronics fault in the oxygen circuit (e.g., serious negative drift) will cause the EXOTOX to default to this oxygen mode. The display will read "FLt," the OXY and LO legends will light up, and the speaker will emit a continuous tone.

NOTE: ROUTINE SENSOR EXHAUSTION IS SIGNIFIED BY A STANDARD OXYGEN LOW ALARM, WHICH CONTINUOUSLY RETURNS EVEN WHEN THE INSTRUMENT IS IN FRESH AIR.

Explosive fault. An explosive gas sensor failure will cause the EXOTOX to default to the explosive fault mode. The display will read "FLt," the EXP legend will light up, ayd the speaker will emit a continuous tone.

WARNING: AN EXPLOSIVE FAULT ALARM MAY INDICATE A HIGHLY EXPLOSIVE GAS CONCENTRATION.

Reference fault. An electronics failure will cause the EXOTOX to default to the reference fault mode. The display will read "FLt," and the speaker will emit a continuous tone. Return the instrument for service. 
MARTIN MARIETTA

ENERGY SYSTEMS, INC.

Oak Ridge National Laboratory
Pollutant Assessments Group

Health and Safety

Procedures Manual
Sect. 15 Rev. 2

Date 6/92

Page 11 of 25

SUBJECT: EXOTOX MODEL 50 COMBUSTIBLE GAS INDICATOR (CGI)

\subsection{Standby Mode}

This is a mode of operation that allows the operator to take breaks without corrupting the accumulation of data for TWA calculations. While the instrument is in one of its normal operating modes or a cancelled alarm mode, it may be put into the standby mode.

To enter standby mode, depress and hold the SELECT button for at least $3 \mathrm{~s}$.

NOTE: As the button is depressed, the display will step to the next mode in the sequence. Ignore this and keep button depressed for $3 \mathrm{~s}$. While the instrument is in standby mode, the display will indicate "HLd," and the speaker will emit a standby watchdog bleep every $60 \mathrm{~s}$. All of the gas analysis and warning/fault functions continue to operate normally, and the STEL data accumulation continues. The TWA data accumulation does not continue but is not reset.

Apart from a low-battery warning, any alarm or fault state detected while the instrument is in standby mode causes the EXOTOX to revert to the normal alarm or fault mode associated with the condition detected. In the event of a low battery warning, the BAT legend will flash, and the single bleep watchdog will be replaced by the characteristic "bip-bleep" of the battery warning watchdog.

To return to the normal operating modes, depress and release the SELECT button. As the instrument leaves the standby mode, the STEL data store is reset unless the return is caused by an alarm condition.

To reset the STEL data store, enter the standby mode as detailed in the preceding and return to the normal operating mode.

\subsubsection{Data Recording}

Record data in the comment section on the PID monitoring form (Fig. 14.1). Turn over all field data forms to the CPM and copies to the SPM.

\subsection{Acoustic Earphone}

1. In high ambient noise conditions, such as those associated with pumping stations and wet wells, the normal audio alarm emitted by the EXOTOX 50 may not be heard. The acoustic earphone is an accessory designed for use in these conditions, alleviating the ambient noise problem. 
MARTIN MARIETTA

ENERGY SYSTEMS, INC.

Oak Ridge National Laboratory
Pollutant Assessments Group

Health and Safety

Procedures Manual
Sect. 15 Rev. 2

Date 6/92

Page 12 of 25

SUBJECT: EXOTOX MODEL 50 COMBUSTIBLE GAS INDICATOR (CGI)

2. The earpiece is held in place by a plastic loop. This loop may be reversed for use in either ear. The earpiece is connected to the EXOTOX via a plastic tube and a rubber plug. The tube may be cut to the length that best suits the individual operator.

3. For reasons of hygiene, Neotronics recommends that each operator has his/her own earpiece. If an earphone is to be reissued to a new user, ensure that it has been thoroughly cleaned and sterilized in a sterilizing solution. Always fit a new earpiece before reissue.

\subsection{Hand Aspirator}

1. This attachment allows work space atmospheres to be sampled without exposing the whole instrument to the working environment. The hand aspirator should be used if service ducts, surface trenches, supply pipes, etc., require gas testing.

2. Remove the aspirator grill attachment, aspirator bulb, and rubber hosing from the case, and snap the two moulding "tongues" into the recess on the EXOTOX sensor grill. Make sure that the aspirator hose is on the left side of the instrument when viewed from the display end.

3. Pump the aspirator three times in fresh air to ensure that the aspirator and sensor housing are free from retained gases. Check that the in-line filter is not obstructed; this is indicated by a slow return to normal shape after depressing the aspirator bulb.

4. When the sampling tube is inserted into the work space, always ensure that it is not in contact with standing liquids or solids that may be drawn into the tube.

\subsection{BATTERY MAINTENANCE}

\subsection{Removing Battery Pack}

The EXOTOX 50 is supplied with a custom battery pack. This rechargeable NiCad battery pack may be charged while it is either connected or disconnected from the EXOTOX. To disconnect the battery pack from the EXOTOX, use the following procedure:

\section{WARNING: DO NOT DISCONNECT, RECONNECT, OR RECHARGE THE BATTERY WHILE IN A HAZARDOUS ENVIRONMENT.}

1. Unscrew the captive locking screw on the EXOTOX using the hexagonal wrench supplied with the EXOTOX (2.5 mm A/F). 
MARTIN MARIETTA

ENERGY SYSTEMS, INC.

Oak Ridge National Laboratory
Pollutant Assessments Group

Health and Safety

Procedures Manual
Sect. 15 Rev. 2

Date 6/92

Page 13 of 25

SUBJECT: EXOTOX MODEL 50 COMBUSTIBLE GAS INDICATOR (CGI)

2. Rotate the battery pack through $90^{\circ}$, and then pull the battery pack away from the EXOTOX.

Before reconnecting the battery pack, make sure that the contacts on the battery pack and the EXOTOX are clean. To clean these contacts use cloth or paper towels.

\section{WARNING: UNDER NO CIRCUMSTANCES MUST ABRASIVE CLEANERS BE USED BECAUSE THIS WILL DAMAGE THE GOLD PLATING.}

3. To reconnect the battery pack, reverse the disconnection procedure and ensure that the keyway engages correctly with the slot in the top of the battery pack.

\subsubsection{Battery Pack Contacts}

Although the contacts are slightly recessed for protection against accidental shorting, care must be taken against shorting when the battery is disconnected from the EXOTOX. The recharging contacts on the base of the battery pack are electrically protected so that they cannot discharge of the battery. This is especially important if the battery pack is placed on a wet surface or is accidentally immersed.

\subsubsection{Charging the Battery}

1. It is essential that the correct charging conditions are maintained for extended NiCad battery life. For this reason, only a Neotronics battery charger must be used. The Neotronics battery charger is designed to provide a rapid recharge without the battery damage that is frequently caused by overcharging.

2. Before inserting the battery pack into the charger, ensure that the contacts are clean.

3. The battery pack (with or without the EXOTOX connected) may only be inserted in one position. Locators moulded into the charger case ensure correct orientation.

4. Press the battery pack firmly into the charging recess in the charger. The weight of the battery pack will ensure that there is sufficient contact pressure. As soon as contact is made, a red LED will light up, indicating "fast charge." If this light does not come on, remove the battery pack and check to make sure that the contacts are clean. Wait $10 \mathrm{~s}$ before returning battery pack to the sharger.

5. The battery will be fully recharged within $6 \mathrm{~h}$. When charged, the red "fast" LED will extinguish and a green "slow" LED will come on. The green LED indicates that the charger is not "trickle charging" the battery. 
MARTIN MARIETTA

ENERGY SYSTEMS, INC.

Oak Ridge National Laboratory
Pollutant Assessments Group

Health and Safety

Procedures Manual
Sect. 15 Rev. 2

Date 6/92

Page 14 of 25

SUBJECT: EXOTOX MODEL 50 COMBUSTIBLE GAS INDICATOR (CGI)

6. For extended battery life, it is recommended that the battery pack be fully discharged from time to time. To achieve this, connect the battery to an EXOTOX (switched on) until the battery exhaustion alarm sounds. Then charge the battery until it is fully charged. This Discharge/Charge Cycle will prevent memory problems (reduced capacity characteristic) of mistreated NiCad batteries.

\subsubsection{Battery Replacement}

To comply with international intrinsic safety standards, the EXOTOX battery pack is a sealed, encapsulated unit; no attempt must be made to remove the batteries from the pack. Any such action will invalidate both the Neotronics guarantee and the intrinsic safety certification.

\subsubsection{Intrinsic Safety Requirements}

Never allow battery packs to be changed or recharged in hazardous atmospheres or by unauthorized personnel.

\subsection{POSTOPERATION}

Decontaminate or clean instrument as needed. If decontamination is required, follow the procedures specified in Sect. 5.6. If cleaning is required, refer to the operating manual.

1. Case. The EXOTOX 50 Personal Gas Monitor is built into a heavy-duty shockresistant case. This case should be wiped occasionally with a clean, damp cloth or paper towel. Do not use solvent or proprietary cleaners, which may damage the moulding material.

2. Grill. The sensor grill is designed to protect the instrument's sensors without restricting the airflow. Check to confirm that the grill is clean and unobstructed at all times.

3. Straps. Check that the carrying straps and their attachment points are clean and fit for use at all times.

4. Storage. When the EXOTOX is not in use, it should be stored in a cool, dry room, either on a rack or hung by the carrying straps. The EXOTOX may be kept on charge when not in use. 
MARTIN MARIETTA

ENERGY SYSTEMS, INC.

Oak Ridge National Laboratory
Pollutant Assessments Group

Health and Safety

Procedures Manual
Sect. 15 Rev. 2

Date $6 / 92$

Page 15 of 25

SUBJECT: EXOTOX MODEL 50 COMBUSTIBLE GAS INDICATOR (CGI)

- Toxic gas sensors: $\mathrm{H}_{2} \mathrm{~S}$ sensors and $\mathrm{CO}$ sensors have an average life expectancy of 2 years. It must be noted that toxic sensors do not provide an electrical output when exposed to fresh air and, therefore, are not fail safe. Toxic sensors may be verified by the application of test gases.

- Explosive gas sensors: Explosive gas sensors (Pellistors) have an average life expectancy of 3 years.

- Oxygen sensors: Electrochemical oxygen sensors have a life expectancy of 12 months.

- Humidity effects: Oxygen sensor calibration is affected by the relative humidity. Errors seen when the instrument is exposed to dry bottled gases may be the result of humidity effects. EXOTOX Model 50 instruments must not be calibrated in extreme environmental conditions.

- Accuracy in limited atmospheres: (1) Leaded gasoline vapors in the tested atmosphere can destroy the instrument's sensitivity. The instrument manufacturer's operating manual should be consulted to determine its function in leaded gasoline atmospheres. (2) Oxygen-deficient atmospheres may not indicate the true concentrations of combustible gas. (3) Unusually high concentrations of sulfur dioxide, fluorine, chlorine, bromine, iodine, and oxides of nitrogen cause measurement interference.

\subsection{ANNUAL CALIBRATION}

The performance of the EXOTOX Model 50 shall be checked once every 3 months and recalibrated if necessary. The instrument must be calibrated once a year.

\subsubsection{Performance Check}

To fully test the operation of the EXOTOX Model 50, the technician must perform two separate tasks: a functional test of the electronics and a gas calibration check.

Gas calibration checks are performed using standard gas bottles. Use of a gas calibration kit, which is supplied with the EXOTOX and simplifies calibration checks and adjustments, is recommended. Always check to make sure that the stated concentration of the test gas used is accurate. 
MARTIN MARIETTA

ENERGY SYSTEMS, INC.

Oak Ridge National Laboratory
Pollutant Assessments Group

Health and Safery

Procedures Manual
Sect. 15 Rev. 2

Date 6/92

Page 16 of 25

SUBJECT: EXOTOX MODEL 50 COMBUSTIBLE GAS INDICATOR (CGI)

\subsubsection{Equipment Requirements}

The following equipment is needed for EXOTOX 50 performance checks and calibration.

Digital voltmeter to read 4 to $6 \mathrm{~V}$ dc resolution $0.05 \mathrm{~V}$

Aspirator head part No. 008-0065-05

FOR CALIBRATION ONLY

Hex wrench (Allen Key) 2 mm (supplied with EXOTOX)

Calibration tool supplied with EXOTOX

FOR CALIBRATION AND PERFORMANCE CHECKS

Test Gas 1 (carbon monoxide) $725 \mathrm{ppm}+25 \mathrm{ppm}$ (in air)

Test Gas 2 (methane) $1.15 \%+0.1 \%$ vol (in air)

Test Gas 3 (hydrogen sulfide) 80 ppm +5 ppm (in nitrogen)

\subsubsection{Functional Check}

1. Connect a fully charged battery to the EXOTOX Model 50.

2. Switch the instrument on. The display will momentarily indicate a software code. The display will now flash all segments and legends seven times. The four LEDs will flash ten times. At the same time the LEDs flash, the speaker will emit a bleep. At the end of this SELF-TEST sequence, the display will default to the Oxygen Display Mode, and the $\mathrm{O}_{2}$ LED and the display OXY legend will illuminate.

3. Depress the SELECT button once (momentarily). The speaker will emit a bleep as the button is pressed. The display legend TOX will illuminate. The CO LED will illuminate.

NOTE: The speaker will emit a bleep once every $10 \mathrm{~s}$ as long as the instrument is switched on.

4. Depress the SELECT button once (momentarily). The speaker will emit a bleep as the button is pressed. The CO LED will remain illuminated. The STEL legend will illuminate.

5. Again, depress the SELECT button momentarily, listen for a bleep as the button is pressed. The CO LED will remain illuminated. The STEL legend will illuminate. 
MARTIN MARIETTA ENERGY SYSTEMS, INC.

Oak Ridge National Laboratory
Pollutant Assessments Group

Health and Safety

Procedures Manual
Sect. 15 Rev. 2

Date 6/92

Page 17 of 25

SUBJECT: EXOTOX MODEL 50 COMBUSTIBLE GAS INDICATOR (CGI)

6. Depress the SELECT button once (momentarily), listen for a bleep as the button is pressed. The display legend TOX will illuminate. The $\mathrm{H}_{2} \mathrm{~S}$ LED will illuminate.

7. Depress the SELECT button once (momentarily). Again, the speaker will emit a bleep as the button is pressed, and the $\mathrm{H}_{2} \mathrm{~S}$ LED will remain illuminated. The TWA legend will illuminate.

8. Depress the SELECT button once (momentarily) and confirm a bleep from the speaker as the button is pressed. The $\mathrm{H}_{2} \mathrm{~S}$ LED will remain illuminated, and the STEL legend will illuminate.

9. Depress the SELECT button once (momentarily), and listen for the speaker to emit a bleep as the button is pressed. The EXP LED and the display EXP legend will illuminate.

10. Depress the SELECT button once (momentarily). The speaker will emit a bleep as the button is pressed. The display will alternate between an alphanumeric indication of " $\mathrm{Hr}$," and an indication of the time elapsed since the instrument was first switched on (e.g., 0.2).

11. Cover the display panel with a hand, and depress and hold the BACKLIGHT button. The display will illuminate from a light at either end.

12. Depress and hold the SELECT button for $3 \mathrm{~s}$ (slow count). The display will indicate "HTd." The speaker will emit a bleep once every $60 \mathrm{~s}$.

13. Breathe into the sensor grill. The instrument will leave the hold mode and default to the Oxygen Display Mode. The display will indicate less than $19.0 \%$. The OXY and LO legends will light, the speaker will emit the pulsing alarm tone, and the $\mathrm{O}_{2}$ LED will flash. Depress and hold down the SELECT button for $3 \mathrm{~s}$. The alarm tone will cease and the LO legend will extinguish. The speaker will now emit a double bleep every $10 \mathrm{~s}$.

14. Switch off the EXOTOX.

\subsubsection{Gas calibration check}

If any doubt about the performance of the EXOTOX 50 is raised while these checks are carried out, the recalibration procedure in Sect. 15.6.2 must be performed.

If a parameter is found to be out of tolerance, the technician must go to the section dealing with its recalibration, perform the recalibration, and return to the next calibration check in the sequence.

1. Switch the EXOTOX on in fresh air (with a fully charged battery).

2. Check to make sure that the display indicates $20.9 \%$ oxygen $+0.2 \%$, (Sect. 15.6.2.1).

3. Connect the aspirator attachment, apply Test Gas 1, and start stopwatch.

4. In less than $90 \mathrm{~s}$ the instrument will have a $\mathrm{CO}$ real-time alarm (Sect. 15.6.2.2). 
NOTE: When GAS 1 is applied to the EXOTOX a number of alarms other than those detailed in the preceding will occur. In many cases the $\mathrm{H}_{2} \mathrm{~S}$ real-time alarm will activate first. This must be cancelled and ignored. $\mathrm{H}_{2} \mathrm{~S}$ and $\mathrm{CO}$ STEL alarms may also occur and must also be cancelled and ignored. The $\mathrm{H}_{2} \mathrm{~S}$ alarms are caused by inherent sensor cross-sensitivities, which may cause readings up to $108 \mathrm{ppm} \mathrm{H}_{2} \mathrm{~S}$.

5. Switch off Test Gas 1. Switch off the EXOTOX 50. Remove the aspirator attachment from the instrument. Disconnect Test Gas 1 from the calibration setup and substitute Test Gas 3.

6. Place the EXOTOX in a fresh-air environment. Wait $3 \mathrm{~min}$. Switch on the EXOTOX 50.

7. Apply Test Gas 3 to the instrument through the aspirator attachment, and start the stopwatch.

8. The EXOTOX will first enter the OXY LO alarm mode.

9. In less than $90 \mathrm{~s}$, the EXOTOX will also have a $\mathrm{H}_{2} \mathrm{~S}$ real-time alarm (Sect. 15.2.4.7).

NOTE: When GAS 3 is applied to the EXOTOX, a number of alarms other than those detailed here will occur. CO STEL and/or CO real-time alarms may activate as a result of sensor cross-sensitivities. These alarms must be cancelled and ignored.

10. Switch off Test Gas 3. Switch off the EXOTOX 50. Remove the aspirator attachment, disconnect Test Gas 3 from the calibration setup, and substitute Test Gas 2.

11. Place the EXOTOX in a fresh-air environment. Wait 3 minutes. Switch on the EXOTOX 50.

12. Apply Test Gas 2 to the instrument via the aspirator attachment and start the stopwatch.

13. Instruments set for $20 \%$ LEL or $1.0 \%$ volume alarm points will enter the explosive alarm mode within $60 \mathrm{~s}$. Instruments set for $10 \% \mathrm{LEL}$ or $0.5 \%$ volume alarm points will enter the alarm mode within $30 \mathrm{~s}$ (Sect. 15.2.4.9).

14. Switch off Test Gas 2. Switch off the EXOTOX 50. Disconnect Test Gas 2.

\subsubsection{Ga Calibration Adjustments}

This section must be used only in conjunction with Sect. 15.5.1. Each part of the following instructions refers to that section. A CGI equipment checklist is provided on Fig. 15.1. 
MARTIN MARIETTA

ENERGY SYSTEMS, INC.

Oak Ridge National Laboratory
Pollutant Assessments Group

Health and Safety

Procedures Manual
Sect. 15 Rev. 2

Date 6/92

Page 19 of 25

SUBJECT: EXOTOX MODEL 50 COMBUSTIBLE GAS INDICATOR (CGI)

1. CGI Manufacturer: Neotronics

Model 50

2. Earphone extension

3. Replacement earpieces

4. Aspirator attachment

5. Oxygen sensor

6. Hydrogen sulfide sensor

7. Carbon monoxide sensor

8. NiCad battery pack

9. Replacement harness

10. Single way battery charger

13. 4-way battery charger

12. Box of filters for aspirator attachment

13. EXOTOX Model 50 OFCH user card

14. EXOTOX Model 50 OFCH user manual

15. Jeweler's screwdrivers for internal adjustments

16. Calibration Kit

A) Spare gas cylinder (gas)

B) Valve attachment

C) 1/4 "Flexible tubing

D) Cylinder to encapsulate sensor probe

17. Field Data Forms

Fig. 15.1. Combustible gas indicator equipment checklist.

ONLY AUTHORIZED AND QUALIFIED PERSONNEL MUST ATTEMPT RECALIBRATION. ATTEMPTS AT CALIBRATION BY UNAUTHORIZED STAFF WILL INVALIDATE SAFETY CERTIFICATIONS AND THE WARRANTY:

\section{ALL GAS CALIBRATION MUST BE PERFORMED OUT-OF-DOORS OR IN A} WELL-VENTILATED ENVIRONMENT (e.g., FUME HOOD).

EXOTOX Model 50 instruments must not be calibrated in extreme environmental conditions.

WARNING: Humidity effects. Oxygen sensor calibration is affected by relative humidity. Errors seen when the instrument is exposed to dry bottled 
MARTIN MARIETTA

ENERGY SYSTEMS, INC.

Oak Ridge National Laboratory
Pollutant Assessments Group

Health and Safety

Procedures Manual
Sect. 15 Rev. 2

Date $6 / 92$

Page 20 of 25

SUBJECT: EXOTOX MODEL 50 COMBUSTIBLE GAS INDICATOR (CGI)

gases may be caused by humidity effects. Wherever possible the instrument must be calibrated in conditions similar to the work place.

Remove the calibration panel from the top of the instrument using the 2-mm hex wrench supplied with the EXOTOX.

\subsubsection{Oxygen calibration}

1. Switch the EXOTOX on in fresh air and allow the instrument to settle.

2. Adjust the OXY SPAN potentiometer until the display indicates $20.9 \%+0.1 \%$. If this cannot be achieved, send the instrument for service.

3. Return to the performance check (Sect. 15.5.1).

\subsubsection{Carbon monoxide calibration}

1. Connect the calibration setup using Test Gas 1.

2. Switch the EXOTOX on in fresh air. SELECT the CO real-time-display mode. Slowly adjust the CO ZERO potentiometer until the display reads $0 \mathrm{ppm}+1$ ppm. If this cannot be achieved, return the instrument for service.

3. Connect the aspirator attachment to the EXOTOX with the polarization arrow pointing toward the rear of the instrument.

4. Flow Test Gas 1 through the calibration setup for at least $5 \mathrm{~min}$. The instrument may show $\mathrm{H}_{2} \mathrm{~S}$ and $\mathrm{CO}$ alarms, which must be cancelled. Once more SELECT the $\mathrm{CO}$ real-time display and wait for the display to settle, recancelling alarms when necessary.

5. Slowly adjust the CO SPAN potentiometer to the $\mathrm{CO}$ value written on the calibration certificate ( \pm 1 point). If this cannot be achieved, send the instrument for service.

6. Turn off the test gas, disconnect the aspirator attachment and return to the performance check (Sect. 15.5.1).

\subsubsection{Hydrogen sulfide calibration}

1. Connect the calibration setup with Test Gas 3.

2. Switch the EXOTOX on in fresh sir. SELECT the $\mathrm{H}_{2} \mathrm{~S}$ real-time display mode. Slowly adjust the $\mathrm{H}_{2} \mathrm{~S}$ Zero potentiometer until the display reads $0 \mathrm{ppm}+1$ ppm. If this cannot be achieved, send the instrument for service.

3. Connect the aspirator attachment to the EXOTOX with the polarization arrow pointing toward the front of the instrument. 
MARTIN MARIETTA ENERGY SYSTEMS, INC.

Oak Ridge National Laboratory
Pollutant Assessments Group

Health and Safety

Procedures Manual
Sect. 15 Rev. 2

Date 6/92

Page 21 of 25

SUBJECT: EXOTOX MODEL 50 COMBUSTIBLE GAS INDICATOR (CGI)

4. Flow Test Gas 3 through the Calibration Setup for at least $15 \mathrm{~min}$. The instrument will show oxygen and $\mathrm{H}_{2} \mathrm{~S}$ alarms, which must be cancelled. After 15 min, cancel all alarms and SELECT the $\mathrm{H}_{2} \mathrm{~S}$ real-time display mode. Wait for the display to settle.

5. Slowly adjust the $\mathrm{H}_{2} \mathrm{~S}$ SPAN potentiometer until the display reads the same as the $\mathrm{H}_{2} \mathrm{~S}$ value written on the calibration certificate ( $\left.\pm 1 \mathrm{ppm}\right)$. If this cannot be achieved, send the instrument for service.

6. Turn off the test gas, disconnect the aspirator attachment, and return to performance check (Sect. 15.5.1).

\subsection{Explosive test gas calibration (methane)}

1. Connect the calibration setup with Test Gas 2.

2. Switch the EXOTOX on in fresh air. SELECT the explosive test gas display mode. Slowly adjust the EXP ZERO potentiometer until the display reads $0 \%$ $\pm 1 \%$ LEL. If this cannot be achieved, send the instrument for service.

3. Connect the aspirator attachment to the EXOTOX with the polarization arrow pointing toward the front of the instrument.

4. Flow Test Gas 2 through the calibration setup for at least $5 \mathrm{~min}$. The instrument will show an explosive gas alarm, which must be cancelled. After 5 min, cancel all alanus and SELECT the explosive test gas display mode. Wait for the display to settle.

5. Slowly adjust the EX SPAN potentiometer until the display reads the same as the calculated \%LEL value written on the calibration certificate ( $\pm 1 \%$ LEL). If this cannot be achieved, send the instrument for service.

6. Turn off the test g8s, disconnect the aspirator attachment, and return to performance check (Sect. 15.5.1).

\subsection{Recording COI office calibration}

Necessary calibration data to be recorded in the office logbook include

1. Date and time of entry.

2. Site identification.

3. Instrument, model number, and serial number.

4. Calibration gas used.

5. Name of the instrument calibration technician. 
MARTIN MARIETTA

ENERGY SYSTEMS, INC.

Oak Ridge National Laboratory
Pollutant Assessments Group

Health and Safety

Procedures Manual
Sect. 15 Rev. 2

Date 6/92

Page 22 of 25

SUBJECT: EXOTOX MODEL 50 COMBUSTIBLE GAS INDICATOR (CGI)

Table 15.3 lists the display interpretation for the Exotox Model 50 CGI, Table 15.4 lists the alphanumeric display indications, and Table 15.5 lists the relative sensitivities to explosive and flammable gases.

Table 153. Display interpretation for the Erotox Model 50 CGI

\begin{tabular}{lll}
\hline LED LIT & \multicolumn{1}{c}{ Legend(s) LIT } & \multicolumn{1}{c}{ Reading or alarm } \\
\hline $\mathrm{H}_{2} \mathrm{~S}$ & TOX \& PPM & Hydrogen sulfide, real-time \\
$\mathrm{H}_{2} \mathrm{~S}$ & TOX, STEL, \& PPM & Hydrogen sulfide, short-term exposure limit \\
$\mathrm{H}_{2} \mathrm{~S}$ & TOX, TWA, \& PPM & Hydrogen sulfide, time-weighted average \\
$\mathrm{CO}$ & TOX \& PPM & Carbon monoxide, real-time \\
$\mathrm{CO}$ & TOX, STEL, \& PPM & Carbon monoxide, short-term exposure limit \\
$\mathrm{CO}$ & TOX, TWA, \& PPM & Carbon monoxide, time-weighted average \\
$\mathrm{O}_{2}$ & OXY \& \% & Oxygen, real-time \\
$\mathrm{O}_{2}$ & OXY, LO, \& \% & Oxygen, low alarm \\
$\mathrm{O}_{2}$ & OXY, HI, \& \% & Oxygen, high alarm \\
EXP & EXP \& \% & Explosive, real-time \\
None & BAT \& other & Battery warning \\
None & BAT (flashing) & Battery exhaustion alarm \\
\hline
\end{tabular}


MARTIN MARIETTA

ENERGY SYSTEMS, INC.

Oak Ridge National Laboratory
Pollutant Assessments Group

Health and Safety

Procedures Manual
Sect. 15 Rev. 2

Date 6/92

Page 23 of 25

\section{SUBJECT: EXOTOX MODEL 50 COMBUSTIBLE GAS INDICATOR (CGI)}

Table 15.4. Alphanumeric display indications for the Exotox Model 50 CGI

\begin{tabular}{lll}
\hline Display & \multicolumn{1}{c}{ Legend(s) LIT } & \multicolumn{1}{c}{ Interpretation } \\
\hline FLt & OXY \& LO or HI & Oxygen fault \\
FLt & EXP & Explosive fault \\
FLt & None & Reference fault \\
OFL & EXP & Explosive overflow \\
OFL & OXY & Oxygen overflow \\
OFL & TOX & Hydrogen sulfide or carbon monoxide \\
& & Overflow (LED signifies which) \\
UFL & EXP & Explosive underflow \\
UFL & OXY & Oxygen underflow \\
UFL & TOX & Hydrogen sulfide or carbon monoxide \\
& & Underflow (LED signifies which) \\
HLd & None & Standby mode \\
\hline
\end{tabular}


MARTIN MARIETTA

ENERGY SYSTEMS, INC.

Oak Ridge National Laboratory
Pollutant Assessments Group

Health and Safety

Procedures Manual
Sect. 15 Rev. 2

Date 6/92

Page 24 of 25

SUBJECT: EXOTOX MODEL 50 COMBUSTIBLE GAS INDICATOR (CGI)

Table 15.5. Relative sensitivity to explosive and flammable gases

(for instruments calibrated with $20 \%$ LEL of methane in air)

\begin{tabular}{|c|c|c|c|}
\hline \multirow{2}{*}{ Gas or vapor } & \multicolumn{2}{|c|}{$\begin{array}{l}\text { Concentration applied } \\
\text { for a display indication } \\
\text { of } 20 \% \text { LEL }\end{array}$} & \multirow{2}{*}{$\begin{array}{c}\text { Specific } \\
\text { gravity of } \\
\text { gas at } 20^{\circ} \mathrm{C}\end{array}$} \\
\hline & $\%$ LEL & VOL\% & \\
\hline Acetic acid & 36.8 & 2.00 & 2.10 \\
\hline Acetone & 38.3 & 1.00 & 2.03 \\
\hline Acetylene & 35.2 & 0.88 & 0.91 \\
\hline \multicolumn{4}{|l|}{ Air } \\
\hline Ammonia & 15.8 & 2.53 & 0.59 \\
\hline Benzene & 40.0 & 0.64 & 2.73 \\
\hline n-Butane & 34.0 & 0.65 & 2.03 \\
\hline n-Decane & 61.0 & 0.49 & 4.97 \\
\hline Diphenyl & 80.0 & 0.48 & 1.33 \\
\hline Ethylene alcohol & 27.4 & 0.90 & 1.61 \\
\hline Ethylene oxide & 38.6 & 1.16 & 1.54 \\
\hline n-Heptane & 51.8 & 0.52 & 3.50 \\
\hline Hydrogen & 26.0 & 1.04 & 0.07 \\
\hline Methane & 20.0 & 1.06 & 0.56 \\
\hline Methyl alcohol & 23.2 & 1.69 & 1.12 \\
\hline Propane & 36.2 & 0.80 & 1.54 \\
\hline Toluene & 49.4 & 0.82 & 3.22 \\
\hline Trimethylamine & 41.2 & 0.82 & 2.06 \\
\hline Xylene & 51.0 & 0.56 & 3.70 \\
\hline
\end{tabular}


MARTIN MARIETTA

ENERGY SYSTEMS, INC.

Oak Ridge National Laboratory
Pollutant Assessments Group

Health and Safety

Procedures Manual
Sect. 15 Rev. 2

Date 6/92

Page 25 of 25

SUBJECT: EXOTOX MODEL 50 COMBUSTIBLE GAS INDICATOR (CGI)

\subsection{REFERENCES}

Code of Federal Regulations-29, Pt. 1900-1910, 7/87.

Code of Federal Regulations-30, Pt. 1-199, 1986.

Code of Federal Regulations-40, Pt. 150-189, 7/86.

EPA. 1981. Health and safety requirements for employees engaged in field activities. Environmental Protection Agency Order 1440.1. U.S. Environmental Protection Agency, July 12, 1981.

EXOTOX Model 50 Combustible Gas/Oxygen Monitor Instruction Manual. Manufactured by Neotronics, N.A., Inc., Gainesville, Georgia 30503.

NIOSH. 1985. Occupational safety and health guidance manual for hazardous waste site activities. National Institute for Occupational Safety and Health, Occupational Safety and Health Administration, U.S. Coast Guard, and Environmental Protection Agency, DHHS (NIOSH) Publication 85-115, October 1985. 
MARTIN MARIETTA

ENERGY SYSTEMS, INC.

Oak Ridge National Laboratory
Pollutant Assessments Group

Health and Safety

Procedures Manual
Sect. 16 Rev. 2

Date 6/92

Page 1 of 21

SUBJECT: GASTECH MODEL GX-86 COMBUSTIBLE GAS INDICATOR (CGI)

\section{GASTECH MODEL GX-86 COMBUSTIBLE GAS INDICATOR (CGI)}

\subsection{PURPOSE}

To describe the equipment and procedures for monitoring combustible gas levels to ensure a safe working environment.

\subsection{APPLICABILITY}

This instrument is designed and intended for personnel safety in entering or occupying potentially hazardous confined spaces that may contain hazardous gases (which include all normal hydrocarbons and combustible gases, except for hydrogen and acetylene). The instrument is certified to be intrinsically safe against initiation of explosion when used in such environments.

\subsubsection{Specifications}

$\begin{array}{lllll}\text { Gas } & \text { Range } & \text { Low alarm } & & \text { High alarm } \\ \text { Combustibles } & 0-100 \% \text { LEL } & 20 \% \text { LEL } & & 50 \% \text { LEL } \\ \text { Oxygen } & 0-40 \% & 19.5 \% & & 25.0 \% \\ \mathrm{H}_{2} \mathrm{~S} & 0-100 \mathrm{ppm} & 10 \mathrm{ppm} & & 30 \mathrm{ppm} \\ \mathrm{CO} & 0-300 \mathrm{ppm} & 50 \mathrm{ppm} & & 100 \mathrm{PPM}\end{array}$

Use of the Gastech instrument in acetylene or hydrogen environments requires special consideration. Likewise, use of the instrument in oxygen-enriched atmosphere is beyond the normal scope of its intended application.

Do not attempt to use in oxygen-acetylene mixtures as found in oxyacetylene welding and cutting equipment.

Humidity: 0-99\% RH (noncondensing)

Operating: $-15^{\circ} \mathrm{C}\left(5^{\circ} \mathrm{F}\right)+50^{\circ} \mathrm{C}\left(120^{\circ} \mathrm{F}\right)$

Battery capacity: Minimum $7 \mathrm{~h}$ (typically $10 \mathrm{~h}$ ) 
MARTIN MARIETTA ENERGY SYSTEMS, INC.

Oak Ridge National Laboratory
Pollutant Assessments Group

Health and Safery

Procedures Manual
Sect. 16 Rev. 2

Date 6/92

Page 2 of 21

SUBJECT: GASTECH MODEL GX-86 COMBUSTIBLE GAS INDICATOR (CGI)

\subsection{INSTRUMENT DESCRIPTION}

The Model GX-86 Personal Four-Way Gas Alarm is a portable, automatic microprocessor-controlled instrument. It is used to detect combustibles, oxygen deficiency, $\mathrm{H}_{2} \mathrm{~S}$, and $\mathrm{CO}$. As a personal instrument, it may be carried by means of a belt loop or a shoulder strap, leaving the hands free for normal work. It is fully automatic, self-adjusting, and, when preset levels of oxygen deficiency or presence of combustible, $\mathrm{CO}$, or $\mathrm{H}_{2} \mathrm{~S}$ gas are detected, it will give characteristic warnings. It can detect and indicate combustible concentrations to the LEL, $\mathrm{H}_{2} \mathrm{~S}$ concentrations up to $100 \mathrm{ppm}$, or $\mathrm{CO}$ concentrations up to $300 \mathrm{ppm}$ and analyzes for oxygen over a range of 0 to $40 \%$.

This instrument also contains a special microprocessor program, which will present at any time the average of the $\mathrm{H}_{2} \mathrm{~S}$ or $\mathrm{CO}$ exposure accumulated since the time the instrument was last turned on. After the ON switch is pressed and the preliminary cycle is complete, the program will collect and store the exposure of $\mathrm{H}_{2} \mathrm{~S} / \mathrm{CO}$. Each time an exposure occurs, it is added to all previous exposures. When the display command is given, the program will divide the stored accumulation by the elapsed time, and the display will show the TWA in parts per million $\mathrm{H}_{2} \mathrm{~S} / \mathrm{CO}$, as well as the elapsed time.

If for any reason the oxygen concentration should exceed $25 \%$, an alarm is given to warn of potential fire hazard.

\subsubsection{Detection}

Detection is by a diffusion head mounted on the bottom of the instrument, which alternatively may be used on an optional extension cable. The head is attached to the instrument by means of a 12-pin connector. Mounted within the diffusion head are four separate and distinct plug-in detectors. The combustibles detector uses a catalytic element and a reference element as half of a Wheatstone bridge circuit; the $\mathrm{H}_{2} \mathrm{~S}, \mathrm{CO}$, and oxygen detectors use an electrochemical cell. The instrument has sufficient battery capacity to operate for $10 \mathrm{~h}$, and it includes warning statement features to notify the user of any malfunction.

\subsection{Controls and Indicators}

The instrument is turned on at the touch of switch pads; however, sustained pressure on the OFF pad for $5 \mathrm{~s}$ is required to turn it off. Adjustments for zero combustibles, CO, and $\mathrm{H}_{2} \mathrm{~S}$ are automatic but only when the appropriate combination of buttons is pressed. This precludes unintentional, incorrect adjustment in a contaminated background. 
MARTIN MARIETTA

ENERGY SYSTEMS, INC.

Oak Ridge National Laboratory
Pollutant Assessments Group

Health and Safety

Procedures Manual
Sect. 16 Rev. 2

Date $6 / 92$

Page 3 of 21

SUBJECT: GASTECH MODEL GX-86 COMBUSTIBLE GAS INDICATOR (CGI)

\subsection{DETAILED DESCRIPTION}

\subsubsection{Housing}

The Model GX-86 is housed in a rigid plastic case that is durable and shock-resistant. The detectors are protected by a snap-on slotted metal enclosure on the bottom end. Opposite the diffusion head at the top is the control panel and display, canted slightly for ease of operation and visibility while in its carrying case.

The instrument is carried in a leather case that has openings to expose the control panel, the detectors, the buzzer grill, the remote buzzer, and earphone jacks. The case includes a leather strap loop for carrying on a belt, and the instrument includes metal loops for attaching a shoulder strap.

\subsubsection{Combustible Gas Detector}

The combustible gas sensitive detector is a replaceable plug-in assembly that is installed within a cylindrical metal shell that has a perforated cap. The detector is retained in diffusion head by means of bayonet-style base.

The active detector element is of the platinum catalyst type, and an electrically identical but noncatalytic reference element mounted in the same environment serves to stabilize the measurement and compensate for effects of noncombustible gases, temperature variations, etc. The elements are protected by a stainless steel sintered metal flame arrestor, which permits access of surrounding atmosphere but prevents outward propagation of flame should an explosive atmosphere be sampled. The flame arrestor also acts as a diffuser to isolate elements from flow fluctuations.

The detector assembly connects electrically to the diffusion head by means of four pins at the base of the detector.

\subsubsection{Carbon Monoxide and Hydirogen Sulfide Detectors}

The $\mathrm{CO}$ and $\mathrm{H}_{2} \mathrm{~S}$ detectors are also of the bayonet type and are externally identical except for their labels, which indicate the gas to which the detector is sensitive. The detectors are assembled into a cylindrical plastic case that has a contact point at one end and a perforated disc at the other end to allow the surrounding atmosphere to diffuse into the active face. The $\mathrm{CO}$ detector has a slip-on charcoal filter covering the perforated disc, held in place by a rubber retainer, to eliminate interference from $\mathrm{H}_{2} \mathrm{~S}$. 
MARTIN MARIETTA

ENERGY SYSTEMS, INC.

Oak Ridge National Laboratory
Pollutant Assessments Group

Health and Safery

Procedures Manual
Sect. 16 Rev. 2

Date 6/92

Page 4 of 21

SUBJECT: GASTECH MODEL GX-86 COMBUSTIBLE GAS INDICATOR (CGI)

Gas detection occurs in an electrochemical cell consisting of two metal electrodes in an acid electrolyte, covered by a permeable fluorocarbon membrane. Gas in the atmosphere surrounding the perforated face of the detector diffuses through the membrane at a rate proportional to its partial pressure. The gas enters into an electrochemical reaction that produces a current directly proportional to its concentration, and this current in turn is amplified in the instrument circuitry to produce a reading in parts per million and to trigger alarms at preset points. To keep a stabilized sensitivity, these cells have a regulated bias voltage applied whether or not the instrument is energized.

This detector is connected electrically by means of bayonet retaining pins.

\subsubsection{Oxygen Detector}

The oxygen detector is a plug-in cell assembly in a metal enclosure in which pins retain the detector in a bayonet-type socket. The shell forms one electrical contact, and an insulated button at the bottom end makes the other contact. A perforated metal guard at the top end allows the surrounding atmosphere to diffuse in and reach the active part of the cell.

Oxygen detection occurs in an electrochemical cell consisting of a gold and a lead electrode in an alkaline electrolyte, covered by a fluorocarbon membrane. Oxygen in the atmosphere surrounding the detector diffuses through the membrane at a rate proportional to the partial pressure of oxygen.

This oxygen enters into an electrochemical reaction that produces a current directly proportional to the oxygen concentration; this current in turn develops a voltage across a temperature-compensating thermistor/resistor network. The voltage is applied to the detector terminals and, hence, to the instrument circuitry where it produces a reading in percent oxygen and triggers alarms at preset points.

\subsubsection{Display}

Instrument indicators are presented on a dot matrix liquid crystal display on the top face of the instrument. The display reads combustible gas, oxygen, $\mathrm{H}_{2} \mathrm{~S}$, and $\mathrm{CO}$ concentrations simultaneously.

As the instrument steps through its automatic turn-on sequence, the display indicates the steps being taken and the results. At the end of the sequence, a double tone sounds. 
MARTIN MARIETTA

ENERGY SYSTEMS, INC.

Oak Ridge National Laboratory
Pollutant Assessments Group

Health and Safety

Procedures Manual
Sect. 16 Rev. 2

Date 6/92

Page 5 of 21

SUBJECT: GASTECH MODEL GX-86 COMBUSTIBIEE GAS INDICATOR (CGI)

At a particular command, the display will show the results of the $\mathrm{H}_{2} \mathrm{~S}$ and $\mathrm{CO}$ accumulation since the last turn-on.

A photodiode light sensor located at the upper left of the display controls the illumination of the display. As the available light lessens, LED lights that illuminate the display will turn on.

\subsubsection{Controls and Indicators}

Table 16.1 details the indicators for Model GX-86. The control panel contains the display, four alarm lights, and five switches. Use of the touch-type switches allows the panel to be flat, avoiding the use of protruding light lenses or switch handles that could be inadvertently activated or damaged.

\subsubsection{Power}

Power ON/OFF switch positions have momentary push-button action. Pressing the ON position applies power to the instrument, sounds a single tone, and starts it through its automatic preparatory sequence. When the sequence is complete, a double tone will sound and the display will show $00 \%$ LEL combustibles, $20.9 \%$ oxygen, $00 \mathrm{ppm} \mathrm{H}_{2} \mathrm{~S}$, and $000 \mathrm{ppm} \mathrm{CO}$. The instrument is ready for use, and no further preparatory action is required.

The instrument is provided with a time delay OFF switch. To turn the instrument off, it is necessary to maintain pressure on the OFF pad for about $5 \mathrm{~s}$ continuously. This is an added safety feature to ensure that the instrument is not turned off inadvertently.

\subsubsection{Voltage display}

The AIR/BATT switch has a momentary action. Pressing the AIR/BATT position momentarily, then releasing, causes a single tone to sound and then the battery voltage to be displayed. The display will hold for $5 \mathrm{~s}$, then return to the normal display functions. 
MARTIN MARIETTA

ENERGY SYSTEMS, INC.

Oak Ridge National Laboratory
Pollutant Assessments Group

Health and Safety

Procedures Manual
Sect. 16 Rev. 2

Date 6/92

Page 6 of 21

SUBJECT: GASTECH MODEL GX-86 COMBUSTIBLE GAS INDICATOR (CGI)

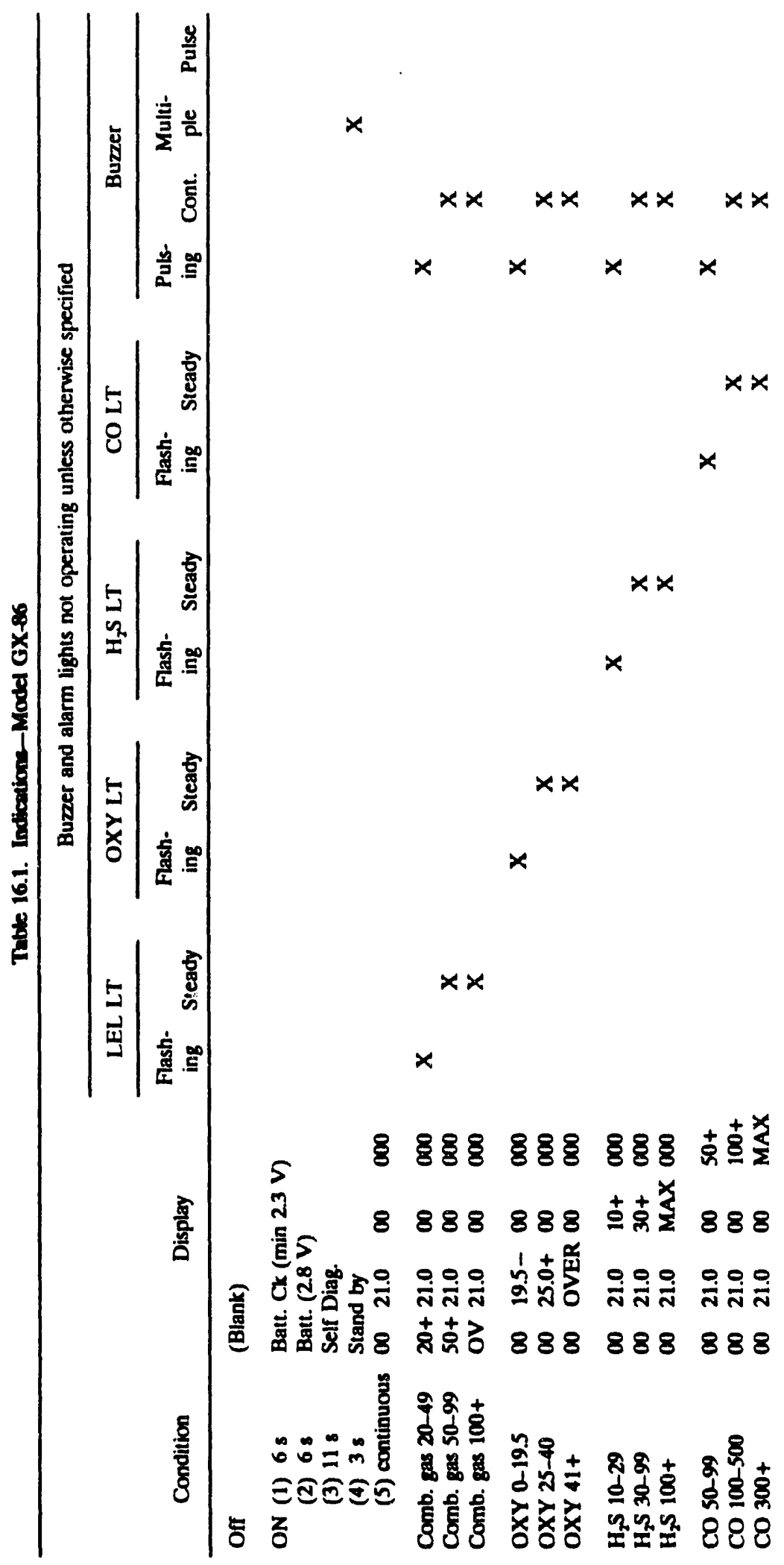


MARTIN MARIETTA

ENERGY SYSTEMS, INC.

Oak Ridge National Laboratory
Pollutant Assessments Group

Health and Safety

Procedures Manual
Sect. 16 Rev. 2

Date $6 / 92$

Page 7 of 21

SUBJECT: GASTECH MODEL GX-86 COMBUSTIBLE GAS INDICATOR (CGI)

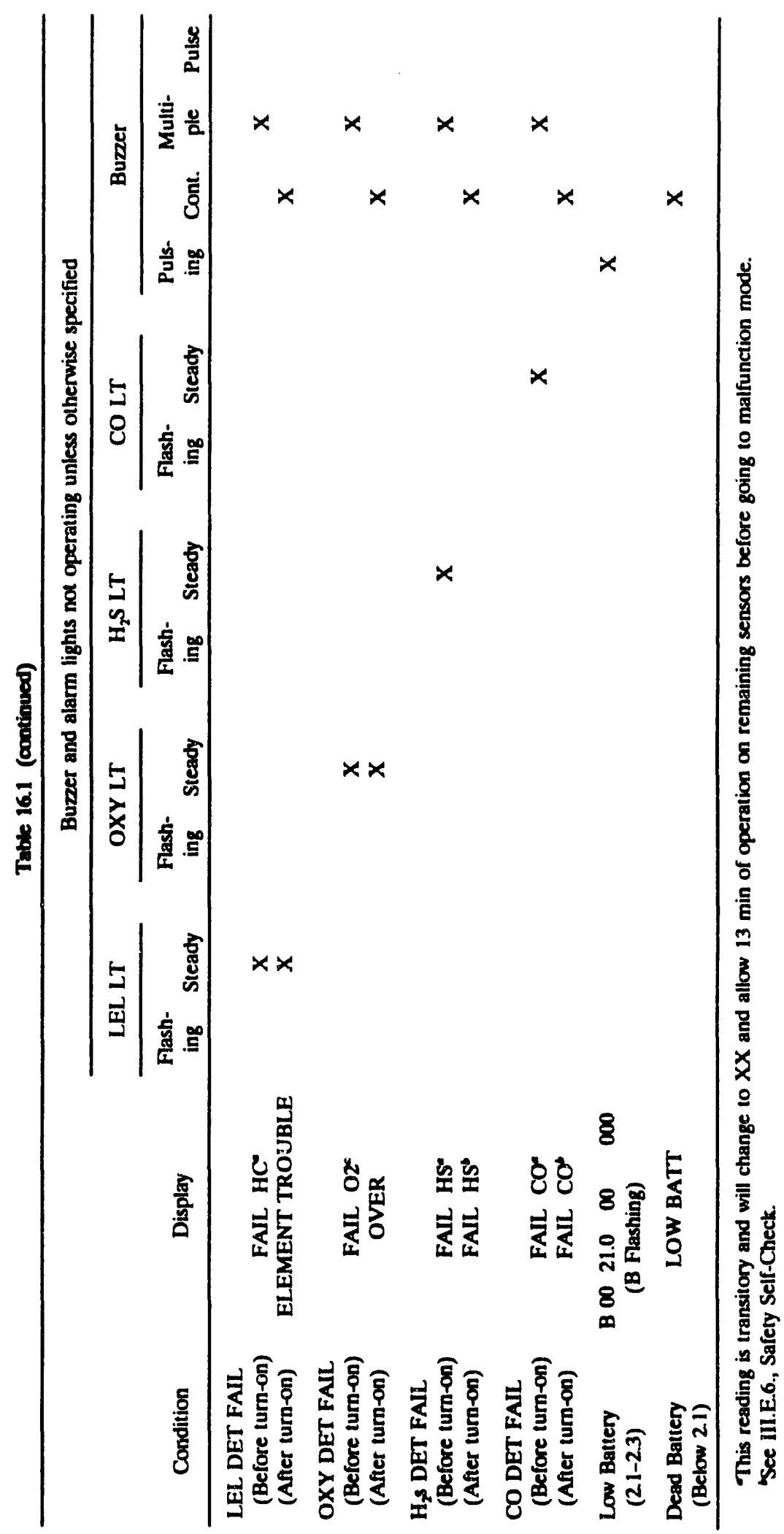


SUBJECT: GASTECH MODEL GX-86 COMBUSTIBLE GAS INDICATOR (CGI)

\subsubsection{Automatic zero adjustment}

The AIR/BATT switch has a second function of initiating automatic zero adjustment when pressed in conjunction with the PEAK switch. To initiate the AUTO ZERO/SPAN mode, press the AIR/BATT switch for $3 \mathrm{~s}$. Then, while still holding the AIR/BATT switch, press PEAK switch and the automatic zero and span adjustment will proceed.

\subsubsection{Updated exposure rate}

The DOSE switch has a momentary action. Each time an $\mathrm{H}_{2} \mathrm{~S}$ or $\mathrm{CO}$ exposure occurs, it is added to all previous exposures, and when the DOSE command is given, the program will divide the stored accumulation by the elapsed time. When the DOSE switch is pressed until a tone is heard, it causes the accumulation program to display the elapsed time and the average $\mathrm{H}_{2} \mathrm{~S}$ and $\mathrm{CO}$ ppm since turn-on.

\subsubsection{Highest gas concentration}

The PEAK switch has a momentary type action. Pressing the PEAK position will cause a single tone and the highest gas concentration reading (lowest in the case of oxygen) to be displayed and retained for $5 \mathrm{~s}$. The highest exposure encountered since the instrument was turned on will be recalied and displayed. At this time the letter $P$ at the left of the display will indicate that the instrument is in the HOLD mode.

NOTE: BATT and DOSE accumulation readings cannot be made while the instrument is in the PEAK mode. Allow the PEAK function to finish before taking either of these readings.

The PEAK switch has the second function of initiating the AUTO ZERO/SPAN adjustment in conjunction with the AIR/BATT switch. See Sect. 16.4.6.3.

\subsubsection{Alarm lights}

Alarm lights COMB, OXY, $\mathrm{CO}$, and $\mathrm{H}_{2} \mathrm{~S}$ are red LEDs and blink with the alarm tone when their respective preset alarm points are reached. They will remain in this condition until the alarm state passes. 
MARTIN MARIETTA

ENERGY SYSTEMS, INC.

Oak Ridge National Laboratory
Pollutant Assessments Groü

Health and Safery

Procedures Manual
Sect. 16 Rev. 2

Date 6/92

Page 9 of 21

SUBJECT: GASTECH MODEL GX-86 COMBUSTIBLE GAS INDICATOR (CGI)

\subsection{BUZZER/EARPHONE}

A solid-state electronic buzzer is mounted at the front of the instrument, behind perforations that permit sound transmission. The buzzer gives a pulsed tone on detection of gas and a continuous $t \mathrm{t}$.e in case of malfunction, higher level of gas, or low battery voltage. A socket located in the lower left rear corner is provided for an extension buzzer. For example, a remote buzzer may be used to warn personnel in a manhole and personnel on top simultaneously to prepare for possible evacuation. Also, an added buzzer located on the lapel may be used in areas of high noise level.

As an alternative to the lapel buzzer, an earphone may be used. An earphone socket is provided at the lower right rear corner; an attenuated buzzer output prevents any hearing damage. Any transistor radio monaural earphone with a $2.5-\mathrm{mm}$ phonc plug may be used.

See Parts List, Table 16.2, for a listing of available parts.

\subsection{BATTERIES}

The Model GX-86 is powered by two C-size alkaline dry cells, which will run the instrument for approximately $10 \mathrm{~h}$. Rechargeable nickel-cadmium C-size cells may be used but must be removed to be recharged. They will run the instrument for approximately $7 \mathrm{~h}$. Access to the batteries is through a removable sliding access door on the front of the instrument.

As an available option, a built-in charger adapter can be provided, which allows nickel-cadmium batteries to be charged in place. This conversion must be carried out at the factory.

\subsection{CIRCUIT BOARDS}

All circuit components are arranged on two printed circuit boards. The main analyzer board lies along the back of the instrument and contains the connectors for the detachable diffusion head, control circuits, and adjustment potentiometers, which are accessible when the battery cover is removed. 
MARTIN MARIETTA

ENERGY SYSTEMS, INC.

Oak Ridge National Laboratory
Pollutant Assessments Group

Health and Safety

Procedures Manual
Sect. 16 Rev. 2

Date 6/92

Page 10 of 21

SUBJECT: GASTECH MODEL GX-86 COMBUSTIBLE GAS INDICATOR (CGI)

Table 16.2 Parts list

\begin{tabular}{ll}
\hline Stock No. & \\
\hline $33-7104$ & Flanged synthetic rubber adapter, CO filter \\
$13-0190$ & Carrying strap, replacement \\
$20-X X X X$ & Vinyl case \\
$10-0606$ & Carrying case \\
$21-X X X X$ & Battery cover \\
$21-X X X X$ & Detector cover \\
$33-7101$ & CO filter \\
$47-1631$ & Detector extension cable, 5 m \\
$47-1635$ & Detector extension cable, 10 m \\
$49-1211$ & Battery, size C, nickel-cadmium (2 required) \\
$49-1503$ & Battery, size C, nickel-cadmium (optional, 2 required) \\
$49-2006$ & Charger, external, for Ni-Cad batteries, 115 V ac \\
$52-2031$ & Buzzer, repeater, lapel type \\
$52-2052$ & Alarm repeater, ear-muff type \\
$52-7515$ & Alarm repeater, single ear \\
$61-0220 \mathrm{E}$ & Combustibles detector, exchange \\
$61-0220$ & Combustibles detector, replacement \\
$61-\mathrm{XXXX}$ & Detector block, plug-in \\
$65-1051$ & Oxygen cell, replacement \\
$65-1051 \mathrm{E}$ & Oxygen cell, exchange \\
$65-2003$ & Carbon monoxide cell, replacement \\
$65-2003 \mathrm{E}$ & Carbon monoxide cell, exchange \\
$65-2033$ & Hydrogen sulfide cell, replacement \\
$65-2033 \mathrm{E}$ & Hydrogen sulfide cell, exchange \\
$81-0012$ & Calibration cylinder, 2.5\% methane \\
$81-0069$ & Calibration cylinder, 200 ppm CO in $\mathrm{N}_{2}$ \\
$81-0151$ & Calibration cylinder, 25 ppm $\mathrm{H}_{2} \mathrm{~S}$ \\
$81-0312 \mathrm{C}$ & Calibration kit, H ${ }^{2} \mathrm{~S}$ plus $2.5 \%$ methane plus 200 ppm CO \\
$81-1112$ & Calibration cup \\
$81-1152$ & Sample-drawing adapter \\
\hline
\end{tabular}


MARTIN MARIETTA

ENERGY SYSTEMS, INC.

Oak Ridge National Laboratory
Pollutant Assessments Group

Health and Safety

Procedures Manual
Sect. 16 Rev. 2

Date 6/92

Page 11 of 21

SUBJECT: GASTECH MODEL GX-86 COMBUSTIBLE GAS INDICATOR (CGI)

The display board is canted parallel to the face and contains the light sensor, display, control switches, alarm lights, and display control circuits.

All board interconnections are by plug-in connectors for convenient maintenance.

\subsection{PREPARATION}

Very little preparation is required for this instrument. It should be kept and used in its vinyl carrying case. It may be used with the detector plugged directly into the bottom socket or used remotely with the diffusion head extender cable. The cable is attached as follows:

WARNING: Each time an extender cable is attached or removed, readjustment steps (Sects. 16.9.1 and 16.9.2) must be performed before the instrument is put into use. Failure to do so will result in erroneous readings and possible hazard to personnel.

1. Temporarily release catches of outer vinyl case to gain access to detector cover.

2. Slide the slotted cover downward and away from the instrument, releasing it by pressing on the spring retainer.

3. Move aside the two spring clips that hold the detector assembly in place.

4. Attach the mating end of the cable to the instrument, and lock the spring clips in place.

5. Attach the detector assembly to the opposite end of the cable, lock the spring clips in place, and slide the slotted cover over the detector assembly, being sure it snaps into place.

6. To minimize shock damage, slip the rubber protective boot over the detector assembly.

\subsection{OPERATION}

This instrument is fully automatic and requires only that it be turned on and that normal indications are confirmed. 
MARTIN MARIETTA

ENERGY SYSTEMS, INC.

Oak Ridge National Laboratory
Pollutant Assessments Group

Health and Safety

Procedures Manual
Sect. 16 Rev. 2

Date $6 / 92$

Page 12 of 21

SUBJECT: GASTECH MODEL GX-86 COMBUSTIBLE GAS INDICATOR (CGI)

\subsubsection{Initial Activation Procedures}

Press the ON switch. A single tone will sound and the display will indicate a series of statements in the following sequence:

1. BATT. CK (MIN 2.3V), the minimum battery voltage that will operate the instrument.

2. BATT. (X.X V), actual battery voltage (e.g., 2.9 V.)

3. SELF DIAGNOSIS, microprocessor-controlled readiness of instrument, indicating that preparation for adjustment is occurring.

4. STAND BY, a built-in pause to give microprocessor time to reset circuits.

5. $\quad 00,20.9,00,000$; a double tone will sound indicating the sequence is complete.

(These readings may deviate slightly from the ideal values shown).

\subsubsection{Data recording}

Record data in the comment section on the PID air quality monitoring form (Fig. 14.1). Turn over all field data forms to the SSHO and copies to the SPM.

\subsubsection{Span Adjustment}

If above readings deviate substantially from ideal, the zero and oxygen span settings may need adjustment. To adjust:

1. Take instrument to a known fresh air location.

2. Press AIR/BATT switch for $3 \mathrm{~s}$.

3. Then, also press PEAK switch. Instrument will self-adjust to the ideal readings shown above and retain these settings until again readjusted, even after the instrument has been turned on or off repeatedly.

\subsubsection{Quick Field Check}

The instrument is now ready for use. To reassure that operation is normal, breathe out over detector end of instrument. Oxygen reading should drop down to perhaps 18 and audible and visual alarms should activate.

A quick check of combustibles response can also be made with a controlled source of vapor, such as from a bottle of isopropyl (rubbing) alcohol. Although a butane cigarette lighter is an easy way to make a response check, this practice of exposing the sensor to 
MARTIN MARIETTA

ENERGY SYSTEMS, INC.

Oak Ridge National Laboratory
Pollutant Assessments Group

Health and Safety

Procedures Manual
Sect. 16 Rev. 2

Date $6 / 92$

Page 13 of 21

SUBJECT: GASTECH MODEL GX-86 COMBUSTIBLE GAS INDICATOR (CGI)

uncontrolled high concentrations has been found to lead to low response and a short life and should be avoided.

\subsection{DETECTION}

The display will continuously indicate the gas, oxygen, $\mathrm{H}_{2} \mathrm{~S}$, and $\mathrm{CO}$ concentrations.

If the gas reading (LEL) rises above the first alarm setting, normally $20 \%$, the buzzer will sound in a series of pulses with the COMB alarm light. If the reading continues to rise and goes above $50 \%$, the alarm tone and light will become steady. Similarly, if the oxygen reading falls below its normal $19.5 \%$, the buzzer will sound and the OXY alarm light will come on in a series of alternating pulses. In addition, when the oxygen content rises above $25 \%$, the buzzer will sound a continuous warning. If the $\mathrm{H}_{2} \mathrm{~S}$ concentration exceeds $10 \mathrm{ppm}$ or if the $\mathrm{CO}$ concentration exceeds $50 \mathrm{ppm}$, the buzzer will sound a series of long pulses synchronistically with the $\mathrm{H}_{2} \mathrm{~S}$ or $\mathrm{CO}$ light. If reading rises to $30 \mathrm{ppm} \mathrm{H}_{2} \mathrm{~S}$ or $100 \mathrm{ppm} \mathrm{CO}$, both light and tone will become steady (Table 16.1).

\subsection{BATTERY STATUS}

Actual battery voltage displayed automatically at turn-on may be compared with minimum voltage to estimate probable battery life remaining. A new set of batteries reads close to $3.0 \mathrm{~V}$, and the minimum operating voltage is $2.2 \mathrm{~V}$.

When voltage reaches 2.2 , the letter " $\mathrm{B}$ " flashes intermittently at the left end of the display, accompanied by a pulsing audible tone. When voltage reads 2.1 , the system goes to low battery condition, a buzzer sounds continuously, and the display shows LOW BATT.

When the AIR/BATT button is pressed momentarily and released, a single tone is heard and the display will indicate the battery voltage for $5 \mathrm{~s}$. This test may be made at any time after instrument has been put into operation.

If the battery voltage is below $2.2 \mathrm{~V}$ prior to turn on, the instrument will not start.

\subsection{SAFETY SEIF-CHECK}

It is unlikely that during proper operation any malfunctions would occur. However, a continuous "trouble" tone is provided to warn the user under the following conditions: 
MARTIN MARIETTA

ENERGY SYSTEMS, INC.

Oak Ridge National Laboratory
Pollutant Assessments Group

Health and Safety

Procedures Manual
Sect. 16 Rev. 2

Date 6/92

Page 14 of 21

\section{SUBJECT: GASTECH MODEL GX-86 COMBUSTIBLE GAS INDICATOR (CGI)}

1. If any of the detector circuits should fail "open" prior to turn-on. The display will indicate $\mathrm{FAIL}$ ( $\mathrm{HC}, \mathrm{O} 2, \mathrm{HS}$ or $\mathrm{CO}$ ).

2. Should either or both of the combustible's elements open up after turn-on, display will indicate ELEMENT TROUBLE.

3. Should the oxygen detector circuit fail open after turn-on. Display will indicate 00 OVER 00000.

4. When the useful life of the batteries has been exhausted, LOW BATT will be displayed. Replace with two C-size disposable alkaline dry cells, or recharge if rechargeable cells have been used.

5. Should the $\mathrm{H}_{2} \mathrm{~S}$ or $\mathrm{CO}$ cell fail or be removed after first turning it on, this will not be noticed immediately. However, every $13 \mathrm{~min}$ the instrument goes through a "SELF-DIAGNOSIS" period, and during this time a malfunctioning electrochemical cell will be detected and will be indicated by a FAIL $\mathrm{H}_{2} \mathrm{~S}$ or FAIL CO malfunction indication.

\subsection{EMERGENCY OPERATION}

The Model GX-86 is capable of temporary operation on the remaining detectors, even if one or more sensors should fail. If any one or more is disconnected at the time of turn-on, then the instrument will give seven audible pulses, readjust for the remaining sensors, and give an XX display at the position of the defective sensor or sensors. Normal operation can be continued for the remaining active sections for $13 \mathrm{~min}$, after which the instrument goes through a SELF DIAGNOSIS step and then goes into the malfunction condition. It must be turned off, and then turned on to restart for another 13-min period.

If a malfunction occurs during operation, the defective channel goes into malfunction alarm and the instrument must be turned off, then turned back on. Then operation can be resumed for another $13 \mathrm{~min}$, without benefit of the defective sensor, and $\mathrm{XX}$ will be displayed.

\subsection{PEAK HOLD}

The peak hold feature is put into effect by pressing the PEAK switch pad. Hold it down for at least a second, and listen for a single audible pulse, which confirms that the microprocessor has accepted the instruction. A letter " $P$ " will appear at the far left of the display.

While in this mode, for $5 \mathrm{~s}$ the display will show the reading that represents the maximum deviation from normal that has been experienced during the entire operating period since the instrument was first turned on; that is, the highest reading for the 
MARTIN MARIETTA

ENERGY SYSTEMS, INC.

Oak Ridge National Laboratory
Pollutant Assessments Group

Health and Safety

Procedures Manual
Sect. 16 Rev. 2

Date $6 / 92$

Page 15 of 21

SUBJECT: GASTECH MODEL GX-86 COMBUSTIBLE GAS INDICATOR (CGI)

combustibles, $\mathrm{H}_{2} \mathrm{~S}$ and $\mathrm{CO}$ ranges, and the lowest for oxygen. This extreme reading will be "remembered" by the instrument until a higher reading occurs or until the instrument is turned OFF. This relieves the operator of the need to watch the display constantly for a maximum reading.

\subsection{PSI CALIBRATION}

Because this instrument is microprocessor controlled, many of the adjustments, such as the alarm thresholds, are automatic or are factory set. There are only four internal adjustments to be made.

The four internal adjustments are the COMB SPAN, the O ZERO, the $\mathrm{H}_{2} \mathrm{~S}$ SPAN, and the CO SPAN. A fifth adjustment, COMB $1.5 \mathrm{~V}$, is factory set and need not be changed. These are on the main analyzer circuit board next to the battery holder and are available when the battery cover is removed. Carry out the following steps to make these adjustments:

NOTE:

1. Any intermittent audible alarms sounded during this adjustment time may be ignored.

2. The instrument is rather slow in responding to adjustment changes. Make a small adjustment and wait $15 \mathrm{~s}$ for the effect to show. Clockwise rotation tends to increase the reading.

\subsubsection{LEL Span}

1. Turn instrument on and allow it to warm up and stabilize for $5 \mathrm{~min}$.

2. Open battery compartment by sliding cover outward. Locate COMB SPAN potentiometer on circuit board. (Left hand control of the four accessible ones, as viewed from exposed end of battery compartment.)

3. Expose combustibles detector to a known calibrating gas sample. If sample is under pressure (e.g., the GasTech Calibration Kit), the mixture should be allowed to flow directly over the combustibles detector (the one on the far left).

CAUTION: The combustibles measurement is flow-sensitive. Always use a low flow rate, barely audible when escaping from the calibration cylinder. If a flowmeter is available, set to $0.8 \mathrm{SCFH}(0.41 / \mathrm{m})$.

4. Watch combustible display carefully. If reading does not correspond to desired value, adjust it by turning SPAN potentiometer. 
MARTIN MARIETTA

ENERGY SYSTEMS, INC.

Oak Ridge National Laboratory
Pollutant Assessments Group

Health and Safety

Procedures Manual
Sect. 16 Rev. 2

Date 6/92

Page 16 of 21

\section{SUBJECT: GASTECH MODEL GX-86 COMBUSTIBLE GAS INDICATOR (CGI)}

5. Recheck zero, and repeat above steps until correct reading is obtained.

6. If reading cannot be set high enough, replace combustibles detector. (Sect. 16.1.6.6 Detector Removal/Replacement.)

\subsubsection{Oxygen Zero}

1. While battery compartment is still open, identify O ZERO potentiometer (the one next in line to the COMB SPAN).

2. Expose oxygen detector to a known oxygen-free sample such as nitrogen, argon, or helium.

3. Watch display carefully. If reading does not go exactly to zero, adjust it by turning ZERO potentiometer.

4. If zero adjustment cannot be made, have oxygen cell reactivated.

5. If instrument cannot bring reading to $20.9 \% \mathrm{O}_{2}$ during the first cycle after turn-on, replace cell or have it reactivated. (Sect. 16.1.6.6 Detector Removal/Replacement.)

\subsection{3 $\mathrm{H}_{2} \mathrm{~S} /$ CO SPAN}

Adjustments to $\mathrm{H}_{2} \mathrm{~S}$ and $\mathrm{CO}$ circuits are similar and are presented here together.

1. With the case open, identify the $\mathrm{H}_{2} \mathrm{~S}$ or CO SPAN potentiometer (right-hand pair).

2. Expose $\mathrm{H}_{2} \mathrm{~S}$ or $\mathrm{CO}$ detector to a known calibrating gas sample as in Sect. 16.15.2.

3. Watch $\mathrm{H}_{2} \mathrm{~S}$ or $\mathrm{CO}$ display carefully. If reading does not correspond to desired value, adjust it by turning $\mathrm{H}_{2} \mathrm{~S} / \mathrm{CO}$ SPAN potentiometer.

4. If reading cannot be set high enough, replace detector. (Sect. 16.1.6.6 Detector Removal/Replacement.)

\subsection{MANTENANCE}

\subsubsection{Batteries}

1. Check battery voltage periodically by pressing BATT (battery) button. Replace before voltage reaches the minimum allowable voltage, as shown during the initial cycle. (Sect. 16.11).

2. To replace cells, remove battery compartment cover by sliding off to the side. Cells are held by springs and may be forced out with the fingers. Verify that the battery compartment is clean. Snap in new alkaline C-size cells or recharged Ni-Cad cells, noting polarity, and replace compartment cover. A complete parts list is detailed in Table 16.2 . 
MARTIN MARIETTA

ENERGY SYSTEMS, INC.

Oak Ridge National Laboratory
Pollutant Assessments Group

Health and Safety

Procedures Manual
Sect. 16 Rev. 2

Date 6/92

Page 17 of 21

\section{SUBJECT: GASTECH MODEL GX-86 COMBUSTIBLE GAS INDICATOR (CGI)}

NOTE: Ordinary carbon-zinc cells can be used but will give very short life, approximately 3 to $4 \mathrm{~h}$. Their use is not recommended because, if left in the instrument while in a discharged state, leakage can cause severe damage.

3. Self-discharge. The batteries are constantly supplying a small current to maintain the toxic gas cells in a state of readiness, even when the instrument is turned off; thus, a certain rate of self-discharge is normal. In the usual application of the GX-86, with operation at least once every 2 weeks, this self-discharge will not be noticed. However, if the instrument is left idle for several weeks at a time, it will probably be necessary to replace batteries before use.

\subsubsection{Combustibles Detector}

1. Detector assembly may require replacement if:

a. The instrument cannot be calibrated on a known gas within range of the LEL SPAN potentiometer.

b. LEL display will not read $0 \%$ when initial cycle is completed.

2. A complete replacement plug-in detector may be ordered from the factory. An exchange allowance is made on returned detectors.

\subsubsection{Oxygen Detector}

1. Oxygen detector assembly may require repair if:

a. Zero reading cannot be obtained on an oxygen-free gas within range of the OXYGEN ZERO potentiometer.

b. Oxygen display will not read $21.0 \%$ when initial cycle is completed.

c. Oxygen reading tends to drift with instrument position.

\subsection{4 $\mathrm{H}_{2} \mathrm{~S}$ or $\mathrm{CO}$ Detector}

1. $\mathrm{H}_{2} \mathrm{~S}$ or $\mathrm{CO}$ detector may require replacement if:

a. Instrument cannot be calibrated on known gas sample, using the respective SPAN potentiometer.

b. Display will not read " 00 " for $\mathrm{H}_{2} \mathrm{~S}$ or " $000^{n}$ for $\mathrm{CO}$ when initial cycle is completed. 
MARTIN MARIETTA

ENERGY SYSTEMS, INC.

Oak Ridge National Laboratory
Pollutant Assessments Group

Health and Safety

Procedures Manual
Sect. 16 Rev. 2

Date 6/92

Page 18 of 21

SUBJECT: GASTECH MODEL GX-86 COMBUSTIBLE GAS INDICATOR (CGI)

NOTE: Do not expect $\mathrm{H}_{2} \mathrm{~S}$ or $\mathrm{CO}$ cell to give correct readings immediately after cell has been plugged into instrument or batteries have been installed. Wait an hour before attempting to use it, and up to $12 \mathrm{~h}$ for final stabilization. The cell requires conditioning by operation at a low voltage (bias voltage), which is supplied by the circuit continuously whether the instrument is on or off. Removal of the cell or disconnecting the battery for a few minutes, as when installing the extender cable or replacing batteries, does not necessitate the restabilization time.

\subsubsection{Detector Repair}

If any of the plug-in detector assemblies requires repair, it should be sent to the factory for rebuilding or reactivation. A replacement sensor can be ordered on an exchange basis.

Cells for $\mathrm{O}_{2}, \mathrm{H}_{2} \mathrm{~S}$, and $\mathrm{CO}$ are electrochemical devices that will gradually deteriorate, regardless of usage of the cell. They require periodic factory reactivation, consisting of replacement of the electrolyte or total rebuilding, which is done at the factory at a flat rate on an exchange basis.

New or reactivated cells are guaranteed usable for 1 year, or other schedule to be stipulated by GasTech at the time of sale, and any cells returned for reactivation within that time period will be inspected and tested for operability. If found to have failed prematurely, they will be reactivated at a prorated cost. Cells are date-coded.

NOTE: These detectors are not interchangeable. Each detector must be placed in its own socket.

\subsubsection{Recording CGI office calibration}

Necessary calibration data to be recorded in the office and/or field logbook include:

1. Date and time of entry.

2. Site identification.

3. Instrument, model number, and serial number.

4. Calibration gas used.

5. Instrument calibration technician. 
SUBJECT: GASTECH MODEL GX-86 COMBUSTIBLE GAS INDICATOR (CGI)

\subsubsection{Detector Removal/Replacement}

All detectors are of the bayonet-base type and are easily removed and replaced. To change detector:

1. Slide the slotted diffusion head cover down and away from the instrument to expose detector.

2. Release spring clips and unplug detector head assembly.

3. To remove individual detectors, press inward on detector and rotate counterclockwise to release bayonet pins. Pull detector from socket.

4. Install in reverse order, being sure the detector is locked in place.

WARNING: After any detector or cell is replaced, the instrument must be run through its AUTO ZERO/SPAN cycle in a clean-air gas-free atmosphere. (See Sects. 16.15.2 and 15.15.3.) Remember that a $\mathrm{CO}$ or $\mathrm{H}_{2} \mathrm{~S}$ detector requires a stabilization period to operate accurately.

\subsubsection{CO Filter}

The $\mathrm{CO}$ filter is a disk containing activated carbon, which will remove $\mathrm{H}_{2} \mathrm{~S}$ and most hydrocarbons, thus eliminating many possible sources of interference with the $\mathrm{CO}$ measurement. The CO filter (33-7101) should be used whenever it is desired to detect CO only.

To use, the filter must be placed over the end of $\mathrm{CO}$ cell and maintained in position by the flanged synthetic rubber sleeve, which seals it onto the detector. Replace the filter when the $\mathrm{CO}$ readings become suspect.

\subsection{OPTIONAL ACCESSORIES}

\subsubsection{Extender Cable}

Extender cables of various lengths are available that permit dropping or placing the detector assembly at a point remote from the instrument, for example, to check the atmosphere within a tank or a manhole prior to entry. The instrument end of the cable clamps to the lower end of the GX-86, in place of the detector block, because it has contact pins that match the pin arrangement of the block. A socket at the far end of the cable is a socket mates with the pins of the detector. 
MARTIN MARIETTA ENERGY SYSTEMS, INC.

Oak Ridge National Laboratory
Pollutant Assessments Group

Health and Safety

Procedures Manual
Sect. 16 Rev. 2

Date 6/92

Page 20 of 21

SUBJECT: GASTECH MODEL GX-86 COMBUSTIBLE GAS INDICATOR (CGI)

Cable lengths of 5 and $10 \mathrm{~m}$ are available as standard; other special lengths up to $50 \mathrm{ft}$ can be supplied. Remember that the instrument must be readjusted before use when any cable is added or removed. (See Sect. 16.8 and 16.9.)

\subsubsection{Sample Drawing Accessory}

The Model GX-86 is designed primarily as a diffusion-sampling instrument, and operation in the diffusion mode, with the detector head immersed in the space to be tested, is recommended whenever practical. However, in some applications, such as testing through small openings in tanks or manhole covers, the sample-drawing mode is more advantageous.

For this application, a sample-drawing accessory is available. It consists of a hose and probe for insertion into the space to be tested, an aspirator bulb to provide suction for drawing the sample, and a plastic block with O-ring seal to slip over the detectors. To install, first remove slotted detector cover and then press block over the detectors, noting that the cavity with the O-ring seal goes over the $\mathrm{H}_{2} \mathrm{~S}$ detector. Be sure the charcoal filter disc is in the bottom of the $\mathrm{CO}$ detector cavity.

To take a sample, insert probe into space to be tested. Squeeze bulb at least ten times. If any reading is noted, continue sampling until maximum reading is obtained.

\subsubsection{Confined Space Entry Kit}

A complete kit including the Model GX-86, a 5-m extender cable and a sample-drawing accessory, is available in a rugged, waterproof, padded carrying case. Components may be purchased as individual items or as a complete kit.

\subsubsection{Lapel Buzzer}

A repeater buzzer is offered, that provides a louder sound and may be placed closer to the ear for use in noisy environments. It plugs into the socket at the lower edge of GX-86 and has a spring clip for convenient attachment to shirt pocket or lapel.

\subsubsection{Earphones}

A small single earphone is available that plugs into the earphone jack on the bottom of instrument (opposite the "Buzzer" jack). This can be worn in one ear and produces an audible tone similar to the internal buzzer. This will be effective in moderately noisy areas. 
MARTIN MARIETTA

ENERGY SYSTEMS, INC.

Oak Ridge National Laboratory
Pollutant Assessments Group

Health and Safety

Procedures Manual
Sect. 16 Rev. 2

Date $6 / 92$

Page 21 of 21

SUBJECT: GASTECH MODEL GX-86 COMBUSTIBLE GAS INDICATOR (CGI)

A two-ear repeater is available in conjunction with an earmuff-type hearing protector. This serves the function of ear protection and ensures that alarms will be heard even in high-noise areas.

\subsubsection{Nickel-Cadmium Batteries}

For frequent use, rechargeable batteries offer economy over disposable cells and fit into the battery holder in the same way that the disposable ones do. A plug-in charger capable of overnight recharging of two size $\mathrm{D}$ nickel-cadmium cells is offered as an accessory. It operates from any $115 \mathrm{~V}$ ac receptacle.

To order, specify nickel-cadmium batteries and charger separately. (See Table 16.2.)

\subsubsection{Calibration Kit}

The calibration kit contains three cylinders including one for $\mathrm{H}_{2} \mathrm{~S}$. The $\mathrm{H}_{2} \mathrm{~S}$ cylinder is a special type designed to maintain the marked concentration of $\mathrm{H}_{2} \mathrm{~S}$ for at least 6 months. It has its own regulator, which releases. The other cylinders are a standard steel disposable type with a dispensing valve. One cylinder contains $2.5 \%$ methane (about 55\% LEL) for calibrating the combustibles sensor.

The other cylinder contains $200 \mathrm{ppm} C O$ in nitrogen and can be used to calibrate the CO section or check oxygen zero.

All cylinders and valves are packed in a padded carrying case. Individual cylinders can be replaced. (See Table 16.2.)

\subsection{REFERENCES}

Code of Federal Regulations-29, Pt. 1900-1910, 7/87.

Code of Federal Regulations-30, Pt. 1-199, 1986.

Code of Federal Regulations-40, Pt. 150-189, 7/86.

EPA. 1981. Health and safety requirements for employees engaged in field activities. Environmental Protection Agency Order 1440.1. U.S. Environmental Protection Agency, July 12, 1981.

NIOSH. 1985. Occupational safety and health guidance manual for hazardous waste site activities. National Institute for Occupational Safety and Health, Occupational Safety and Health Administration, U.S. Coast Guard, and Environmental Protection Agency, DHHS (NIOSH) Publication 85-115, October 1985. 
MARTIN MARIETTA

ENERGY SYSTEMS, INC.

Oak Ridge National Laboratory
Pollutant Assessments Group

Health and Safety

Procedures Manual
Sect. 17 Rev. 2

Date 6/92

Page 1 of 11

SUBJECT: SENSIDYNE GAS DETECTOR SYSTEM

\section{SENSIDYNE GAS DETECTOR SYSTEM}

\subsection{PURPOSE}

Use of colorimetric detector tubes for simple and rapid measurement of very minute gas or vapor concentrations of potential contaminants in drums, tanks, and other enclosed spaces in the work place.

Colorimetric detector tubes may provide a detailed method for the measurement of hazardous gases and vapors. Some advantages over the PID and CGI are:

1. Better capability of measuring concentrations in the range of threshold limit values.

2. Easy use and availability for taking quick samples in the work environment.

3. Results produced for evaluation and analysis within a few minutes, making it unnecessary to take samples back to the laboratory.

4. Reasonable accuracy and reproducibility.

\subsection{APPLICABUITY}

Each detector tube contains a precise amount of detecting reagents in a constant inner diameter glass tube and is hermetically sealed at both ends. Some detector tubes have short shelf lives; these should be inspected periodically and outdated tubes replaced.

Before proceeding, don safety glasses and/or a face shield. To operate the detector, break off the tips of a fresh tube, connect the tube to the Gastec sampling pump, and pull the handle to take the required sample volume of air (sample gas). The chemical reagent in the detector tube will then react with the sample gas immediately, and a color stain will develop starting at the inlet of the detector tube. The gas concentration is measured at the interface of stained-to-unstained reagent when staining stops.

Gastec detector tubes contain colorimetric reagents adsorbed on fine-grain silica gel, activated alumina, or other absorbing media. The reagents are sensitive to particular gases or vapors and react quantitatively to provide a length-of-stain indication. 
MARTIN MARIETTA

ENERGY SYSTEMS, INC.

Oak Ridge National Laboratory
Pollutant Assessments Group

Health and Safety

Procedures Manual
Sect. 17 Rev. 2

Date $6 / 92$

Page 2 of 11

SUBJECT: SENSIDYNE GAS DETECTOR SYSTEM

\subsection{Characteristics of Gastec Gas Detector System-Detector Tube}

1. A direct-reading calibration scale is printed on each tube.

2. Every tube and tube box displays the quality control number and chemical symbol. The expiration date is stamped on each box.

3. Controlled small internal diameter of tubes provide longer stain length with one pump stroke $(100 \mathrm{~mL})$, resulting in more-accurate readings and shorter sampling times.

4. Sensitive reagents with high reaction rates provide a line of demarcation of color stain.

\subsection{Specifications-Samplin/s Pump}

1. Weight (approximately $10 \mathrm{oz}$ ).

2. Vacuum pull (8.1 in. of $\mathrm{Hg})$.

3. Design does not require flow-rate orifices.

4. Handle locks at precise intake volume of 50 or $100 \mathrm{cc}$.

5. Friction-proof lubricant seal packing provides complete leakproof sampling at all times.

\subsection{ACCURACY OF GASTEC DETECTOR TUBE-CALIBRATION VARIANTS}

It is possible to measure the concentration below the lowest calibration scale by repeating pump strokes. The measuring range of Gastec detector tubes is expanded by varying the number of pump strokes. It is also possible to measure the concentration above the highest calibration scale by using a half-pump stroke.

1. Visually check rubber inlet flange for cracks or tears. Replace if damaged. Tighten inlet clamping nut.

2. Valve leak check

a. Insert a fresh, sealed, unbroken detector tube into pump. Misalign red dots on pump and handle. Pull several fairly rapid continuous full pump strokes.

b. Pull handle out $6 \mathrm{~mm}(1 / 4 \mathrm{in}$.) and hold in this position for 1 or $2 \mathrm{~s}$.

c. Release handle.

d. If handle returns to within $1.5 \mathrm{~mm}$ (1/16 in.) or less of fully closed position, continue to step 3.

e. If handle does not return to within $1.5 \mathrm{~mm}(1 / 16 \mathrm{in}$.) of fully closed position (or less), perform the following valve lubrication instruction outlined in step 4. 
MARTIN MARIETTA

ENERGY SYSTEMS, INC.

Oak Ridge National Laboratory
Pollutant Assessments Group

Health and Safety

Procedures Manuai
Sect. 17 Rev. 2

Date 6/92

Page 3 of 11

\section{SUBJECT: SENSIDYNE GAS DETECTOR SYSTEM}

3. Field volume check

a. Insert a fresh, sealed detector tube into pump.

b. Align guide marks on pump body and handle.

c. Pull handle firmly and at a moderate speed until handle locks into position. Wait $1 \mathrm{~min}$.

d. Unlock handle by turning it, and guide it back.

NOTE: TO PROTECT PUMP STOPPER from breakage, do not release the handle and allow it to spring back when conducting a leak test. Hold your hand on the handle and guide it back.

e. Pump handle should return to within $6 \mathrm{~mm}(1 / 4 \mathrm{in}$.) or less of the fully closed position.

f. If pump handle does not close to within $6 \mathrm{~mm}$ (1/4 in.) or less, follow lubrication instructions and retest.

4. Lubrication instructions (perform laboratory volume check (step 5) after each lubrication)

a. Valve lubrication

(1) Unscrew backplate and withdraw piston from pump cylinder.

(2) Remove check valve from piston.

(3) Clean valve and piston with lint-free cloth. Proper valve cleaning is as follows:

Place cloth flat on desk.

Wipe rubber valve flap in a flat position across cloth.

Do not bend the rubber flap valve.

(4) Apply a small amount of grease evenly around the valve opening to form a thin film. A thin film is nearly invisible.

(5) Replace valve assembly loosely in the same manner as removed.

(6) Before tightening the screw, align valve so that valve hole is in center of valve flap.

(7) Then push the rectangular valve retainer all the way toward loose end of valve flap.

(8) Now tighten screw. If a torque driver is available, tighten to $0.8 \mathrm{~kg}-\mathrm{cm}$. Otherwise, be careful not to overtighten screw. When tightened, screw must not deform rectangular valve retainer.

b. Piston gasket lubrication

(1) Wipe off piston and cylinder with a clean lint-free cloth.

(2) Remove piston gasket with a small bladed screwdriver. Take care not to cut gasket.

(3) Clean slot in piston with lint-free cloth. Wipe off rubber gasket.

(4) Wipe an ample supply of grease into gasket slot on piston and inside gasket. 


\section{SUBJECT: SENSIDYNE GAS DETECTOR SYSTEM}

(5) Replace gasket, making sure that open side of gasket is toward pump handle.

(6) With the excess grease from piston slot, wipe around outside of gasket and piston.

(7) Wipe an ample amount of grease into cylinder at the area of piston entrance.

(8) Insert piston slowly into the cylinder. Work the piston back and forth slowly in the cylinder severai times.

(9) Now screw backplate firmly onto cylinder.

(10) Repeat leak tests.

(11) If leak remains, replace piston gasket.

(12) Only if a leak persists, go to procedure b.

b. Pump head lubrication

(1) This is only necessary where all previous procedures have failed to correct a leak.

(2) Visually check pump head " $O$ " ring for cracks.

(3) Replace "O" ring if cracked.

(4) Place a light coat of grease on pump cylinder head screw threads and the "O" ring.

(5) Insert new " $O$ " ring.

(6) Screw pump head firmly onto " $\mathrm{O}^{n}$ ring and make sure " $\mathrm{O}$ " ring is seated uniformly. Overtightening pump head may push " $\mathrm{O}^{n}$ ring out of place. Do not overtighten.

(7) Wipe off excess grease.

5. Laboratory volume check (To be performed at least once after each lubrication) The Gastec pump should be checked monthly to ensure that $100 \pm 5 \mathrm{~mL}$ are being sampled.

a. Arrange a graduated 100 -mL soap-film flow meter in a volume test mode.

b. Insert a fresh Gastec tube into the pump. The tube must be broken at both ends (ready for use).

c. Attach the Gastec tube to top of soap-film flow meter with rubber hose. Make sure there are no leaks.

d. Pull pump handle out full to lock at one stroke in normal sampling manner.

e. Wait until the bubble stops moving, and read the volume evacuated.

f. If the volume excavated is other than $100 \pm 5 \mathrm{~mL}$, proceed to lubrication instruction and retest. 
MARTIN MARIETTA

ENERGY SYSTEMS, INC.

Oak Ridge National Laboratory
Pollutant Assessments Group

Health and Safety

Procedures Manual
Sect. 17 Rev. 2

Date 6/92

Page 5 of 11

SUBJECT: SENSIDYNE GAS DETECTOR SYSTEM

\subsection{NORMAL OPERATION}

Read the instruction insert in colorimetric tube storage box for specific operating procedures for the tube you are using.

\subsubsection{Sampling and Measurement Procedure}

1. Break off the tips of a fresh detector tube by bending each tube end in the tube tip breaker of the pump.

2. Insert tube securely into pump inlet, with arrow on tube pointing toward pump.

3. For twin tubes, connect marked ends with rubber tubing after breaking each end. Insert analyzer tube into pump with arrows on tubes pointing toward pump.

4. Make certain pump handle is all the way in. Align guide marks on pump body and handle.

5. Pull handle out to desired stroke volume. Handle can be locked on either $1 / 2$ pump stroke $(50 \mathrm{~mL})$ or 1 pump stroke $(100 \mathrm{~mL})$. Carefully adhere to the time limit between strokes specified on the instruction insert in the tube storage box.

6. Read concentration at the interface of stained-to-unstained reagent when staining stops. Unlock handle by making $1 / 4$ turn, and return it to starting position.

7. In case more pump strokes are indicated in the instruction sheet included in each box of tubes, take an additional air volume sample by repeating pump strokes without removing the tube.

\subsubsection{Correction for Temperature, Humidity, or Pressure}

Calibration of the Gastec detector tubes is based on a tube temperature of $20^{\circ} \mathrm{C}$ $\left(68^{\circ} \mathrm{F}\right)$, approximately $50 \%$ relative humidity, and normal atmospheric pressure.

1. No correction is normally required for tube temperature of $0^{\circ}$ to $40^{\circ} \mathrm{C}\left(32^{\circ}\right.$ to $104^{\circ} \mathrm{F}$ ) and for relative humidity range of 20 to $90 \%$.

2. Where the detecting reagent is abnormally sensitive to temperature or humidity, a correction table or chart is provided in each box of tubes. In this case, the tube reading must be corrected using correction table or chart.

3. Tube reading is proportional to absolute pressure. To correct for pressure, multiply by 
MARTIN MARIETTA

ENERGY SYSTEMS, INC.

Oak Ridge National Laboratory
Pollutant Assessments Group

Health and Safety

Procedures Manual
Sect. 17 Rev. 2

Date 6/92

Page 6 of 11

\section{SUBJECT: SENSIDYNE GAS DETECTOR SYSTEM}

$\frac{760}{\text { atmospheric pressure (mmHg) }}$

If numerous pump strokes are required, use the counter ring of the pump in the following way:

(a) Turn the counter ring manually counterclockwise after each pump stroke.

(b) The operator may thus keep count of the number of pump strokes.

For more details see the instruction sheet included in each box of detector tubes. Detector tubes should be stored in accordance with instructions on each box.

\subsection{DIFFERENT METHODS OF SAMPLING}

\subsubsection{Effect of Sampling Time and Related Data}

Concentration of contaminants and chemical substances in the air is always fluctuating. On the other hand, sampling is usually conducted within certain time and frequency limits. Therefore, a deviation naturally exists between the average environmental concentration and results obtained on the basis of grab samples.

The variation of the measured concentration is largely dependent on the sampling time and position. Large differences occur when the operation is intermittent. If the sampling time is short and the quantity of sample gas or vapor is relatively small, large variations will result between instantaneous concentration and average concentration. Under extremely adverse conditions, there can be as much as a tenfold difference in detector tube readings taken at different times in the same location. Additional detector tube applications are detailed in the Sensidyne, Gastec Precision Gas Detector System Manual.

\subsubsection{Tanks, Manholes, or Confined Spaces}

It is dangerous to enter a confined space directly without a precheck. At a minimum, an oxygen and LFL check shall be done before entry (breaking the plane) into a confined space. Following this determination, detector tubes will be used to ascertain the presence of specific gases. Before entering any such enclosed place, the workman must first check the suspected gas level by using an extension hose in at least three levels, that is, the higher, middle, and lower level of the closed area. Confined space work precautions will 
MARTIN MARIETTA

ENERGY SYSTEMS, INC.

Oak Ridge National Laboratory
Pollutant Assessments Group

Health and Safety

Procedures Manual
Sect. 17 Rev. 2

Date 6/92

Page 7 of 11

\section{SUBJECT: SENSIDYNE GAS DETECTOR SYSTEM}

be thoroughly reviewed before employees are allowed to work in confined spaces (see Sect. 8.6.2.1). The reason for this is as follows:

$$
\text { specific gravity of gas }=\frac{\text { mol wt of gas }}{29(\text { av mol wt of air })}
$$

If the specific gravity of the gas is lighter than air (1.0), the gas will rise to the top of the space. However, if the specific gravity heavier than air (1.0), the gas concentration will accumulate at the lower level.

\subsubsection{Leak-Check from Pipeline or Wellhead}

If an air flow or a breeze is observed prior to taking the measurement, measuring points must be moved away from the direction of the air flow.

CAUTION: If the measurement is conducted at a point some distance from the pipeline or wellhead, the gas emitted will be diluted very rapidly, and the true concentration of the gas cannot accurately be detected. Therefore, measurement must be conducted at a point as close as possible to the suspected leak. It is sometimes necessary to collect the gas sample temporarily in a sampling bag or a bottle. Measurement of the concentration is made by passing a sample through an appropriate Gastec tube.

\subsubsection{Measurement and TLV of Liquid Mixture}

A method for measuring concentration of industrial solvents in air is available using a multistroke gas-sampling pump such as the Gastec Precision Gas Detector System.

\subsubsection{Elements evaporating from solvent}

Industrial solvents are liquids but have an appreciable vapor pressure at room temperature. The composition of the vapor arising from the solvent can be quite different from the composition of the solvent itself. 
MARTIN MARIETTA

ENERGY SYSTEMS, INC.

Oak Ridge National Laboratory
Pollutant Assessments Group

Health and Safety

Procedures Manual
Sect. 17 Rev. 2

Date 6/92

Page 8 of 11

\section{SUBJECT: SENSIDYNE GAS DETECTOR SYSTEM}

Take, as an example, a lacquer thinner mixture of $66 \%$ of toluene, $14 \%$ each of ethyl acetate and butyl acetate, $4 \%$ of butyl alcohol, and $2 \%$ of cellosolve. At the early stage of its evaporation, the lower-boiling point material will vaporize first.

The ratio of vaporized components is greatly dependent on the working environment event if the same solvents are used. Therefore, we must carefully consider the environmental assessment of exposure to complex mixtures. Many lacquer-thinner manufacturers keep the ratio of materials secret. However, OSHA has legislated that each producer must publish the principal components and hazardous properties of all proprietary solvents in MSDSs.

\subsubsection{Selecting measuring apparatus}

One of the best methods used in measuring each component of a solvent mixture is by means of gas chromatography. However, a simpler analysis uses detector tubes and is usually preferred for daily environmental measurement. Use of detector tubes and selection of tubes is greatly dependent on the individual case. It is recommended that chemical and physical properties of the suspected components be evaluated for correct interpretation of the results. Items such as interferences and reaction rates have a major effect on the accuracy and precision of the measurement.

\subsubsection{TLV for mixtures}

When two or more hazardous substances are present and have similar toxic effects, their combined effect, rather than that of either individually, would be given primary consideration. In the absence of information to the contrary, the effects of the different hazards should be considered as additive. That is, if the sum of the following fractions,

$$
\frac{C_{1}}{T_{1}}+\frac{C_{2}}{T_{2}}+\ldots \cdot \frac{C_{n}}{T_{n}}
$$

NOTE: This formula should not be used for mixtures with widely differing effects.

exceeds 1 , then the TLV of the mixture should be considered as being exceeded. $C_{1}$ indicates the observed atmospheric concentration, and $T_{1}$ the corresponding TLV. (See example in the following.) 
MARTIN MARIETTA

ENERGY SYSTEMS, INC.

Oak Ridge National Laboratory
Pollutant Assessments Group

Health and Safety

Procedures Manual
Sect. 17 Rev. 2

Date 6/92

Page 9 of 11

\section{SUBJECT: SENSIDYNE GAS DETECTOR SYSTEM}

It is essential that the atmosphere be analyzed both qualitatively and quantitatively for each component present to evaluate compliance or noncompliance with this calculated TLV.

$$
\frac{C_{1}}{T_{1}}+\frac{C_{2}}{T_{2}}+\ldots \frac{C_{3}}{T_{3}}+\ldots=1
$$

Example: $\quad$ Air contains $5 \mathrm{ppm}$ of carbon tetrachloride (TLV $=10 \mathrm{ppm}$ ), $20 \mathrm{ppm}$ of 1,2-dichloroethane (TLV $=50 \mathrm{ppm}$ ), and $10 \mathrm{ppm}$ of 1,2-dibromoethane $(\mathrm{TLV}=20 \mathrm{ppm})$ mixture

Atmospheric concentration of mixture $=5+20+10=35 \mathrm{ppm}$ if

$$
\frac{5}{10}+\frac{20}{50}+\frac{10}{20}=\frac{25+20+25}{50}=1.4
$$

The TLV is exceeded. Furthermore, the TLV of this mixture may be calculated by reducing the fraction to 1.0 (i.e., TLV of mixture $=35 / 1.4=25 \mathrm{ppm}$ ).

Most hazardous waste sites characteristically emit a number of harmful dusts, fumes, vapors, or gases. It will frequently be feasible only to attempt to evaluate the hazard by measuring of a single substance. In such cases, the TLV used for this substance should be reduced by a suitable factor, the magnitude of which will depend on the number, toxicity, and relative quantity of the other contaminants ordinarily present.

\subsection{COMPRESSED AIR ACCESSORY}

"Airtec" is a convenient method of testing whether compressed air is of suitable quality for breathing. Basically, the equipment consists of a pressure reducer, flow meter, and a series of air sampling tubes. The indicating tubes contain a chemical that changes color when contaminants are present in the sample to the preset contaminant level.

1. Connect the correct adaptor to the side of the reducer, making sure that all " $\mathrm{O}$ " rings are in place. Tighten with the spanner or allen key. Do not overtighten.

2. Connect the reducer to the appropriate compressed air source. 
MARTIN MARIETTA

ENERGY SYSTEMS, INC.

Oak Ridge National Laboratory
Pollutant Assessments Group

Health and Safety

Procedures Manual
Sect. 17 Rev. 2

Date 6/92

Page 10 of 11

\section{SUBJECT: SENSIDYNE GAS DETECTOR SYSTEM}

3. Close the fine-adjustment valve at the bottom of the flow meter. (Turn counterclockwise).

4. Ensure the flow meter is vertical. Select the proper Airtec tube, put on eye protection, hold the tube away from your eyes, and break off tips of the fresh tube.

5. Insert the detector tube into the upper end of the rubber tube holder, and then stretch the holder down over the lower end of the tube.

NOTE: The arrow on the side of the tube must point in the same direction of airflow (i.e., downward).

6. Turn on compressed air source and adjust the flow rate with the fine-adjustment valve in accordance with Table 17.1 .

7. After the required time has elapsed, close the valve and remove the tube from the tube holder. The concentration of contaminant in the compressed air is read directly from the calibration marks on the tube.

NOTE: 1. A different tube is used for each contaminant.

2. Each tube may only be used once.

3. The oxygen content will also be checked with an $\mathrm{O}_{2}$ meter and certified to be 19.5 to $23.5 \%$ by volume.

Table 17.1. Purity of compressed air for breathing (extract from B.S. 4275 Clause 5.6.3.1)

\begin{tabular}{llc}
\hline \multicolumn{1}{c}{ Contaminant } & \multicolumn{1}{c}{ Maximum concentration } & Airtec tube No. \\
\hline Carbon monoxide & $5 \mathrm{ppm}\left(6.5 \mathrm{mg} / \mathrm{m}^{3}\right)$ & $1 \mathrm{~A}$ \\
Carbon dioxide & $500 \mathrm{ppm}\left(900 \mathrm{mg} / \mathrm{m}^{3}\right)$ & $2 \mathrm{~A}$ \\
Oil mist & $0.5 \mathrm{mg} / \mathrm{m}^{3}$ & $109 \mathrm{~A}$ \\
Water vapor & $\begin{array}{l}\text { Dew point not to exceed }-50^{\circ} \mathrm{C} \text { at } \\
\text { atmospheric pressure (equivalent to } \\
\end{array}$ & $6 \mathrm{~A}$ \\
\hline
\end{tabular}


MARTIN MARIETTA

ENERGY SYSTEMS, INC.

Oak Ridge National Laboratory
Pollutant Assessments Group

Health and Safety

Procedures Manual
Sect. 17 Rev. 2

Date 6/92

Page 11 of 11

\section{SUBJECT: SENSIDYNE GAS DETECTOR SYSTEM}

\subsection{REFERENCES}

Code of Federal Regulations-29, Pt. 1900-1910, 1990.

Code of Federal Regulations-30, Pt. 1-199, 1988.

EPA. 1981. Health and safety requirements for employees engaged in field activities. Environmental Protection Agency Order 1440.1. U.S. Environmental Protection Agency, July 12, 1981.

NIOSH. 1985. Occupational safety and health guidance manual for hazardous waste site activities. National Institute for Occupational Safety and Health, Occupational Safety and Health Administration, U.S. Coast Guard, and Environmental Protection Agency, DHHS (NIOSH) Publication 85-115, October 1985.

Sensidyne Corporation. 1986. Sensidyne, Gastec Precision Gas Detector System Manual. Sensidyne Corporation, Largo, Fla. (February). 
SUBJECT: QUEST ELECTRONICS MICRO-14 NOISE DOSIMETER

\section{QUEST ELECTRONICS MICRO-14 NOISE DOSIMETER}

\subsection{PURPOSE}

To describe the equipment and procedures for monitoring potentially damaging noise levels in order to ensure continued hearing proficiency and limit physiological stress of ORNL and subcontracted personnel.

\section{APPLICABILITY}

This instrument is designed and intended for personnel safety in entering or occupying environments that have the potential to cause or contribute to hearing impairment. The instrument is certified to be in compliance with OSHA and MSHA mandates and will be used to comply with other applicable requirements.

\subsection{SPECIFICATIONS}

Standards: ANSI S1.4-1983 type 2

ANSI S1.25-1978

IEC 651 type 2 (sound level reads slow response level once each second) IEC 804 type 2

Detector: True RMS; $63 \mathrm{~dB}$ pulse range and crest factor

Range: 50-146 dB (Percentage dose and average level from threshold to $146 \mathrm{~dB}$.)

Frequency weighting: " $A$ "

Overlimit level: $11.5 \mathrm{~dB}$ (Consult factory for other settings.)

Thresholds: 80 or $90 \mathrm{~dB}$ (Consult factory for other settings.)

Exchange rates: 3 or $5 \mathrm{~dB}$ (Consult factory for other settings.)

Criterion levels: 85 or $90 \mathrm{~dB}$ (Consult factory for other settings.)

Readout: 4-digit liquid-crystal display

Dose: 0.01 to $19999 \%$

Time: hours, minutes, and seconds

Sound level: $0.1 \mathrm{~dB}$

Integrated sound level: $0.01 \mathrm{~dB}$

\section{APPROVED BY:}


MARTIN MARIETTA

ENERGY SYSTEMS, INC.

Oak Ridge National Laboratory
Pollutant Assessments Group

Health and Safety

Procedures Manual
Sect. 18 Rev. 2

Date $6 / 92$

Page 2 of 14

\section{SUBJECT: QUEST ELECTRO IICS MICRO-14 NOISE DOSIMETER}

Microphone: $8 \mathrm{~mm}$ (1/4 in.), omnidirectional ceramic with collar clip and 36-in. cable Battery: Single 9-V alkaline; 80 -h battery life

Battery indicator: Shows at least 8-h battery life is available.

Calibration: External calibrator.

Temperature: -10 to $+50^{\circ} \mathrm{C}$ operating; -40 to $+60^{\circ} \mathrm{C}$ storage (battery removed).

Humidity: 0 to $95 \%$ RH

Magnetic field effects: Negligible below $4000 \mathrm{R} / \mathrm{M}$ (50 oersteds) at 50 to $6 \mathrm{~Hz}$.

Size: $2.5 \times 5.1 \times 1.3$ in. $(64 \times 130 \times 33 \mathrm{~mm})$.

Weight: $11 \mathrm{oz}(315 \mathrm{~g})$ including battery and cover plate.

Construction: The entire microprocessor is fully enclosed in aluminum housing with tamper-, water-, and dust-resistant security cover.

\subsection{INSTRUMENT DESCRIPTION}

The Quest Micro-14 Noise Dosimeter is a portable, automatic microprocessorcontrolled instrument. It simultaneously monitors for sound level, maximum sound level, average integrated sound level, percentage dose, run time, pause time, and overlimit time. As a personal instrument, it may be carried by means of a belt loop, leaving the hands free for normal work. It can also be used as hand-held noise survey instrument and an area monitor. It is fully automatic and self-adjusting. No data will be lost if the dosimeter is turned off; stored data will only be cleared by the reset operation.

\section{DETECTION}

Data compilation. This instrument contains a special microprocessor program that will present at any time any of the noise and time-related exposures accumulated since the time the instrument was last reset. After the ON and RUN switches are pressed, the program will collect and store the noise exposure data. Each time an exposure occurs, it is added to all previous exposures until the instrument is again reset. When individual display command is given, the program will divide the stored accumulation by the elapsed time and the display will show the TWA in decibels, as well as the elapsed time.

If for any reason the noise concentration should exceed the preset over-limit detection (requiring immediate noise-reduction measures) ceiling of $115 \mathrm{~dB}$ for more than $1 \mathrm{~s}$, the duration and noise levels up to $146 \mathrm{~dB}$ will be stored as a TWA exposure in the memory. Noise levels exceeding $146 \mathrm{~dB}$ will only be stored and displayed as $146 \mathrm{~dB}$ for the duration of this occurrence. 
MARTIN MARIETTA

ENERGY SYSTEMS, INC.

Oak Ridge National Laboratory
Pollutant Assessments Group

Health and Safety

Procedures Manual
Sect. 18 Rev. 2

Date 6/92

Page 3 of 14

SUBJECT: QUEST ELECTRONICS MICRO-14 NOISE DOSIMETER

\subsubsection{Microcomputer Modes}

The MICRO-14 is controlled by an MC146805 CMOS Microcomputer. The MC146805, in addition to being a general-purpose microprocessor, has 32 input/output lines, 112 bytes of RAM, 2106 bytes of ROM, a counter, an interrupt, a low-power wait state, and a very-low-power stop state.

\subsubsection{Weighting Characteristics}

The MICRO-14 has an " $A$ " weighting characteristic. The $A$ weighting indicates a response similar to that of the human ear.

\subsubsection{Microphone Characteristics}

The microphone used on the MICRO-14 Dosimeter is a Model 1845 ceramic microphone. An integral amplifier and a controlled acoustical construction provide the transduction sensitivity level, frequency range, and frequency response required by Type 2 instruments. Overall diameter is $8 \mathrm{~mm}$. Typical sensitivity is $70 \mathrm{~dB}$ below $1 \mathrm{~V}$ per microbar measured at $1 \mathrm{kHz}$.

\subsubsection{Internal Electrical Noise}

The internal electrical noise of the MICRO-14 is equivalent to an acoustical level of approximately $40 \mathrm{~dB}$. This is $30 \mathrm{~dB}$ or more below the threshold and $10 \mathrm{~dB}$ below the minimum sound level and has little effect on the readings.

\subsection{CONTROLS AND INDICATORS}

- ON/OFF: The instrument is turned on at the touch of switch pads; however, sustained pressure on the OFF pad for $5 \mathrm{~s}$ is required to turn it off. Adjustments to zero are automatic but only when the appropriate combination of buttons are pressed. When the unit is off, pressing the key will turn it back on in the pause mode. Memory is not erased when the unit is turned off. When the unit is off, the battery drain is very low.

- PAUSE: Stop accumulating data. Only sound level is active. When key is pressed, pause time is displayed.

- RUN: Starts or continues accumulating data. Display shows run time. 
- RESET: Pressing both PAUSE and ON/OFF for $5 \mathrm{~s}$ will cause the unit to reset. After the unit has reset, a 0 or -..- (four dashes) will be displayed and the unit will be in the pause mode.

- BATTERY TEST: Press SOUND LEVEL and check the display for a single decimal point (e.g., 72.9). If additional colons and decimal points appear (e.g., :7:29), the battery is low and requires replacement. If the decimal points and colons are reversed after a day of use but had been normal at the start of the day, the readings are still good. The MICRO-14 is powered by a single $9-\mathrm{V}$ transistor battery with an $80-\mathrm{h}$ battery life. A low-battery indication is displayed $8 \mathrm{~h}$ before the end of the life of an alkaline battery.

- BATTERY REPLACEMENT: Loosen the 2 screws on the back of the unit and remove the back. Remove the battery from the cavity, and carefully unclip the battery. Replace with a new battery. Take care to observe the polarity of the battery, and do not reverse the terminals. For best results, use a $9 . \mathrm{V}$ alkaline battery. Replace the battery in the compartment, and check the display. If it displays four dashes, replace the back cover. If not, check the connections on the battery. The MICRO-14 is now operating in the pause mode.

NOTE: When the unit is off the battery still powers the memory. If the unit is not going to be used for a few days, the battery should be removed.

- SOUND LEVEL: The sound level, in decibels, at the end of each second, with slow (1 s) time constant. SOUND LEVEL is the only function active during pause time.

- MAXIMUM LEVEL: The maximum sound level, in decibels, with slow time constant.

- AVG LEVEL: The integrated average of the slow time constant sound level with a threshold. It is measured in decibels.

- PERCENT DOSE: The dose measured as a percentage of the allowable 8-h dose.

- RUN TIME: Length of time the unit has been in run mode.

- OL TIME: Length of time the unit has exceeded the overlimit level. The overlimit counter updates up to 16 times a second. Only complete seconds are displayed.

\section{READING DATA}

Pressing any key except ON/OFF will cause data to be displayed. The key must be held down for $1 \mathrm{~s}$ before it is read. If the key is held down, the data will be updated each second. When the key is released, the last displayed data will remain on the display. If the data cannot be calculated (as an example, AVG LEVEL cannot be calculated if the MICRO-14 has never been in the run mode), the ---- will be displayed. 
MARTIN MARIETTA

ENERGY SYSTEMS, INC.

Oak Ridge National Laboratory
Pollutant Assessments Group

Health and Safety

Procedures Manual
Sect. 18 Rev. 2

Date 6/92

Page 5 of 14

SUBJECT: QUEST ELECTRONICS MICRO-14 NOISE DOSIMETER

\subsubsection{Displayed Data}

- SOUND LEVEL: The current sound level in decibels.

- MAX LEVEL: The maximum level with a slow time constant.

- AVG LEVEL: The average integrated sound level with a threshold and an exchange rate integrated during run time in decibels. The threshold and exchange rate are set at the factory to agree with the label on the unit.

- PERCENT DOSE: The accumulated noise dose expressed as a percentage for all noise above the threshold.

- OL TIME: The time the noise level has been abnve the overlimit level. If the overlimit level has not been exceeded for a total of $1 \mathrm{~s}$, the OL TIME will read ":0". The overlimit level is set to $115 \mathrm{~dB}$.

- RUN TIME: The time the unit has been in the run mode and accumulating data. The time will be in minutes and seconds for the first hour; hours, minutes, and $1 / 10$ of a minute from 1 to $20 \mathrm{~h}$; and hours and minutes after $20 \mathrm{~h}$.

\subsubsection{Data Recording}

Record data on noise monitoring form (Fig. 18.1). Submit all field data forms to the SSHO and copies to the SPM.

\subsection{OFFICE CALIBRATION}

Because this instrument is microprocessor controlled, many of the adjustments are automatic or are factory set. There are only four internal adjustments to be made.

There are three switches inside the battery compartment under the flap. These will only be changed in the office by the electronics technician. The switches are used to select criterion level, exchange rate, and threshold. There is one field calibration screw on the face of the meter.

NOTE: If the switches are missing, the unit has been factory-set for the required criterion level, exchange rate, and threshold.

- The criterion level is set with the left-most switch (part of a dual switch).

- On sets $85 \mathrm{~dB}$. Off sets $90 \mathrm{~dB}$. OSHA requires a $90-\mathrm{dB}$ criterion level.

- The exchange rate is set with the center switch (the right part of the dual switch).

- On sets $3 \mathrm{~dB}$. Off sets $5 \mathrm{~dB}$. OSHA requires a 5-dB exchange rate.

- The threshold is set with the right-most switch (the single switch). 
MARTIN MARIETTA

ENERGY SYSTEMS, INC.

Oak Ridge National Laboratory
Pollutant Assessments Group

Health and Safety

Procedures Manual
Sect. 18 Rev. 2

Date $6 / 92$

Page 6 of 14

\section{SUBJECT: QUEST ELECTRONICS MICRO-14 NOISE DOSIMETER}

Sheet of

NOISE MONITORING FORY

Date. Project Subconeractor(s)

Techniclan's Name S1te Location

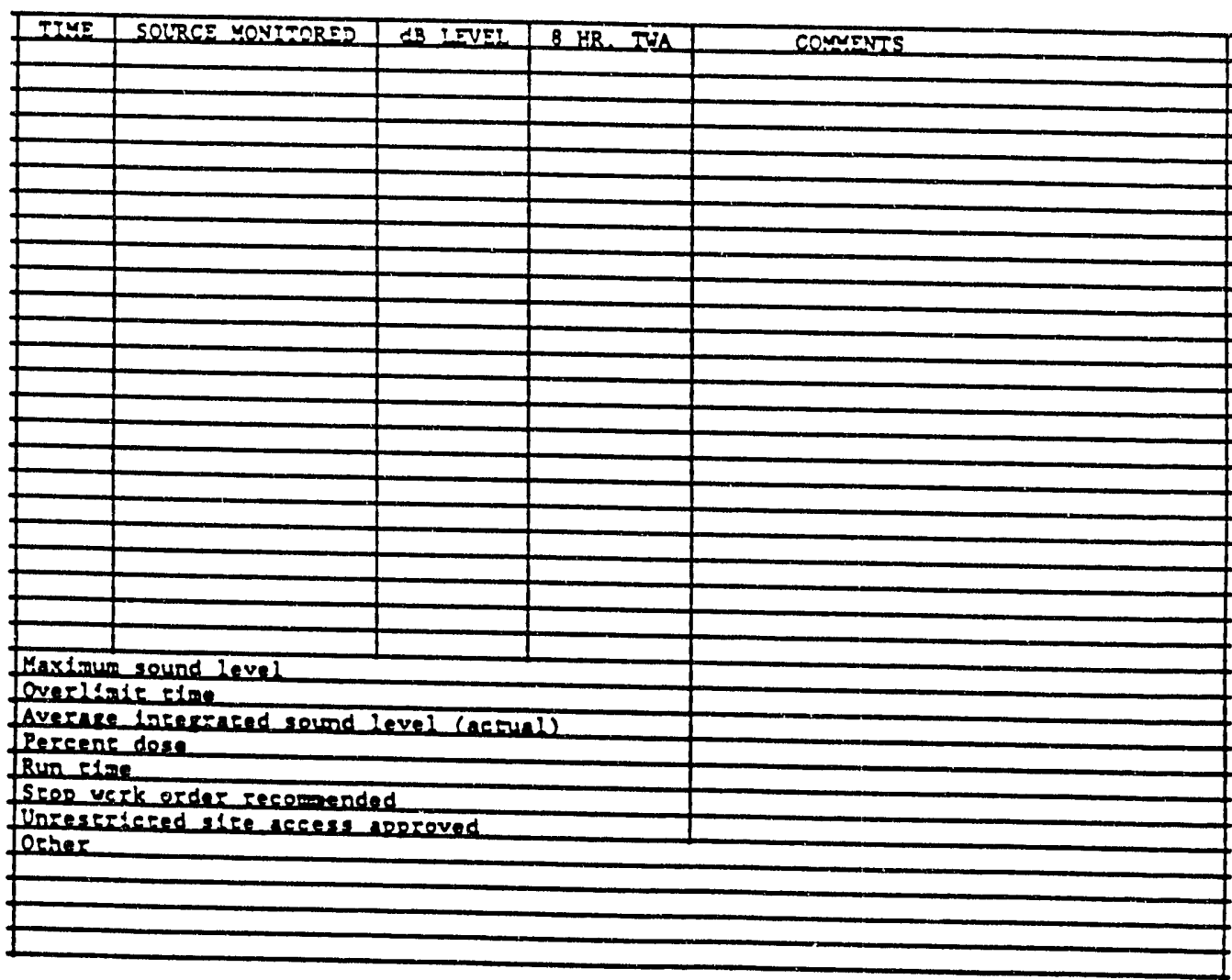

DLetribue10n: Projoce Kanager For Corrective Action: Projece Maneger

Subcontract Suparvisor

Projece Raneger

Dete

Subconerace Superv1sor

Dece

Fig. 18.1. Noise monitoring form. 
MARTIN MARIETTA

ENERGY SYSTEMS, INC.

Oak Ridge National Laboratory
Pollutant Assessments Group

Health and Safety

Procedures Manual
Sect. 18 Rev. 2

Date 6/92

Page 7 of 14

\section{SUBJECT: QUEST ELECTRONICS MICRO-14 NOISE DOSIMETER}

- On sets $80 \mathrm{~dB}$. Off sets $90 \mathrm{~dB}$. OSHA requires a 90 -dB threshold for engineering controls and an 80-dB threshold for hearing conservation. As an example, for hearing conservation, set both the dual switches to off and set the single switch to on.

- Consult the Quest Electronics factory if other criterion levels, exchange rates, or thresholds are required. The total available settings are as follows:

- Criterion level: ' $/ 0,84,85$, or $90 \mathrm{~dB}$.

- Exchange rate: $3,4,5$, or $6 \mathrm{~dB}$.

- Threshold: $70,75,80,85$, or $90 \mathrm{~dB}$.

To ensure consistently accurate operation, it is recommended that the unit be returned once a year to the manufacturer for a complete checkout and calibration. The calibration standards for the equipment in Quest's laboratory are traceable to the U.S. National Bureau of Standards.

\subsection{FIEID CALIBRATION}

The MICRO-14 will be checked daily before it is used. It is recommended that the Quest calibrators, such as the CA-12B Sound Level Calibrator, be used with the appropriate 8-mm microphone adaptor.

1. Turn MICRO-14 on, press SOUND LEVEL, and check to see if only one decimal point is on display. If two colons and a decimal point are displayed, the battery is low and should be replaced.

2. Turn on the calibrator, and check the battery indicator. Replace the battery if required. Set calibrator to $1000 \mathrm{~Hz}$ and $110 \mathrm{~dB}$. Hold calibrator 2 in. from your ear to check if the calibrator is producing a tone.

3. Remove the windscreen from the microphone, being careful not to damage it. Carefully insert the microphone in the coupler, and place the coupler in the calibrator. Make sure the microphone is inserted all the way in the coupler and that the coupler rests flush on the inner rim of the calibrator. Turn the calibrator on and hold down the SOUND LEVEL key on the MICRO-14. The MICRO-14 should display between 109.5 and $110.5 \mathrm{~dB}$. Atmospheric pressure has virtually no effect on the MICRO-14. However, calibrator sound levels are affected by altitude; if the MICRO-14 is calibrated at high altitudes, corrections must be made. For the Quest CA 12 calibrator, the correction is $-0.1 \mathrm{~dB}$ for each $2000 \mathrm{ft}$ above sea level. For example, at $6000 \mathrm{ft}$ the MICRO-14 should be calibrated to $109.7 \mathrm{~dB}$.

4. If the reading is off slightly, insert a small screwdriver in tive hole above CAL and slowly turn the adjustment screw while pressing the SOUND LEVEL key until the display reads $110.0 \mathrm{~dB}$. 


\section{SUBJECT: QUEST ELECTRONICS MICRO-14 NOISE DOSIMETER}

5. The MICRO-14 is now calibrated and ready for use.

6. If a calibrator is used at any frequency other than $1000 \mathrm{~Hz}$, the proper correction for that frequency weighting must be made.

7. Record the calibration data on the Noise Monitoring Form (Fig. 18.1).

8. Remove the microphone from the calibrator, and turn off the calibrator.

\subsection{OPERATING PROCEDURE}

1. If display is blank, press ON/OFF to turn unit on and wait until the SOUND LEVEL has stabilized before entering the RUN mode if data is to be collected and averaged with previous data taken, or

2. Clear the MICRO-14 memory by pressing and holding down both the ON/OFF key and the PAUSE key for $5 \mathrm{~s}$ until the display shows a single zero and a single colon.

3. If two decimal points and a colon are displayed, replace the battery and continue.

4. Check the calibration of the unit.

5. Record necessary calibration data in the office and/or field log book, including

- Date and time of entry.

- Site identification.

- Instrument, model number, and serial number.

- Calibrator used.

- Instrument calibration technician.

6. Attach the microphone to the collar of the operator, or it can be used as a hand-held instrument with the microphone mounted on the 58-863 microphone bracket. It may be either clipped to the bracket or the clip removed and the microphone screwed to the bracket. The bracket is then attached to the belt clip on the back of the instrument. If desired, the complete unit can be mounted on a tripod. The microphone should be pointed upward forming approximately a $70^{\circ}$ angle with the noise source. It should not be pointed at the noise source.

7. Press the RUN key.

8. Install the security cover and attach the unit to the operator's belt or pocket.

9. Remove the unit from the operator.

10. At the end of the workday, remove the security cover and press PAUSE.

11. Press each function key and record the results on the noise monitoring form (Fig. 18.1).

12. Press the ON/OFF key until the display becomes blank. If the unit is not going to be used for several days, remove the battery. 
MARTIN MARIETTA

ENERGY SYSTEMS, INC.

Oak Ridge National Laboratory
Pollutant Assessments Group

Health and Safety

Procedures Manual
Sect. 18 Rev. 2

Date $6 / 92$

Page 9 of 14

\section{SUBJECT: QUEST ELECTRONICS MICRO-14 NOISE DOSIMETER}

\subsubsection{Interpreting Results}

\subsubsection{Estimating TWA from AVG LEVEL}

A short-term sample can be used to estimate worker exposure even if the workday is other than $8 \mathrm{~h}$ by adding or subtracting a correction factor from the AVG LEVEL reading.

For example, if a worker has an AVG LEVEL of $85.50 \mathrm{~dB}$ after a 10-min sample, the sample is representative of the noise throughout the workday, and the workday at that position is 7:15 (duration at that time is $7 \mathrm{~h}$ and $15 \mathrm{~min}$ ), then from Table 18.1, "Corrections for computing 8-h TWA from short-term noise monitoring," under the OSHA $5 \mathrm{~dB}$ exchange rate find $-0.71 \mathrm{~dB}$, added to 85.50 to compute a TWA of $84.79 \mathrm{~dB}$. The correction factor is ER $\times \log 2$.

Table 18.1 Corrections for computing 8-h TWA from short-term noise monitoring

\begin{tabular}{cclll}
\hline Workday & \multicolumn{5}{c}{ Exchange rates } \\
\hline HR:MIN & $3.01 \mathrm{~dB}$ & \multicolumn{4}{c}{$4 \mathrm{~dB}$} & $5 \mathrm{~dB}$ & $6.02 \mathrm{~dB}$ \\
\hline $0: 30$ & -12.04 & -16 & -20 & -24.08 \\
$1: 00$ & -9.03 & -12 & -15 & -18.06 \\
$1: 30$ & -7.26 & -9.66 & -12.07 & -14.53 \\
$2: 00$ & -6.02 & -8 & -10 & -12.04 \\
$2: 30$ & -5.05 & -6.71 & -8.39 & -10.1 \\
$3: 00$ & -4.25 & -5.66 & -7.07 & -8.51 \\
$3: 30$ & -3.59 & -4.77 & -5.96 & -7.18 \\
$4: 00$ & -3.01 & -4 & -5 & -6.02 \\
$4: 15$ & -2.74 & -3.65 & -4.56 & -5.49 \\
$4: 30$ & -2.49 & -3.32 & -4.15 & -4.99 \\
$4: 45$ & -2.26 & -3 & -3.76 & -4.52 \\
$5: 00$ & -2.04 & -2.71 & -3.39 & -4.08 \\
$5: 15$ & -1.82 & -2.43 & -3.03 & -3.65 \\
$5: 30$ & -1.62 & -2.16 & -2.7 & -3.25 \\
$5: 45$ & -1.43 & -1.9 & -2.38 & -2.86 \\
$6: 00$ & -1.24 & -1.66 & -2.07 & -2.49 \\
$6: 15$ & -1.07 & -1.42 & -1.78 & -2.14 \\
$6: 30$ & -0.9 & -1.19 & -1.49 & -1.8 \\
$6: 45$ & -0.73 & -0.98 & -1.22 & -1.47 \\
& & & &
\end{tabular}


MARTIN MARIETTA

ENERGY SYSTEMS, INC.

Oak Ridge National Lahoratory
Pollutant Assessments Group

Health and Safety

Procedures Manual
Sect. 18 Rev. 2

Date 6/92

Page 10 of 14

SUBJECT: QUEST ELECTRONICS MICRO-14 NOISE DOSIMETER

Table 18.1 (continued)

\begin{tabular}{|c|c|c|c|c|}
\hline \multirow{2}{*}{$\frac{\text { Workday }}{\text { HR:MIN }}$} & \multicolumn{4}{|c|}{ Exchange rates } \\
\hline & $3.01 \mathrm{~dB}$ & $4 \mathrm{~dB}$ & $5 \mathrm{~dB}$ & $6.02 \mathrm{~dB}$ \\
\hline 7:00 & -0.57 & -0.77 & -0.96 & -1.15 \\
\hline $7: 15$ & -0.42 & -0.56 & -0.71 & -0.85 \\
\hline $7: 30$ & -0.28 & -0.37 & -0.46 & -0.56 \\
\hline $7: 45$ & -0.13 & -0.18 & -0.22 & -0.27 \\
\hline 8:00 & 0 & 0 & 0 & 0 \\
\hline $8: 15$ & 0.13 & 0.17 & 0.22 & 0.26 \\
\hline $8: 30$ & 0.26 & 0.34 & 0.43 & 0.52 \\
\hline $8: 45$ & 0.38 & 0.51 & 0.64 & 0.77 \\
\hline 9:00 & 0.51 & 0.67 & 0.84 & 1.02 \\
\hline 9:15 & 0.63 & 0.83 & 1.04 & 1.26 \\
\hline 9:30 & 0.74 & 0.99 & 1.23 & 1.49 \\
\hline $9: 45$ & 0.85 & 1.14 & 1.42 & 1.71 \\
\hline $10: 00$ & 0.96 & 1.28 & 1.6 & 1.93 \\
\hline $10: 15$ & 1.07 & 1.43 & 1.78 & 2.15 \\
\hline $10: 30$ & 1.18 & 1.56 & 1.96 & 2.36 \\
\hline $10: 45$ & 1.28 & 1.7 & 2.13 & 2.56 \\
\hline $11: 00$ & 1.38 & 1.83 & 2.29 & 2.76 \\
\hline 11:15 & 1.48 & 1.96 & 2.45 & 2.96 \\
\hline $11: 30$ & 1.57 & 2.09 & 2.61 & 3.15 \\
\hline $11: 45$ & 1.66 & 2.21 & 2.77 & 3.33 \\
\hline $12: 00$ & 1.76 & 2.33 & 2.92 & 3.52 \\
\hline $12: 30$ & 1.93 & 2.57 & 3.21 & 3.87 \\
\hline $13: 00$ & 2.1 & 2.8 & 3.5 & 4.21 \\
\hline $13: 30$ & 2.27 & 3.01 & 3.77 & 4.54 \\
\hline $14: 00$ & 2.43 & 3.22 & 4.03 & 4.86 \\
\hline $14: 30$ & 2.58 & 3.43 & 4.28 & 5.16 \\
\hline $15: 00$ & 2.73 & 3.62 & 4.53 & 5.16 \\
\hline $15: 30$ & 2.87 & 3.81 & 4.77 & 5.74 \\
\hline $16: 00$ & 3.01 & 4 & 5 & 6.02 \\
\hline
\end{tabular}


MARTIN MARIETTA ENERGY SYSTEMS, INC.

Oak Ridge National Laboratory
Pollutant Assessments Group

Health and Safety

Procedures Manual
Sect. 18 Rev. 2

Date 6/92

Page 11 of 14

\section{SUBJECT: QUEST ELECTRONICS MICRO-14 NOISE DOSIMETER}

\subsubsection{Continuous or intermittent}

The sound level shall be determined by a sound-level meter, conforming at a minimum to the requirements of the American National Standard Specification for Sound Level Meters, S1.4 (1971) Type S2A and set to use the A-weighted network with slow meter response. Duration of exposure shall not exceed that shown in Table 18.2.

Table 18.2 Threshold limit values for noise

\begin{tabular}{cc}
\hline $\begin{array}{c}\text { Duration per day } \\
\text { (h) }\end{array}$ & $\begin{array}{c}\text { Sound level } \\
(\mathrm{dBA})^{a}\end{array}$ \\
\hline 16 & 80 \\
8 & 85 \\
4 & 90 \\
2 & 95 \\
1 & 100 \\
$1 / 2$ & 105 \\
$1 / 4$ & 110 \\
$1 / 8$ & $115^{b}$ \\
\hline
\end{tabular}

"Sound levels in decibels are measured on a sound level meter, conforming at a minimum to the requirements of the American National Standard Specification for Sound Level Meters, S1.4 (1971) Type S2A, and set to use the A-weighted network with slow meter response.

${ }^{b}$ Continuous or intermittent exposure in excess of $115 \mathrm{dBA}$ should not be permitted.

These values apply to total duration of exposure per working day, regardless of whether it is one continuous exposure or a number of short-term exposures, and does include the impact and impulsive type of noise that contributes to the sound-level meter reading at slow response.

When the daily noise exposure is composed of two or more periods of noise exposure of different levels, their combined effect should be considered, rather than the individual effect of each. If the sum of the following fractions: 


$$
\frac{C_{1}}{T_{1}}+\frac{C_{2}}{T_{2}}+\ldots \frac{C_{n}}{T_{n}}
$$

exceeds unity, then, the mixed exposure should be considered to exceed the threshold limit value, $C_{1}$ indicates the total duration of exposure at a specific noise level, and $T_{1}$ indicates the total duration of exposure permitted at that level. All on-the-job noise exposures of $80 \mathrm{~dB}$ or greater shall be used in these calculations. No instantaneous impact noise levels shall exceed $140 \mathrm{~dB}$.

\subsubsection{Considerations of Measurement and Accuracy}

An integrating meter such as the MICRO-14 Noise Dosimeter has the ability to integrate all continuous, intermittent, and impulsive sound levels within the range of the instrument. This avoids many of the potential errors created by attempting to read and correctly interpolate sound level meters in fluctuating sound fields. However, it is important to use correctly and to understand the limits of any instrument to achieve its maximum accuracy.

Threshold discontinuity can cause notable differences in readings on various meters if the noise level is near the unit's threshold. Because the instrument assumes that noise even slightly below the threshold is absolutely quiet, that noise level is not accumulated. This is most noticeable in the readings of dose if the threshold is the same as the criterion level.

Peak noise levels greater than the range of the instrument are "clipped" and act as if they were at the maximum level of $146 \mathrm{~dB}$.

Crest factor is an almost meaningless term for instruments whose crest factors exceed $30 \mathrm{~dB}$. The MICRO-14 is capable of measuring pulses as short as $1 \mathrm{~ms}$, with a peak amplitude of $143 \mathrm{~dB}$ and a background level of $80 \mathrm{~dB}$. This is a pulse range of $63 \mathrm{~dB}$. The crest factor would depend on how often this pulse occurred but could be greater than $60 \mathrm{~dB}$.

\subsection{EFFECTS OF OPERATOR PRESENCE}

Any object or surface can act as a reflector or absorber of sound. An operator or person wearing the dosimeter is also a reflector or absorber of sound and affects the microphone performance. The MICRO-14 is designed to read correctly with the microphone in a random incidence sound field, without the presence of reflecting objects. 
MARTIN MARIETTA ENERGY SYSTEMS, INC.

Oak Ridge National Laboratory
Pollutant Assessments Group

Health and Safety

Procedures Manual
Sect. 18 Rev. 2

Date 6/92

Page 13 of 14

\section{SUBJECT: QUEST ELECTRONICS MICRO-14 NOISE DOSIMETER}

The recommended placement of the microphone for personal noise monitoring is on the shirt collar, high on the shoulder, and away from the neck as far as practical; the best placement for the microphone is the middle of the shoulder. If the noise is directional, it is generally best to place the microphone near the ear that receives the most noise exposure.

\subsubsection{Use with Windscneen}

To prevent wind from blowing across the microphone and causing erroneous measurements, the Model WS-5 windscreen should be used. It is recommended that the windscreen be used at all times. In addition to wind protection, the windscreen helps to support the microphone in an upright position and protects it from dust and oily and humid conditions. The windscreen is made of reticulated polyurethane foam. The acoustical attenuation is small and can generally be neglected. Attenuation is approximately $0.5 \mathrm{~dB}$ at $8 \mathrm{KHz}, 0.25 \mathrm{~dB}$ at $4 \mathrm{KHz}$, and 0 at frequencies below $2.5 \mathrm{KHz}$.

\subsubsection{Internal Electrical Noise}

The internal electrical noise of the MICRO-14 is equivalent to an acoustical level of approximately $40 \mathrm{~dB}$. This is $30 \mathrm{~dB}$ or more below the threshold and $10 \mathrm{~dB}$ below the minimum sound level and has little effect on the readings.

\subsubsection{Accuracy of Readings}

There is a tendency to overestimate the accuracy of digital readings. In the MICRO-14, some values such as AVG LEVEL are computed to $0.01 \mathrm{~dB}$. The absolute accuracy of the reading is not $0.01 \mathrm{~dB}$. (See specifications for accuracy and tolerances.) However, the resolution of $0.01 \mathrm{~dB}$ is useful in determining the sampling time required for a short-term sample. As an example, if AVG LEVEL reading is increasing $0.03 \mathrm{~dB}$ every second, additional sampling time may be required. If the reading remains stable within a few hundredths of a decibel, the sample time may be long enough.

NOTE: The MICRO-14 is in the pause mode after the battery is replaced, the instrument is turned on or reset, or the pause key is pressed. Wait until the SOUND LEVEL has stabilized before entering the run mode.

Always remember to press RUN. 
MARTIN MARIETTA

ENERGY SYSTEMS, INC.

Oak Ridge National Laboratory
Pollutant Assessments Group

Health and Safety

Procedures Manual
Sect. 18 Rev. 2

Date 6/92

Page 14 of 14

\section{SUBJECT: QUEST ELECTRONICS MICRO-14 NOISE DOSIMETER}

\subsection{REFERENCES}

ANSI S1.4, 1983.

ANSI S1.25, 1978.

Code of Federal Regulations-29, Pt. 1900-1910, 1990.

Code of Federal Regulations-29, Pt. 1910.95, 1990. Table G-16a.

Code of Federal Regulations-30, Pt. 1-199, 1988.

EPA. 1981. Health and safety requirements for employees engaged in field activities. Environmental Protection Agency Order 1440.1. U.S. Environmental Protection Agency, July 12, 1981.

NIOSH. 1985. Occupational safety and health guidance manual for hazardous waste site activities. National Institute for Occupational Safety and Health, Occupational Safety and Health Administration, U.S. Coast Guard, and Environmental Protection Agency, DHHS (NIOSH) Publication 85-115, October 1985. 


\section{INTERNAL DISTRIBUTION (GRAND JUNCTION)}

1. S. M. Berkoff

2. W. H. Burke

3. N. G. Conklin

4. J. R. Davidson

5. K. S. Dickerson

6. P. V. Egidi

7. D. B. Ertel

8. M. L. Espegren

9. D. S. Foster

10. F. G. Gardner

11. C. L. Gist

12. D. K. Halford

13. S. C. Hall

14. K. A. Hebbard

15. M. K. Jensen

16. A. R. Jones

17. P. M. Kearl
18. R. R. Knott

19. N. E. Korte

20. B. J. Krall

21. A. D. Laase

22. R. P. Lenc

23. N. F. Lewis

24. D. S. List

25. C. A Little

26. D. A. Locke

27. D. C. Marty

28. S. K. Mather

29. L. M. McDowell-Boyer

30. C. A Muhr

31. M. E. Mumby

32. S. M. Murray

33. J. E. Peterson

34. D. A. Pickering

\section{INTERNAL DISTRIBUTION (OAK RIDGE)}

35. B. A Berven

36. L. S. Corrill

37. S. V. Kaye

38. D. C. Landguth

39. R. A. Mathis

40. P. S. Rohwer

41. R. L. Siegrist
42. R. E. Swaja

43. P. F. Tiner

44. J. K Williams

45. Central Research Library

46-47. Laboratory Records Department

48. Laboratory Records, ORNL-RC

49. ORNL Patent Section

\section{EXTERNAL DISTRIBUTION}

50. Office of Assistant Manager for Energy Research and Development, Oak Ridge Field Office, P.O. Box 2001, U.S. Department of Energy, Oak Ridge, TN 37831-8600

51. W. L. Beck, Oak Ridge Associated Universities, P.O. Box 117, Oak Ridge, TN 37831-0117

52. D. E. Brown, Senior Environmental Protection Specialist, Allied-Signal, Inc., 200 E. 95th St., Kansas City, MO 64131

53. T. J. Harvey, Office of Technical Services, H \& R Technical Associates, 12800 Middlebrook Rd., Suite 207, Germantown, MD 20874

54. P. Keary, U. S. Department of Energy, Kansas City Area Office, 2000 E. 95th St., Kansas Ciry, MO 64131

55. D. N. Mackenzie, Office of Technical Services, H \& R Technical Associates, 12800 Middlebrook Rd., Suite 207, Germantown, MD 20874

56. D. Robertson, HAZWRAP, P.O. Box 2003, Oak Ridge, TN 37831-7606

57. B. Stanley, HAZWRAP, P.O. Box 2003, Oak Ridge, TN 37831-7606

58. M. Wade, HAZWRAP, P.O. Box 2003, Oak Ridge, TN $37831-7606$

59. Office of Scientific and Technical Information, P.O. Box u2, Oak Ridge, TN 37831 

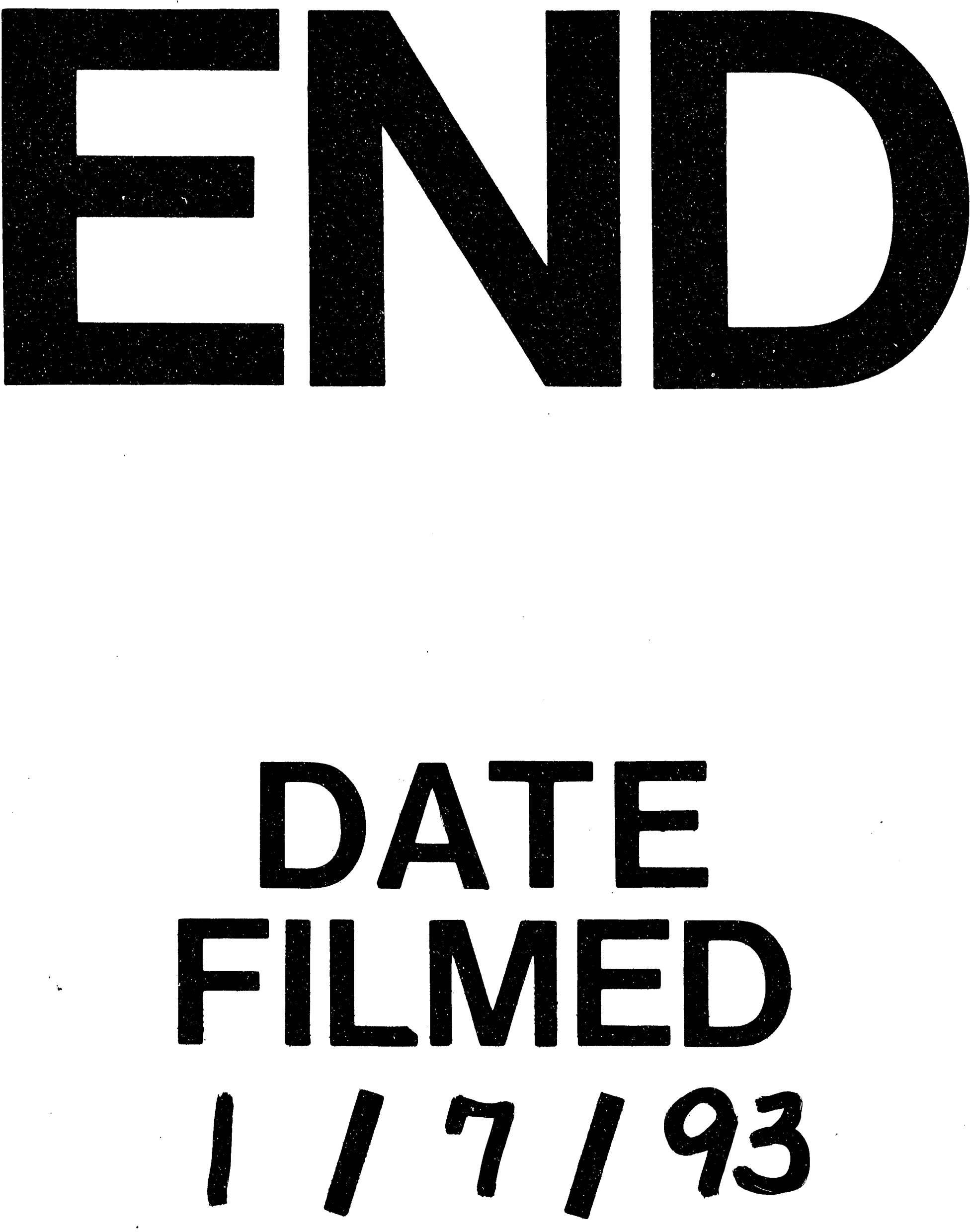
